KATHOLIEKE UNIVERSITEIT TE LEUVEN

Fakulteit Sociale Wetenschappen

Departement Politieke Wetenschappen

\title{
SCHAALVERGROTING EN BESTUURSKRACHT
}

\author{
EEN BELEIDSANALYTISCHE BENADERING VAN DE \\ HERSTRUKTURERING VAN DE LOKALE BESTUREN
}

VOLUME II

Promotor: Prof. Dr. P. VAN DE MEERSSCHE

\author{
Proefschrift \\ tot het bekomen van de graad van \\ Doctor in de Sociale Wetenschappen \\ aangeboden door \\ Frank DELMARTINO \\ Licentiaat in de Politieke \\ en Sociale Wetenschappen
}


Hoofds tuk $V$ - DOELEINDEN - ONDERZOEK

$\S 1$. De relevantie van doeleinden-onderzoek bij de beleidsanalyse

"Improving public policymaking is a lengthy
and difficult process, but a feasible one"

Y. Dror (1)

\subsection{POLITIEK EN BELEID}

"Voor de realisatie van haar doeleinden is de politiek aangewezen op het beleid" (2). Ideaaltypisch zou men beleid dan ook kunnen opvatten als een uitvoerende instantie t.a.v. het politieke beslissingsmoment. In werkelijkheid moeten er ook bij de besluituitvoering voortdurend beslissingen worden genomen, zodat politiek en beleid nauw samenhangen en elkaar wederzijds beïnloeden. "Beide staan in direkt verband met de doeleinden-middelen hiërarchie, waarbij in de meest elementaire vorm de politiek de doeleinden kiest en het beleid, daarop gebaseerd, de middelen" (3). Ook hier is een doorgedreven dichotomie echter onvruchtbaar. Politieke diskussies fixeren zich immers niet enkel aan de top van de doeleindenhiërarchie, maar horen al evenzeer thuis bij de operationalisering van deze doeleinden in konkrete taakstellingen. Een voortdurend samenspel van doelstellende en uitvoerende momenten, van politiek en beleid levert dan ook een model op dat meer aangrijpingspunten biedt. Vandaar dat bij een empirische onderzoeksbenadering de term 'beleid' steeds meer als een integrerend begrip gehanteerd wordt

(1) In : Public policymaking reexamined. Scranton - Pennsylvania, 1968, p. 304.

(2) D. VAN HOUTEN, Toekomstplanning. Planning als veranderingsstrategie in de welvaartsstaat. Meppel, 1974 , p. 45.

(3) Ibidem, p. 45. 
voor een "samenstel van min of meer algemene doelen, eventueel gekombi neerd met de wegen waarlangs men de doelen wil bereiken, de middelen die men wil aanwenden ter verwerkelijking van de doelen, en de tijdstippen waarop de verwerkelijking moet plaatsvinden" (1). Beleid veronder-stelt dus systematische besluitvorming, planning. Men kan dan ook spreken van een proces van beleidsvorming (2). Met Hoogerwerf zullen we onder beleid dan ook verstaan : "een min of meer overwogen streven bepaalde doeleinden met bepaalde middelen en in een bepaalde cijdsvolgorde te bereiken" (3).

Het 'doel' komt uit deze definitie als een centraal element van het beleid naar voor (4). Het is zelfs een van de kenmerken van elke organisatie (5). Een doel verwijst echter ook naar een actor die het doel nastreeft. Kuypers spreekt in dit verband van een "toekomstige situatie... die de actor in een gegeven uitgangssituatie beoogt, of althans accepteert als gewenst, en waarvan hij het intreden meent te kunnen bevorderen of teweegbrengen" (6). Deze actor treedt in de regel niet op als individu maar participeert an een besluitvormingsproces in groeps- of organisatieverband. Niettemin zullen persoonlijke en organisatorische doeleinden vaak interfereren, mede omwille van de waarden die erin verweven liggen. "Menselijke besluitvorming blijft ook in de grote samenleving en binnen omvangrijke organisaties een normatieve bezigheid... Normen, zedelijke normen van algemene betekenis, maar ook meer konkrete politieke maatstaven zijn bij de probleemstelling en de keuze van groot belang, omdat de objektieve situatie een soms brede marge van keuze laat... De doelstellingen van het bestuur zijn t.o.v. de normen en maatstaven niet autonoom, mar zijn het gemeenschappelijk produkt van een simultaanproces van oordeelsvorming en feitelijke vastscel-

(1) H. VAN RULLER, Agglomeratie-problematiek in Nederland; $p=10$.

(2) Ibidem, p. 10 .

(3) A. HOOGERWERF, De analyse van de beleidsinhoud, in : Beleid belicht, I, p. 84.

(4) H.J. AOUINA, Beleidsanalyse in de politicologie, in : Beleid belicht, I, $\mathrm{p} .43$.

(5) H. VAN RULLER, Op. cit., p. 33.

(6) G. KUYPERS, Grondbegrippen van politiek. Utrecht, 1973, p. 30. 
ling van de omstandigheden en mogelijkheden" (1).

Verschillende auteurs hebben gepoogd dit overgangsgebied tussen de toetsbare bestuurlijke criteria en de waardeoordelen die achter het gevoerde beleid opduiken in beeld te brengen. Dwight Waldo spreekt van een pyramide van waarden, waardoor de strenge scheiding tussen politiek en administratie vervangen wordt door een organische wisse1werking. Aan de ene kant ziet hij een zone van wetenschap, waar objektiviteit mogelijk is en efficiency gemeten kan worden ; aan de andere kant een $z i c h$ verwijdend referentiekader met toenemende kontroversemogelijkheid over de na te streven doeleinden (2). Van Duyne drukt het nog plastischer uit met het beeld van een doeleinden-plant, waarvan de wortel de fundamentele doelstelling is van de mens waartoe alle meer gedifferentieerde doeleinden zich laten herleiden.

Vertaald naar de sfeer van het lokaal bestuur, kan men eenzelfde spanningsveld vaststellen tussen de waardegeladen politieke programma's waarmee kandidaat-mandatarissen zich voorstellen en op basis waarvan een aantal van hen een bestuursmandaat van de kiezers verkrijgen, en de feitelijke situatie en mogelijkheden van de gemeente waarbinnen dit programma waargemaakt moet worden. Het gemeentelijk beleid zal erin bestaan beide polen van het spanningsveld op elkaar af te stemmen en nader tot elkaar te brengen. Daartoe dienen ze echter eerst geëxpliciteerd te worden resp. als (uiteindelijke) doelstellingen en (meer onmiddellijke) taakstellingen, en moeten ook de tussenliggende schakels - de middelen - ontwikkeld worden.

\subsection{DE DOELEINDEN-MIDDELEN HIERARCHIE}

Het onderscheid tussen doeleinden en middelen is meestal niet in abstrakte termen aan te geven. Niet enkel zijn doeleinden van een bepaald ab-

(1) H.A. BRASZ, Openbaar bestuur in een democratie, in : Democratie anno 1967. Werking en feilen van een systeem. Meppel, 1967, p. 89.

(2) D. WALDO, The Administrative State. New York, 1948, p. 205.

(3) D. VAN DUYNE, Prospectief bestuur. Arnhem, 1964, p. 12. 
straktieniveau op hun beurt middelen t.a.v. 'verder' gelegen doeleindea, maar bovendien wordt dit onderscheid medebepaald door de 'sociaal-kulturele setting' (1). Zo is er in de welvaartsstat sprake van depolitizering of ontideologisering, doordat het overheidsbeleid zich beperkt tot het feitelijk realiseren van reeds gekozen doeleinden. "De funktie van de utopie als dynamisch toekomstperspektief ontbreekt ; van een samengesteld geheel van doeleinden kan nauwelijks worden gesproken... Vandaar een steeds pragmatischer opstelling van de politieke partijen, met alle inkonsistenties vandien" (2). Van Houten konstateert dan ook een ruime belangstelling voor taakstellingen en middelen, waarbij gestreefd wordt naar het formuleren en hanteren van overzichtelijke en kwantificeerbare eenheden, terwijl de vraag naar het 'waartoe' op de achtergrond verdwijnt. "Er wordt wel eens een politieke vraag gesteld, maar deze heeft veelal betrekking op de efficiëntie en volledigheid van het middel" (3).

A1 lijkt deze formulering tamelijk extreem gesteld (4), toch kan ze sensibiliserend werken m.b.t. de diskrepantie tussen de feitelijke beleidsvorming en een ideaaltypische benadering. Het opbouwen van een hiërarchisch doeleinden-middelen model zal dan ook steeds heuristisch (5) en voorlopig van aard zijn. De samenhang zal slechts gepercipieerd kunnen worden vanuit een globale beleidsbenadering en slechts vatbaar zijn voor interpretatie tegen de achtergrond vaneen bepaald politico-maatschappelijk klimaat.

(1) P. THOENES, Ideologie en utopie, in : A. HOOGERWERF (red.), Verkenningen in de politiek II. Alphen a.d. Rijn, 1971, pp. 154-155.

(2.) D. VAN HOUTEN, Op. Cit., p. 49.

(3) Ibidem, p. 50 .

(4) Vgl. met het 'incrementalistische' model van beleidsopbouw, besproken in volgende paragraaf 1.3 .

(5) BRASZ preciseert in 'Democratie anno 1967' : "In een ingewikkelde situatie is het nauwkeurig vaststellen van de doelstellingen en van de ter verwerkelijking van deze doelstellingen beschikbare alternatieve aktiviteiten, een nooit ophoudend gekompliceerd proces dat veel lijkt op wetenschappelijke research. Daarom zijn grote delen van het proces van besluitvorming toegankelijk voor wetenschappelijk onderzoek" - pp. 88-89. 
Dit hiërarchisch model, dat we verder met Van Duyne een doeleindenstruktuur noemen (1), heeft als hoofdopdracht de doeleinden, middelen en taakstellingen derwijze met elkaar in relatie te brengen dat een beter inzicht in het beleid mogelijk wordt. Deze verheldering kan o.i. zowel de beleidsformulering als de beleidsevaluatie ten goede komen, doordat de explicitatie van de samenstellende delen de doelgerichtheid en koherentie van de gehele beleidsopbouw aan een kritische toetsing onderwerpt. Doeleinden en middelen dienen dus nader gespecifieerd te worden in funktie van hun positie in de beleidsopbouw. In de literatuur zijn verschillende indelingen voorgesteld waaraan telkens een hele terminologie beantwoordt. Van Duyne spreekt over een fundamentele doelstelling en een aantal basis-doeleinden, waaronder telkens sub-doelstellingen aangeduid kunnen worden. Het zijn de 'gemeenschappelijke samenlevingsdoelstellingen' waartegenover de 'bestuursdoeleinden' de middelen vormen. Bestuursdoeleinden kunnen op hun beurt gedifferentieerd worden naargelang de korte of lange termijn waarop ze berekend zijn. "Hoe korter en hoe beperkter de doelstelling is, hoe scherper zij kan worden geformuleerd en hoe gemakkelijker het bestuursproces kan worden gevoerd" (2).

Een vergelijkbare benadering is deze van Young, die een onderscheid maakt tussen 'goals' en 'objectives' (3). Een goal is een "value to be sought after, not an object to be achieved". Van Houtem spreekt in dit verband van 'richtdoelen' en 'objektdoelen' (4). Het ene is een ideaal dat in abstrakte termen uitgedrukt wordt, het andere een konkreet doel, bereikbaar en meetbaar. Gekombineerd met het onderscheid door Myrdal tussen 'goals' en 'targets' (5), krijgen we een hanteerbare driedeling : richtdoelen, objektdoelen en taakstellingen.

De Nederlandse Commissie voor de ontwikkeling van Beleidsanalyse (C.O.B.A.) tenslotte onderscheidt hoofddoelstelling, subdoelstellingen en enkelvou-

(1) Op. cit., p. 11 .

(2) D. VAN DUYNE, Op. cit., p. 89.

(3) R.C. YouNG, Goals and goalsetting, in : Journal of the American Institute of Planners, maart 1966, p. 78 - Geciteerd bij D. VAN HOUTEN, p。 48 .

(4) D. VAN HOUTEN, op. cit., p. 48.

(5) G. MYRDAL, The theoretical assumptions of social planning, in : Transactions of the fourth world congress of sociology, 1959, p. 155. 
dige doelstellingen ( 1 ), waarbij het duidelijk wordt dat niet zozeer de naamgeving belangrijk is als wel een kontinue operationalisering van boven naar beneden. Dit lijkt ons ten andere ook de taak te zijn van de analyse van de doeleindenstruktuur in het kader van een globale beleidsanalyse : het 'algemene' moet in verband gebracht worden met het 'bijzondere', de meest fundamentele doelstelling met de feitelijke taakstelling van het 'dagelijks bestuur'. De indeling en de nomenklatuur die we hierbij zullen hanteren, komen ter sprake bij de toelichting van het konkrete onderzoeksontwerp (2). Belangrijker lijkt ons hier de principiële vraag of de bij een beleidsanalyse te volgen weg wel integraal deze is van de 'verbijzondering' van doeleinden naar taakstellingew. Het gaat hierbij niet enkel om een methodologische vraag, maar veeleer over het gehanteerde koncept van beleidsvorming.

\subsection{RATIONALISME EN INCREMENTALISME}

Een volledig rationeel proces van beleidsvorming zou ongeveer als volgt verlopen :

1. Het opstellen van een komplete set van doeleinden in volgorde van belangrijkheid.

2. Het inventariseren van mogelijke middelen.

3. Het berekenen van alle kosten en baten van alle middelen.

4. Het vergelijken van deze kosten en baten met de gestelde doeleinden.

5. Het kiezen van die middelen welke de hoogste netto-baten op zullen leveren (3).

Dit zg. synopiisch model van beleidsvorming gaat er van uit dat de beleidsvoerders een duidelijk inzicht verworven hebben in de probleemsituatie, de doeleinden scherp omlijnd hebben en onbeperkt over de nodige middelen kunnen beschikken. Géén van deze drie vooronderstellingen gaat in de werkelijkheid echter op.

(1) Beleidsanalyse, nr. 3 (s.d.) Geciteerd bij D. VAN HOUTEN, p. 48.

(2) Cfr. $\$ 2.4 .:$ Opboww van de doeleindenstruktuur.

(3) Ontleend aan H.A. MARCH en J.G. SIMON, Organizations, New York, 1958 , p. 136 - Bewerkt door H.J. AQUINA, Op. cit., p. 44. 
In een alternatief model dat hij 'disjointed incrementalism' noemt, vertrekt Lindblom daarentegen van de feitelijke moeilijkheden die verbonden zijn aan de identifikatie en de formulering van de problemen, de specificering van de doeleinden en het onderscheid tussen doeleinden en middelen (1). "De wijze waarop een situatie gepercipieerd wordt, kan medebepalend zijn voor de inhoud van het uiteindelijk te voeren beleid" (2). Gezien de - de facto - beperkte mogelijkheden om alle konsekwenties van het beleid te overzien, geschiedt de beleidsvorming slechts 'incremental'. Waarden, doeleinden en middelen zijn zo dooreengeweven dat er voor een rationeel proces amper ruimte overblijft. De strategie van het incrementalisme bestaat uit acht elementen die met elkaar samenhangen :

1. Men neemt marginale beslissingen t.a.v. het status quo.

2. Men beschouwt slechts een beperkt aantal alternatieven, en deze alternatieven bevatten slechts marginale wijzigingen t.a.v. het status quo.

3. Van elk alternatief beschouwt men slechts een beperkt aantal effekten.

4. Men past doeleinden aan bij de gegeven middelen.

5. Problemen worden (her) geformuleerd tijdens de beleidsvorming.

6. Analyse en evaluatie geschieden stap voor stap.

7. Analyse en evaluatie zijn gericht op het wegnemen van een als ongewenst ervaren situatie, en niet zozeer op het bereiken van een voorafgesteld doel.

8. Analyse en evaluatie worden door alle betrokkenen ondernomen, wat inhoudt dat het proces van incrementalisme gefragmenteerd ('disjointed') verloopt (3).

Een doeleindenkonsistentie is in Lindblom's model niet vereist voor de beleidsvorming. De doelen dienen zelfs niet geëxpliciteerd te worden en nog minder geabstraheerd. Er treedt veeleer een 'mutual adjustment' op, een koördinatie van het beleid zonder dat er sprake is van een ko-

(1) Ch. E. LINDBLOM, The policymaking process, Englewood Cliffs, 1968.

(2) H.J. AQUINA, op. cit., p. 44.

(3) Ibidem, p. 45. 
ordinatie van het beleid zonder dat er sprake is van een koördinator, een gemeenschappelijk doel of regels die de wederzijdse betrekkingen vastleggen (1). Zulk mutual adjustment is dan ook 'partisan', partijdig. "In een 'advocacy process' komen alle belanghebbenden op voor de eigen waarden en belangen, zodat het beleid inzicht krijgt in de diverse implikaties van haar ingrijpen en daarop gebaseerd tot een strategie kan komen. Het gevolg is dat de besluiten... steeds een gematigd karakter hebben en zich t.a.v. de doeleinden-middelen hiërarchie zullen beperken tot taakstellingen en wat daaronder ligt. Over doelen wordt niet gesproken; ieder moet maar zien hoe hij de geëffektueerde middelen optimaal kan aanwenden ter realisatie van de eigen doelein$\operatorname{den}^{\prime \prime}(2)$.

Deze interpretatie van Van Houten, warin een afwijzing doorklinkt, lijkt ons te scherp geformuleerd. Terecht kan gesteld worden dat het incrementele model het politieke karakter van het beleid onvoldoende in reliëf brengt, waardoor de kans op technokratisering groter wordt. Bovendien houdt het 'advocacy process' het risico in dat niet alle bevolkingskategorieën in de samenleving evengoed aan hun trekken zullen komen. Ingrijpende matschappelijke veranderingen gebaseerd op een kreatief toekomstdenken mag men in geen geval van de steeds 'marginale' beslissingen verwachten.

Daarentegen biedtLindblom's model het voordeel nauw aan te sluiten bij de werkelijke besluitvorming in de westerse demokratieën (3) en een aangrijpingspunt te bieden aan de beleidsvoerders m.b.t. een geleidelijk systematischer beleidsvorming. Mag men inderdaad van de beleidsverantwoordelijken verwachten dat zij steeds de (bestuurlijke) problematiek in al haar facetten analyseren? Lindblom beperkt de analyse tot een overzichtelijk aantal niet te gekompliceerde faktoren en stelt zich hierdoor op een meer haalbaar uitgangspunt. Nochtans lijkt Lindblom's alternatief ons méér te zijn dan een pragmatisch standpunt t.a.v. een optimaal theoretisch model. De besluitvormingstheorieën hangen o.i.

(1) D. VAN HOUTEN, Op. cit., pp. 53-54.

(2) Ibidem, p. 54.

(3) Cfr. de diagnose door D. VAN HOUTEN, besproken in $\S 1.2$. 
nauw samen met een konceptie van en een ontwikkelingsperspektief voor de welvaartsstaat (1) of de verzorgingsstaat (2).

Binnen het bestek van dit proefschrift kan niet nader ingegaan worden op de normatieve besluitvormingstheorieën of de systeemanalytische benaderingen. Het is nochtans niet zonder belang aan te stippen dat een aantal hedendaagse auteurs de rationele en incrementele modellen nader tot elkaar willen brengen. Zo zal Etzioni stellen dat "most incremental decisions specify or anticipate fundamental decisions, ... and the cumulative value of the incremental decisions is greatly affected by the underlying fundamental decisions" (3). Twee mechanismen zijn dan ook vereist bij een "aktieve benadering" :

"1. a high-order, fundamental policymaking process which sets basic directions ;

2. an incremental process which prepares for fundamental decisions and revises them after they have been reached".

ook Dror tracht te komen tot een kombinatie van beide modellen in wat hij een "prescriptive-preferable model" noemt, d.i. "a model which fits reality while being directed towards its improvement, and which can in fact be applied to policymaking while motivating a maximum effort to arrive at better policy" (4).

Ofschoon de besluitvorming op het lokale vlak ongetwijfeld minder vèrreikend en komplex is dan op het nationale niveau, kan ze o.i. toch zinvol benaderd worden vanuit de hoger aangehaalde theorievorming en methodische handreikingen. Op mikro-schaal staan de lokale beleidsvoerders immers voor een enigszins vergelijkbare veelheid van mogelijke opgaven en taakstellingen, terwijl ook voor hen de komplexiteit van de achterliggende problematiek een nauwkeurige omlijning van doelstellingen niet eenvoudig makkt. De marge waarbinnen reële beleidsbeslissingen

(1) D. VAN HOUTEN, Op. cit.

(2) P. VAN DAALEN, Bestuur voor mensen. Besluitvorming in de verzorgingsstaat. Meppe1, 1973. Vooral de pp. 101-130 : De verzorgingsstaat opnieuw bezien.

(3) A. ETZIONI, The active society ; a theory of societal and political processes. New York, 1968, pp. 282-304.

(4) Y. DROR, Ventures in policysciences : concepts and applications. New York, 1971, pp. 257-263. 
genomen kunnen worden is weliswaar beperkt, maar de matschappelijke problematiek waarmee ze gekonfronteerd worden is een staalkaart van de werkelijkheid die ook op nationaal vlak aan de orde is.

Hoe dan ook, lokaal bestuur veronderstelt beleidsbeslissingen, en ook hier kunnen deze slechts genomen worden in een spanningsveld tussen beperkte mogelijkheden en brede doelstellingen. Met onze poging beide polen met elkaar te konfronteren via het expliciteren van de tussenschakels, hopen we het feitelijk gevoerde beleid te verhelderen in zijn krachtlijnen en oriëntaties. De beleidsanalyse zal vanzelfsprekend niet enkel de taakstellingen toetsen aan a priori geformuleerde doeleinden, maar al evenzeer een verduidelijking nastreven van de doelstellingen die het beleid impliciet inhoudt. Zelden immers kan men bij de analyse fundamentele beslissingen aanwijzen waarvan de implikaties in één totaalblik te vatten zijn. Meestal gaat het om fragmentaire benaderingen, 'marginale beslissingen' (Lindblom), met onduidelijke samenhang en konsistentie. We zien het juist als de opgave van de doeleindenanalyse in deze niet steeds rationele beleidsopbouw toch de wezenlijke kentrekken te onderscheiden. In de belangstellingssfeer van dit proefschrift zullen we bovendien uit de doeleindenschema's in de stad-ommeland kontekst, indikaties pogen af te leiden m.b.t. hun onderling samenspel. Het feitelijk gevoerde beleid in agglomeratieverband zal aldus kunnen bijdragen tot een genuanceerd standpunt $i . v \cdot m$. een mogelijke bestuurlijke schaalanpassing en -geleding.

$\S 2$. Opzet en uitwerking van het onderzoek

\subsection{BELEIDSANALYSE IN EEN KONTEKST VAN SCHAALVERGROTING}

Zoals het evaluatieonderzoek van enkele reeds samengevoegde gemeenten, is ook de doeleindenanalyse in dit proefschrift in sterke mate toegespitst op de problematiek van de bestuurskracht in een kontekst van (mogelijke) schalverruiming. Deze focus is niet alleen vanzelfsprekend in het kader van dit onderzoek, maar lijkt ons ook optimaal als toets voor de relevantie en de mogelijkheden van deze vorm van beleids- 
analyse.

Veel sterker nog dan het evaluatieonderzoek veronderstelt een analyse van de beleidsdoeleinden immers een loyale en gemotiveerde medewerking vanwege de beleidsvoerders (1). Hoezeer hun verklaringen, interpretaties en intenties ook getoetst worden aan een naukeurige verkenning van het feitenmateriaal en gerelativeerd worden door de ervaringen en de standpunten van de administratie en de politieke oppositie, toch blijft de visie van de feitelijke politieke verantwoordelijken het kernstuk en het sluitstuk van een inhoudelijke beleidsanalyse. In de sfeer van het lokale bestuur houdt dit in dat men met het kollege van burgemeester en schepenen (inklusief de gemeentesekretaris) een dialoog kan aangaan over de essentiële kentrekken van het gevoerde beleid, en men tevens toegang krijgt tot deze gemeentelijke diensten en dokumenten die de verklaringen kunnen staven, expliciteren of ontkrachten.

$\mathrm{Nu}$ is het niet zozeer de toegankelijkheid of de gespreksbereidheid van de mandatarissen en de diensten die het hoofdprobleem vormt, als wel de inhoud van de dialoog. Tussen beleidsvoerders en onderzoeker moet in een spiraalvormig proces een inzicht groeien i.v.m. de globale samenhang en de innerlijke konsistentie van opties en doelstellingen. Zulk gesprek overstijgt in ruime mate de vraag - antwoord dialoog. op puur akademische enquêtevragen krijgt men in het beste geval even eenzijdige antwoorden. Wil men echter doordringen tot de politieke motivering van de beleidskeuze, dan moet men inspelen op de vragen die impliciet of meer expliciet bij de beleidsvoerders zelf leven. Het is dan niet meer de onderzoeker alléen die kritische vragen stelt en de politicus die ze probeert toe te dekken. Politici en onderzoeker gaan zich samen vragen stellen over expliciete en impliciete prioriteiten, over rationele en irrationele motieven, over causale verbanden en de onderlinge wisselwerking van opties, middelen en doeleinden.

Om deze - optimaal geschetste - gespreksbereidheid en -attitude te benaderen, moeten natuurlijk een aantal voorwaarden aanwezig zijn :

(1) We zouden hen ook de beleidsverantwoordelijken kunnen noemen, maar willen met de bredere term 'beleidsvoerders' alle personen aanduiden die een reëel impakt hebben op de besluitvorming in dit verband. 
a. Allerbelangrijkst is we1 de materie, of althans het aanknopingspunt voor het gesprek. Lokale mandatarissen zullen slechts gemotiveerd participeren aan dergelijke dialoog indien de relevantie ervan voor de hand ligt. De schaalvergrotingsproblematiek lijkt wel uitstekend aan die voorwaarde te voldoen. Grote en kleine lokale besturen worden gekonfronteerd met de vraag naar de optimale bestuursgeleding voor de toekomst. De konsekwenties hieruit zijn dermate ingrijpend voor het voortbestaan van de eigen gemeente en de verlenging van het eigen mandaat, dat geen enkele mandataris deze vraag als 'akademisch' van de hand kan doen. In dit klimaat krijgt een onderzoek naar de beleidsdoeleinden een kans in de mate dat het kan bijdragen om van binnen uit de wezenskentrekken van de gemeente en het gemeentelijk beleid in het licht te stellen, en aldus een element toe te voegen aan het 'dossier' van de bestuurlijke herstrukturering.

b. Het gesprek met de beleidsvoerders moet dan ook aansluiten bij deze belangstellingssfeer en inspelen op deze verwachtingen. Dit kan optimal in het kader van een multi-disciplinair herstruktureringsonderzoek op vraag van de betrokken gemeenten zelf. Voortbouwend op de gegevens uit de deelprojekten kan de analyse van de doeleindenstruktuur het sluitstuk vormen. Wanneer het initiatief echter niet uitgaat van de betrokkenen maar opgezet is door de voogdij-overheid (Provinciebestuur, Ministerie van Binnenlandse Zaken) kan de onderzoeker wel beschikken over het feitenmateriaal maar ontmoet hij weerstanden bij de lokale besturen om deze gegevens te gaan interpreteren. Het is dank zij de participatie van de eigen organisatie van de gemeenten (de Vereniging van Belgische Steden en Gemeenten : V.B.S.G.) aan deze onderzoeksprojekten, dat het inzicht groeit bij de gemeentebesturen dat zij er alle belang bij hebben de beleidsdynamiek ter sprake te brengen bij de kritische doorlichting van hun ruimtelijke situering, funktionele uitrusting en taakprofiel.

De onderzoeker die een analyse van de doeleindenstruktuur op het oog heeft kan dan ook bezwarlijk geisoleerd optreden. De insertie in een onderzoeksteam bezorgt hem niet alleen een introduktie bij de besturen, maar vooral een referentiekader en een data-ondersteuning. Ten aanzien van besturen die helemal niet $b i j$ een breed herstruktureringsonderzoek betrokken zijn, kan hij slechts een analyse van de doeleindenstruktuur doorvoeren indien hij geruggesteund wordt door een bona fide-instelling 
of organisatie. In de delikate kontekst van de schalvergroting die nog grotendeels gekenmerkt wordt door een klimaat van argwaan en onzekerheid, is het niet de provinciale of centrale overheid die de beste introduktie kan bieden voor een intern onderzoek. Ook de universiteit en het wetenschappelijk onderzoek in het algemeen krijgen niet het volle krediet van de gemeentemandatarissen, indien de relevantie van het onderzoek en de operationele bruikbaarheid van de resultaten niet mede gegarandeerd worden door een organisatie die hun vertrouwen geniet. In casu ligt het dan ook voor de hand als geisoleerd universitair onderzoeker samen te werken met de V.B.S.G., minstens wat de introduktie betreft en zoveel mogelijk ook i.v.m. de informatieverzameling.

c. Een derde voorwaarde voor een zinvolle analyse van de doeleindenstruktuur is wel het format van de te onderzoeken gemeente. Een nauwkeurig minimum-criterium is moeilijk aan te halen, omdat de drempel waarboven men als bestuur geacht wordt beleidsdoeleinden te formuleren, verschuift in funktie van de ruimtelijke situering van de gemeente. Een eerder kleine gemeente in het spanningsveld van een regionaal centrum kan bv. zinvol onderzocht worden in een globale kontekst, terwijl heel wat gemeenten van gelijkaardige omvang doch in een niet-gepolarizeerd gebied gelegen, wellicht vanwege de beperkte mogelijkheden en een weinig gedifferentieerde taakperceptie nog niet aan een doeleindenstruktuur toe zijn. De selektie van de gemeenten zal dan ook niet uitsluitend gebaseerd kunnen worden op hun omvang, maar zal al evenzeer rekening moeten houden met hun 'strategische' ligging.

\subsection{SELEKTIE VAN DE TEST-CASES}

\subsubsection{Representativiteit van het agglomeratie-onderzoek}

Bij de selektie van de test-cases voor deze analyse van de doeleindenstruktuur moet men enerzijds rekening houden met de beperkende voorwaarden die eigen zijn aan het genre (cfr. supra), en anderzijds uitgaan van de meest relevante probleemsituaties die zich in ons land voordoen. De onderzoeker kan m.a.w. niet op eigen krachten en buiten het kader van een breed onderzoeksprojekt om, een willekeurig staal van gemeenten op indringende wijze analyseren. De projekten waaraan hij wel kan par- 
ticiperen spitsen zich anderzijds niet noodzakelijk toe op een representatief onderzoeksgeheel. Wil men dus de bestuurskracht van de gemeenten in een kontekst van schalvergroting op een zinvolle wijze belichten vanuit een inhoudelijke bespreking van de beleidsdoeleinden, dan zal men voortbouwend op de onderzoeksgegevens die in projektverband verkregen werden de analyse op eigen krachten moeten uitbreiden. De bedoeling zit hierbij voor, een beperkt staal van gemeenten samen te stellen dat in hoge mate representatief is voor de problematiek van de schalvergroting.

De representativiteit kan hier nochtans niet even breed en veelzijdig zijn als bij de evaluatie van de fusiegemeenten. Juist uit dit onderzoek is immers de geringe relevantie naar voor gekomen van vragen naar de toegenomen beleidsmogelijkheden van gemeenten die zich ook na de fusie beperken tot de traditionele bestuurstaken. Al kon de korrelatie niet getoetst worden tussen het format van de gemeente en het feitelijk opzetten van een systematisch beleid, toch ligt het voor de hand dat juist de kleinere gemeenten hiervoor een geringere marge overhouden. En zelfs wanneer hier bepaalde beleidsopties aan te wijzen zijn, worden ze door hun partieel karakter irrelevant in vergelijkend perspektief.

Dit ligt anders voor deze kleinere gemeenten die vanuit hun situering in de invloedssfeer van een centrum, met een slechts partieel uitgebouwde doeleindenstruktuur kunnen inspelen op de beleidsprioriteiten van de stad. Een analyse van centrum en rand is zelfs in meer dan één opzicht interessant. Allereerst kan hieruit afgeleid worden welke funkties vanuit het centrum expliciet of stilzwijgend afgestoten of afgevloeid zijn naar alle of naar bepaalde randgemeenten. Omgekeerd rekent de rand erop dat het centrum een aantal taken blijft verzorgen die het eigen bestuurlijke territorium overschrijden, en waarvan de lasten niet - of niet billijk - gespreid worden. Een analyse van de doeleindenstruktuur van centrum en randgemeenten kan dit welbekend verschijnsel in de bestuurlijke agglomeratieproblematiek in deze zin preciseren, dat gepoogd wordt een koherent beeld op te hangen van de effektief genomen beleidsopties in het licht van geëxpliciteerde doeleinden. Hieruit komen dan de taken in reliëf die in elk van de betrokken gemeenten prioritaire aandacht krijgen, maar ook deze die men niet behartigt omdat ze (voorals- 
nog) geen plaats (kunnen) krijgen in het beeld dat gegroeid is i.v.m. het opdrachtenreliëf van stad en rand. Het hoeft geen betoog dat deze beeldvorming nauw samenhangt met de konkrete sociaal-ruimtelijke situering, de historische groei, de institutionele kontekst, de financiële armslag en wellicht nog andere omgevingsfaktoren. Het kan echter boeiend zijn ook het impakt van de visie en de dynamiek van een bestuursploeg op de gemeentelijke taakvervulling te verrekenen.

Kan dus een analyse van de doeleindenstruktuur zinvol doorgevoerd worden in elke gemeente die aan beleidsformulering toe is, dan zijn de resultaten toch op de eerste plaats relevant naar de bestuurlijke herstrukturering toe in de kontekst van een agglomeratie-onderzoek. Het is immers vooral in dit verband dat de interaktie van de taakprofielen van centrumstad, kleine en grote randgemeenten indikaties kan opleveren voor de bestuurlijke geleding. Indien men er inderdaad van uitgaat dat niet a priori en noodzakelijkerwijze alle bestuurstaken binnen de agglomeratie in de toekomst op één enkel niveau behartigd moeten worden (een globale fusie dus), maar dat minstens het alternatief onderzocht dient te worden van een geleed agglomeratiebestuur, dan dringt een genuanceerde analyse van de huidige taakperceptie en -behartiging zich op. Hieruit kunnen konklusies resulteren i.v.m. de 'schaalgevoeligheid' van sommige taken ("op welk niveau wordt een bepaalde taak optimaal behartigd ?"), maar ook i.v.m. de omschrijving van de agglomeratie zelf. Het niet aansluiten bij of inspelen op de stedelijke doeleindenstruktuur kan $n 1$. indikatief zijn voor de verschillende opstelling en oriëntering van een randgemeente. Vooral in dit laatste geval kan een beleidsanalyse dan ook aanwijzingen opleveren voor het al dan niet aanhechten van deze gemeente bij het stedelijk kerngebied.

Indien we op grond van intern-methodische motieven de agglomeratieproblematiek weerhouden hebben als meest aangewezen testgebied i.v.m. de relevantie van de doeleindenstruktuur voor de bestuurlijke schalvergroting, dan kunnen er ook externe argumenten aangehaald worden die deze keuze nog sterker motiveren.

a. De agglomeratieproblematiek staat in het brandpunt van de wetenschappelijke belangstelling. Met name de sociaal-geografen, planologen, ekonomisten en bestuurskundigen hebben de veelzijdige interaktie binnen de stad-ommeland relatie in het licht gesteld en er een begrippenkader 
voor gekreëerd (1).

b. De regionale steden hebben van hun kant het initiatief genomen om de specifieke situatie van de centrum-stad aan de orde te stellen. In een studie die de 15 Belgische regionale steden in vergelijkend perspektief analyseert, wordt een aktueel overzicht gegeven van de zware lasten en verplichtingen die deze centrum-funktie inhoudt (2).

$c$. In een aantal gevallen habben regering en wergever de studie var het agglomeratieverschijnsel niet afgewacht om in een schaalvergrctende zin te interveniëren. Oudenaarde en Tongeren, maar vooral Brugge en Bergen zijn hiervan markante voorbeelden. Het ziet er nar uit dat bij de komende systematische herindeling de grote en kleinere agglomeraties nog sterker op de voorgrond zuilen treden (3). De vraag naar de optimaie besturilike geleding in agglomeratieverband is dus wel aktueel.

\subsubsection{Selektie van de aggiomeraties}

De selektie van de te onderzoeken agglomeraties werd in een eerste faze georiënteerd door een aanbod. Acht gemeenten ten Westen van Kortrijk vroegen in 1972 aan de Vereniging van Belgische Steden en Gemeenten een wetenschappelijk gefundeerd dossier samen te stellen met het oog op een gemotiveerde stellingname in het herstruktureringsdebat. Zowel de eigen funktionele uitrusting en beleidsrealisaties zouden hierbij ter sprake moeten komen als de relatie tot de regionale centrumstad Kortrijk. Aangezien er bij de gemeentebesturen in kwestie een grote bereidheid bestond om aktief bij te dragen tot de dossiervorming, waren de voorwaarden aanwezig om bij wijze van experiment de analyse van de doeleindenstruktuur ce introduceren. De gesprekken met de schepenkolleges vonden plaats in

(1) Enkel ten exemplatieve titel kunnen we hier verwijzen naax een paar werken, die meer uitvoerig in hoofdstuk II, $\$ 2$ ter sprake kwameal :

- GOOSSENS, M., Hiërarchie en hinterlanden der centra; een methodologische studie toegepast op Noordoost-België. Acta Geographica Lovaniensia nr. 2. Leuven, 963.

- Bours, A., Sociale geografie, stadsgewestvorming en gemeenteijike indeling. In : BOURS en LAMBOOY, Stad en stadsgewest in de ruimtelijke orde. Assen, 1970.

- VAN RULlER, H., Aggloneratieproblematiek in Nederland. Alphen aan de Rijn, 1972。

(2) Onderzoek 'Regionale steden en steden in expansie'. Onuitgegeven rapport. Brussel, 1973.

(3) Cfr. hoofdstuk III, $\$ 2$. : het herstruktureringsbeleid. 
november 1972, terwijl in het voorjaar 1973 een gezamenlijke bespreking werd gewijd aan de krachtlijnen die uit de acht deelonderzoeken naar voor kwamen.

Deze analyse van de westelijke stadsrand moest nu gekonfronteerd worden met de doeleindenstruktuur van Kortrijk zelf. Hier miste de onderzoeker de introduktie en de data-ruggesteun van een multidisciplinair projekt. Het stadsbestury van Kortrijk werd evenwel medio 1/3 bereid gevonden tot een aantai gesprekken en stelde bovendien alles in het werk om de nodige achtergrondinformatie te bezorgen.

De selektie van de randgemeenten gebeurde in casu dus op een eerder toevallige basis. De representativiteit van de onderzoeksresultaten wordt o.i. hierdoor niet aangetast, mits men het partiële karakter van de benadering niet uit het oog verliest. Een analyse van alle randgemeenten was binnen het bestek van deze studie niet mogelijk en wellicht ook niet aangewezen. Uiteindelijk was het ons niet te doen om een afgeronde verkenning van het Kortrijkse stadsgewest met het oog op uitgewerkte herstruktureringsvoorstellen. Veeleer werd éen type van agglomeratiesituatie partieel geanalyseerd om het te konfronteren met een andere konstellatie in de stad-rand verhouding, en aldus een eerste zicht te krijgen op een aantal fundamentele kentrekken van de beleidsformulering in agglomeratieverband.

Zoals in de survey van het Kortrijkse stadsgewest (1) aangetoond zal worden, vormen de acht gemeenten aan de westelijke rand inderdaad een specifiek type, een specifieke 'figuir' in het spanningsveld stad-ommeland. Ten dele sluiten ze immers morfologisch aan bij de stadskern, ten dele liggen ze gespreid over het stadsgewest. Ondanks de onderlinge relaties en de verschillende graad van verstedelijking die de differentiatie binnen de groep nog verhogen, is het gemeenschappelijk kenmerk vooral de gerichtheid op het regionale centrum. Op Wevelgem na horen al deze gemeenten ook cot de bescheiden groottekategorieén. Als tweede test-case moest daarom uitgekeken worden naar een regionale stad, enigszins vergelijkbaar met Kortrijk, waar net een verschiliend type van randgemeenten. Bij deze selektie bestond een voorkeur voor

(1) Cfr. infra $\$ 3.1$. 
een nederlandstalig regional cenckun, niet enkel om taalkundige redenen, maar vooral omwille van de vergelijkbaarheid van de opties in de sociokulturele beleidssfeer. De (eventueel) verschiliende benaderingswijze in beide raalgemeenschappen zol $\mathrm{n} 1$. storend kumen optreden. van de ache regionale centra in Viaanderen die nog in aanmerking kwarnen (1), moest Bruzge bovendien onmiddelijk uilgesloten worden na de fusie per 1 januari 1911.

Her bxiterium dat unteindelijk doursiaggevend moest aijn, had - zoals gezegd - betrekking op de 'tiguir" van de te onderzoeken randgemeencen. zonder zich hierbij op een uicgewerkte typologie te kunnen baseren, lag her voor de hand in dit alternatief monel woor de West-Kortrijkse konstellatie eerder de andachi te richten op esu grote randgemeente die zonder mogelijke betwisting tot de stedelijke agglomeratie hoort. Bovendien kon het relevant zijn ook een middelgrote randgemeente te analyseren warvan de betrokkenheid bij de agglomeratie vaststat, zonder er nochtans morfologisch bij aan te sluiten. Op deze wijze konden de meest voorkonende situaties in de agglomeratieproblematiek in het geheel van deze analyse van de doeleindenstrukcuur ter sprake komen.

Eemaal deze criteria bepald, stelde de definitieve selektie geen problemen meer. Enkel de Lauvense aggloneratie heeft immers randgemeenten var dit type aan te bleten, nl. eirerijds Kessel-Lo en Heveriee, anderzijds Herent en Wilsele. Welke van deze randgemeenten nu best weerhou den merden vow esi analyse in konfrontatie net de stad leuvens was daacentegen aiet zonder mer duidelijk.

Herent kwam vookal in anmerking omd it in de vourbereidende scudies met: her oug op de besciuilijke herstriktukering verschillende standpunten nat vour hwamen i.V.m. het al. Jat nlet betrekken van deze gemeente bij de fusie Groot-Lelven (2). Deze kontroverse was ecn vruchtbar berrein om in dialoog te treden det de Herentse beleidsverantwordijjken.

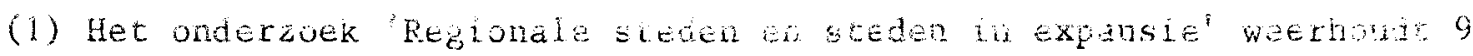
regionale steder in Vladederen: MecheIen, lomout, Tenven, Bruge, Kortrijk, Oostende, Aalst, St. Nikltas en Hasselt.

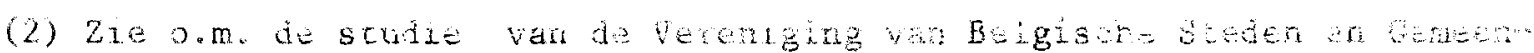

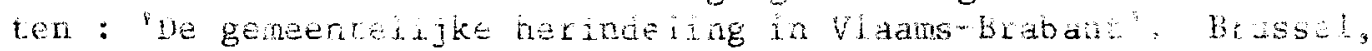
me $1973, \mathrm{pP}, 103-111$. 
De keuze tussen Heverlee en Kessel-Lo was moeilijker, omdat beide gemeenten als het ware geënt zijn op de centrum-stad. Uiteindelijk leek Kesse1-Lo de meest zinvolle test-case. Deze gemeente vertoont $n 1$. een grotere differentiatie inzake woon-, tewerkstelling-, kommerciële en rekreatieve funkties ( 1 ). Hier zowel als te Herent, maar ook in Leuven zelf, konden de gesprekken in een optimaal klimaat van openheid doorgaan en kreeg de onderzoeker alle ruggesteun wat het verzamelen van het feitennaterial betreft.

De hypothese waarvan bij de start van deze analyse werd uitgegaan (2), $\mathrm{n} 1$. de bereidheid van de kolleges van burgeneester en schepenen om in een kontekst van schalvergroting een kritische dialoog aan te gaan rond de eigen beleidsopties en uiteindelijk prioriteiten, vond dus wel degelijk bevestiging.

\subsection{AANDACHTSPUNTEN BIJ DE ANALYSE}

\subsubsection{Criteria}

Het was van meet af an duidelijk dat niet het geheel van het beleid in de verschillende testgemeenten voor analyse in aanmerking kon komen. Deze restriktie werd niet enkel ingegeven door de feitelijke beperkingen die de onderzoeker zich in het kader van dit proefschrift moest opleggen. $B i j$ het opsporen van relevant toetsings- en vergelijkingsmateriaal voor de schaalvergrotingsproblematiek in agglomeratieverband, zou iedere poging tot volledigheid in de zin van een exhaustieve inventarisatie van beleidsopties het doel van het onderzoek voorbijschieten. Gepoogd wordt immers enkele beleidssferen die bijzonder indikatief zijn voor de bestuurskracht van de gemeente en bovendien als 'schaal-gevoelig' gekwalificeerd kunnen worden, dusdanig in reliëf te brengen dat ze bij vergelijking met gelijkaardige analyses relevante informatie kunnen opleveren voor de bestuurlijke taakopvatting en -vervulling in het stad-rand spanningsve $1 \mathrm{~d}$.

(1) Cfr. infra, bij de survey van het Leuvens stadsgewest $: \S 4.1$.

(2) Cfr. supra, $\$ 2.1$. 
Aangezien de bestuurskracht in dit proefschrift vooral getoetst wordt aan aspekten als beleidsvisie en beleidsmogelijkheden, $z a l$ de analyse van de doeleindenstruktuur bij voorkeur deze beleidssferen weerhouden die indikaties kunnen opleveren voor de specifieke approach in elke tescgemeente afzonderlijk. De behartiging van een belangrijke taak als deze van brandpreventie en -bestrijding b.v., kan zwaar doorwegen op de begroting van een centrum-stad maar hoort niet meer thuis in een doeleindenanalyse sinds de centrale overheid in deze materie nationale normen opgelegd heeft.

Gaat onze belangstelling in dit verband dus hoofdzakelijk naar de 'vrije" sektor, deze van de niet stringent-genormeerde beleidstaken, en is ons onderzoek uiceindelijk gericht op de innoveringskracht die elk bestuur kan opleveren, dan is toch ook de oriëntatie belangrijk die deze innovatie uitgaat. Met name in her samenspel met de andere besturen in agglomeratieverband zullen we trachten deze taken te detekteren die verwijzen naar een mogelijke behartiging op een ander niveau dan het huidige. Meestal gaat het hierbij om een verschuiving in schaalvergrotende zin. Van een aantal taken staat het sinds de wet van 26 juli 1971 op de agglomeraties en de federaties van gemeenten immers vast dat ze in aanmerking komen voor behartiging op supra-kommunaal niveau (1). Schaalgevoeilig zijn echter ook deze beleidstaken en beleidssferen die zich lenen tot een (partiële) schaalverkleining, bv. via een formule van binnengemeentelijke decentralisatie in het kader van een grote entiteit. Het lijkt ons dan ook onverantwoord a priori elke schaalverandexing als een noodzakelijke schaalvergroting te interpreteren. Vandaar een begrip als 'schaalgevoeligheid' als uitgangspunt voor de te selekteren beleidssferen. Het is slechts op basis van de onderzoeksresultaten dat de hypothese van een mogelijke dubbele verschuiving al dan niet bevestiga kan worden.

\subsubsection{Beleidssfeer en deeltaken}

Men kan de overheidstaak op het lokale vlak in talrijke deeltaken opsplitsen nargelang de gekozen invalshoek. Ben eerder kwancitatief gerichte benadering kan bv. de feitelijke prestaties var elike runkionaris

(1) Art. 4, de paragrafen 2 en 3. Ofr. Hoofdstuk III, \$2.1.4 
analyseren en van hieruit berekenen wat elke deeltaak aan man/uren kost. In grotere gemeenten levert dit een vrij getrouw profiel op van de taakbehartiging (1). Meestal echter kan een onderzoeksteam zich dergelijke detaillering niet veroorloven of is zulke benadering zelfs irrelevant in funktie van het doel van de analyse. Een aantal aspekten van de interne bestuurskracht komen hierdoor wel aan het licht, met name de doelmatigheid van de personeelsorganisatie, maar niet meteen de grote beleidsopties. Meestal gaar er immers jaren over heen eer een beleidsheroriëntatie ten volle te detekteren is an de hand van de personeelsprestaties.

De indeling van de overheidstaken kan dan ook moeilijk gebeuren op basis van ter plaatse empirisch vastgestelde gegevens. Mede omwille van de vergelijkbaarheid van de resultaten is de onderzoeker aangewezen op een algemene indeling, die hij nochtans kritisch kan hanteren en aanpassen aan de specifieke invalshoek van zijn projekt. In België ligt het voor de hand uit te gaan van de funktioneel-ekonomische indeling, waarnaar alle gemeentebegrotingen sinds het dienstjaar 1969 opgemaakt zijn (2). Al gaat het hier niet om een taakindaling in de eigenlijke zin, toch biedt deze uniforme klassifikatie van de begrotingsposten een relevant zicht op het absolute en relatieve belang van de verschillende taakfacetten. De gegevens per begrotingsfunktie zullen dan ook vooral gehanteerd worden om de trends binnen de eigen gemeente te illustreren, en meer nog, om de al dan niet gelijklopende tendenzen in andere gemeenten te onderzoeken.

Naar de doeleindenstruktuur toe zal echter een meer inhoudelijke indeling ontworpen moeten worden, door elementen uit verschillende funkties te kombineren of bepaalde ruime funkties op te splitsen. Een beleidsanalyse veronderstelt immers een elementair zicht op de samenhang van een aantal taakeenheden. De onderzoeker vertrekt dan ook van de werkhypothese dat bepaalde deeltaken tot een meer globale beleidssfeer horen.

(1) Baanbrekend werk werd in dit verband verricht door een team bestuurskundigen van de Vrije Universiteit te Ansterdam, onder de dagelijkse leiding van drs. R.C.E. Kapteyn : Stadsgewest Oostelijk Mijngebied Bestuurlijke organisatie - Heerlen, 1970.

(2) Ministeriële omzendbrief van het Ministerie van Binnenlandse Zaken, dd. 25.10.1968, nr. B.C. 1969. Belg. Stb1. 5.11.1968. 
Slechts in zulke kontekst kunnen de verschillende opties zinvol gesitueerd worden in funktie van onmiddellijke of uiteindelijke doeleinden. In tegenstelling tot een indeling die gebaseerd is op de feitelijke prestaties van het overheidspersoneel of op de relatieve belangrijkheid van de uitgavenposten, zal deze analyse dus eerder de aandacht richten op de verschillende uitzichten van het gevoerde beleid en hierbij de samerhang en onderlinge wisselwerking in het licht stellen.

\subsubsection{Weerhouden beleidssferen}

Een indeling van de lokale overheidstaak in cermen van doeleinden, vertrekt meestal van de fundamentele opsplitsing in taken met een ordenend karakter en taken met een verzorgingskarakter. Tot de taken die hoofdzakelijk een ordenend karakter vertonen rekent mein het ruimtelijk beleid, de volkshuisvesting, de ekonomische aangelegenheden (werkgelegenheid, middenstand, landbouw) de rekreatie, de milieuhygiëne en het verkeer. Eerder verzorgend zijn dan taken als onderwijs, sociale zorg, kulturele zorg, sport, volksgezondheid, operbare veiligheid, vuilverwerking, openbaar vervoer, energievoorziening, enz. Ook een derde kategorie van taken kan in aanmerking genomen worden, $n 1$. deze met een hulpkarakter, in de mate althans dat men op het lokale niveau reeds aan informatieverwerking en onderzoek toe is (1).

Andere indelingscriteria zijn natuurlijk denkbaar. Hoogerwerf onderscheidt er een aantal, alleen al m.b.t. de beleidsdoeleinden (2). Het betreft hier echter beleidstypen in de politikologische zin, eerder geschikt voor een interpretatie van de onderzoeksresultaten dan als selektiecriteria voor de beleidssferen die uiteindelijk voor de analyse van de doeleindenstrukturur noten weerhouden worden.

Uit de ordenende en verzorgende taken dienen inderdaad enkele beieidstaken geselekteerd te worden die in hun sameribang indikaties oplevere. voor de bestiurskracht en het optimaal miveau van behártiging. Bij de

(1) Deze inmiddels klassiek geworden opdeling vindt men ook terug in herstruktureringsonderzoeken, zo bv, in het : Besiaursonderzoek Oost-Nedarland (kö̈rdinator: drs. J.N. Breunese). Enschede, 1973, p. 57 .

(2) A. HOOGERWER, De analyse van de beleidsinnoud, In : Beleid belint, pp. 93-95. 
eerder ordenende taken ligt de beleidssfeer van de ruimtelijke ordening (in de breedste betekenis van het woord) hierbij meteen voor de hand. Ruimtelijke ordening is zowat de kern-taak geworden van het lokaal bestuur, in deze zin dat "mits het vaststellen van het ruimtelijk plan beleidsvormende fazen plaatsvinden op het gebied van vrijwel alle overheidstaken" (1). "De overheidstaak ruimtelijke ordening heeft dan ook een overkoepelend karakter" (2). Men kan zelfs spreken van 'comprehensiveness ${ }^{p}$ (3). Van Ruller zal dan ook aan de hand van een analyse van de besluitvorming inzake het 'stedebouwkundig' beleid, relevante konklusies trekken voor het geheel van de centrumstad - randgemeente problematiek (4). Ook in België staat deze beleidssfeer centraal bij de bevoegdheden die bij agglomeratie- en federatievorming overgedragen worden (5). Het niveau waarop deze taak behartigd wordt, zal zelfs in belangrijke mate bepalend zijn voor het zwaartepunt in de besluitvorming in de brede lokale bestuurssfeer (kommunaal en supra-kommunal) (6).

Het ruimtelijk beleid als 'sleutel'-beleidssfeer moet dan ook in al zijn aspekten bij deze analyse van de gemeentelijke doeleindenstruktuur betrokken worden. Allereerst slaat dit natuurlijk op de officiële gemeentelijke planning : de algemene en de bijzondere plannen van aanleg (A.P.A. en B.P.A.) (7), maar ook de zg. struktuurplannen, masterplannen, enz., die de facto als interne leidraad voor het gemeentelijk beleid fungeren kunnen niet terzijde gelaten worden. Hetzelfde geldt voor de plannen die nog in een ontwerpfaze verkeren of waarvoor een wijzigings-

(1) VAN RULLER, H., Agglomeratieproblematiek in Nederland, Alphen a.d. Rijn, 1972, p. 15 .

(2) M.M. VAN DER POEL, Wat is er sociologisch aan ruimtelijke ordening, Nijmegem, 1965, p. 22.

(3) Kenneth L. KRAEMER, New Comprehensiveness in city-planning. In : Public Administration Review, 1968, p. 382.

(4) Op. cit.

(5) Wet van 26 juli 197l, art. 4, par. 2.

(6) Het toewijzen van de R.0. aan de (samengevoegde) Zweedse gemeenten heeft deze lokale besturen dermate in reliëf gebracht, dat in tegenstelling tot de overige Europese landen geen gewestvorming overwogen wordt. Zie o.a. F. DELMARTINO, De herstructurering en herwaardering van de locale besturen in Zweden. In : De Gemeente, 1974/3, pp.156-163.

(7) Wet van 29 maart 1962, houdende organisatie van de ruimtelijke ordening en van de stedebouw, art. 14 en 15. 
procedure werd ingezet. Belangrijk is immers een zo volledig mogelijk zicht op het geheel van de planningsinitiatieven, omat zij bijzonder verhelderend zijn voor de genomen beleidsopties.

Steeds meer besturen beperken zich niet langer tot de planning en willen aktief optreden bij de verwerkelijking ervan. Meestal kreëren ze daartoe een grondregie, een soepel instrument dat de gemeente in staat stelt gronden te verwerven en weer te verkopen zonder komplexe adminiscratieve procedure. Het uiteindeijjk perspektief voor deze transakties kan een uitgesproken socialisering van het grondbezic zijn, doch meestal is de motivering veel pragmatischer van aard. Het bestuur wil een zekere reserve aanleggen van geschikte terreinen voor gemeenschapsdoeleinden of sociale woningbouw. Ook het tegengaan van ongezonde grondspekulatie, met name in de binnenstad, speelt hierbij een rol. Het spreekt vanzelf dat dit grondbeleid in een eigenlijke of oneigenlijke, inchoatieve zin, een bijzonder licht werpt op het overheidsinitiatief in deze beleidssfeer.

Belangrijk is echter niet enkel de instrumenten te bestuderen, maar ook de domeinen warin de overheid via haar ruimtelijk beleid intervenieert. Zowat in alle gemeenten treft men in dit verband volgende aandachtspunten aan :

- de woringbouw in het algemeen en de sociale woningbouw in het bijzonder. Niec alleen worden de woonzones in de plannen afgelijnd en heeft men oog voor de interne urbanistische vormgeving (het woonmilieu), maar cok het bouwvolume als geheel wil men beïnvloeden met daarbijeen bijzondere aandacht voor de differentiatie in het aanbod. In verschiliende mate spelen de matschappijen voor sociale woningbouw in op dit gemeentelijk beleid. In enkele gevallen treedt de gemeente ten andere zelf op als bouwheer, al dan niet in interkommunaal verband.

- de sanering of sloping van ongezonde en/of onbewoonbare woningen en buurten. De akuiteit van dit probleem stelt zich in verschillende mate, maar in vanouds verstedelijkte centra kan dit een prioritaire optie worden.

- de stadskemuemrienwing, die zich niet beperkt tot het saneren van woningen en het valoriseren van het historisch patrimonium in de bianenstad, naar de 'leefbaarheid' als dasdanig central stelt. Dit onvat 
een kritische benadering van de industriële inplantingen en van de ongeremde groei van de tertiaire diensten, en loopt meestal uit op een herwaardering van de woonfunktie en een heroriëntering van de verkeersstroom (o.a. verkeersvrije straten).

- de verantwoorde inplanting van de socio-kulturele infrastruktuur, inklusief de sportvoorzieningen en de rekreatiezones.

- de situering van de industriële en semi-industriële ondememingen, mede in funktie van de eventuele milieuhinder.

- de verkeersontsluiting en de verkeersinfrastruktuur in het algemeen. Geen van deze - en eventueel nog andere - uitzichten van het ruimtelijk beleid mag in een systematische benadering ontbreken, op gevaar af de onderlinge samenhang te doorbreken. Deze beleidssfeer is inderdaad slechts ten volle indikatief voor het geheel van het beleid, indien men niet éen of ander facet isoleert, maar vooral het samenspel van het beleidsinstrumentarium en de beleidsrealisaties in de verschillende domeinen in het licht stelt. Daartoe is de opbouw van een doeleindenstruktuur bijzonder geëigend, omdat opties, middelen en realisaties er in een spanningsveld gekonfronteerd worden met de doeleinden. Slechts bij een benadering van het ruimtelijk beleid als geheel, kunnen de accenten en prioriteiten naar hun juiste draagwijdte beoordeeld worden, en komen ook de domeinen in negatief reliëf die gekenmerkt worden door een beleidsvacuüm.

De ordenende taken komen met een 'comprehensive' beleidssfeer als ruimtelijke ordening (planning, grondbeleid, woonbeleid, infrastruktuurbeleid) in deze analyse flink aan bod. Vandaar dat een tweede luik betrekking zal hebben op de eerder verzorgende taken, mits de weerhouden taaksfeer ook voldoet aan de criteria van beleidsrelevantie en schaalgevoeligheid. De socio-kulturele beleidssfeer in de brede betekenis beantwoordt $o . i$. best aan deze verwachtingen. Sinds enkele jaren staat ze nl. niet enkel in het brandpunt van de matschappelijke belangste1ling, maar is vanuit haar tweederangspositie in de overheidstaakbehartiging naar het voorplan geschoven van de politieke decision-making. Het traditioneel subsidiëringsbeleid is verruimd tot een investeringsbeleid, en ondanks de criteria die de provinciale en nationale overheid hanteert bij het financieel ruggesteunen van de projekten, blijft deze 
materie heel wat 'vrijer' voor de lokale besturen dan de meeste andere verzorgende taken. Er blijft ruimte $n 1$, om al dan niet in te spelen op de specifieke noden van déze gemeente, van déze deelgemeente, van déze bevolkingskategorie. Vandaar dat deze beleidssfeer, samen met deze van de ruimtelijke ordening, een goede indikator is voor de kwaliteit en de innoveringskracht van het gevoerde beleid : de behoefte-gevoeligheid, de beleidsvoorbereiding in dialoog met de betrokken bevolking, de prioriteitsbepaling tussen de mogelijke projekten. Ook de beleidsmogelijkheden vinden hier een toets : wat kan deze gemeente aan op het vlak van de investeringen in de niet-traditionele sektor? Tenslotte is deze beleidssfeer ook schalgevoelig. Naast de infrastruktuur op gemeentelijk niveau, zijn er voorzieningen die duidelijk een agglomeratie-overleg en wellicht ook een agglomeratie-samenwerkingsverband vragen. Maar ook de eventuele voorzieningen op sub-gemeentelijk niveau, in de kerkdorpen en de wijken, horen grotendeels tot deze beleidssfeer. Hoe kadert de besluitvorming hieromtrent in het geheel van opties en doeleinden van de gemeente?

Ook deze beleidssfeer vertoont een antal uitzichten die we met het oog op het onderzoek moeten expliciteren :

- het kultureel beleid in de strikte zin. Hieronder ressorteren de kulturele infrastruktuur (schouwburg, museum, bibliotheek, diskotheek, kultureel centrum, enz.) en het stimuleren van de kulturele manifestaties in het algemeen. Het kunstonderwijs (conservatorium, muziekakademie, akademie voor plastische kunsten, enz.) komt hierbij ook onvermijdelijk ter sprake, evenals de restauratie en valorisering van het historisch patrimonium.

- het socio-kultureel beleid, dat eerder gericht is op het volksontwikkelingswerk in verenigingsverband (de socio-kulturele verenigingen), de amateuristische kunstbeoefening en de vrijetijdsbesteding in het algemeen.

- het sportbeleid, waarbij de infrastruktuurwerken (sportha11, zwembad, enz.) de grootste andacht krijgen, maar dat ook de popularisering van de aktieve sportbeofening nastreeft. 
- het jeugdbeleid. Deze beleidstaak wordt meestal nog traditioneel opgevat als een steun aan verenigingen, eventueel ook bij de uitbouw van hun vergaderlokalen. Ook de aanleg van speelpleinen zouden we echter onder deze hoofding ter sprake wilien brengen.

- de welzijnszorg in de mate dat deze door het gemeentebestuur (en niet door de C.O.O.) behartigd wordt. Meestal gaat het hierbij om een gemeentelijke suciale dienst, gemeentelijke diensten voor gezins- en bejaardenhulp, een gemeentelijk kinderdagverblijf of peutertuin, enz. Deze diensten behoren wel niet meer tot de socio-kulturele beleidssfeer zoals deze traditioneel omschreven wordt, maar kunnen hierbij zinvol betrokken worden omdat ze inspelen op een behoeftenformulering vanuit het verenigingsleven en de inspraakorganen (gezinsraad, bejaardenraad). In deze zin sluit de 'welzijnszorg' dus aan bij de funktie samenlevingsopbouw, die toch het bindteken is van de hele socio-kulturele beleidssfeer.

Een belangrijke en in dit verband erg relevante beleidstaak is hier nog onbesproken gebleven : het milieubeleid. Wellicht is deze lakune te wijten aan de ambivalente opstelling tussen de ordenende en de verzorgende taken. Als preventieve zorg voor de milieuhygiëne is deze beleidstaak inderdaad eerder ordenend, maar via een aantal aspekten hoort de milieuzorg ook thuis bij de verzorgende taken. En dit niet alleen omwille van de opvoeding tot milieuverantwoordelijkheid, warin het verenigingsleven naast het onderwijs een rol te spelen heeft. Heel wat infrastruktuurprojekten zijn thans polyvalent opgevat : een natuurgebied wordt gered, beschermd, gevaloriseerd, aangelegd, vaak onder de druk van aktiekomités of als gevolg van een groeiend besef van de waarde van groenzones voor het leefmilieu en het leefklimaat. In het kader van deze valorisering voor gemeenschapsgebruik, worden de mogelijkheden inzake passieve rekreatie soms uitgebreid tot voorzieningen voor aktieve rekreatie, sport, spel en socio-kulturele aktiviteiten in het algemeen. Vandaar dat het milieubeleid als een geschikte tussenschakel kan fungeren tussen ordenende en verzorgende taken.

Uit de aandachtspunten die bij de gesprekken met de gemeentebesturen centraal zullen staan, zou niet zozeer een kompleer, maar wel een koherent beeld van het gemeentebeleid naar voor moeten komen. De onderzochte 
beleidstaken, gegroepeerd in beleidssferen, slaan inderdaad niet noodzakelijk op de meest bezwarende uitgavenposten of de diensten met de zwaarste personeelslast, maar willen wel de 'pointe' van het beleid vatten, vooral dan in toekomstperspektief.

\subsection{OPBOUW VAN DE DOELEINDENSTRUKTUUR}

\subsubsection{De triads optie-middel-doel}

'Beleid' werd met Hoogerwerf in een dynamische zin benaderd ( 1 ), $\pi$. als een "streven bepaalde doeleinden met bepaalde middelen en in een bepaalde tijdsvolgorde te bereiken" (2). Deze doeleinden berusten echter oorspronkelijk op een 'besluit' persoonlijk of in groep genomen (3). Omdat de beleidsvorming - zeker op het lokale vlak - nu eenmal niet zuiver rationeel verloopt en m.b.t. de doeleinden niet steeds formele beslissingen op te sporen zijn, zouden we deze 'besluiten' liever 'taakstellingen' of 'opties' noemen. Opties kunnen immers ook berusten op informele afspraken binnen het kollege, de meerderheidspartij, de koalitie. In sommige gevallen worden ze zelfs helemal niet geëxpliciteerd. Toch is hun impakt er niet minder groot om.

In het spaningsveld tussen opties en doeleinden staan de middelen. Relevant voor ons onderzoek zijn vooral de mobilisatie en de allokatie van deze middelen. T.a.v. bepaalde niet-kwantificeerbare doeleinden komt het vaak voor dat ook de middelen niet kwantitatief uitgedrukt kunnen worden. Men kan uiteraard de allokatie van de financiële middelen nauwkeurig situeren en hieruit een aantal prioriteiten afleiden.

Maar ook de plannen van aanleg, de regieën, de interkommunale samenwerking, het beroep op provinciale of staatsinterventie, de privé-stichtingen enz. zouden wij in dit verband tot de - vaak effekrieve - middelen willen rekenen warover een lokaal bestuur in de Belgische irscitutionele kontekst beschikt.

(1) Cfr. supra, $\$ 1.1$.

(2) A. HOOGERWERF, De analyse van de beleidoinhoud, in: Beleid belicht I, p. 84 。

(3) Ibidem, p. 85. 
Kan men een vrij grote differentiatie vaststellen bij de beleidsmiddelen, dan is deze verscheidenheid al even groot bij de beleidsdoeleinden. Men zou ze kunnen onderscheiden naar de mate van hun explicitatie, specifikatie en kwantificering (1). Voor onze analyse is vooral het onderscheid belangrijk tussen einddoelen en tussendoelen. De middelen (ook wel 'input standard' genoemd) verwijzen inderdaad naar een uiteindelijke doelstelling (de 'output standard'), maar deze wordt meestal slechts verwezenlijkt via tussendoelen die op hun beurt weer middel zijn naar het 'hoger' doel. Eénzelfde objektief vastgesteld gegeven kan aldus nu eens geinterpreteerd worden als beleidsdoel, dan weer als beleidsmiddel of beleidseffekt. "Het onderscheid tussen doeleinden en middelen kan empirisch slechts vastgesteld worden binnen een bepaalde theoretische en empirische kontekst, d.w.z. binnen het kader van een bepaald beleid. Eerst nadat men binnen een bepaalde kontekst het doel heeft ontdekt, kan men de middelen voor dat doel empirisch vaststellen. Eerst nadat men heeft vastgesteld wat het einddoel is kan men de tussendoelen ontdekken" (2). Om juist dit 'einddoel' te vatten zal de analyse moeten slaan op het geheel van de al dan niet geëxpliciteerde opties, middelen en doelstellingen.

Ook de beleidsrealisaties zijn o.i. in deze doeleindenstruktuur op hun plaats. Het zijn niet zozeer kritisch getoetste beleidseffekten, maar eerder aanwijzingen over de faze van realisatie van de opties. In zekere zin kunnen ze door hun werkelijkheidswaarde het beleidsstreven relativeren of versterken.

Zelfs indien de onderzoeker de logische orde kon ontdekken in de beleidsopbouw en dus welke middelen op welke doeleinden zijn afgestemd, dan staat hij nog voor de synthesevraag. Doeleinden moeten onderling gekoördineerd worden en hetzelfde geldt voor de middelen : welke is de feitelijke rangorde van uiteindelijke doeleinden, hoofddoeleinden en nevendoeleinden? Deze synthese is bijzonder moeilijk te vatten door de empirische beleidsonderzoeker, ook al omdat de uiteindelijke doeleinden bijna nooit door de betrokken beleidsvoerders geëxpliciteerd wor-

(1) Zie bv. het onderscheid dat D. VAN HOUTEN maakt tussen richtdoelen en objektdoelen - Cfr. supra $\$ 1.2$.

(2) A. HOOGERWERF, op. cit., p. 90. 
den. Toch 1 ioge het ons belangriok een poging te ondernemen on te te

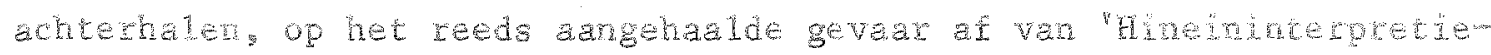
mug". In de witeindelijke coeleinden hopen we inmers indikaties te

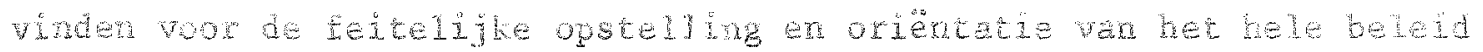
in de stadmomeland konkekst. Meer gespecifiect vermachen we ean orienterend antwoord op vager als: Woert deze randgeneente het veelzijdig bele van een autonome entiteit, of is hax beleid de tacto

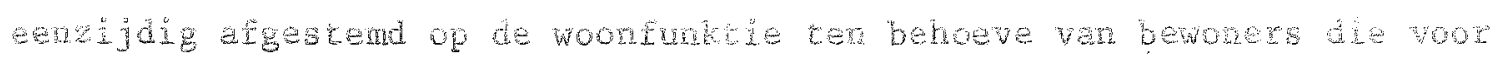

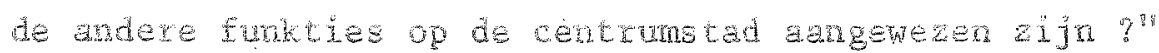

Eeder als hypothese geformleerd zouden we kunez stelhen dat de atar-

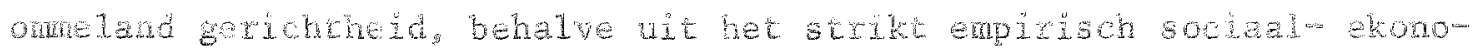

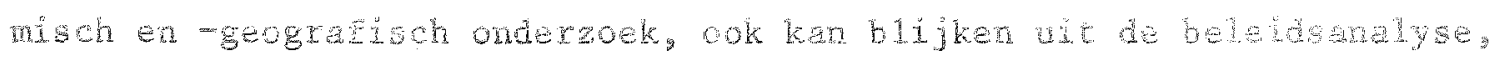

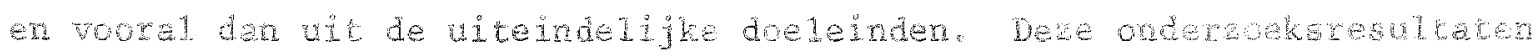

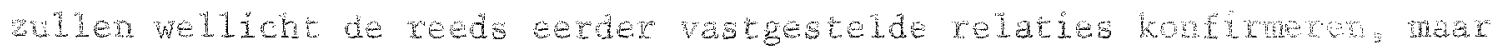
hebsen vamit hun binmbesturlijke opstelling het voonded det ae het dossier van de aggloneratievoming in belangrijke mate vemblren, zow dat een meer geruenceerde probleemoplosing nagestreetd kan worden.

De "logische orde" in de triade optie-midel-wol, dea "lijn" in de beleidspoming. zouden we ook letterlitk met een lijn willen dandulder in de schematische voorstelling. Uit al het poorgande blifkt we tet overw

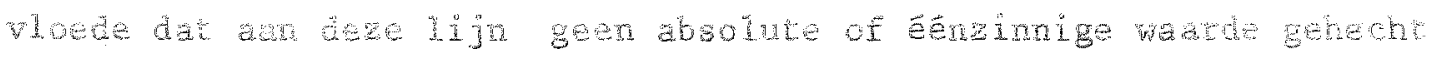

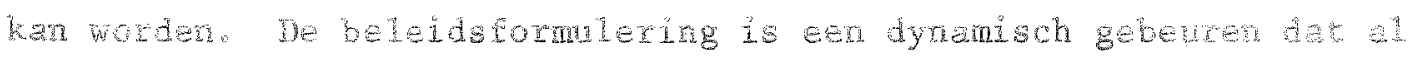

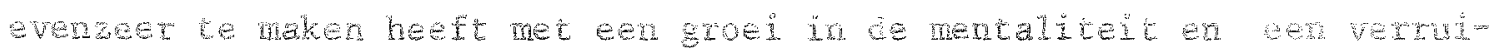

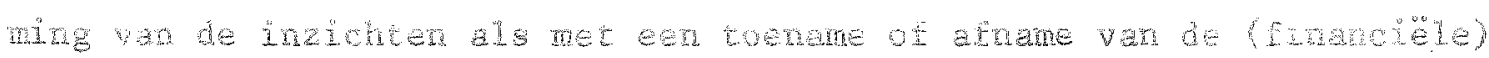
madelen. De opyatingen, begingelen, romen en gedragirgen die an

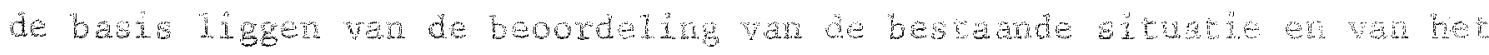

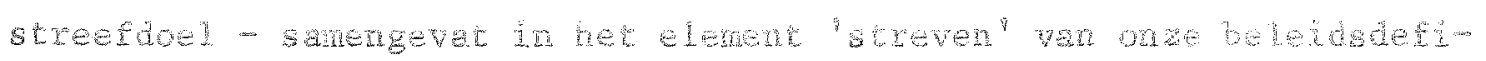

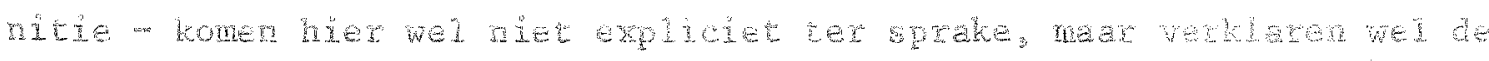

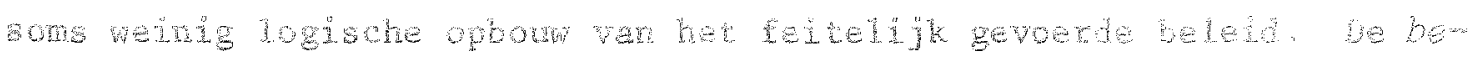

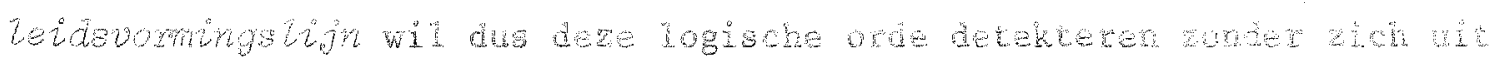

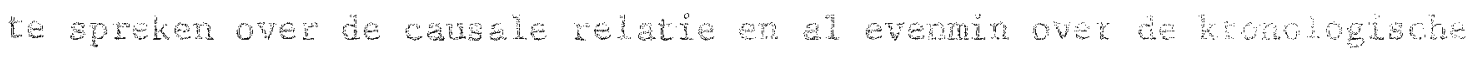
operavelgirig.

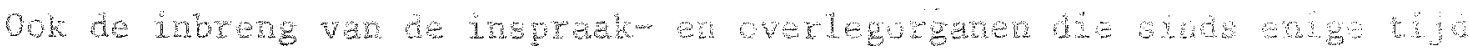

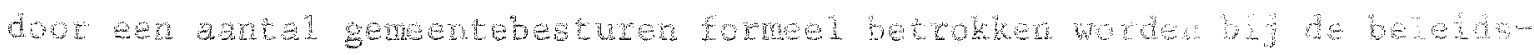

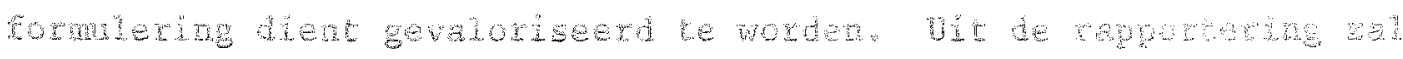

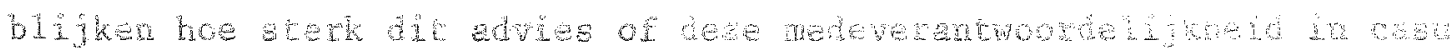


gerelativeerd moeten worden. Binnen eenzelfde gemeente, en dus in het kader van eeênzelfde doeleindenstruktuur, kan het ene overlegorgaan een zeer reële inbreng hebben, terwijl de invloed van het andere inspraakorgaan quasi fiktief blijft. Ondanks deze moeilijkheid bij de voorstelling worden de inspraak- en overlegorganen steeds opgesomd, en blijkt uit een aparte (stippe1)lijn t.a.v. welke opties, realisaties en doeleinden ze mede-formulerend optreden.

\subsubsection{Praktische uitwerking van de conalyse}

\subsubsection{De beleidssferen}

De criteria die gehanteerd werden bij de selektie van de overheidstaken die voor deze analyse in aanmerking komen, werden reeds toegelicht (1). Inspelend op het onderscheid tussen ordenende taken en verzorgende taken, werd uit elk van beide taaksferen éên brede beleidssfeer weerhouden die als bijzonder relevant en indikatief naar voor kwam, te weten : het sociaal-ruimtelijk beleid enerzijds, het socio-kultureel beleid anderzijds. ook het milieubeleid werd bij de analyse betrokken omwille van zijn brugfunktie.

Het samenbrengen van overheidstaken in beleidssferen lijkt ons een noodzakelijke voorwaarde om een zinvolle inhoudelijke beleidsanalyse door te kunnen voeren. In de bestuurspraktijk worden deze overheidstaken echter als autonoom gepercipieerd, of op basis van andere criteria ingedeeld. De beleidsvoerders zullen bv. de industriële inplanting of de verkeersontsluiting meestal als quasi-autonome problemen bespreken en ze niet spontaan koppelen aan het overig sociaal-ruimtelijk beleid. Idem voor wat de sport betreft in de socio-kulturele beleidssfeer. In de dialoog met de gemeentebesturen werden de verschillende uitzichten van deze ruime beleidssferen dan ook separaat onder de loep genomen en slechts bij de synthesevorming in een meer logische orde gegroepeerd. In het doeleindenschema vindt men deze opsplitsing terug. Onder de noemer 'grond- en woonbeleid' worden ook planning, sanering en stadskernhernieuwing besproken. De ordenende taken die daarentegen betrekking hebben op de industriële vestiging en de verkeersinfrastruktuur krijgen

(1) Cfr. supra, $\S 2-3$. 
een aparte behandeling. Milieubeleid en socio-kultureel beleid situeren zich bij de schematische voorstelling en de detailbespreking tussen beide aspekten van de sociaal-ruimtelijke beleidssfeer in. Deze meer gespreide opstelling van de beleidssferen sluit niet enkel beter aan bij de feitelijke opeenvolging van de aandachtspunten in het gespreksschema, maar makt ook de bespreking overzichtelijker. Een benadering van de beleidstaken zoals ze worden gepercipieerd door de beleidsvoerders lijkt ons inderdaad in een eerste faze van de rapportering het meest werkelijkheidsgetrouw. In een tweede faze kan de onderzoeker dan zinvolle verbanden opsporen en de koherentie van het gehele beleid toetsen.

\subsubsection{De beleidsopties}

Een dubbele precisering dringt zich hier op : aan welke criteria moeten de opties voldoen om weerhouden te worden en welke beperking in de tijd hanteren we als leidraad hierbij ? Willen de verschillende doeleindenstrukturen immers vergelijkbare gegevens opleveren, dan mosten ook vergelijkbare criteria angelegd zijn bij de selektie van de basiselementen van deze struktuur : de beleidsopties.

Deze opties zijn inderdaad niet zonder meer te registreren, allereerst omdat ze verschillend van aard zijn, en secundo omdat ze - evenals de doeleinden - vaak weinig geëxpliciteerd zijn. De optie alle krotwoningen in een bepalde buurt op te ruimen of de gemeente vit te rusten met een polyvalente ruimte voor indoor-sport is gemakkelijker te detekteren en te toetsen dan een al even belangrijke optie als het systematisch afremmen van de eenzijdige expansie van de tertiaire funkties in de binnenstad. Voor beide kategorieën van opties zal de evaluatie van de feitelijke realisaties en ontwikkeling de beste toetssteen vormen. In het ene geval kan het werkelijkheidsgehalte van de optie met vrij grote zekerheid getoetst worden, in het andere geval echter gaat het om een optie die moeilijk geísoleerd kan worden uit een bredere kontekst van standpunten, matregelen en doeleinden en die hoe dan ook slechts op termijn te evalueren is. Niet an elke optie beantwoordt dus in onze struktuur een onmiddellijk aan te wijzen realisetie. Toetssteen voor het werkelijkheidsgehalte van de verklaringen van de beleidsvoerders is veeleer het formele karakter van de beslissing en/of de matregel die ter realisatie van de optie genomen zijn. De principiella beslissing in de gemeenterad, het inzetten van de administratieve prucedure, 
het uitvaardigen van een reglement, het opmaken van een plan, enz. zijn evenzoveel indikaties voor de onderzoeker dat de aangehaalde opties uitstijgen boven de 'wishful thinking'-toekomstplannen. Deze toets is beslistniet absoluut veilig. Principiële beslissingen leiden niet trefzeker naar een realisatie op korte termijn, reglementen kunnen dode letter blijven, op te nemen leningen kunnen achteraf weer geschrapt worden, enz. Desondanks kan men zich bij een beleidsanalyse als deze niet beperken tot de afgewerkte realisaties, of - in financiële termen gesteld tot de goedgekeurde rekeningen. Een doeleindenstruktuur is veeleer een momentopname, opgebouwd met opties van verschiliende aard : 'tastbare' besluiten en intentieverklaringen. Elk van deze elementen moet getoetst worden op zijn werkelijkheidswaarde maar kan niet aan dezelfde normen onderworpen worden.

Dit is des te meer het geval omdat de opties in een verschillend stadium van realisatie verkeren. De ene optie heeft reeds aanleiding gegeven tot een anwijsbare realisatie, de andere doorloopt de voorbereidende fazen, een derde bestaat nog maar in projektvorm. Wil men elk van deze elementen in een synthese betrekken - zoals de doeleindenstruktuur beoogt te zijn - dan moet men niet te ver in het verleden delven en zich veeleer toekomstgericht opstellen. In principe weerhouden we dan ook slechts de opties en de realisaties van de laatste vijf jaar, hetgeen ongeveer overeenkomt met het mandaat van de huidige gemeenteraden en schepenkolleges. Deze zijn in funktie getreden op 1 januari 1971 maar hebben vanaf 1969-70 hun beleidsplannen ontvouwd in de verkiezingspropaganda. Samen met de realisaties van de aftredende meerderheid, vormen deze beleidsintenties een relevant aanknopingspunt om met de beleidsanalyse van start te gaan. Het empirisch onderzoek werd anderzijds afgesloten medio 1974.

Het spreekt vanzelf dat de huidige situatie niet te begrijpen is zonder een elementaire verkenning in de ruimte en de tijd. Vandaar dat naast een inleidende ruimtelijke survey ook enkele gegevens verstrekt worden over de historische achtergrond van de gemeente. Belangrijker dan het verre verleden zijn in dit verband echter de grote opties die het huidige beleid nog beinvloeden of bepalen. In de bespreking wordt hierop ingegaan, terwij 1 ook de meest markante investeringen uit de twee voorgaande mandaten (1959-1964, 1965-1970) aangehaald worden. Deze achtergrond 
wil nochtans op geen enkele wijze het verleden rekonstitueren, doch enkel het huidige beleid situeren in het spanningsveld tussen traditionele taken en toekomstige opdrachten.

\subsubsection{Schematische voorstelling en ondersteunende bespreking}

Een analyse van de doeleindenstruktuur mondt uit in een drietal elementen. Centraal staat de schematische voorstelling van het geheel van opties, middelen, realisaties en doeleinden, een synthese dus van zinvolie verbanden die kulmineert in de uiteindelijke doelstellingen. Het achterhalen van deze samenhang, deze 'logische orde' vormt zoals gezegd het kernmoment van de analyse (1). Toch kan het schema niet los gezien worden van een ondersteunende en interpreterencie bespreking Geissoleerde woorden dekken vaak een verschillende lading, de absolute waarde en relatieve betekenis van bepaalde opties en reailsaties moet gepreciseerd worden, kontekst en samenhang dienen verduidelijkt. Anderzijds wil de onderzoeker tot op zekere hoogte het meest relevante feitenmaterial ter ondersteuning aanbieden van zijn interpretaties en konklusies. Het is echter niet a priori duidelijk welke verfijning bij de gegevensverzameling nagestreefd moet worden om de validiteit van het centrale schema veilig te stellen.

2.4.2.3.1. Gradaties in de ondersteunende bespreking

zoals gezegd vond de eerste analyse plaats in het kader van een multidisciplinair onderzoeksprojekt dat de eventuele herstrukturering van acht gemeenten ten Westen van Kortrijk op het oog had (2). De doe1eindenstruktuur kon in dit geval verder bouwen op de gegevens die uit de andere deeìstudies naar voor kwamen (3).

In een tweede faze daarentegen ontbrak deze data-ruggesteun en moest de relevante informatie zelf ingewornen en verwerkt worden. Voor de drie testgemeenten in de Leuvense agglomeratie gebeurde dit op indringende wijze, zodat de bespreking kan steunen op een nauwkeurige kenis vaxi de beleidsopties en hun financiële reperkussies.

(1) Cer. supra, $\$ 2-4.1$.

(2) Cfr. supra, $\$ 2-2.4$.

(3) De gemeentelijke herstrukturering ten Westen van Kortrijk - 2 delen $V . B . S . G_{0}, 1972$. 
Wat de stad Kortrijk aangaat werd een tussenformule gekozen. Een verfijnde bespreking van het uitgavenpatroon i.v.m. elk van de beleidstaken leek ons hier minder aangewezen, omdat het samenspel met de acht gemeenten uit het stadsgewest zich vanwege het formatverschil moeilijk leent tot dit soort van vergelijkend onderzoek.

Het kan verwondering wekken dat niet éénzelfde norm werd aangehouden inzake de diepgang en de verfijning van de ondersteunende bespreking in elk der test-cases. De verklaring en verantwoording is dubbel. Ener$z i j d s$ was er het groeiend inzicht dat een doeleindenstruktuur moet kunnen steunen op expliciterend en toetsend feitenmateriaal. De eerste analyse overdoen was echter uitgesloten, gezien het éénmalig karakter ervan (1). Anderzijds kan men zich afvragen of de kleinere gemeenten wel zinvol benaderd kunnen worden met een éénvormig onderzoeksmodel dat noodzakelijkerwijze afgestemd is op de takendifferentiatie van de centrumstad. In de meer overzichtelijke situatie van de kleinere gemeenten kan wellicht aan de hand van een minder komplexe verkenning een even duidelijk inzicht verkregen worden in de krachtlijnen van het beleid.

\subsection{Kwalifikaties van de bespreking}

We makten reeds het onderscheid tussen de ondersteunende en de interpreterende bespreking. Ofschoon beide benaderingen in e1kaar verweven liggen en voortdurend naar elkaar verwijzen is het belangrijk het onderscheid duidelijk te stellen.

De ondersteunende bespreking beschrijft de beleidsopties, - middelen en -realisaties ter explicitatie van de doeleindenstruktuur zoals deze op schematische wijze is weergegeven. Dit beschrijven houdt echter ook een element van verklaring en evaluatie in : in welke ruimtelijke, sociale, politieke kontekst is deze optie te situeren ?, in welke faze van realisatie verkeert dit projekt ?

(1) Cfr. supra, $\S 2.1$ en 2.4 . 
De interpreterende bespreking bouwt verder op de ondersteunende bespreking en is er eerder op gericht verbanden te leggen, de samenhang te ontdekken binnen de doeleindenstruktuur van een gemeente, maar ook het samenspel in agglomeratieverband aan te tonen. Het spreekt vanzelf dat dit verwijzingen zal inhouden naar mogelijke alternatieven voor een optimale bestuursgeleding.

\subsection{De bespreking van het uitgavenpatroun (1)}

Eén van de meest relevante elementen uit de ondersteunende bespreking is uiteraard de analyse van de begrotingsramingen en de effektieve uitgaven. Ofschoon dit proefschrift in het teken stat van een kwalitatief-evaluatieve beleidsbenadering en zich niet wil wagen aan een financiële analyse, kan men de ondersteuning van de financiële gegevens niet missen, zowel als indikatie voor de beleidsopties als ter toetsing van hun absolute en relatieve waarde. Het weze dus duidelijk gesteld dat deze financiële ondersteuning zich ook tot deze rol wil beperken en de globale financiële problematiek van de lokale besturen hier niet ter sprake komt.

Om de evolutie in de uitgaven en de spreiding over de verschillende posten zodanig in reliëf te brengen dat ze indikaties opleveren voor een eventuele verschuiving in de opties, werden de financiële gegevens zoveel mogelijk omgerekend naar de besteding per inwoner en het peresit in het geheel van de iitgaven. Deze weergave vergemakkelijkt bovendien een vergelijking in de besteding per post tussen de verschillende gemeenten. Zulke vergelijkingen dient men natuurlijk met de nodige omzichtigheid te hanteren. De uitgaven mogen immers niet losgekoppeld worden van de taakbehartiging waar ze op slaan : de service-funktie van een centrum-stad ligt nu eenmal anders dan deze van een randgemeente. Toch kan de vergelijkende studie de accenten in het licht stellen die vergelijkbare gemeenten in hun dceleindenstriktur aangebracht hebben.

De uitgaven in de gewone dienst hebben betrakking op de periode 1971-74. Ze zijn ontleend an de rekenirigen over 1971 en 72 en de begrotingen voor 1973 en 74. Tussen de werkel ijk-vastgestelde uitgaven $(1971-72)$ en de begrotingsuitgaven (1973-74) ligi uiteraard én cesur. De besteding

(1) Om de 'leesbarirheid" van de ondersteunende en interprererende bespreking te bevorderen, werden in principe alle financiële tabellen naar bijlage 3 verwezen. 
in \% van het totaal kan hier voor overijlde konklusies behoeden. Ook met een absolute toename van de uitgaven ten gevolge van de inflatie moet rekening gehouden worden. De meest signifikante gegevens voor onze beleidsanalyse zullen dan ook gezocht moeten worden in de evolutie inzake relatieve besteding en dit in een vergelijkend perspektief.

Sommige uîtgaven worden geheel of ten dele gekompenseerd door specifieke inkomsten. De weddelast van het gemeentelijk onderwijzend personeel bv. wordt gekompenseerd door de weddetoelagen vanwege het Rijk. Soms overstijgen de inkomsten in het kader van een funktie zelfs de uitgaven. Frekwent komt dit bv. voor bij de funktie 'Handel-Nijverheid'. Het ware onverantwoord bij een bespreking van de beleidsopties niet het onderscheid te maken tussen de effektieve uitgavenposten ten laste van de gemeente en deze posten die gekompenseerd worden. Vandaar steeds dubbele tabellen : naast de klassieke voorstelling van de 'bruto'-uicgaven ook een overzicht van de angezuiverde of 'netto'-uitgaven.

Eenmaal het bedrag gepreciseerd is dat de gemeente voor dit bepaald dienstjaar per inwoner en in \% van het totaal van de gewone uitgaven wil besteden aan déze funktie, is het beleidsrelevant na te gaan in welke verhouding deze som opgesplitst zal worden tussen personeelsuitgaven, werkingskosten, overdrachten en schuld. Hieruit kan dan blijken of deze of gene beleidssektor al dan niet personeelsintensief is, of het de werkingskosten zijn die doorwegen of eerder de toelagen aan derden. Sterk indikatief is ook het aandeel van de schuld in het geheel van de uitgaven, als toets voor het investeringsbeleid in verleden en heden. In bepaalde steden, zo o.m. te Leuven, treft men tenslotte nog een vijfde kategorie aan : de interne verrichtingen. Deze binnen-bestuurlijke financieel-technische operaties worden hier enkel weerhouden om de vier andere kategorieën zo precies mogelijk te kunnen omschrijven.

Naast de uitsplitsing per funktie, en dit voor de begrotingsjaren 1973 en 74, werden er ook twee totalen berekend. Binnen elk der kategorieën werd het relatieve gewicht bepaald van elk der funkties, terwijl ook het procentueel aandeel van elk der kategorieën in het geheel der uitgaven werd nagegaan. Vooral in vergelijkend perspektief kunnen deze gegevens tot interessante konklusies leiden, wits ze voorzichtig geinterpreteerd worden. 
Het lag voor de hand bij de globale overzichtstabellen de indeling in funkties aan te houden zoals deze in de begrotingen en rekeningen gehanteerd wordt. Deze uniforme indeling makt het mogelijk de uitgaven in het kader van een bepaalde funktie in verschillende gemeenten te bestuderen zonder het gevaar te lopen dat achter éénzelfde nomenklatuur verschillende werkelijkheden schuilgaan. Bovendien laat een overzicht van de uitgaven dat verder reikt dan de hier bestudeerde beleidssferen toe, deze laatste juist berer te situeren en tevens een licht te werpen op belangrijke niet-onderzochte domeinen als het onderwijs en de gezondheidszorg.

Anderzijds is deze uniforme indeling weinig geschikt om op verfijnde wijze de beleidssferen te benaderen die we voor onze analyse weerhouden hebben. Deze bestaan $n 1$. hoofdzakelijk uit beleidstaken die nog maar sinds enige tijd tot de gemeentelijke taaksfeer behoren (bv. grondbeleid, stadskernvernieuwing), of althans pas in de jongste jaren tot volle ontplooiing kwamen (bv, aanleg van groenzones, sportinfrastruktuur). In de indeling per funktie situeren deze taken zich vooralsnog onder een veel te brede noemer of worden zelfs opgesplitst over verschillende funkties. Zo moet men de aanleg van groenzones onder Volksontwikkeling en Kunst zoeken, de stadskernvernieuwing ligt daarentegen gespreid over Verkeer-Wegen-Waterlopen (reorganisatie van het stratennet en de verkeersstroom), Huisvesting en Stedebouw (sanering, sloping, nieuwbouw) en Volksontwikkeling en Kunst (restauratie historisch patrimonium). In afwachting dat de officiële indeling angepast wordt aan de evolutie in de gemeencelijke opdrachten, zagen we ons verplicht het uitgavenpatroon van de geselekteerde beleidssferen volgens eigen indelingscriteria te benaderen.

Ten aanzien van de ordenende taken (grond- en woonbeleid, sociaal-ekonomisch en infrastruktuurbeleid) moeten als relevante financiële gegevens allereerst de investeringen aangehaald worden. Deels in de bespreking en waar zinvol ook in aparte tabellen worden de investeringen opgesomd die gedaan werden door de twee vorige bestuurskolleges (1959-1964 en 1965-1970) en door het huidig bestuur (1971-1973). Voor 1974 wordt een overzicht gegeven van de investeringsuitgaven die in de begroting opgenomen zijn. Uit deze tabellen bijjkt de absolute inspanning van de gemeente sinds het begin van de zestiger jaren, maar ook bet relatie- 
ve gewicht van de investeringen in deze sektor t.a.v. het geheel van de investeringen.

Het is echter vooral in de socio-kuiturele beleidssfeer dat een verfijnde financiële ruggesteun van de algemene bespreking ten volle tot haar recht komt. Alle beschikbare gegevens uit de rekeningen over 1971 en 72 en de begrotingen voor 1973 en 74 werden er samengebracht rond de vier uitzichten die ook in de bespreking onderscheiden worden : milieubeleid, sportbeleid, kultuurbeleid en jeugdbeleid. Voor elk van deze deelsferen worden de uitgaven in absolute cijfers uitgesplitst volgens de kategorieën personeelskosten, werkingskosten, overdrachten en schuld, maar ook relatief gesitueerd : de besteding per inwoner en in \% van de totale uitgaven. Aan deze analyse van de uitgaven in de gewone dienst beantwoordt een tweede luik, nl. dit van de investeringsuitgaven. Volgens het stramien dat hierboven beschreven werd m.b.t. de ordenende taken, reikt dit overzicht echter heel wat verder in het verleden en worden alle investeringen sinds 1959 exhaustief opgesomd.

De financiële ruggesteun voor de bespreking van de socio-kulturele beleidssfeer gaat wel heel wat verder dan dit noodzakelijk was ter eenvoudige toetsing van het werkelijkheidsgehalte van de aangehaalde opties. op dit beperkte terrein van ons onderzoek verwijzen beide panelen van het tweeluik 'gewone dienst - investeringen' voortdurend naar elkaar, en vullen elkaar zelfs aan. Het leek ons voor de verdere ontwikkeling van de methodiek van de beleidsanalyse bijzonder boeiend na te gaan of - en zo $j a$, in welke mate - de descriptieve methode waarvoor we in dit proefschrift opteerden kan en/of moet samengaan met een financiële analyse, en omgekeerd. M.a.w., zijn doeleindenstruktuur en financiële analyse autonome beleidsbenaderingen of komponenten van een volwaardige beleidsanalyse? 


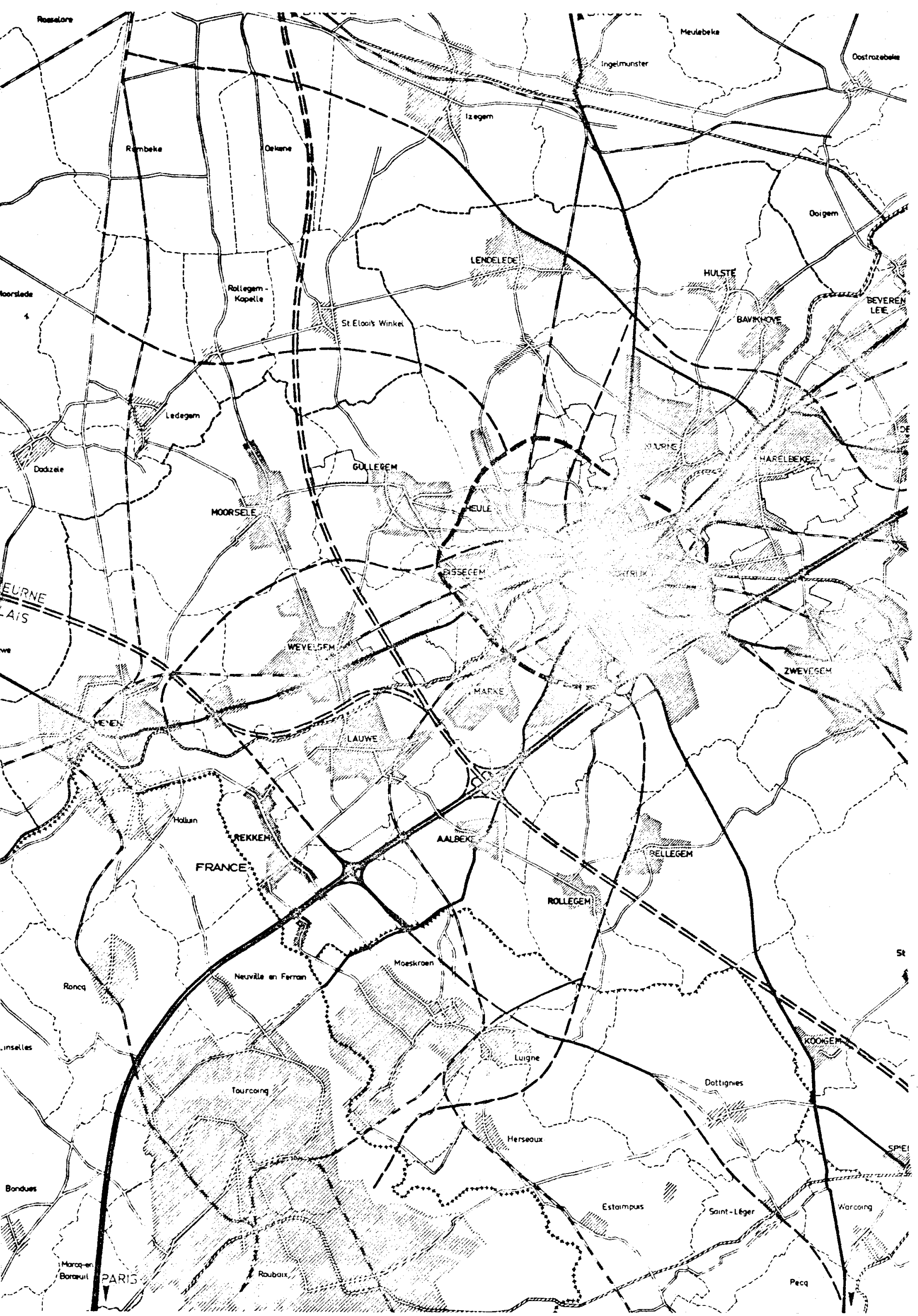




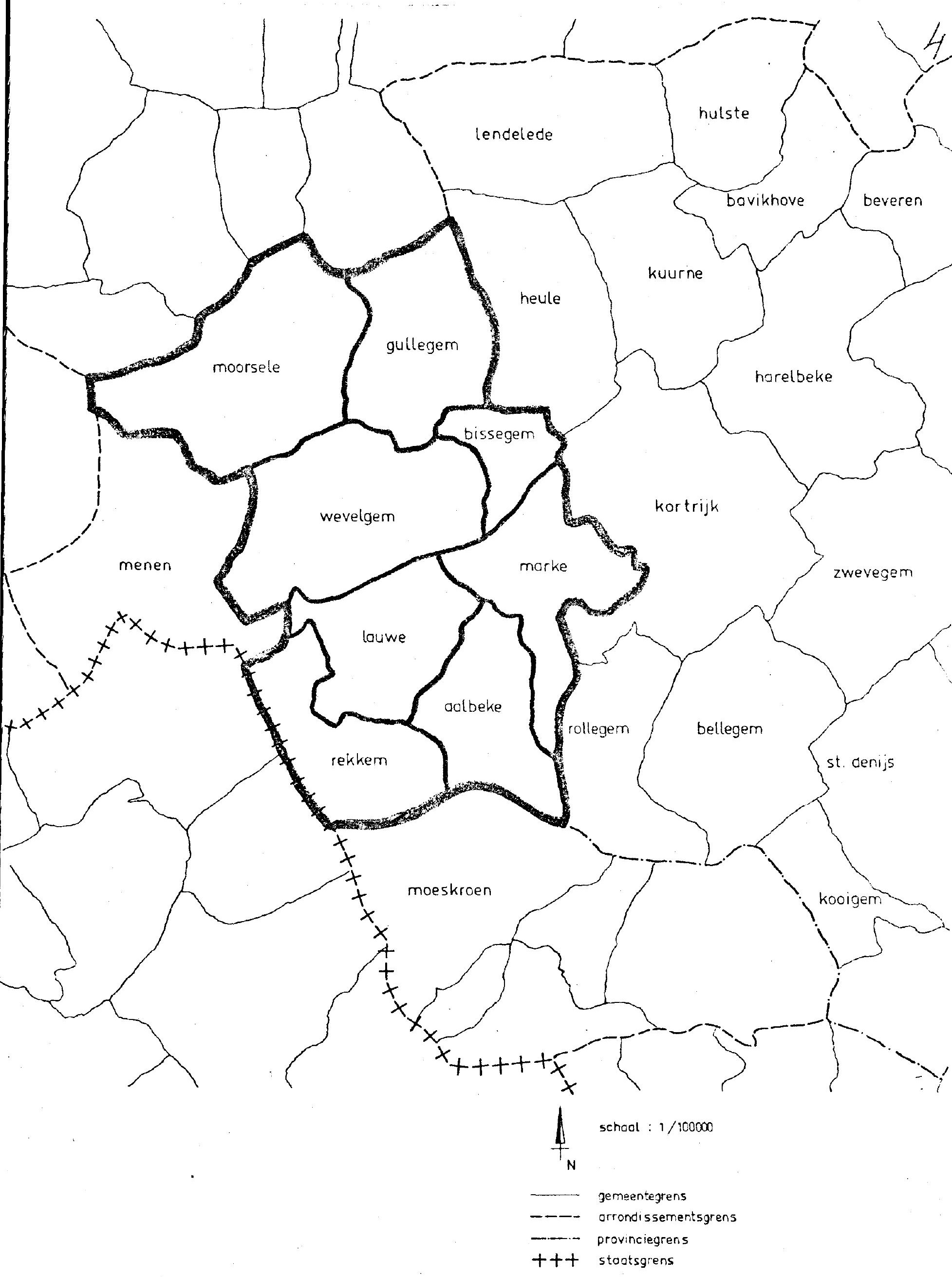




\section{$\S 3$. Doeleindenonderzoek van de kortrijkse agglomeratie}

Medio 1972 formuleerden acht gemeenten ten Westen van Kortrijk gelegen (1) de wens hun onderling relatiepatroon en hun betrokkenheid bij de Kortrijkse agglomeratie verhelderd te zien met het oog op een positiebepaling t.a.v. de zich aandienende bestuurlijke herstrukturering (2). Het onderzoek, dat toevertrouwd werd aan de Vereniging van Belgische Steden en Gemeenten (3), omvatte naast de kiassieke komponenten (overzicht van de funktionele uitrusting, sociaal-geografische verkenning, financiële analyse) voor het eerst ook een doeleindenonderzoek. Met de acht betrokken bestuurskolleges werd in novenber 1973 inderdaad getracht de krachtlijnen van het gevoerde beleid en de verdere ontwikkelingsperspektieven in een koherente doeleindenstruktuur uit te drukken.

De ontbrekende schakel in het agglomeratie-onderzoek was de cencrum-stad Kortrijk zelf. De doorlichting vond hier medio 1973 plaats, ondersteund door een voorafgaande beleidsverkenning. De essentiële gegevens hieruit worden in deze studie opgenomen, terwijl dit niet het geval kan zijn voor het verkennend onderzoek in de acht randgemeenten dat door de V.B.S.G. werd uitgevoerd. Opdat deze lakune de leesbaarheid van het geheel niet in het gedrang zou brengen, worden een paar essentialia over de Kortrijkse agglomeratie in de introduktie tot de doeleindenstruktuur van de centrum-stad verwerkt.

De doeleindenstruktuur van stad en rand ( 8 schema's en een synthesepoging) zal tenslotte in een afsluitende bespreking onderling getoetst worden, om van hieruit een visie op de agglomeratieproblematiek te ontwikkelen.

(1) Het betreft Aalbeke, Bissegen, Gullegem, Lauwe, Marke, Morsele, Rekkem en Wevelgem.

(2) Cfr. supra $\S 2.2 .2$. : Selektie van de agglomeraties.

(3) De gemeentelijke herstrukturering ten Westen van Kortrijk - 1973, 2 delen, $189 \mathrm{p}+35 \mathrm{p}$ bijlagen. Analyse van de doeleindenstruktur : pp. $133-149+9$ schema's. 


\subsection{DOELEINDENSTRUKTUUR KORTRIJK}

\section{SITUERING}

De stad Kortrijk, die rond zich een aantal dichtbevolkte randgemeenten heeft (1), vormt hiermee een agglomeratie van nagenoeg 117.000 inwoners. Samen met Brugge heeft de Kortrijkse agglomeratie aldus de grootste kern-bevolking van alle regionale steden. In het éénduidig hinterland wonen zowat een kwart miljoen mensen (241.313), terwij1 de totale invloedssfeer het half miljoen overschrijdt (515.827) (2).

\begin{tabular}{|c|c|c|c|c|}
\hline Agglomeratie KORTRIJK & $\begin{array}{l}\text { Bevolking } \\
31.12 .1961\end{array}$ & $\begin{array}{l}\text { Bevolking } \\
31.12 .1970\end{array}$ & $\begin{array}{l}\text { Oppervlakte } \\
\text { in ha. }\end{array}$ & $\begin{array}{l}\text { Bevolkings- } \\
\text { dichtheid } \\
\text { in } \mathrm{km}^{2}\end{array}$ \\
\hline Kern-gemeente Kortrijk & 43.606 & 44.961 & 2.115 & 2.125 \\
\hline $\begin{array}{l}\text { Randgeme enten (3) } \\
\text { Heule } \\
\text { Kuurne } \\
\text { Harelbeke } \\
\text { Zwevegem } \\
\text { Marke* } \\
\text { Bis segem* } \\
\text { Gullegem* }\end{array}$ & $\begin{array}{r}9.057 \\
11.173 \\
16.779 \\
10.654 \\
4.559 \\
4.855 \\
7.009\end{array}$ & $\begin{array}{r}9.605 \\
13.022 \\
18.498 \\
11.904 \\
5.803 \\
5.534 \\
7.638\end{array}$ & $\begin{array}{r}1.171 \\
1.090 \\
1.488 \\
1.559 \\
821 \\
341 \\
960\end{array}$ & $\begin{array}{r}820 \\
1.194 \\
1.242 \\
763 \\
706 \\
1.621 \\
795\end{array}$ \\
\hline Totaal agglomeratie & 107.692 & 116.965 & 9.545 & 1.225 \\
\hline $\begin{array}{l}\text { Groep van } 8 \\
(+3 \text { gemeenten met } *) \\
\text { Aalbeke } \\
\text { Lauwe } \\
\text { Moorsele } \\
\text { Rekkem } \\
\text { Wevelgem }\end{array}$ & $\begin{array}{r}2.614 \\
7.659 \\
4.780 \\
4.807 \\
12.805\end{array}$ & $\begin{array}{r}2.809 \\
7.748 \\
5.211 \\
4.648 \\
13.913\end{array}$ & $\begin{array}{r}713 \\
879 \\
1.498 \\
789 \\
1.398\end{array}$ & $\begin{array}{l}394 \\
881 \\
348 \\
588 \\
995\end{array}$ \\
\hline $\begin{array}{l}\text { Totaal arrondissement } \\
\text { ( } 41 \text { gemeenten) }\end{array}$ & 246.965 & 263.838 & 40.315 & 654 \\
\hline
\end{tabular}

(1) De Atlas van België (kaarten 28 A-B-C) weerhoudt als zodanig Heule, Kuurne, Harelbeke, Zwevegem, Marke, Bissegem en Gullegem.

(2) Kommentaar op de Atlaskaarten 28 A-B-C.

(3) In de omschrijving van de Atlas van België, kaarten 28 A-B-C. 
In bijgaande tabel zijn de bevolkingscijfers gespecifieerd per gemeente. De 7 randgemeenten die met Kortrijk de agglomeratie vormen volgens de omschrijving van de Atlas van België, worden onderscheiden van de 8 gemeenten ten Westen van de stad die ons onderzoeksgebied uitmaken. Drie randgemeenten (Marke, Bissegem en Gullegem) vallen onder beide kategorieën. De bevolkingscijfers geven vooral een beeld van de demografische groei die het stadsgewest als geheel kenmerkt. De expansie van de randgemeenten springt hierbij in het oog, maar moet $0_{0} \mathrm{~m}$. in verband gebracht worden met een stagnerende tot licht dalende bevolkingskurve in de centrum-stad, vooral sinds 1970. In 1972 bv. kende Kortrijk een terugloop van 454 inwoners, hetgeen als een typisch agglomeratieverschijnsel te omschrijven is. De 5 niet-randgemeenten uit het overzicht blijven daarentegen veel bescheidener in hun groei. Rekkem noteerde zelfs een lichte bevolkingsdaling. Het betreft hier gemeenten uit een 'tweede gordel' rond de stad, die niet zo onmiddellijk bij de expansie van de agglomeratie betrokken zijn. Wevelgem neemt hierbij wel een aparte positie in vanwege zijn format en gunstige ligging op de as Kortrijk-Menen. Inzake tewerkstelling is het aanbod in de Kortrijkse agglomeratie groter dan in de provinciehoofdstad Brugge, n1. resp. 45.099 en 40.716 arbeidsplaatsen. De centrum-stad zelf heeft een aktieve bevolking van 16.325, waarvan er 3.518 buiten de gemeenten werken. De arbeidstoevoer naar de agglomeratie Kortrijk is echter veel groter (35\%) dan de uitgaande pendel (1). In vergelijking met andere regionale steden is de industriële werkgelegenheid in de agglomeratie Kortrijk sterk vertegenwoordigd. (2). De tertiaire tewerkstelling bedraagt daarentegen slechts $33,7 \%$. Het sociaal-geografisch onderzoek van de regionale steden in België rangschikt Kortrijk dan ook bij de industriële steden (3).

Qua niveau van uitrusting staan de medische- en onderwijsvoorzieningen in Kortrijk op een hoog peil, maar bereiken de overheidsinstellingen niet het niveau van Brugge (4). Inzake socio-kulturele infrastruktuur zou

(1) Stad Kortrijk : Aanvraag tot indeling van de stad in een hogere klasse, dd. 12 november 1971 .

(2) Bijlage bij de kommentaar op de atlaskaarten $28 \mathrm{~A}-\mathrm{B}-\mathrm{C}$ van de Atlas van België.

(3) De regionale steden van België - Sociaal-geografische studie Brussel, 1972 .

(4) Ibidem, deelstudie Kortrijk. 
de evaluatie hernieuwd moeten worden vanwege de oprichting van een polyvalent kultureel centrum.

De Kortrijkse agglomeratie verschijnt dan ook als de uitgesproken groeipool in Zuid-West-Vlaanderen. De randgemeenten zijn onmiddellijk betrokken bij deze expansie, maar de attraktie van de regionale stad reikt verder en beslaat nagenoeg het hele arrondissement. De westelijke flank van dit stadsgewest $z a l$ samen met de centrum-stad zelf het onderzoeksterrein vormen van onze beleidsanalyse.

\section{Grond- en woonbeleid}

\subsection{GRONDBELEID EN PLANNEN VAN AANLEG}

De oprichting van een gemeentelijk grondbedrijf (1 januari 1969) mag niet als het beginpunt van de overheidsbemoeiing in deze beleidssektor beschouwd worden. Reds in 1966 werd $n 1$. een struktuurplan ontworpen voor de hele Zuid-Oost-hoek van de stad. Dit agrarisch gebied van 223 ha. kwam toendertijd onder sterke spekulatieve druk te staan, en het was dan ook essentieel de bestemming ervan nauwkeurig vast te leggen om de veelzijdige ontwikkelingskansen van de stad te vrijwaren. Twee opties zaten hierbij voor : de uitbouw van een universitaire (K.U.L.A.K.) en een N.U.H.O.-campus (CATHO) enerzijds, een gedifferentieerd aanbod inzake huisvesting anderzijds. Aan de onderwijsfunktie werd 60 ha. effektief toegewezen, terwijl er nog 25 ha. in reserve gehouden worden. De woningbouwprojekten bespreken we zo dadelijk. Het grondbedrijf fungeert bij deze uitbouw als een soepel instrument ten behoeve van een aktiefinterveniërend stadsbestuur. In 1972 werden aldus 92 ha. in de $\mathrm{Z} .0$. -hoek verworven met het oog op diverse projekten, of gewoon als reserve. Hiermee was een bedrag van 200 miljoen F. gemoeid. Maar ook in de binnenstad treedt deze 'grondregie' bemiddelend op, vooral dan in het kader van de stadskernvernieuwing ( 1 ).

(1) Cfr. infra, sub. 1.4 . 
Sinds 1968 werden er anderzijds $11 \mathrm{BPA}^{\prime}$ s goedgekeurd of herzien, terwij1 er 3 in ontwerp zijn en nog 7 andere gepland worden. Alleen reeds deze vaststelling wijst op het systematisch karakter van het 'vastleggen' van de opties inzake het ruimtelijk beleid.

\subsection{HUISVESTINGSBELEID}

Naast de bouwinitiatieven in de privé-sektor wordt er ook van overheidswege een belangrijke inspanning gedaan om het aanbod binnen het stedelijk grondgebied op te voeren en af te stemmen op de differentiatie in de vraag. Drie instanties zijn hierbij betrokken :

\subsubsection{Projekten door de stad Kortrijk ZELF uitgevoerd}

- Projekt in het B.P.A. St. Denijseweg - De stad verkoopt hier percelen voor villabouw, met onmiddellijke bouwverplichting.

- Projekt in het B.P.A. Lange Munte. De stad bouwt hier 66 atriumwoningen en 28 woningen met verdieping. Formule : belofte van aankoop.

- Projekt in het B.P.A. St. Cornelisweg. Hier worden een zestigtal woningen gebouwd in de $\mathrm{zg}$. middenklasse.

Bij deze drie projekten mikt de stad duidelijk op de middenkategorie van nieuwbouwgegadigden : gezinnen die wellicht niet (meer) in aanmerking komen voor sociale woningbouw en die men toch binnen de stadsgrenzen wil houden met een aantrekkelijk en gedifferentieerd aanbod. Dit initiatief moet dan ook als komplementair gezien worden t.a.v. de beide andere publieke instanties die zich inlaten met woningbouw. Het is tevens een poging om suppletief en zelfs korrigerend op te treden t.a.v. het privé-initiatief, in de richting van een ruimtelijk-verantwoorde inplanting en een sociaal-aanvaardbare prijs (prijsdrukkend effekt).

\subsubsection{Projekten van de S.M. 'Goedkope woning'.}

Sinds 1968 werden een 950-tal woongelegenheden gekreëerd, gaande van flats in hoogbouwprojēkten tot éêngezinswoningen.

Het spreekt vanzelf dat in het kader van deze sociale woningbouw prioritaire kansen gegeven worden aan bejaarden, gehandikapten, bewoners van te slopen woningen, enz. In alle projekten zijn dan ook woongelegenhe- 
ren special afgestemd op de minder-validen.

1.2.3. Projekten van de C.O.O.

Fooxal te vermelden in een Flatgebonw aan het "Plein" (70 woongelegen heden) dat zich bijzonder, doch niet exklisief, richt tot alleenstanden en de $z g$. "uitgebloeide getimen". Een tweede flatgebow is geprom jekteerd. Her aandeel van de flats tegenover de rradirionele woningen gat dus ook in de sociale woningbow in stijgende lijn. Dit beantwoordt aan de toegenomen vraag in een stedelijke omgeving en werke de difrerentivite van het aanbod in de hand.

\begin{tabular}{l|r|r|r|r}
\hline Bouwdossiexs & 1968 & 1969 & 1970 & 1971 \\
\hline $\begin{array}{l}\text { Woonhuizen } \\
\text { Appartementsgebouwer }\end{array}$ & 139 & 77 & 44 & 51 \\
\hline $\begin{array}{l}\text { Woongelegenheden in deze } \\
\text { appartementsgebouwen }\end{array}$ & 13 & 19 & 13 & 8 \\
\hline
\end{tabular}

Desondarks hebben al deze projekten de bevolkingskurve nog niet it posi-w tieve zin doen omslaz. In eenverdere tase van realisarie is dit thellicht wèl haalbaax.

\subsection{SANERTNGSBELEID}

Zoals alle histowische steden heef Kortrijk as te rekenen mec enkele koncentraties van onbewoonbare, ongezonde of bouwra11.ge woningen. sinds twintig jaawordt een ernstige inspanning gedan on deze problematiek systematisch en global te benaderen. Zo werden 683 woningen onbewoonbarr verklaard, warvan ex 517 ook effektef gesloopt werden. Daarenboven werden 268 woningen bij Koninklijk of Ministerieel Besluit als ongezond erkend, warvan ex 234 gesloopt werden. De 3 tad nam hierw van het merendeel der kosten voor haar rekening. Ook in 1974 is nog 7 miloen $F$, voorzen voor deze sektor. Het stadsandeel hierin bedragk 3,3 miljoen $\mathrm{F}$.

De saneringsprojekten zijn echter nier enkel omvangrijk mas spelen ook 
een rol in de ruintelijke vormgeving van de binnenstad. In her ene gevall wordt de vrijgekomen ruimte aangewend voor woningbouwprojekten, in andere gevallen kan gedacht worden aan groen- of parkeerzones, en bijna steeds bestat de mogelijkheid korrekties an te brengen in het straterplan.

\section{4. STADSKERNVERN IEUWING}

Onder deze vxij recent geintroduceerde noemer kan men de inspanmingen bundelen die de globale renovatie van de binnenstad op het oog hebben. Het gaat hier om een overheidstak bij uitstek, ofschoon het stadsbem sturur nu eens als ordenende, dan weer als koordinerende instantie hierbij betrokken is. Het volstat immers niet planen te ontwerpen en bestemingen vast te leggen. In dialoog met het Rijk zullen o.m. de restauratie van historisch waardevolle gebowen, de herstrukturering van het wegennet en de verkeersstroom, en de lokatie van de gedekoncentreerde rijksdiensten cer sprake moeten komen. Met de stedelijke middenstandsorganisaties zal het valoriseren van de kommerciele funkties aan de orde zijn, met de partikuliere eigenaars de toekomstige bestemming van hun grondstuk. Vanwege de taltijke gebouwen die tot haar patrimonium behoren. is de stad bij dit alles ook als eigenar betrokken.

Op korte of middellange termijn is het verkeersvrij maken van de city een eerste prioriteit. Dit proces werd reeds op gang gebracht en zal zich over een paar jaren over 10 straten witstrekken. Op Iangere termijn denkt men vooral an het valorizexen van het "hart" van de stad, de zone nl. rond de hoofdkerk. De historisch-watudevolle gebouren zoll Ien aangewend worden voor kulturele doeleinden (o.a. bibliotheek), de tuinen opengesteld voor het publiek en de wardeloze bowwerken verwijom derd. Het spreekt vanzelf dat deze opties bijzonder zware financiele implikaties hebben zodat ze slechts geleidelijk gerealiseerd kmnen worden. De termen warin de stadsrenovatie benaderd wordt, aijn voor on beleidsanalyse echter reeds relevanc.

Overigens start op de begroting voor 1974 een bedrag van 5 miljoen F'. specifiek toor deze runkie ingeschreven. 
In tegenstelling tot de meeste gemeenten uit het arrondissement doet de stad Kortrijk geen beroep op de diensten van de interkommunale voor streekontwikkeling 'Leiedal' voor de planning en de vormgeving van diverse projekten met sociaal-ruimtelijke inslag. Dit wordt uiteraard verklaard door de flink uitgebouwde en kompetente eigen urbanistische en technische diensten. In breder perspektief is het echter signifikant dat deze 'taakverdeling' binnen het arrondissement geen eenheid in visie en beleid warborgt. Ondanks de ingebouwde vertegenwoordiging van de stad is deze interkommunale in hoofdzaak naar de rand gericht. Zij vormt dan ook geen alternatief voor een supra-kommunale instantie die het ruimtelijk beleid in een globale visie kan benaderen en behartigen.

2. Milieubeleid

\subsection{GROENVOORZIENINGEN}

Als meest relevante realisaties sinds 1968 zouden we kunnen aanstippen :

- Groenaanleg in het kader van het sport- en speelplein, gelegen op het grondgebied van de gemeente Heule. Een investering van 7 miljoen F.

- Het Gebroeders van Raemdonckpark (10 ha) in het kader van het woningbouwprojekt en B.P.A. 'Drie Hofsteden'. Er werden tevens speelvelden en een visvijver aangelegd. De staat droeg de helft van de investering : 13 miljoen $\mathrm{F}$.

- Heraanleg Kon. Astridpark (4 ha.) - 4,5 miljoen F.

- Aanleg van diverse groene oppervlakten, verspreid over de stad, in totaal 2,5 ha. : 2,5 miljoen $\mathrm{F}$.

- Groenomkadering van de Hallen - 5 ha.

- Aanleg van 16 ha. jong bos aan de autoweg $E 3$.

Deze realisaties wijzen op een reële aandacht voor de aktieve en passieve rekreatiekansen die het stadsmilieu moet kuninen aanbieden. Hierti t: zowel gedacht aan de bescheiden plantsoenen in de onmiddellijke woonom-geving als aan de groenreserves voor de toekomst. Een groencomité bestaande uit deskundigen, adviseert de overheid in dit verband. 


\subsection{WATERZUIVERING EN HUISVUILVERWERKING}

Sins 1969 worden deze taken in interkommunaal verband behartigd door de Maatschappij voor Openbare Gezondheid van het Gewest Kortrijk (I.M.O.G.). Het Kortrijkse stadsbestuur heeft sterk aangestuurd op deze samenwerking en de eigen technische dienst bij de voorbereidende werkzaamheden ingeschakeld. Momenteel zijn 14 gemeenten aangesloten, die een bevolking van 140.000 personen vertegenwoordigen. De zuiverings- en verwerkingsinstallaties worden op het grondgebied van de gemeente Harelbeke gebouwd.

De interkommunalisatie van de waterzuivering vindt thans plaats onder sterke druk van de nationale richtlijnen terzake. De samenwerking tussen de gemeenten op het gebied van het afvoeren van het water is daarom echter nog niet verzekerd. Meestal wordt wel in onderling overleg een pragmatische, kuratieve oplossing gevonden voor de oververzadiging, zo bv. i.v.m. de Markebeek die het water van de nieuwe wijk Rodenburg (grondgebied Marke) naar Kortrijk doet afvloeien. Het spreekt echter vanzelf dat de beheersing van de waterhuishouding het gemeentelijk niveau overstijgt en een volwaardig milieubeleid om een bredere benadering en bevoegdheid vraagt.

3. Socio-kulturele beleidssfeer

\subsection{SPORTBELEID}

Zeer veel aandacht gaat naar de zwemakkomodatie. Naast het open stedelijk zwembad en het overdekt provinciaal zwembad, is er thans een overdekt zwembad in opbouw in het zuiden van de stad (stadsaandeel : 15 miljoen) er wordt er een gepland tegen 1976 in de city zelf, $n 1$. in de renovatiezone. Het sport- en speelplein op het grondgebied van Heule werd reeds vernoemd. In het kader van het woningbouw-projekt 'Drie Hofsteden' komen sportvelden klaar, terwijl bij het zwembad KortrijkZuid een sporthal wordt opgetrokken. In het uiterste Zuid-Oosten zijn voor 1976 nogmaals een sporthal en -terrein geprogrammeerd. 
Op 4 punten in de stad (en op 5 andere gepland) werden $\mathrm{zg}$. 'ravotteplaatsen' ingericht. Het zijn speelpleinen voor de jeugd in de onmiddellijke woonomgeving .

Uit deze summiere opsomming blijkt het belang van de overheidsinspanning, maar ook de optie deze infrastruktuur zoveel mogelijk te spreiden met het oog op een optimale toegankelijkheid. Het stedelijk sportcomité wordt reeds 23 jaar bij de verwerkelijking van het sportbeleid betrokken.

\subsection{KULTUURBELEID}

Kortrijk beschikt over een waaier van kulturele voorzieningen die zowat alle sinds 1968 aanzienlijk uitgebreid of vernieuwd werden. De stadsschouwburg (in 1968 gemoderniseerd) trekt naargelang de aard van de voorstelling een publiek aan dat a rato van 50 tot $75 \%$ niet uit de stad afkomstig is. In 1969 werd dit komplex verruimd tot een kultureel centrum door de uitbouw van drie tentoonstellingszalen, een balletzaal en het arenatheater. Stadsaandeel in deze verruiming : 26 miljoen $F$. De bibliotheek (nieuwbouw uit 1964) kreeg intussen een filiaal in een flatgebouw van het komplex 'De Drie Hofsteden', maar werd vooral uitgebreid met een diskotheek (1969) en een dia-picturatheek (1970) die veel sukses kennen : $37 \%$ der leden zijn niet-Kortrijkzanen. Ook de musea krijgen ontwikkelingskansen. Naast het stedelijk museum ontstond er in 1969 een oudheidkundig streekmuseum in de Broeltorens, terwijl er thans geijverd wordt voor een vlasmuseum. Op de begroting voor 1974 zijn 5,5 miljoen voorzien voor dit $\mathrm{zg}$. national initiatief dat in feite grotendeels stedelijk is. Een grote boerderij en 1 ha. grond werden reeds aangekocht. Tenslotte vermelden we de bekende Hallen, in 1966 opgericht als polyvalente ruimte voor kongressen, massa-vergaderingen en kommerciële manifestaties. Op de begroting voor 1974 is een bedrag van 35 miljoen $F$. ingeschreven voor de overname van een nieuwe hall. Ietwat in de marge van het kultureel beleid in de strikte zin van het woord staan de tekenakademie ( $48 \%$ leerlingen uit de randgeneenten) es het muziekconservatorium ( $1 / 3$ is niet uit de stad afkomstig). Dit laatste wordt thans herbouwd, hetgeen vanwege de stad een investering vraagt van 30 miljoen $\mathrm{F}$. In het kader van de stadskernvernieuwing wordt er vanzelfsprekend aandacht geschonken aan de restauratie van historisch- 
waardevolle komplexen en geïsoleerde gebouwen. Bovenaan op het 1 ijstje staat de restauratie van het begijnhof in het hart van de stad.

In het kultuurcomité gaan de vertegenwoordigers van het verenigingsleven de dialoog aan met het stadsbestuur, o.a. in verband met de betoelaging van de socio-kulturele aktiviteiten.

De kulturele voorzieningen wegen zwaar door op de begroting van een centrum-stad. De randgemeenten staan wel klaar om van deze voorzieningen te genieten, maar niet om ze mee te helpen dragen. Kortrijk vond dan ook geen gehoor bij haar poging deze sektor te interkommualiseren.

\subsection{JEUGDBELEID}

De meest opvallende optie is hier de aankoop van het St. Gabriëlinstituut om het om te bouwen tot een polyvalent centrum voor jongeren (investering van 24 miljoen F.) Er zal een jeugdherberg ingericht worden, terwijl de v.z.w. 'Groeninge' belast wordt met de vormgeving van het ontmoetingscentrum. Ondanks deze nieuwe akkomodatie kunnen jeugdtehuizen en -hemen verder aanspraak maken op konsekwente inrichtings- en startpremies $(100.000 \mathrm{~F})$. Aangezien echter de eerste ervaringen met deze toelagen niet zo positief werden geëvalueerd door het stadsbestuur, is het wel de vraag of deze regeling verder doorgang zal vinden.

\subsection{WELZIJNSZORG}

Deze hoofding kan misleidend werken omdat de specifieke welzijnszorg expliciet overgelaten wordt aan de C.0.0. en het provinciaal dienstencentrum. Toch vragen enkele initiatieven onze aandacht. Allereerst m.b.t. de bejaarden die op verschillende plaatsen in de stad de beschikking kregen over gezelligheidsruimte, meestal kaartershuisjes genoemd. Ook het ontmoetingscentrum 'Groeninge' zal voor hen openstaan, zodat de kontaktmogelijkheden tussen jongeren en ouderen bevorderd worden.

'Groeninge' wil ook aan gehandikapten ontmoetingsruimte bieden. Een initiatief om de gehandikaptensport op dreef te brengen kon rekenen op een startpremie van $100.000 \mathrm{~F}$.

De gezinszorg (gezinshelpsters), de kinderdagverblijven en de peutertui- 
nen worden niet rechtstreeks door de stad behartigd, wel gesubsidieerd. De gezinsraad wordt in dit verband wel om advies gevraagd, maar het stadsbestuur ziet $z$ 'n rol toch vooral subsidiair t.a.v. het privé-initiatief. Elke interferentie met de taakbehartiging door de C.0.0. wordt bovendien vermeden. Ook de jeugd, de bejaarden en de gehandikapten be schikken nu over een overlegorgaan. Hun reële invloed op de besluitvorming kon niet getoetst worden, maar is in elk geval niet in het oog springend.

\section{Sociaal-ekonomisch en infrastruktuurbeleid}

Op het einde van de vijftiger jaren bereikte het Kortrijkse een dieptepunt inzake strukturele werkloosheid. De interkommunale voor streekontwikkeling 'Leiedal' werd toen opgericht met de bedoeling industrieterreinen uit te rusten in het kader van de wetgeving op de ekonomische expansie. Twee belangrijke industriezones : Heule/Kuurne en Gu1legem/ Moorsele hebben aldus de rekonversie in de hand gewerkt. Nu de tewerk stelling minder problematisch geworden is en het er veeleer op aankomt de dynamische ontwikkeling van de streek in goede banen te leiden, is ook het takenpakket van de interkommunale gediversifieerd : naast 'uitrusting' is er nu steeds meer sprake van 'ordening'. De stad Kortrijk heeft een stuwende rol gespeeld bij het tot stand komen van de interkommunale, zonder nochtans de eigen taakbehartiging naar dit niveau door te spelen. Inzake ekonomische ontwikkeling, tewerkstelling en industriële inplanting zijn er ten andere op dit ogenblik geen prin= ritaire beleidsopties te vermelden.

De valorisering van de city-funkties van de binnenstad, o.m. de kommerciële attraktiepool voor gans het stadsgewest, staat daarentegen wel prioritair. De aanpassing van het stratennet, de reorganisatie van de verkeersstroom en het gedeeltelijk verkeersvrij maken van het centrum moeten in dit licht gezien worden. Om de binnenstad te ontlasten val. het doorgaand verkeer, wordt thans de ringweg voltooid op staatskosten De stad neemt de straten binnen de ring voor haar rekening en bouwt een $\mathrm{zg}$. city-ring uit, die vooral een vlot verkeer tot in het hart van 
de stad mogelijk moet maken.

5. Bespreking van het uitgavenpatroon

Bij gebrek aan een konfrontatie met vergelijkbare financiële gegevens voor de Kortrijkse randgemeenten, moet de relevantie van deze bespreking vooral gezien worden in een vergelijkend perspektief met het uitgavenpatroon van Leuven (1). De 8 gemeenten in de westelijke sektor van het stadsgewest lenen zich vanwege hun verschillend formaat inderdaad moeilijk tot een financiële vergelijking met de sterk ontwikkelde centrumstad. Dit is juist éen van de karakteristieken die de Kortrijkse case-study onderscheidt van de Leuvense.

Niettemin behoudt een overzicht van het Kortrijkse uitgavenpatroon zijn ondersteunende waarde t.o.v. de hoger aangehaalde beleidsprioriteiten. In de tabellen die de besteding per funktie in de gewone dienst aangeven (per inwoner en in \% van de totale uitgaven) (2), zijn nochtans niet dadelijk markante verschuivingen te noteren in de periode 1971-74 (3). De relatieve besteding voor Algemene Administratie en JustitiePolitie stabiliseert zich resp. rond 12 en $18 \%$, en dit ondanks de forse stijging in de absolute cijfers. De cesuur tussen vastgestelde uitgaven op basis van rekeningen en de begrotingsramingen moet vanzelfsprekend tot enige voorzichtigheid aanzetten bij het hanteren van deze absolute gegevens. Het aandeel van Verkeer-Wegen-Waterlopen is gekenmerkt door een meer uitgesproken tendens tot relatieve daling, nl. van $19,08 \%$ in 1971 tot $16,68 \%$ in ${ }^{8} 74$. Handel en Nijverheid dat in de niet-aangezuiverde uitgaventabel steeds rond de $5 \%$ schommelt, blijkt

(1) Cfr infra $\S 4.1 .5$. : Bespreking van het uitgavenpatroon.

(2) Cfr. bijlage $3 \mathrm{~A}$.

(3) Bij de bespreking baseren we ons op de tabel die de 'netto'-uitgaven weergeeft. 
in feite self-supporting te zijn. Volksontwikkeling en Kunst bereikte in Kortrijk reeds in 1971 een hoog peil, dat zich handhaaft (met een piek in 1973). De 'storende faktor' die de relatieve bestedingscijfers van de andere funkties vertekent $t, 0, v$. het belang van hun absolute uitgaven, is de funktie Sociale Voorzorg en Onderstand. De forse interventie ter ondersteuning van de C.0.O. (een stijging met 2,23\% tussen 1973 en 1974) wijzigt het uitgavenprofiel inderdaad in een weinig beleidsrelevante zin.

\begin{tabular}{|c|c|c|c|c|c|c|c|c|}
\hline \multirow{2}{*}{$\begin{array}{l}\text { Begroting } \\
\text { Gewone } \\
\text { dienst }\end{array}$} & \multicolumn{2}{|c|}{$\begin{array}{l}\text { Personeels- } \\
\text { kosten }\end{array}$} & \multicolumn{2}{|c|}{$\begin{array}{l}\text { Werkings- } \\
\text { kosten }\end{array}$} & \multicolumn{2}{|c|}{ Overdrachten } & \multicolumn{2}{|l|}{ Schuld } \\
\hline & Per inw. & In $\%$ & Per inw. & In $\%$ & Per inw. & In \% & Per inw & In $\%$ \\
\hline 1973 & 3.790 & 44,04 & 1.129 & 13,13 & 681 & 7,91 & 3.004 & 34,92 \\
\hline 1974 & 4.465 & 46,88 & 990 & 10,40 & 963 & 10,12 & 3.105 & 32,60 \\
\hline
\end{tabular}

Deze tussenkomst zal de kategorie der 'overdrachten' in de begroting voor 1974 sterk in gewicht doen toenemen $(+2,21 \%)$. Van deze overdrachten gaan $64 \%$ naar Sociale Voorzorg en Onderstand en slechts $12 \%$ naar de traditionele funktie Volksontwikkeling en Kunst. Dit alles neemt niet weg dat de personeelsuitgaven het leeuwenaandeel blijven opeisen $(44 \%)$ en hun impakt nog verhogen $(+2,84 \%)$. De meest personeelsintensieve funkties zijn wel :

$\begin{array}{lr}\text { Algemene Administratie (AA) } & 15,2 \% \\ \text { Justitie-Politie } & 25,5 \% \\ \text { Brandweer } & 7,6 \% \\ \text { Verkeer-Wegen-Waterlopen (VWW) } & 6,5 \% \\ \text { Onderwijs } & 17,6 \% \\ \text { Volksontwikkeling en Kunst (VO + K) } & 12,8 \% \\ \text { Ontsmetting-Reiniging-Huisvuil (ORH) } & 6,4 \%\end{array}$

De funktie Justitie-Politie valt hierbij op met een aandeel van $25 \%$, hetgeen toch in verband gebracht kan worden met de centrumfunktie van de stad.

De werkingskosten daarentegen dalen relatief en absoluut, niet zozeer in het kader van de funktie AA en VWW, maar veel markanter bij $\mathrm{VO}+\mathrm{K}$ en $\mathrm{ORH}$. De schuld tenslotte daalt weliswaar in relatieve termen $(-2,32 \%)$ als onvermijdelijk gevolg van de verschuivingen bij de personeelsuitga- 
ven en de overdrachten, maar helemaal niet in absolute cijfers. Zwaartepunten zijn hier VWW $(26,97 \%)$ en Vo $+\mathrm{K}(16,46)$, hetgeen helemaal strookt met het traditioneel patroon, maar ook Handel en Nijverheid $(14,31)$ en Huisvesting en Stedebouw $(13,21)$. In beide sektoren engageert de stad belangrijke middelen die zwaar doorwegen op het uitgavenprofiel, maar grotendeels gerekupereerd worden bij de realisatie van de projekten. Het zijn dan ook bij uitstek beleidsrelevante funkties.

Het beleidsprofiel van Kortrijk dat uit de gehele bespreking naar voor treedt, wordt in bijgaande doeleindenstruktuur uitgewerkt (1) zowel m.b.t. de initiale taakstellingen als de uiteindelijke doelstellingen, met als tussenschakel de angewende beleidsmiddelen.

\subsection{DOELEINDENSTRUKTUUR VAN DE WEST-KORTRIJKSE STADSRAND}

De acht individuele gespreksronden met de bestuurskolleges hadden als voornaamste gemeenschappelijk doel de beleidsopstelling van de Westelijke rand te verduidelijken t.o v de centrum-stad. Vandaar de poging om de voornaamste opties en doelstellingen te bundelen in een streekdoeleindenstruktuur (2). Deze synthese kan uiteraard geen weergave zijn van de individuele klemtonen en schakeringen, en vervangt dan ook in genen dele de acht gemeertelijke doeleindenschema's. Voor een beter begrip van de agglomeratieproblematiek zijn het niettemin de gemeenschappelijke krachtlijnen die verhelderend zullen werken.

Een gedetailleerde kommentaar heeft weinig zin aangezien de schema's voor zichzelf spreken (3).

Twee beleidssferen zouden we nochtans in reliëf willen brengen aangezien ze in elk der acht gemeenten een prioritaire aandacht krijgen. Allereerst zijn de gemeentebesturen bekommerd om het huisvestingsaanbod. Via

(1) Cfr. de separate opbergmap met de doeleindenschema's.

(2) Cfr. de separate opbergmap.

(3) Aan de top van de doeleindenstruktuur wordt hier het onderscheid gemaakt tussen hoofddoeleinden en beleidsprioriteiten. Aangezien deze laatste term ook op een onmiddellijke taakstelling kan wijzen, werd hij voor alle duidelijkheid in de verdere onderzoeken vervangen door 'uiteindelijke doeleinden'. 
de bouwmatschappijen, de interkommunale of in eigen beheer (Moorsele bv.), wordt een belangrijke inspanning gedaan om een veelzijdige waaier van woongelegenheden ter beschikking te stellen. Het kwantitatieve aanbod wordt opgedreven maar de aandacht van overheidswege voor de middenen hogere woningbouwkategorieën is al even opvallend. Het is de gemeentebesturen niet enkel om sociale woningbouw te doen ten behoeve van de autochtone bevolking, maar al evenzeer om de gemeentelijke expansie in het kader van een sterk groeiend stadsgewest.

Afgestemd op deze woonfunktie is de aandacht voor de beveiliging en verfraaiing, in êén woord : de leefbaarheid van het woonmilieu. Het overheidsinitiatief zal zich in dit verband echter toespitsen op de sociokulturele infrastruktuur, speciaal dan de sportakkomodatie. Het aanbod is zeer ruim : van speelpleinen in de wijken tot specifieke sportterreinen, zowat overal een sporthal, en uitzonderlijk zelfs een zwembad. De kulturele infrastruktuur is daarentegen minder ontwikkeld. Een paar initiatieven zijn geprojekteerd of in uitvoering, maar de meeste gemeenten zien hun taak in dit verband als duidelijk suppletief $t . a, v$. de goed uitgebouwde voorzieningen vanuit de parochie en/of de arbeidersbeweging. Het overheidsbeleid is in de hele welzijnssfeer dan ook als 'aanvullend" te omschrijven, ook al stellen drie gemeenten (Marke, Moorsele en Wevelgem), zich meer koördinerend of zelfs integrerend op.

Het sociaal-ekonomisch beleid is daarentegen letwat op de achtergrond geraakt, wellicht sinds de rekonversie van de vijftiger jaren met sukses bekroond werd. De gemeentebesturen hebben deze sektor in belangrijke mate toevertrouwd aan de zorgen van de interkommunale Leiedal. Deze latste speelt ook een bemiddelende rol bij het opmaken van de B.P.A.'s en de ruimtelijke ordening in het algemeen, zodat haar koördinerende funktie in streekverband niet te onderschatten is. Wellicht is mede daardoor een zekere koherentie in het huisvestings- en infrastruktuurbeleid aan te wijzen.

\subsection{DOELEINDENSTRUKTUUR VAN STAD EN RAND IN PERSPEKTIEF}

Komplementair bij de social-geografische benadering van het agglomeratiefenomeen, zijn er ook vanuit een "overlay" van de Kortrijkse stads- 
en de West-Kortrijkse rand-doeleindenstruktuur indikaties af te leiden met het oog op een eventuele bestuurlijke herstrukturering.

Een eerste vaststelling heeft betrekking op het stedelijk huisvestingsbeleid. Via een uitgesproken planmatige approach (struktuurplan, B.P.A.'s) wordt niet enkel de bestemming der gronden vastgelegd, maar worden tevens reserves aangelegd voor de toekomst. Ondanks de sterke bouwinspanning kan de stadsbevolking nochtans niet op peil gehouden worden, hetgeen een risico insluit voor de toekomstige (financiële) mogelijkheden van de stad. Deze wordt immers met zware investeringen inzake renovatie van de binnenstad gekonfronteerd, terwijl het draagvlak voor deze inspanningen versmalt en verschraalt ten voordele van de rand.

Getoetst aan de uitgesproken prioriteit van de rand m.b.t. de gemeentelijke expansie via een intensieve bouwpolitiek, ligt de inkonsekwentie in agglomeratie- en stadsgewestelijk verband voor de hand. Stad en rand staan konkurrentieel tegenover elkaar, hetgeen niet alleen niet billijk is t.o.ve de zware lasten die de stad vanwege haar centrumfunktie te dragen heeft (1), maar bovendien niet verantwoord kan worden qua ruimtelijk ontwikkelingsperspektief. Een inplanting van belangrijke huisvestingsprojekten in de rand, niet zozeer ter onmiddellijke bevrediging van de plaatselijke noden maar veeleer als respons op de huisvestingsbehoeften van het stadsgewest als geheel, dient vanzelfsprekend ook in dit ruimer geheel behartigd te worden en gestalte te krijgen om de noodzakelijke planologische eenheid in het ruimtelijk beleid te waarborgen. Dit geldt allereerst voor de gemeenten die als voornaamste doelstelling de uitbouw van de residentiële funktie vooropstellen (bv. Marke). Juist door deze affirmatie geven ze impliciet hun betrokkenheid bij het agglomeratie-verschijnsel toe, betrokkenheid die op het bestuurlijke vlak doorgetrokken zal moeten worden via een volledige of partiële integratie (bv. een verplichte inter- of suprakommunale behartiging van het ruimtelijk en huisvestingsbeleid).

Ook t.a.v. andere beleidssferen brengt een vergelijking van de doeleindenstrukturen een noodzakelijke koncertatie der inspanningen aan het

(1) Cfr. de studie Regionale Steden van het Vervolmakingscentrum voor Bedrijfsleiding en Administratie : "Probleemstelling en diagnose met behulp van financiële instrumenten" - Leuven, 1973. 
1icht. Een onvoldoende onderkende konsekwentie van de uitbouw van woonzones is bv, de afwatering en waterzuivering. Waar een markante overlast of hinder vastgesceld worden, slaagt men er wel in een ad hoc oplossing uit te werken tussen de betrokken gemeenten (1), maar deze post factumpolitiek kan onmogelijk volgehouden worden. Evenzeer kontrasterend is de strijd tegen de milieuhinder die in de centrum-stad gevoerd wordt, terwijl de randgemeenten amper restriktieve matregelen opleggen, of althans niet in staat zijn deze via een effektieve kontrole te doen naleven. In deze domeinen ligt een verregaande samenwerking, bv. in ruim stadsgewestelijk verband, zonder meer voor de hand.

Evenals in de rand is ook te Kortrijk de socio-kulturele beleidssfeer sterk ontwikkeld. Het meest opvallend onderscheld is evenwel het nagenoeg ontbreken van gemeentelijke kulturele infrastruktuur in de rand, terwijl de specifiek kulturele voorzieningen te Kortrijk juist in reliëf staan : een veelzijdig kulcureel centrum, musea, bibliotheken, diskotheken, maar ook het goed uitgebouwde kunstonderwijs. Zoals aangestipt bij de bespreking worden deze voorzieningen in belangrijke mate door de randgemeenten benut, zonder dat hiervoor een andere dan partikuliere bijdrage aangeboden wordt. Sterker nog, de aanwezigheid van bepaalde kulturele voorzieningen in het centrum ontslat de randgemeenten tot op zekere hoogte van gelijkaardige investeringen op eigen territorium, zodat alle aandacht in deze beleidssfeer naar de sportakkomodatie kan gaan. De analyse van de doeleindenstruktuur reveleert op deze wijze niet alleen de bekende onbillijkheid in de verdeling der lasten van de centrumfunktie, maar bovendien een zekere eenzijdigheid in de beleidsontwikkeling van bepaalde randgemeenten In de mate dat deze eenzijdigheid meer manifest is, $11 j k t$ ook de beleidsbetrokkenheid of -komplementariteit van stad en rand evidenter, en kunnen hieruit konklusies getrokken worden voor een grotere bestuurlijke integratie.

Het doeleindenonderzoek is vanuit deze vaststellingen nochtans niet geëigend om precieze grenzen te bepalen voor eventuele bestuurlijke samenwerkingsverbanden of samenvoegingsformules. Hierbij blijven de morfologische indikaties toonaangevend. De algemene oriëntatie van deze herstrukturering, zowel wat de territoriale dimensie betreft als wat de materie aangaat die prioritair voor schalverruiming in aanmerking komt, kan echter zinvol medebepaald worden vanuit een beleidsanalyse.

(1) Bv, tussen Kortrijk en Marke $1, v \circ m$. de Markebeek. 
FIG.: 2.1

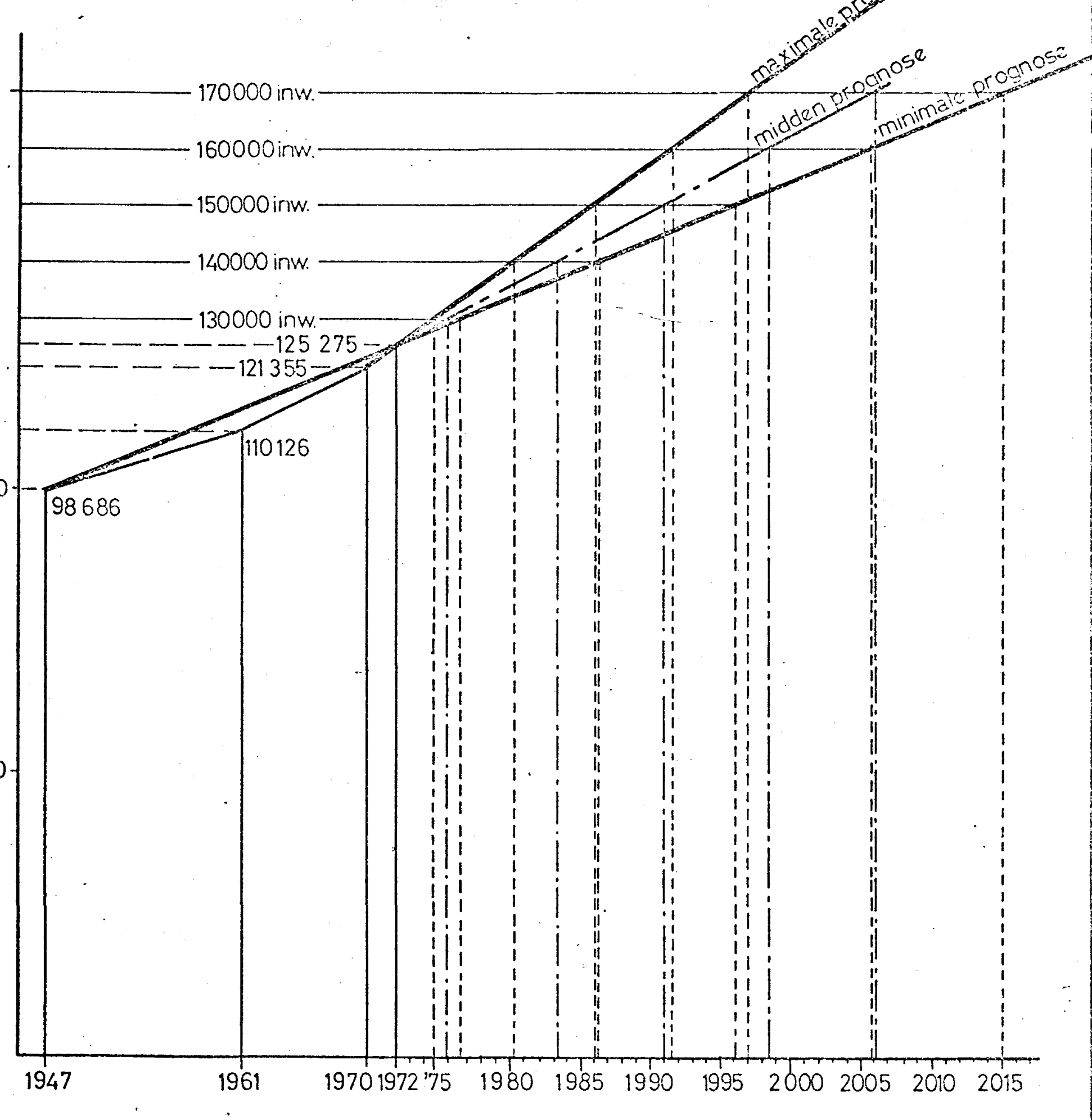


FIG:2.3

BEVOLKINGSAANGROEI $1951-1970$ 1.0.

de AANGROEI 1947-1970

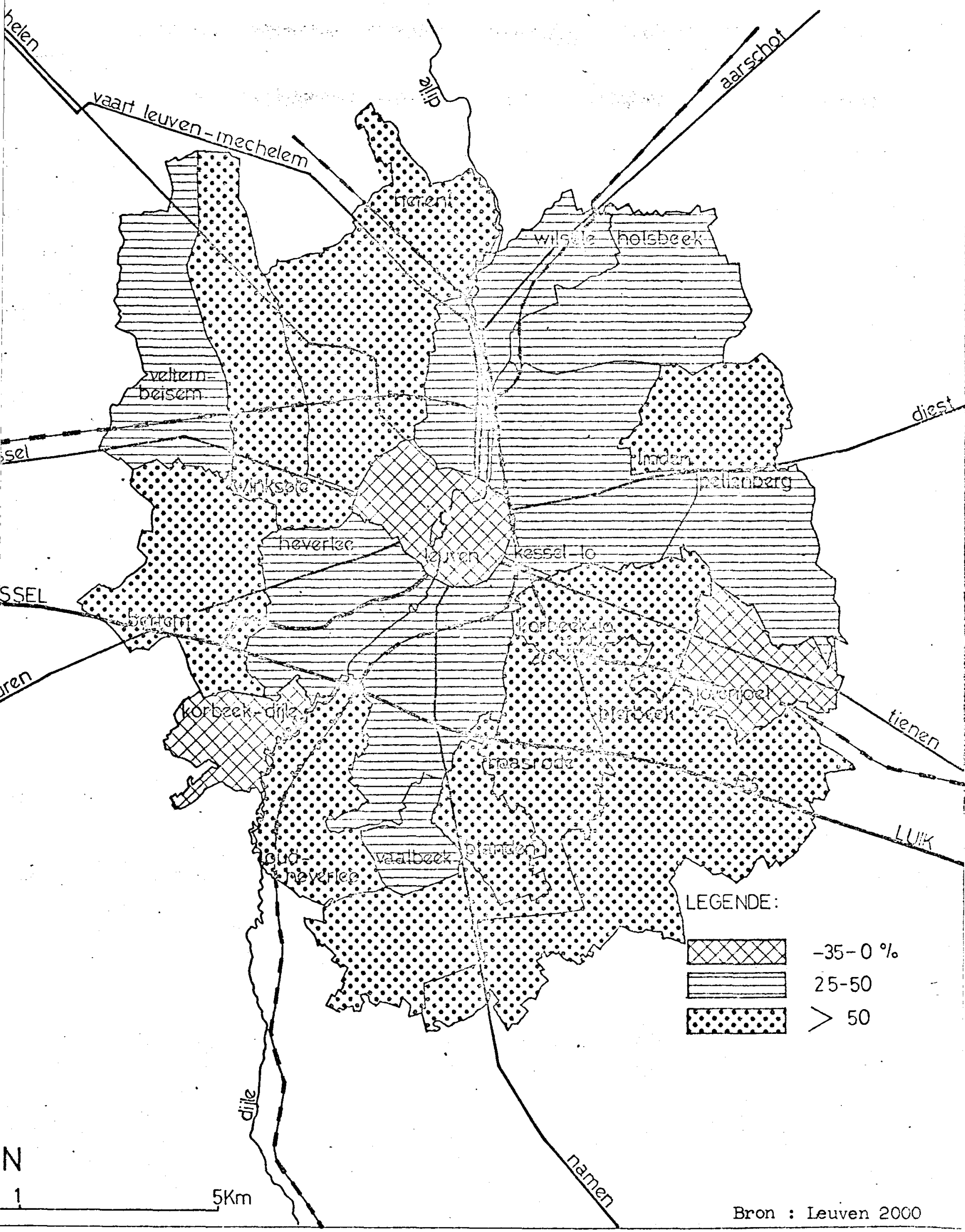


Voor een koherent beeld is vanzelfsprekend een benadering van de agglomeratie als geheel vereist, hetgeen in de Kortrijkse case-study omwille van de beperkte mogelijkheden van de onderzoeker niec gerealiseerd kon worden. De bevindingen zijn dus enkel ondersteunend $t, a, v$, de onderzoeksresultaten uit de andere deelstudies. In een andere agglomeratiekontekst, $\mathrm{nl}$, de Leuvense waarin de randgemeenten geselekteerd konden worden op basis van hun relevantie en representativiteit, hopen we de onderzoeksresultaten duidelijker te operationaliseren in het licht van de schaalvergrotingsproblematiek.

$\S 4$. Doeleinden-onderzoek van de Leuvense agglomeratie

Sinds het Leuvens stadsbestuur, verschillende randgemeenten, de Interkommunale voor streekontwikkeling Interleuven en de Universiteit de handen in elkaar hebben geslagen om een doorlichting te maken van stad en stadsgewest, is het Leuvense één der best gekende stedelijke koncentratiegebieden in ons land. De studie 'Leuven $2000^{\prime}$ verwijst bovendien naar de toekomst. Op basis van de huidige gegevens worden prognoses gemaakt $m \cdot b, t$. de te verwachten ontwikkelingen, om hierop de renovatie en de uitbouw van de centrum-stad af te stemmen. Het Leuvense kader vormt dan ook een bijzonder dankbaar terrein voor een analyse van de doeleindenstruktuur. De onderzoeker kan niet alleen beroep doen op ondersteunend feitenmateriaal, maar de beleidsverantwoordelijken - vooral in de centrum-stad - staan ook open voor een toekomstgerichte dialoog.

Ter introduktie van de beleidsbespreking kunnen enkele basisgegevens over de Leuvense agglomeratie-situatie aangestipt worden. De stad Leuven is omgeven door 6 randgemeenten (Herent, Heverlee, Kessel-Lo, Korbeek-Lo, Wilsele en Winksele) die samen de agglomeratie vormen. Het ommeland dat door de centrum-stad gepolarizeerd wordt, het $\mathbf{z g}$. stadsgewest, is heel rat ruimer en besiat nog 12 andere gemeenten. Op bijgaande kaarten is de bevoikingsaangroei in het stadsgewest overzichtelijk weergegeven, alsook de prognose die de huidige 130.000 inwoners tegen de eeuwwisseling uit ziet groeien tot een bevolking van 170.000 inw. Het Leu- 
vense is inderdaad een groeiend gewest :

\begin{tabular}{l|c|c|c|c}
\hline Gemiddelde jaarlijkse groeicijfers & \multicolumn{2}{|c|}{$947-196 i$} & \multicolumn{2}{|c|}{$1961-1970$} \\
\cline { 2 - 5 } voor het Leuvense en het Rijk (in \% $)$ & Leuvense & Rijk & Leuvense & Rijk \\
\hline Natuurlijke toename & 4,5 & 4,9 & 5,5 & 3,6 \\
Migratorische toename & 3,4 & 0,6 & 5,4 & 1,8 \\
Totale toename & 7,9 & 5,5 & 10,9 & 5,4 \\
\hline
\end{tabular}

Deze groei ligt echter niet evenwichtig gespreid over stad en rand. Meer specifiek voor Leuven en de [wee onderzochte randgemeenten, sLe]len we uiteenlopende trends vast in de bevolkingsevolutie. Leuven kent. nog wel een positief naturiijk saldo, maar daarnaast een sterk negaticf migratiesaldo, waardoor meteen een der cruciale problemen van de twekomstige ontwikkeling van de centrum-stad aangeraaki is (i).

Inzake tewerksteling in het stadsgewest konkludeert de studie Leuven 2000 : "De toename van de tewerksteliing in de 19 gemeenten staat praktisch uitsluitend op nam van de tertiaire sektor, terwijl de sekundaire sektor stagneert en de primaire sektor sterk achteruitgaat. Ruimtelijk zijn er grote verschilien : de overgrote meerderheid van de terciaire tewerksteiling is in Leuven stad te situeren, terwiji de randgemeenten een groeiend aandeeî van de sekundaire sektor krijgen; in de overige gemeenten gat de totale tewerksteliing slechis licht vooruit : de grote afname van de primaire tewerkstelling wordt er wel gekompenseerd door een toename van de sekundaire en tertiaire sektor, doch de totale groei is minder groot dan in het gehele stadsgewest. Dit laatste procts, dat zich reeds van vóbr het laatste decennium voltrekt, en zich tevens voortzet voorbij de grenzen van het stadsgewest in het pendel-hinterland, doet een groeiende pendelbeweging ontstaan die mede oorzaak is vain de verkeersproblemen in en rond de binnenstad." (2)

(1) Cfrobijgaande tabeilen.

(2) Studie 'Leuven 2000": De globaie tewerkstelingssituatie. 
BEVOLKINGSEVOLUTIE 1947-1972

\begin{tabular}{|c|c|c|c|c|c|c|c|}
\hline & \multirow[b]{2}{*}{ Bevolking 1947} & \multirow[b]{2}{*}{ Bevolking 1961} & \multirow{2}{*}{ Bevolking 1972} & \multicolumn{2}{|c|}{ evolutie $47-72$} & \multicolumn{2}{|c|}{ evolutie $6 \mathrm{l}-72$} \\
\hline & & & & absoluut & $\%$ & absoluut & $\%$ \\
\hline Herent & 8.340 & 8.979 & 11.185 & 2.845 & 34,11 & 2.206 & 24,57 \\
\hline Kesse1-Lo & 14.048 & 20.098 & 23.684 & 9.636 & 68,59 & 3.586 & 17,84 \\
\hline Leuven & 36.640 & 32.524 & 31.083 & -5.557 & $-15,16$ & -1.441 & $-4,4$ \\
\hline
\end{tabular}

NATUURLIJKE EN MIGRATIESALDI 1947-1961 en 1961-70

\begin{tabular}{l|c|c|c|c|c|c|c|c|c|}
\hline & $\begin{array}{l}\text { Natuurlijk saldo } \\
47-61\end{array}$ & $\%$ & $\begin{array}{l}\text { Natuurlijk saldo } \\
61-70\end{array}$ & $\%$ & $\begin{array}{l}\text { Migratiesaldo } \\
47-61\end{array}$ & $\%$ & $\begin{array}{l}\text { Migratiesaldo } \\
61-70\end{array}$ \\
\hline Herent & +484 & $+5,80$ & +413 & $+4,60$ & +603 & $+7,23$ & +1235 \\
Kessel-Lo & +1714 & $+12,20$ & +1793 & $+8,92$ & +4336 & $+30,87$ & +1213 & $+13,75$ \\
Leuven & +437 & $+1,19$ & +554 & $+1,70$ & -4553 & $-12,43$ & -2455 \\
\hline
\end{tabular}


TEWERKSTELLING IN HET LEUVENSE STADSGEWEST 1970

\begin{tabular}{|c|c|c|c|c|c|c|}
\hline & \multicolumn{2}{|c|}{ Primaire sektor } & \multicolumn{2}{|c|}{ Sekundaire sektor } & \multicolumn{2}{|c|}{ Tertiaire sektor } \\
\hline & Absol. & $\%(1)$ & Absol. & $\%$ & Absol. & $\%$ \\
\hline Leuven & 49 & 0,19 & 6.583 & 25,47 & 19.519 & 74,64 \\
\hline Herent & 99 & 3,31 & 1.915 & 64,05 & 976 & 32,64 \\
\hline Heverlee & 135 & 1,52 & 4.394 & 49,60 & 4.329 & 48,87 \\
\hline Kesse1-Lo & 56 & 1,99 & 928 & 32,10 & 1.902 & 65,79 \\
\hline Korbeek-Lo & 25 & 3,57 & 289 & 41,23 & 387 & 55,21 \\
\hline Wilsele & 53 & 2,08 & 1.712 & 67,35 & 777 & 30,57 \\
\hline Winksete & 117 & 27,53 & 148 & 34,82 & 160 & 37,65 \\
\hline Agglomeratie & 534 & 1,20 & 15.969 & 35,84 & 28.055 & 62,96 \\
\hline $\begin{array}{l}\text { Overig } \\
\text { stadsgewest }\end{array}$ & 570 & 14,74 & 1.072 & 27,71 & 2.226 & 57,55 \\
\hline Stadsgewest & i 104 & 2,28 & 17.041 & 35,19 & 30.281 & 62,53 \\
\hline
\end{tabular}

(1) Aandeel in de totale tewerkstelling

Qua funktionele uitrusting klasseert het V.B.S.G.-herindelingsonderzoek de gemeenten van de Leuvense agglomeratie als volgt (1):

\begin{tabular}{lc|c|c|c}
\hline & Tewerkstel ling & Medische uitrusting & Kommerc. uitrusting & Onderwijs \\
\hline Leuven & II & I & II & I \\
Herent & V & IV & V & VI \\
Heverlee & IV & IV & III & IV \\
Kesse1-Lo & V & IV & V & IV \\
Korbeek-Lo & VI & V & VI \\
Wilsele & V & V & VI & V \\
Winksède & VII & V & VIII \\
\hline
\end{tabular}

Inzake medische voorzieningen en onderwijs tilt Leuven zich op tot het niveau van de grootsteden. Het spreekt vanzelf dat de Universiteit hier aan de basis van ligt. Bovendien is Leuven ook een belangrijk centrum voor middelbaar en niet-universitair hoger onderwijs. De kommerciële uitrusting is deze van een regionale stad (cfr. Hasse1t of Mechelen), ook

(1) De gemeentelijke herindeling van Brabant - Brusse1, 1973. 
al is de attraktie beknot in de richting van Brussel en Mechelen. De invloedssfeer van de tewerksteling tenslotte strekt zich vooral uit in Oostelijke en Noord-Oostelijke richting.

Bij de situering van elk van de onderzochte gemeenten wordt nader ingegaan op hun voornaamste karakteristieken.

\section{1. DOELEINDENSTRUKTUUR LEUVEN}

\section{SITUERING}

Komplementair bij het inleidend overzicht van de Leuvense agglomeratie en ter introduktie van de beleidsanalyse, zouden we een par elementen in de ontwikkeling van de stad Leuven in het licht willen stellen die mede-verklarend kunnen zijn voor de huidige situatie. De beperkte oppervlakte (394 ha., warvan 90 ha. (het Kareelveld) slechts in 1958 werd aangehecht), het indrukwekkend monumentaal patrimonium, maar ook de zware erfenis van sterk-verouderde woonwijken zijn te verklaren vanuit het proces dat zich gedurende eeuwen binnen deze muren voltrokken heeft. Letterlijk dan, want de huidige stadsgrenzen lopen nagenoeg samen met de 'vesten", een afbakening die reeds uit de veertiende eeuw dateert. Toen moesten nieuwe muren de wallen uit de $12 \mathrm{e}$ eeuw vervangen, omdat Leuven geen blijf meer wist met haar 20.000 inwoners. De ontwikkeling als universiteitsstad (sinds 1425), de industriële revolutie, noch de bevolkingskoncentratie in en rond deze groeipool inzake tewerkstelling in de sekundaire en tertiaire sektor, hebben de administratieve omschrijving van de stad nog kunnen wijzigen.

Dat deze situatie niet onverdeeld positief uitvalt voor de centrum-stad blijkt reeds uit de bevolkingskurve. Sinds de eeuwwisseling (42.000 inwoners) daalt deze gelijkmatig tot het huidig peil : 31.100 inwoners. De kwalitatieve verschuivingen die hiermee gepaard gaan hebben dit probleem een additionele dimensie gegeven die men sinds enige tijd in termen van "leefbaarheid" benadert. Duidelijker nog dan in minder uitgesproken historische steden overstijgt de agglomeratieproblematiek in het Leuvense inderdaad de intern-bestuurlijke reorganisatie. De optimale behartiging van een aantal cruciale welzijnstaken staat hier ter diskussie. 
1. Grond- en woonbeleid

\subsection{GRONDREGIE}

De meest markante innovatie in deze beleidssfeer is de oprichting van een stedelijke regie voor grond- en huisvestingsbeleid in 1971 , verder kortweg "grondregie" genoemd. Dit soepel beleidsinstrument staat vooral in het teken van de huisvesting. Leuven wil resoluut een verdere ontvolking afremmen en streeft integendeel naar een optimum van 40.000 inwoners. Deze prioriteit zal een weerslag hebben op diverse sektoren van het stadsbeleid, maar is op de eerste plaats merkbaar in de bouwinspanning. De grondregie is dan ook niet zozeer gericht op het reserveren naar de toekoms $\tau$ toe van voordelige en gunstig gelegen gronden, als wel op het verwerven en/of verkopen van terreinen voor bouwinitiatieven op korte en middellange termijn.

Ondanks het feit dat één derde van de beschikbare stadsgronden afgestaan moest worden voor de realisatie van de ring rond Leuven (1) konden toch een paar opmerkelijke projekten opgezet worden. De stedelijke grondregie speelt hierbij vooral een bemiddelende en regelende rol. Ze stelt de grondstukken ter beschikking en bepaalt de aard van de bebouwing, zonder zelf als bouwheer op te treden. Voor deze funktie acht de stad zich niet voldoende technisch uitgerust. Hiervoor wordt dan ook een privé-architektenbureau aangesproken in kombinatie met een privé-bouwonderneming. Binnen het raam van de architektonische indikaties die de stad geeft, bouwen de promotors hun projekten uit, die ze verder rechtstreeks of via de grondregie aan de man brengen. In tegensteling tot de zg. sociale woningbouw worden deze woongelegenheden enkel verkocht, en niet verhuurd. De prijs kan door dit procédé echter gevoelig gedrukt worden $t, a, v$, soortgelijke initiatieven in de privé-sektor. In totaal gaat het (medio 1974) om een 250-tal woongelegenheden. In een tweede faze wil men deze bouwinspanning resoluut verder zetten.

(1) Zie verder onder 3.2. : verkeersontsluiting. 
Om de grondregie in staat te stellen gronden en eigendommen te verwerven, werden sinds 1970 leningen opgenomen door de stad voor een totaal bedrag van 48 miljoen $F$. Hierbij is nog niet de aankoopsom verrekend $\left(6,3\right.$ miljoen F.) van 20 studio $^{\prime s}$ in de Fonteinstraat, een initiatief dat in 1972 genomen werd om de gezinnen op te vangen uit de meest urgent te saneren wijk. Op de begroting voor 1974 staat nogmaals een bedrag van 12 miljoen $F$. ingeschreven als kredietverlening aan de regie. Het verwerven van terreinen kan dus systematisch worden verdergezet in het licht van de opties van het ruimtelijk beleid.

\subsection{PLANNEN VAN AANLEG}

In het verleden werden op een vrij traditionele wijze BPA's ontworpen voor de verschillende wijken van de stad. Meer en meer blijken deze echter als beleidsinstrument slechts te kunnen funktioneren indien ze kaderen in een totaalvisie, een algemeen plan van aanleg. Dit A, P. A . werd dan ook prioritair gesteld door de huidige bestuursploeg en zal nog in 1974 klaarkomen. De globale bouwinspanning binnen de stadsgrenzen moet door dit A.P.A. zo verantwoord mogelijk gelokaliseerd worden. Dit houdt een sanering in voor bepaalde wijken, de renovatie van de stadskern en de omschrijving van de zones die voorbehouden worden aan industriële en administratieve komplexen. Tenslotte is dit A.P.A. ook belangrijk $t, a \cdot v$, de globale verkeersinfrastruktuur.

De B.P.A."s zullen in het licht van de algemene opties soms ingrijpend gewijzigd moeten worden. Een detailbespreking is in dit verband dan ook irrelevant.

Het stadsbestuur wil de inzichten, de ervaringen en de verwachtingen van de betrokken bevolking verwerken in de definitieve vormgeving (of de herziening) van de B.P.A. ${ }^{9}$ s en de bouwprojekten in het algemeen. Naar aanleiding van de week van de huisvesting (19-29 oktober 1973) werden aldus op het stadhuis een aantal informatie- en diskussieavonden georganiseerd, waaraan naast de schepen voor ruimtelijke ordening en huisvesting en de betrokken architektenbureau's telkens ook heel wat wijkbewoners en/of toekomstige bewoners deelnamen. Een konsultatie op deze schaal is vooralsnog een eenmalig initiatief, maar wijst toch op een zekere bereidheid om de ruimtelijke planning in dialoog uit te 
werken.

Sinds 1970 werden voor nagenoeg $30 \mathrm{miljoen} \mathrm{F}$. investeringsuitgaven gedaan met uitdrukkelijke verwijzing naar de verwerkeijjking van de in de B.P.A. 's voorziene opties. Meestal gaat het echter om beperkte aankopen van terreinen ten behoeve van toekomstige projekren van openbaar nut. Het verwerven van één terrein, gelegen aan de Tiensestraju 60 , vroeg daarentegen een investering van 22 miljoen $F$. Deze hoge uilgave wordt gerechtvaardigd door de ultzonderlijk gunstige iigging mex het oog op een eventuele uitbouw van sportinfrastrukcuur, aansluitend bij de huidige zwemkom. Onder de rubriek "stedebouw" is op de begroing 1974 een lening voorzien van 5 miljoen $F$. voor urbanisatiedoeleinden, maar ook onder "Verkeer, wegen, waterlopen" is 10 miljoen $F$. voorzien voor dezelfde bestemming. Er tekenc zich dus een belangstelling á voor een meer systematische aanpak van de urbanisatieproblematiek. en meer bepaald voor de stadskernvernieuwing.

\section{3, STADSKERNVERNIEUWING EN -SANERING}

Voor alle historische steden is stadskernvernieuwing een priotilalie opgave. Hiermee wordt niet zozeer de restauratie bedoeld van histoli.: 1: waardevolle monumenten en woningen : deze inspanning wordt onder kultuil beleid besproken (cfr. 2.3.). Het gaar veeleer om een globale revalull. sering van de binnenstad. Door een koncentratie van handels-, onderw? J: en administratieve voorzieningen is de permanente bewoning ex soms adi zienlijk uitgedund ten voordele van de rand. Bovendien is een belang rijk deel van het woningenbestand verouderd of beneden peil. Dit makk de binnenstad onaantrekkelijk als woonzone. Doel van de scadskernver nieuwing zal dan ook zijn, via een geheel van maatregelen, waaronder sanering, restauratie, nieuwe woonprojekten en een evenwichtige spreiding van woonzones en voorzieningen, de city-funkiles van de stad te verzo nen met $\in$ en kwalitatief-hoogstaande woon- en werkomgeving.

Van deze algemene diagnose is Leuven wel een sprekende illustran. Enerzijds heeft zij de rijke maar ten dele ook bezwarende etienis meegekregen van haar historisch verleden. Op een beperkt territorium heeft de bewoning zich eeuwenlang gekoncentreerd. Naast het waardevol. 
patrimonium zijn echter ook een aantal woonzones overgeleverd die volstrekt beneden de hedendaagse normen izggen. Uic een rapport van het Nationaal Instituut voor de Husvesting uit 1969 blijkt bv dat $25 \%$ van de woningen onverbeterbaar of zelfs ongezond zijn.

Dit is een bijzonder zwaar bilan dac bovendien in een globale visie op de stadsproblemariek niet geissoleerd kan worden van de koncentratieverschijnselen inzake onderwijs en administratie die zich in de binnenscad voordoen. Hierbij kan men in eerste instantie aan de universiteit denken, waarvan de groep humane wetenschappen - en tot op heden ook de geneeskunde - in de binnenstad gevestigd is : een "stadscampus" dus. Daarnaast zijn er echter ook calrijke onderwijsinrichtingen voor middelbat, technisch en niet-universitair hoger onderwijs. Samen met administratieve diensten zoals deze van de Belgische Boerenbond, nemen zij een aanzienlijk deel van her territorium in beslag en veroorzaken op de spitsuren een bijzonder zware verkeersbelasting ( $i)$. Indien men hierbij de belangrijke industrievestigingen voegt, ietwat excentrisch gelegen maar toch nog binnen de stadsring, dan komt heel de komplexireit van de Leuvense stadsrenovatie duidelijk naar voor.

\subsubsection{Sanering}

In het licht van de opvallend ongunstige situatie $m \cdot b \cdot t$. de kwailiteit van het woonmlileu in bepaaide wijken, is een planmarige sanering een voor de hand liggende beleidsprioriteic. Vooxalsnog dient deze affirmatie echter met de nodige omzichrigheid gehanteerd te worden.

Her probleem is inderdaad omvangrijk. Naas de typische saneringsbuurt in de omgeving van de Riddersstraat en de Fonteinstraat, zijn er over de ganse stad "gangen" en "cités" verspreid, terwijl er ook talrijke geisoleerde krot- en ongezonde woningen aan te wijzen zijn. De financièle middelen die de stad inzet ter sanering van deze toestand zijn bijzonder beperkt. Zo werden in 1972 twee leningen aangegaan, één ter verwezenlijking van BPA Fonteinstraat $(2.175 .000 \mathrm{~F}$ ) en één specifiek voor de aankoop van krotwoningen $(\mathbb{1} .825 .000 \mathrm{~F})$. Via het verwerven van alle beschikbaar komende krotwoningen in de reeds genoemde buurt

(1) Ter illustratie slechts éên voorbeeld : Uit een verkeerstelling in 1973 bieek dac $\mathbb{1} 700$ auto "s elke schooldag leerlingen aanvoeren en weer weghalen in de Leivense binnenstad. 
Fonteinstraat-Ridderstraat, wil men op termijn de handen vrijkrijgen voor de realisatie van de renovatieplannen. Het is in dit verband opvallend dat vooral deze woningen opgekocht worden die in het tracé liggen van de geplande invalsweg die vanaf de Mechelsesteenweg het centrum (Koning Albertlaan) zal bereiken via $\mathrm{o}: \mathrm{m}$. de Donkerstraat en Brouwersstraat. Dit zou er op kunnen wijzen dat de probleembenadering niet zozeer globaalmatschappelijk is als wel technisch-urbanistisch. Bevestiging hiervoor kan $0: m$. gevonden worden in de geringe interventie van de stad bij de herhuisvesting van de betrokken bevolking. Aangezien er in de regel niet onteigend wordt, stellen er zich hier zeiden manifeste problemen. De betrokkenen zorgen zelf voor een "oplossing". Uiczondering op deze situatie vormen de 20 flats van een privé-bouwonderneming die door de stad via de grondregie werden verworven om ter beschikking gesteld te worden van de 'buurtbewoners":

Eenmaal een zone als gevolg.van hoger genoemde aankooppolitiek zo goed als onbewoond is geworden, kan men aan massale sloping denken en ruimte kreëren voor bouwprojekten. Dit stadium wordt thans bereikt in BPA Bruulhoek. Na de sloping van een 200-tal woningen zal hier aan appartementsbouw gedaan worden. Het is zeer de vraag of de huidige bewoners voor deze flats reeel in aanmerking zullen komen. Ook de doorverwijzing naar de Samenwerkende Maatschappij voor Huisvesting blijkt in de prakijk niet zo vlot te verlopen, zodat men zich kan afvragen of deze noodzakelijke saneringsprojekten de oorspronkelijke bewoners witeindelijk nit in de kou laten staan ten voordele van nieuwe en financieel-sterkere bevolkingskategorieën.

\section{3.2. Stadsuemieuiwng}

De overheidsinterventie wil zich echter niet beperken rot een saneringsinspanning. In een breder perspektief wil het stadsbestuur het stedelijk woon- en leefpatroon reorganiseren en aktiveren, en het naar de toekomst toe vrijwaren. Met dit doel voor ogen werd in samenwerking met de Interkommunale voor streekontwikkeling Interleuven een grondige survey opgemaakt van stad en stadsgewest. Het zijn inderdaad krachclijnen yoor de toekomst die men uit dit projekt ${ }^{9}$ Leuven $2000^{\prime}$ naar voor wil zien komen, meer bepaald ook indikaties voor de renovatie van de stadskern. Deze studie vormt dan ook de vertrekbasis voor een internationale urba- 
nustische wedstrijd met ais thema de valorısering van de binnenstad.

Reeds op dit ogenblik iliustreren een paar projekten deze blikverruiming. Achter de uicbreiding van onderwijsinrichtingen, administratieve diensten en industriële vestigingen werd principieel een punt gezet. De universiteic had reeds eerder de beslissing genomen de medische fakulteit te dekoncentreren naar de Gasthuisberg, ten dele buiten het stadsgebied. De uitbreidingsplannen van de Beigische Boerenbond werden afgewezen, terwijl de zone bestemd voor industrievestiging kon worden ingekrompen. Door het overbrengen van het bedrijf VEL aan de Pereboomstraat naar het industriecerrein te Haasrode, en als gevolg van de nieuwe mogelijkheden die Artols kreeg door het vrijkomen van industriegronden, kan een zone in BPA Vaartkom nu bestemd worden voor woningbouw.

In ditzelfde BPA is ook het "Kiein Begijnhof" gelegen. In het kader van een globale renovatie van de wijk zal dit wardevol historisch patrimonium op een verantwoorde wijze geïntegreerd motten worden in een woonomgeving die hoofdzakeijjk uit architektonisch-progressieve nieuwbouw zal bestaan. De restauratie van het Klein Begijnhof overstijgt dan ook duidelijk de eng-kulcurele sfeer. Het "masterplan" zal daarom mede gerealiseerd worden vanuit een Stichting waarin naast de stad (aandee $1: 10$ miljoen $F_{*}$ ) ook privê-deskundigen en het mecenat zitcing hebben. In tegenstelling tot het Groot-Begijnhof - dat we hier niet bespreken omdat her beheerd word d door de K.U.Leuven - zal er hier dus geen restauratie plaats vinden van een "stad in de stad", maar een renovatie van een totale wijk waarbij men trach het historisch waardevolle deel te valoriseren. In dezelfde geest werd ook voor de Vismarkt een masterplan opgemaakt, speciaal om het historische "Collegium Trilingue" beter tot zijn recht te lacen komen.

Ienslotte kunnen in het kader van de stadsvernieuwing ook de plannen aangehaald worderi om de verkeersstroom in de binnenstad te reorganiseren. Het betreft hier niet zozeer de verkeersontslulting via belangrijke infrastruktuurwerken ( 1 ), als wel het planmatig opvangen en spreiden van het gemotoriseerd- en voetgangersverkeer, zodat de city-funkties van de stadskern beter tot hun recht komen. Een eerste investering in dit

(i) Zie verder onder 3.2 : verkeersontsluiting. 
verband bedraagt $10 \mathrm{miljoen} \mathrm{F}_{\text {. }}$, voorzien voor 1974. Aan deze planning werd intensief meegewerkt door de betrokken middenstanders, want vanaf 1975 zullen de eerste verkeersvrije straten opengesteld worden : o.m. een deel van de Diestsestraat, later ook een deel van de Mechelsestraat. Het oplossen van de parkeerproblemen vormt bij dit alles natuurlijk een knelpunt. De stad wil grote ondergrondse parkings gaan bouwen ( $0 . m$. op de Oude Martk : 40 miljoen voorzien op de begroting 1974) maar ook de privé-parkeergebouwen stimuleren. Bij het toekennen van een bouw- of verbouwingsvergunning wordt het aanleggen van parkeerplaatsen verplicht gesteld. Een nieuw belastingsreglement voorziet een boete van $65.000 \mathrm{~F}$ per parkeerplaats ingeval van verzuim.

Stadsvernieuwing kan men bezwaarlijk een aparte beleidssfeer noemen met een nauwkeurig afgebakend uitgavenpatroon. Uit de bespreking van het geheel van matregelen die sinds enige tijd in een typische historische centrumstad als Leuven genomen worden, blijkt echter overduidelijk dat deze invalshoek een zwaartepunt is gaan vormen in het globale beleid. Gekombineerd met de inspanningen voor restauratie enerzijds en sanering anderzijds, is het groeiend belang van het "beleidsmoment" - stadsvernieuwing onloochenbaar. Tevens rijst natuurlijk de vraag op welk niveau de lasten gedragen moeten worden van een renovatie die de hele agglomeratie ten goede komt.

\subsection{HUISVESTINGSBELEID}

Reeds bij de bespreking van het grondbeleid werd het kreëren van woongelegenheden als een beleidsprioriteit bij uitstek naar voor geschoven. Voor een stad als Leuven die af te rekenen heeft met een selektieve oncvolking is een breed aanbod van gedifferentieerde woonruimte levensnoodzakelijk geworden. Het streefgetal van 40,000 inwoners is dan ook nog wat anders dan de groeiprognose van een expansieve gemeente. Het is veeleer een optimale verhouding tussen de woonfunktie van de stad en de funkties tewerksteliing en dienstverlening, afgestemd op het noodzakelijke inkomen voor de stad om de behoeften te kunnen dekken. Dit evenwichtspunc wordt vooralsnog binnengemeentelijk nagestreefd. Het is 
zeer de vraag of de optimale verhouding tussen woonzones, tertiaire sektor, industrie- en rekreatiegebieden in een breder perspektief niet anders zou liggen.

Hoe dan ook, in de Leuvense doeleindenstruktuur staat de 'leefbaarhaid' van de binnenstad centraal, en deze leefbaarheid houdt nier enkel verband met de ruimtelijke planning ( $A, P, A$, , B.P.A. "s), maar al evenzeer met de bouwinspanning die de bevolkingskurve in positieve zin moet beinvioeden. Het aantal bouwvergunningen voor nieuwbouw lag in 1973 op het eerste zicht vrij laag: 31. Het gaat hier echter steeds om woongebouwen, zodat het aantal nieuwe woongelegenheden op 500 geraamd kan worden.

De initiatieven die de stad zelf via de grondregie genomen heeft, zijn nog maar aan hun eerste faze toe. Op termijn zal deze inspanning zich ongetwijfeld intensiefiëren. In tegensteliting tot de projekten van de Samenwerkende Maatschappij voor de Huisvesting is het aanbod van de stad eerder gericht op de middenkategoriee̊n. Deze 'taakverdeling' is echter niet het resultat van enige planning of zelfs van afspraken, De S.M, voor de Huisvesting is ni. geen soepel instrument dat de stad kan hanteren bij het uitwerken van haar huisvestingsbeleid. Wel liggen grootscheepse projekten als dit van St. Maartensdal natuurlijk in de algemene iijn van het stadsbeleid.

Ook de C.0.0. denkt aan het kreëren van woongelegenheden, maar dan specifiek aan service-flats voor bejaarden en gehandikapten. Dit projekt in de F. Lintstrat wordt uitgewerkt in samenwerking met de S.M. voor de Huisvesting, maar ook hier is het stadsbestuur niet rechtstreeks bij de planning betrokken. Het ziet er dan ook naar uit dat de grote objektieven wel geformuleerd worden door de stedelijke beleidsorganen, maar dat hun inpakt op de konkrete verwerkelijking zeer partieei is. De verklaring voor deze juxtapositie van inzichten en inspanningen is wellicht te zoeken in historisch gegroeide situaties waraan de politieke bindingen niet vreemd zijn. Het stadsbestuur zal in de toekomst beter gewapend $z i j n$ om een eenheidsvisie door te drukken, ook $t \cdot a \circ v$, het pri- 
vê-initiatief, naarmate het algemeen plan en de bijzondere plannen uitgewerkt zullen zijn en bindende kracht zullen krijgen.

2. Socio-kultureel, milieu- en welzijnsbeleid

\subsection{MILIEUBELEID}

\subsubsection{Groenzones}

In een grotendeels dichtgebouwde stad als Leuven nieuwe groenzones aanleggen is een schier onmogelijke opgave. Een milieubewust beleid zal daarom eerder gericht zijn op het valoriseren van het beperkte openbare groen en het vrijwaren van het privë-groen. Er zijn inderdaad nog een aantal grotere tuinen voorhanden, vooral van kloostergemeenschappen, die bij het wegtrekken uit de binnenstad verloren zouden kunnen gaan. Het openbare groen van zijn kant beperkt zich in hoofdzaak tot het stadspark en de kruidtuin. Naast de aangebrachte verbeteringen a an beide groenvoorzieningen, zijn het vooral de aanleg en het onderhoud van de vele plantsoenen in de stad die het overgrote deel van het budget voor hun rekening nemen. De hoge personeelskosten slaan nl. op een plantsoendienst met 40 werknemers.

In het Noord-Westen van de stad is nog een belangrijke niet-bebouwde zone aanwezig. Deze is ten dele aangewend voor tuinbouw. De provinciale tuinbouwschool is hier ten andere gelegen. In de wijk Kareelveld die thans uitgebouwd wordt (zie huisvestingsbeleid) is er daarentegen een park-zone voorzien. Ook de groen-voorzieningen in het aansluitende Gasthuisberg-projekt krijgen aandacht. Hier heeft de stad voor $18 \mathrm{mil-}$ joen geinvesteerd in de groenzone, maar kan dit bedrag onmiddellijk rekupereren van de Universiteit $(6.300 .000 \mathrm{~F})$ en de staat $(11.700 .000 \mathrm{~F})$. De stad heeft in feite dus slechts een bemiddelende rol gespeeld. Deze 'investering' wordt dan ook niet verrekend in de overzichtstabellen. 


\subsubsection{Strija tegen de poilutie}

In een zeer algemene zin kan men de sub \& (grondbeleid) aangehaalde inspanningen om de industriezone duidelijk te omlijnen en zelfs effektief terug te dringen, beschouwen als een poging om de binnenstad zoveel mogelijk hinder te besparen.

Meer rechtstreeks is het stadsbeleid echter gericht op de zuivering van de afvalwaters. De verontreiniging van alle waterlopen is $\mathrm{nl}$, alarmerend vanuit het standpunt van de volksgezondheid en de milieuzorg. Onder de auspiciën van de intercommunale Interleuven werd hieromtrent sen studie uitgevoerd (stadsbijdrage i miljoen), die heeft geleid tot het oprichten van een incerkommunaal waterzuiveringsstation, waaraan Leuven participeert.

\subsection{SPORTBELEID}

Tijdens het mandaat 1953-58 werden twee belangrijke initiatieven genomen, waarvan de afwerking (en de afbetaling) deze beleidssfeer tot op heden gedomineerd heeft. Bedoeld worden het nieuwe zwembad aan het Hogeschoolplein (een investering van zowat 20 miljoen $F$. in illo tempore) en de oprichting van het sportcentrum aan de Naamse poort. In een eerste fase (aankoop van gronden en aanleg van de terreinen) was hier een investering van 8,6 Miljoen $\mathrm{F}$, mee gemoeid, maar sindsdien werden de terreinen uitgebreid, omgebouwd en beter uitgerust. Tijdens dit mandaat werd reeds 2,7 miljoen $F$, in het sportcentrum geïnvesteerd, terwijl voor een bedrag van 6,5 miljoen aan nog op te nemen leningen is voorzien. Anderzijds kan men met de opbrengst van de verkoop van de stadsscholen aan het Rijk en een deel van de Mechelsevest aan de Intercommunale E5, een kunststofbaan in het sportcentrum rechtstreeks financiëren ( 15 miljoen F.). Inzake het uitbouwen van wijkvoorzieningen voor sport en spel, dateert het laatste initiatief van 1956, toen het "kwartjerspeelplein De Bruul" aangelegd werd (stadsaandeel 3,3 miljoen $F$ ). Dit speelplein is belangrijk omwille van zijn omvang en uitrusting, maar vooral door zijn ligging in het hart van een te saneren wijk. In 1972 werden verbeteringswerken uitgevoerd. Op de begroting 1974 is I miljoen uitgetrokken voor het aanleggen van nieuwe wijkspeelpleinen. Niet onmiddelijjk een prioritaire optie dus in een binnenstad waar nochtans een dringende nood aan zulke 
voorzieningen bestaat. Het aanbod van geschikte terreinen is natuurlijk wel zeer beperkt,

De meest markante realisatie van het huidig stadsbestuur in deze beleidssfeer, moet, naast de verdere uitbouw van het sportcentrum, gezocht worden in de ombouw van de voormalige Rijschool tot een polyvalente sporten feestzaal. Deze verbouwingswerken hebben de stad 5,6 miljoen F. gekost, maar de sportbeoefenaars kunnen nu in het stadscentrum verschillende zaalsporten beoefenen. Naar de toekomst toe wordt gedacht aan een grote sporthal. Ook het terrein dat in de Tiensestraat verworven werd (zie grondbeleid) kan wellicht voor sportinfrastruktuur aangewend worden. Een sportraad werd opgericht om de dialoog te verzekeren tussen sportbeoefenaars en overheidsinitiatief. Speciaal de popularizering van de sportbeofening staat centraal in dit beleid, maar het is zeer de vraag of dit niet te exklusief nagestreefd wordt via de uitbouw van de infrastruktuur voor de 'grote' sport en ten nadele van de aktieve en passieve openluchtrekreatie in de binnenstad. Zoals reeds gezegd, is dit latste streefdoel echter bijzonder moeilijk te realiseren in het kader van een kompakte bebouwing als deze van een oude stad.

\subsection{KULTUURBELEID}

Dit begrip kan in brede en in enge zin geïnterpreteerd worden. In de ruimste betekenis van het woord vallen hieronder zowel de initiatieven om de infrastruktuur voor socio-kulturele aktiviteiten te valoriseren en uit te breiden, als de impulsen die het stadsbestuur wil geven aan het kulturele leven zelf. Ook de restauratie van historisch-waardevolle gebouwen kan hiertoe gerekend worden. De stadskernvernieuwing als globaal probleem bespraken we echter reeds sub 1.3.2. Opvallend voor deze beleidssfeer is de spreiding van de uitgaven over verschillende begrotingsposten. Het is dan ook niet zo eenvoudig een koherent en sluitend beeld op te hangen van het kultureel beleid. Enkele krachtlijnen tekenen zich evenwel af. Leuven wordt gekonfronteerd met een dringende behoefte aan ruimte voor specifiek-hedendaagse socio-kulturele aktiviteiten. De stadsschouwburg en het stadsmuseum zijn niet gekoncipieerd voor het beleggen van massale vergaderingen, feesten of tentoonstellingen, en al evenmin voor het werken met kleinere groepen. In beide richtingen 
werden door het huidige stadsbestuur belangrijke initiatieven genomen. De voormalige Rijschool werd omgebouwd tot een polyvalente sportzaal (1), die tevens geschikt is voor het inrichten van massa-samenkomsten en handelsbeurzen. Toch blijft er een vraag bestaan naar een ad-hoc ruimte voor kommerciële manifestaties. Uit de mogelijke alternatieven werd uiteindelijk geopteerd voor een polyvalent komplex dat mede door privé-kapitaal opgericht zal worden op de terreinen van het huidig stedelijk slachthuis. Dit slachthuis beëindigde nl, zijn aktiviteiten per 31 december 1974 (2). In het op te richten komplex is ook kongresruimte voorzien. Onder de funktie hande1 en nijverheid wordt daarom een nog op te nemen lening van 2 miljoen $F$. ingeschreven als stadsaandeel voor het bouwen van een auditorium.

Ook naar een geschikte infrastruktuur voor meer groeps- en verenigingsgerichte socio-kulturele aktiviteiten werd uitgekeken. Het historisch pand dat voorheen bewoond werd door de Gasthuiszusters - Augustinessen (Brusselsestraat) werd verworven met het oog op de uitbouw van een kultureel centrum. Deze optie werd echter (voorlopig?) verworpen door de voogdij-overheid, zodat enkel de dringend-noodzakelijke restauratie- en instandhoudingswerkzaamheden uitgevoerd kunnen worden.

De restauratie van het historisch patrimonium betekent een zware opgave voor de stad. Leuven valoriseren als 'openluchtmuseum voor architektuur' veronderstelt inderdaad een permanente zorg voor tal van gebouwen, en vooral dan kerken. Deze zorg wordt gedeeld door het Rijk (Kommissie voor monumenten en landschappen) en door de kerkfabrieken, zodat het onderling samenspel geen eenvoudige opgave is. Ook de financiële last is zeer verdeeld en verschilt van situatie tot situatie, o.m. omwille van eventuele oorlogsschade.

Bijna alle kerken waren betrokken bij instandhoudingswerken, maar grondige restauratiewerken vonden plaats aan de St. Pieterskerk, de St. Kwintenskerk en de $S t$. Jacobskerk. Verder werden de oude Kartuizerij en het St. Niklaashuis gerestaureerd. Het stadhuis zelf kreeg een grondige opknapbeurt, waarbij ook ontbrekend beeldhouwwerk aangevuld wordt.

(1) Zie onder sportbeleid : 2.2 .

(2) Zie verder onder sociaal-ekonomisch beleid : 3.1 . 
Al deze initiatieven moeten in het kader gezien worden van een globale renovatie van de binnenstad, een beleidsprioriteit bij uitstek van het huidig bestuur. Het spreekt echter vanzelf dat deze inspanning - hoezeer ook gesteund door het Rijk en privé-instanties - een onredelijke belasting betekenen van de stadsbegroting.

Dit geldt al evenzeer voor de meer traditionele kulturele voorzieningen, warvan de aktieradius zich duidelijk uitstrekt tot het hele stadsgewest. De stadsschouwburg springt bierbij in het oog, maar het is vooral in het kultureel komplex aan de Vanderkelenstraat/Savoyestraat dat de jongste jaren geïnvesteerd werd. Het museum werd uitgebreid, de leeszaal van de bibliotheek grondig vernieuwd en vooral werd er een stedelijke diskotheek opgericht. De stadsbibliotheek kreeg twee nieuwe filialen, $\mathrm{n} 1$. in de Brabançonnestraat en in St. Maartensdal. Vooralsnog betekenen deze uitbreidingen een verzwaring van de personeelslast, maar het stadsbestuur verwacht een spoedige overname van dit personeel door het Rijk (dekreet in voorbereiding).

Al komt het onderwijs - en dus ook het kunstonderwijs - in deze studie niet rechtstreeks ter sprake, toch dient er hier volledigheidshalve gewezen te worden op het samenspel tussen de genoemde kulturele voorzieningen en de stedelijke akademie voor schone kunsten enerzijds, het conservatorium anderzijds. De akademie makt trouwens integrerend deel uit van het komplex aan de Vanderkelenstraat. Het stedelijk conservatorium van zijn kant werd afgebroken en zal eerlang herbouwd worden. Aan de voorbereiding hiervan besteedde de stad reeds 2,5 miljoen F., voor de realisatie werd 20 miljoen F. ingeschreven. Een optie van dit format mag niet onvermeld blijven. Samen met de andere, meer bescheiden inspanningen, vormt ze een illustratie van de vernieuwde aandacht voor de aktieve kunstbeoefening en het kulturele leven in het algemeen. Het verenigingsleven krijgt inspraak bij de vormgeving van het kultuurbeleid via de in 1973 opgerichte kultuurraad. Dit adviesorgaan fungeert tevens als overlegstruktuur tussen de verenigingen voor amateuristische kunstbeoefening, vormingswerk en vrijetijdsbesteding, zodat niet alleen $t . a . v$. de overheid maar ook naar de interne werking een zekere bundeling van de inzichten en inspanningen mogelijk wordt. Dit overleg heeft ten andere reeds aanleiding gegeven tot het opzetten van gemeenschappelijke aktiviteiten. 


\subsection{JEUGDBELEID}

Belangrijke investeringen zijn in deze beleidssfeer niet te noteren, althans niet inzake specifieke jeugdvoorzieningen. Over de aanleg van sport- en speelpleinen in de wijken werd reeds sub 2.2. (sportbeleid) gehandeld. Wel kan men de oprichting van een stedelijke jeugdraad noteren met 52 aangesloten verenigingen. Dit overleg heeft aanleiding gegeven tot gemeenschappelijke aktiviteiten als de organisatie van een veertiendaagse van de gehandikapten en de promotie van het kultureel jongerenpas poort.

Wat het opvangen van jongeren tijdens de zomervakantie betreft, werden in onderling overleg initiatieven genomen om op bepaalde plaatsen in de stad monitoren ter beschikking te stellen voor de spelbegeleiding van de kinderen van de wijk. Een vrije formule dus, naast de reeds lang gesteunde vakantiespeelpleinen die door het privé-initiatief buiten de stad georganiseerd worden.

Een duidelijk profiel van het stedelijk jeugdbeleid is dan ook moeilijk te tekenen. De stad brengt de jongerenorganisaties samen, steunt hun werking en de gemeenschappelijke initiatieven, maar intervenieert niet rechtstreeks. Dit blijkt ten andere overduidelijk uit de uitgaventabel (gewone dienst en investeringen).

\subsection{WELZIJNSZORG}

In tegenstelling tot de trend die in sommige gemeenten waar te nemen is, wordt de welzijnszorg in de breedste betekenis van het woord gerekend tot de taaksfeer van de C.0.0. De leuvense kommissie wil enigszins anticiperend op de vermoedelijke oriëntering van de C.0.0.'s reeds nu een centrum zijn voor maatschappelijk welzijn. Naast de klassieke taken als het ziekenhuiswezen (Akademisch Ziekenhuis St. Pieter) en de bejaardenzorg (Instituut E. Remy), beheert de C.0.0. ook een psychiatrisch instituut voor vrouwen en twee jeugdtehuizen. Via de sociale dienst van de C.0.0. wordt een globale probleembenadering en -oplossing nagestreefd voor individuele moeilijkheden, terwijl de dienst Gezins- en bejaardenhulp hulp en verzorging ten huize organiseert. Het bouwen van 
service-flats voor bejaarden ligt ter studie (1).

Op deze aspekten van het welzijnsbeleid gaan we in deze studie niet nader in, omdat ze ontsnappen aan de rechtstreekse invloed van de gemeentelijke beleidsformulering. Deze vaststelling alleen lijkt ons reeds relevant. Stadsbestuur en C.0.0. gaan elk hun eigen weg. De nauwkeurige afbakening van takenpakketten verhindert ernstige bevoegdheidsbetwistingen, maar sluit ook een globale beleidsvisie uit. Het welzijnsbeleid kan moeilijk gebaat zijn bij deze situatie. Bevestiging voor deze stelling kan o.m. gevonden worden in de moeilijke positie van inspraakorganen als de gezinsraad en vooral de bejaardenraad. $\mathrm{Zij}$ worden geacht het stadsbestuur te adviseren $\mathrm{i} . \mathrm{v} . \mathrm{m}$. materies die geheel of ten dele door de C.0.O. behartigd worden : gezinshulp, bejaardenzorg, maatschappelijke dienstverlening. In het beleidsvormingsschema is deze extensieve taakperceptie van de C.0.0. een eenheidsverstorende faktor. Volledigheidshalve dient hieraan toegevoegd dat de inspraakorganen ook een belangrijke betekenis hebben als interne overlegstruktuur en ze gemeenschappelijk bepaalde aktiviteiten op touw kunnen zetten. Uitzondering op de regel die de welzijnszorg goeddeels onttrekt aan het stadsbestuur, vormen de kinderdagverblijven en peutertuinen.

3. Sociaal-ekonomisch en infrastruktuurbeleid

\subsection{STADSBEDRIJVEN}

Het is eigen aan een regionaal centrum diensten te presteren waarvan de draagwijdte de stadsgrenzen ruim overschrijdt. Als erfenis uit het oostenrijks tijdvak heeft Leuven aldus het kanaal naar de Rupel - via Mechelen - moeten onderhouden, tot het onlangs door het Rijk werd overgenomen. Niet alle regionale funkties zijn even bizar, maar soms wel even zwaar om dragen. Het huidig stadsbestuur heeft echter de vèr-dragende optie genomen bepaalde diensten af te stoten waarvan de last te zwaar

(1) Zie huisvestingsbeleid : 1.4 . 
werd en of de taak te zeer de stedelijke aktieradius overschreed. Zo werden in de beleidssfeer onderwijs alle stadsscholen voor lager onderwijs (inclusief B.L.O.) en het hele stedelijk technisch onderwijs overgedragen aan het Rijk. Ook t.a.v. de stadsbedrijven zet deze optie zich door.

Einde 1973 besliste de gemeenteraad het stedelijk slachthuis te sluiten per 31 december 1974. Sinds 1965 waren er nochtans voor méér dan 10 miljoen F. verbeteringswerken uitgevoerd, waarvan 6 miljoen op stadskosten. Toch kon men de E.E.G.-exportstempel niet behouden en was het slachthuis veroordeeld tot een sterk gereduceerde aktiviteit. Zware investeringen drongen zich op om weer exportslachthuis te worden. De interkommunale Interleuven werd gepolst naar de mogelijkheid een nieuw slachthuis op te richten volgens een formule van interkommunale samenwerking. Het antwoord was negatief. Ondanks het feit dat het slachthuis niet zo katastrofaalverlieslatend is (een mali van 1,5 miljoen $F$. is voorzien in de begroting 1974), besloot men toch het stadsbedrijf te sluiten. Het feit dat slechts 1/4 van de betrokken grossiers en 1/5 van de betrokken beenhouwers uit de stad afkomstig zijn, heeft deze zware beslissing wel vergemakkelijkt.

Deze optie heeft naar ons aanvoelen een meer dan anekdotisch karakter en overstijgt het strikt lokale kader. Voor de stad is niet zozeer het huidig deficit doorslaggevend geweest als wel de vaststelling dat een bepaalde kwaliteits-dienst (in casu : een exportslachthuis) niet langer tot de mogelijkheden behoorde. Liever dan gewoon verder te werken volgens het verouderde patroon, heeft het stadsbestuur de knoop doorgehakt. Het vacuum dat aldus ontstaat is hier niet onoverbrugbaar. Maar als trend inzake de behartiging van openbare diensten is de Leuvense beslissing toch een teken aan de wand. De supra-lokale taak wordt hier immers niet uitgespreid over de regio via interkommunalisatie. Ingeval van een akuut vacuum zal het de hogere overheid (provincie, Rijk) zijn die zal inspringen, en aldus de taakverglijding in de hand werken. 


\subsection{VERKEERSONTSLUITING}

De ontsluiting van de Leuvense agglomeratie is door het opstellen van de E5 en het ontwerpen van de A2 nog niet afgerond. Tussen beide autowegen zijn dwarsverbindingen voorzien, maar de tracés liggen begin 1974 nog niet overal definitief vast. Dit probleem overstijgt ten andere het gemeentelijk kader. Belangrijker is in ons perspektief in verkeersontsluiting binnen de agglomeratie, met name door het kreëren van nieuwe ring- en invalswegen.

Vanuit de richting Kessel-Lo werd een verbinding gerealiseerd tussen de Diestsesteenweg en de Diestsevest. Deze Vuurkruisenlaan maakt nu reeds een betere verkeersregeling mogelijk aan het Martelarenplein (station), maar zal in de toekomst via een overbrugging van de vaart ook toegang verlenen tot de ring rond Leuven. Het doortrekken van deze ring in de richting van de Brusselsepoort zal zware investeringen vergen. De nieuwe Vaartvest en Mechelsevest zullen n1. 4 rijstroken omvatten en op ongelijk niveau het verlengde van de Wijnpersstraat en de nieuwe invalsweg uit Mechelen kruisen. - Via de Wijnjpersstraat moet immers het verkeer uit het te urbaniseren Kareelveld een vlotte toegang krijgen tot de stad, terwijl de nieuwe invalsweg het verkeer vanaf de Mechelsesteenweg naar het centrum zal leiden via de Donkerstraat, Brouwerstraat en Albertlaan.

De verbinding tussen de stad en het medisch komplex van de Gasthuisberg wordt gerealiseerd door de verbetering en verlening van de Mannenstraat, die in een tunnel onder de Remyvest zal lopen.

De noordergedeelten van de stad, inklusief de industriezone aan de Vaart, maar ook de gemeenten Herent en Wilsele zullen vlotter toegang krijgen tot de E5 via een 'westelijke omleiding' die o.m. door het Kareelveld za1 lopen.

Tenslotte blijft het probleem van een additionele toegang tot de stad vanuit Kesse1-Lo en het oostelijk hinterland. In Kesse1-Lo wordt hiervoor een tracé vrijgehouden, maar in Leuven staat deze aansluiting niet prioritair.

Indien nog nodig, beklemtoont deze vaststelling de noodzaak de verkeersontsluiting in een breder perspektief te stellen. Ook de interferentie van de rijksplanning met de gemeentelijke planning maken een systematisch overleg onontkoombaar. 
4. Interne bestuursorganisatie

\subsection{PERSONEELSKADER}

Het effektieve personeelskader ziet er medio 1974 uit als volgt :

\begin{tabular}{|c|c|c|}
\hline & Pers & eden in \\
\hline & Ful1 & $\begin{array}{l}\text { Part-time } \\
\text { verband }\end{array}$ \\
\hline Algemene administratie & 79 & - \\
\hline Politie & 90 & - \\
\hline Brandweer & 53 & - \\
\hline Reinigingsdienst & 52 & - \\
\hline Technische dienst & 58 & $\begin{array}{l}\text { - waarvan } 13 \text { tot het technisch } \\
\text { personeel horen, } 45 \text { tot het } \\
\text { werkliedenpersoneel }\end{array}$ \\
\hline Drukkerij & 4 & - \\
\hline $\begin{array}{l}\text { Begrafenisdienst- } \\
\text { Begraafplaatsen }\end{array}$ & 9 & 4 \\
\hline Gezondheidsdienst & - & 2 \\
\hline Slachthuis & 7 & 3 \\
\hline Beplantingen & 35 & - \\
\hline Sport & 27 & - \\
\hline Museum & 7 & - \\
\hline Schouwburg & 9 & 4 \\
\hline Conservatorium-Akademie & 3 & - \\
\hline Bibliotheek & 16 & 12 \\
\hline & $\overline{449}$ & $\overline{25}$ \\
\hline
\end{tabular}

In dit totaalcijfer van 474 personeelsleden zijn de leraars aan het conservatorium en de akademie niet inbegrepen. Het overige onderwijzend personeel is n.a.v. de overdracht van de stadsscholen mee naar het Rijk overgegaan.

Indien men uit het kader het personeel in reliëf zou willen brengen dat rechtstreeks instaat voor taken uit de socio-kulturele sfeer (cfr. overzichtstabellen bij de bespreking van deze beleidssfeer), krijgt men volgend beeld : 
Milieubeleid : groenzones, beplantingen = 35 personeelsleden Sportbeleid : sportcentrum, sporthal $=27$ personeelsleden Kultuurbeleid = museum, schouwburg, conservatorium, akademie, bibliotheek

In de sfeer van het jeugdbeleid en de sociale dienstverlening (cfr. 2.4. en 2.5.) zijn geen personeelsleden aan te wijzen die deze taken hoofdambtelijk behartigen.

\subsection{KOLLEGE VERSUS ADMINISTRATIE}

Het heeft weinig zin in dit verband de hiërarchische struktuur in het personeelskader te bespreken. Deze geleding beantwoordt aan de normen die door de voogdij-overheid aangehouden worden. Belangrijker is echter de vaststelling dat de top van deze pyramidale opbouw erg zwak uitvalt. Het eigenlijke kaderpersoneel dat in dialoog met het kollege de dagelijkse leiding van de beleidsvoorbereiding en -uitvoering zou moeten waarnemen, is - behoudens uitzonderingen - niet op die taak berekend. In de sektor van de algemene administratie bv. klimt men exklusief via het kader op tot de hoogste funkties. Aan de top krijgt men aldus mensen die niet beantwoorden aan de (bij)scholingsverwachtingen die men t.a.v. het kaderpersoneel van een stad met regionale betekenis als Leuven zou mogen ste11en.

Dit ligt wel anders in de sektor van de meer technische diensten. Daar wordt de ingenieur-direkteur der werken bijgestaan door een architekturbanist, een kondukteur der werken en twee technisch ingenieurs. Op de politiekommissaris, de direkteur van het slachthuis en de part-time geneesheren van de gezondheidsdienst na, zijn deze kaderleden echter de enige afgestudeerden uit het hoger onderwijs. Zelfs voor de thans vakante betrekking van stadssekretaris wordt geen universitair diploma vereist. Zonder de relevantie van de diploma's voor de kwaliteit van de ambtenaren te willen overdrijven, is deze vaststelling toch symptomatisch voor een bepalde houding en mentaliteit. De beleidsverantwoordelijken hebben in het verleden het administratieve topkader slechts zeer partieel betrokken bij de eigenlijke besluitvorming. Administratie 
was synoniem van uitvoerend werk. Nu een aantal schepenen in het kader van een systematisch en planmatig beleid behoefte hebben aan administratieve ruggesteun, blijkt het kader niet opgewassen te zijn voor die taak. Het ziet er niet naar uit dat deze hypotheek uit een periode van traditioneel bestuur de eerstkomende tijd gelicht zal worden, ook al omdat niet alle beleidsverantwoordelijken de nood even scherp aanvoelen. Zolang ze op het delikate technische vlak (urbanisatie, openbare werken) inderdaad op kompetente staffunktionarissen kunnen rekenen, worden de deskundigheidseisen t.a.v. het overige personeel niet te hoog gesteld. Voor de toekomstige behartiging van taken in de steeds bredere sociokulturele sfeer stelt dit ernstige vragen.

5. Bespreking van het uitgavenpatroon

\subsection{ALGEMENE SITUATIE}

Als typisch regionaal centrum hoeft het geen betoog dat Leuven een aantal taken opgedragen kreeg of effektief vervult die de stadsgrenzen ruim overschrijden en de uitgavenlast versterken. Desondanks komt de globale financiële situatie van de stad niet zo negatief voor als de alarmkreten in het kader van de groep der regionale steden doen vermoeden (1). De begroting van 1974 sluit met een mali van 28.919 .557 F. op een globaal bedrag van nagenoeg 400 miljoen, n1. 399.207.149 F. Niet alleen betekent dit slechts een verhoging van het deficit met $0,45 \%$ sinds het vorig jaar, tegenover een stijging van de uitgaven met $8,77 \%$. Bovendien dient rekening gehouden te worden met de extra steun vanwege het Ministerie van Binnenlandse Zaken (hulpfonds en speciale hulpgelden) voor een bedrag van meer dan 21 miljoen $F$.

In kombinatie met een aantal budgettaire operaties kan er aldus nagenoeg een evenwicht bereikt worden voor het dienstjaar 1974. De 1ast van het

(1) Zie de studie 'Regionale steden en steden in expansie', onder de auspiciën van het Instituut Administratie-Universiteit, 1973. 
verleden blijft echter drukken : samen met het huidige dienstjaar bedraagt het nadelig saldo bijna 80 miljoen F. (79.347.124 F.) (1). De ruimte die overblijft voor innoverende beleidsopties is dan ook noodgedwongen beperkt. Toch heeft het huidig stadsbestuur een aantal beslissingen genomen met verregaande draagwijdte, ook op het financiële vlak. Door het afstoten van onderwijsinrichtingen en de verkoop van stadspatrimonium konden belangrijke schulden gedelgd en opties genomen worden. Het overdragen van het stedelijk technisch instituut an het Rijk en de verkoop van de stadsmagazijnen (intussen elders herbouwd) aan de Gewestelijke Samenwerkende Maatschappij voor de Huisvesting lieten de stad toe een zeer bezwarende kredietopening van 30 miljoen F. bij de Generale Bankmatschappij integraal terug te betalen. Het overdragen van de stadsscholen (lager onderwijs) aan het Rijk en de gedeeltelijke opbrengst van een verkoop van gronden aan de Mechelsevest aan de Interkommunale E5 (ring rond Leuven) konden de aanleg van een kunststofbaan in het sportcentrum financieren ( $15 \mathrm{miljoen}$ F.), samen met de bouw van een ondergrondse parking aan de Oude Markt (40 miljoen F.). Beide projekten werden respektievelijk onder sportbeleid (2.2) en staskernvernieuwing (1.3.2.) besproken. Hier dienen we vooral de aandacht te trekken op de ongewone procedure. Voor deze belangrijke infrastruktuurwerken ging men geen lening aan, maar werd het stadspatrimonium aangesproken. Deze beslissing kan dan ook gezien worden in het licht van een bredere optie, n1. het afstoten van opdrachten en diensten die voor de stad zelf 'irrelevant' zijn geworden, nl. te zwaar in funktie van hun beperkt belang (cfr. ook slachthuis, vaart). Men kan zich natuurlijk afvragen of dit in hoofdzaak financieel criterium voor het bepalen van de relevantie van bepaalde stadstaken wel gerechtvaardigd is. Dient het uitgangspunt niet veeleer de zin zelf te zijn van een bepaalde taakverdeling tussen de bestuurslagen, terwijl de konkrete haalbaarheid voor de verschillende niveaus door aangepaste maatregelen gewaarborgd moeten worden. Door het ontbreken van deze taakverdeling stoten lokale besturen taken af (bv. de onderwijstaak), zonder dat hierbij de konsekwenties inzake de uitholling van het lokale niveau voldoende onderkend worden.

(1) Gegevens ontleend aan het 'Verslag aan de gemeenteraad dd. 28.3.1974, waarin Schepen van Financiën J. Vandeputte de begroting voor 1974 voorste1t. 


\subsection{BESPREKING PER FUNKTIE (1)}

Het reliëf in het uitgavenpatroon komt wellicht het duidelijkst naar voor, indien we uit het begrotingsoverzicht - gewone dienst - voor het jaar 1974 deze funkties lichten die minstens $5 \%$ van het globale uitgavenpakket vertegenwoordigen :

\begin{tabular}{l|r|r|r|r}
\hline Funkties & $\begin{array}{c}\text { Uitgaven } \\
\text { per inw. }\end{array}$ & $\begin{array}{c}\text { In \% van } \\
\text { het tot. }\end{array}$ & $\begin{array}{c}\text { Netto-uit- } \\
\text { gaven per } \\
\text { inwoner }\end{array}$ & $\begin{array}{l}\text { In \% van } \\
\text { het totaa1 }\end{array}$ \\
\hline Algemene administratie & 1.773 & 13,71 & 1.729 & 18,10 \\
Justitie-Politie & 1.648 & 12,73 & 1.607 & 16,81 \\
Brandweer & 885 & 6,84 & 627 & 6,57 \\
Verkeer-Wegen-Waterlopen & 2.315 & 17,88 & 1.633 & 17,09 \\
Volksontwikkeling en Kunst & 2.029 & 15,67 & 1.638 & 17,14 \\
Sociale voorzorg en onderstand & 703 & 5,43 & 703 & 7,36 \\
Ontsmetting-Reiniging-Huisvui1 & 975 & 7,54 & 895 & 9,37 \\
\hline
\end{tabular}

Wanneer we eerder de evolutie in de besteding per funktie analyseren, bekomen we een meer genuanceerd beeld. Dit overzicht is gebaseerd op de aangezuiverde (netto) uitgaven per inwoner zoals die blijken uit de rekeningen voor 1971 en 1972, en de begrotingen voor 1973 en 1974.

De snelle doch niet steeds gelijklopende ontwikkeling van de kosten, en de muntontwaarding in het algemeen, maken een vergelijking in de tijd weinig relevant indien men zich op absolute cijfers moet baseren. Daarom werd de evolutie nagegaan van het aandeel van de verschillende funkties in het globale uitgavenpakket.

Volgende funkties kunnen signifikant genoemd worden :

- 'Algemeen' en 'algemene schuld' gaan relatief licht achteruit.

- 'Algemene administratie' stijgt echter van 16,39\% (rekening 1971) tot $18,10 \%$ (begroting 1974).

- 'Privaat patrimonium' vertoont een stijging met $1 \%$, van 0,69 tot 1,69\%.

(1) Zie overzichtstabellen, in bijlage 3B. 
- Een soortgelijke verhoging voor 'algemene diensten', van 1,30 tot 2,52\%.

- 'Justitie-politie' blijft daarentegen nagenoeg stabiel.

- 'Brandweer' stijgt markant, van 4,99 tot 6,57\%.

- 'Verkeer - Wegen - Waterlopen' gaat integendeel relatief achteruit, van 19,13 tot $17,09 \%$.

- 'Handel en nijverheid' sluit de facto met een boni.

- 'Onderwijs' is te veronachtzamen, behalve dan het kunstonderwijs dat van 1,24 tot $1,98 \%$ stijgt, met een spits in $1973(2,79 \%)$. Deze top is echter irreëel en is te wijten aan de niet gerealiseerde uitgave van 20 miljoen voor het nieuw conservatorium.

- 'Volksontwikkeling en kunst' maakt een spektakulaire sprong, van 13,32 tot $17,14 \%$.

- 'Sociale voorzorg en onderstand' daarentegen, in feite het bijpassen van het deficit van de C.0.0., gaat relatief achteruit : van 11,78 tot 7,36 , ook al is de evolutie in de absolute cijfers niet zo sensationeel.

- 'Sociale hulp' en 'gezondheidszorg' zijn in dit overzicht te verwarlozen.

- 'Hygiëne, voeding en water' gaat iets stijgen, omwille van het deficit van het slachthuis en de voorbereidende studies voor het interkommunal waterzuiveringstation.

- 'Huisvesting en stedebouw' tenslotte blijft als funktie nog erg klein, maar stijgt toch van 0,39 tot $1,72 \%$.

Een meer verfijnde benadering van de uitgaven per funktie veronderstelt een zicht op het respektievelijk aandeel van personeelsleden, werkingskosten, overdrachten en schuld. Uit de overzichtstabel lichten we de meest markante gegevens (1). De tabel dient vertikaal gelezen te worden.

(1) Zie bijlage 3 B. 


\begin{tabular}{|c|c|c|c|c|}
\hline Funktie & $\begin{array}{l}\text { Personee1s- } \\
\text { uitgaven }\end{array}$ & $\begin{array}{l}\text { Werkings- } \\
\text { kosten }\end{array}$ & $\begin{array}{l}\text { Over- } \\
\text { drachten }\end{array}$ & Schuld \\
\hline Algemeen & & & \multirow{12}{*}{$\begin{array}{r}4,63 \\
90,51\end{array}$} & 6,83 \\
\hline Algemene schuld & & & & 5,16 \\
\hline Algemene administratie & 19,25 & 13,57 & & \\
\hline Justitie - Politie & 20,09 & & & \\
\hline Brandweer & 10,02 & & & \\
\hline Verkeer-Wegen-Waterlopen & 11,09 & & & 45,65 \\
\hline Kunstonderwijs & 5,46 & & & \\
\hline Volksontwikkeling en Kunst & 15,85 & 34,42 & & 8,33 \\
\hline Sociale voorzorg en onderstand & \multirow{4}{*}{8,74} & \multirow{4}{*}{15,74} & & \\
\hline Ontsmetting, reiniging, huisvuid & & & & \\
\hline Huisvesting en stedebouw & & & & 11,14 \\
\hline -. & & & & \\
\hline
\end{tabular}

\subsection{ALGEMENE BESPREKING}

Uit een eerste analyse van de uitgaven in de gewone dienst tekent zich reeds het profiel af van de beleidsprioriteiten voor het huidig stadsbestuur. In kombinatie met de investeringsuitgaven die in de loop van de bespreking der beleidssferen aangehaald werden, worden een aantal verschuivingen in de opties duidelijker. Helemal parallel met de politieke belangrijkheid van de opties loopt een niet-gedetailleerde financiële analyse echter nooit, omdat het beeld hier overtrokken wordt door zware uitgavenposten die weinig beleids-gevoelig zijn en veeleer tot de verplichte - of routine-uitgaven gerekend kunnen worden. Denken we aan 'algemene administratie', 'justitie-politie', en 'verkeer-wegen-waterlopen'. Toch dient deze algemene uitspraak gerelativeerd te worden. Indien 'justitie-politie' inderdaad nagenoeg stationnair blijft, dan kan dit niet gezegd worden van de 'algemene administratie', die budgetair aanzwelt, terwijl 'verkeer-wegen-waterlopen' relatief afneemt. Dit is des te merkwaardiger omdat in deze laatste beleidssfeer innovaties aan de orde zijn, zoals stadsrenovatie, terwijl de algemene administratie een vrij traditioneel beeld blijft vertonen, maar met snel stijgende personeelskosten af te rekenen heeft. 
Achter de term 'Volksontwikkeling en kunst' gaan een aantal beleidssektoren schuil die in sub 2 op een funktionele wijze werden ingedeeld en meer diepgaand besproken. Globaal beschouwd is het groeiend belang van deze funktie opvallend. Dit geldt allereerst voor het aandeel dat 'Volksontwikkeling' opeist in het geheel van de werkingskosten, maar slaat ook op belangrijke personeelsuitgaven. Hierbij denke men vooral aan de uitgebreide plantsoendienst.

T.a.v. de overdrachten ontstaat er bij een schematische voorstelling nagenoeg een monopolie voor de funktie 'sociale voorzorg en onderstand', dit als gevolg van het bijpassen van het deficit van de c.0.0. Een meer genuanceerd beeld van de overdrachten in de socio-kulturele beleidssfeer werd bij de bespreking ad hoc gegeven. De schuld tenslotte ligt evenwichtiger gespreid. Beleidsrelevant is hier vooral het toegenomen aandeel van de funktie 'stedebouw en huisvesting', een markante beleidsprioriteit voor het huidig kollege.

De aparte bespreking van personeelsuitgaven, werkingskosten, overdrachten en schuld mag nochtans de reële onderlinge verhouding niet uit het oog doen verliezen.

IN \% VAN DE GLOBALE UITGAVEN

\begin{tabular}{l|l|l|l|l|l|l}
\hline & $\begin{array}{l}\text { Personeels- } \\
\text { kosten }\end{array}$ & $\begin{array}{l}\text { Werkings- } \\
\text { kosten }\end{array}$ & $\begin{array}{l}\text { Over- } \\
\text { drachten }\end{array}$ & Schuld & $\begin{array}{l}\text { Interne } \\
\text { verrich- } \\
\text { tingen }\end{array}$ & Totaal \\
\hline Begroting 1973 & 58,79 & 10,83 & 5,97 & 23,49 & 0,92 & 100 \\
Begroting 1974 & 59,26 & 11,71 & 6,00 & 22,19 & 0,84 & 100 \\
\hline
\end{tabular}

De personeelsuitgaven eisen met nagenoeg $60 \%$ het leeuwenaandeel op, gevolgd door 'schuld' en werkingskosten. 


\section{Elementen van synthese (1)}

Wanneer men uit het geheel van de besproken beleidsopties de krachtlijnen in reliëf zou willen brengen, dan kan dit rond een drietal kern-doe1stellingen.

Er is allereerst de leefbaarheid van Leuven in de zin van een noodzakelijke aangroei van de bevolking om de zware dienstverlenende taken van de centrum-stad te kunnen spreiden over en te laten dragen door een vo1doende aantal inwoners. De selektieve ontvolking, met name van de inwoners uit de midden- en hogere inkomenskategorieën, moet tegengegaan worden door aantrekkelijke woonaanbiedingen in de binnenstad en in de periferie (Kareelve1d). Enkel bij een optrekken met 9.000 eenheden tot een bevolkingsoptimum van 40.000 , is een billijke spreiding van de lasten gewaarborgd en kan de city opnieuw een woonfunktie krijgen.

Daartoe volstaat echter niet de bouwinspanning van stad, gewestelijke bouwmatschappij en privé-initiatief. De leefbaarheid van de binnenstad moet ook in een kwalitatieve zin gevrijwaard en bevorderd worden. Vrijwarend zou men de beleidsoptie kunnen noemen elke ongekontroleerde uitbreiding van scolaire, administratieve en industriële inplantingen af te remmen. In een universiteitsstad als Leuven, die bovendien een belangrijke sekundaire en tertiaire funktie vervult, is het vastleggen van de bestemming van de gronden (A.P.A., B.P.A.'s) een essentiële beleidstaak. Het overheidsinitiatief gaat echter verder en wil de zones die voor huisvesting voorbehouden werden ook kwalitatieve kansen geven. In het ene geval zal dit de sloping inhouden van een krottenbuurt, in het andere geval de sanering van woningen en woonomgeving. In een historische stad sluit dit nauw aan bij een valorisering van het patrimonium. Dit kan gebeuren door een restauratie van monumenten en woningen, maar ook door een poging om via masterplannen nieuwbouw en historisch patrimonium in een harmonisch stedelijk landschap te integreren. Een derde prioriteit slaat op de infrastruktuur voor gemeenschapsdoe1einden in de socio-kulturele sfeer. Speciaal de sportvoorzieningen komen in reliëf, deels door de verdere uitbouw van het sportcentrum, maar al

(1) Cfr. de uitwerking van deze synthese in het doeleindenschema (separate opbergmap). 
evenzeer door het ombouwen van de Rijschool tot een polyvalente ruimte in de binnenstad. De traditionele kulturele voorzieningen krijgen uitbreiding naar de macro-schaal toe (kongreszaal, expohal1), maar vooralsnog minder op het micro-vlak (verenigingsleven).

De drie kern-doelstellingen zijn evenzoveel uitzichten van één fundamentele optie : het hart van de agglomeratie losrukken uit het schijnbaar onomkeerbaar proces van ontvolking, om het via de verfraaiing van de woonomgeving en het aanbod van een kwaliteitshuisvesting en veelzijdige voorzieningen aantrekklijk te maken als polyvalente city. Leuven wil de taken met regionale draagwijdte op zich nemen, maar niet ten nadele van de eigen leefbaarheid in de meest brede betekenis van het woord.

\subsection{DOELEINDENSTRUKTUUR KESSEL-LO}

\section{SITUERING}

Als gemeente is Kessel-Lo een kind van de 19e eeuw. Op de abdij Vlierbeek na, hadden zich in vroegere tijden geen nederzettingen van betekenis gevormd aan de oostelijke stadspoorten van Leuven. Toen kwam de industriele revolutie. Speciaal de doorbraak van de spoorwegen is voor de koncentratie van bedrijven en woonzones in de wijk 'Blauwput' van beslissende betekenis geweest. In 1829 werd de gemeente Kessel-Lo opgericht waarin Blauwput, dat tot Leuven hoorde, samengebracht werd met de wijk Beneden-Kessel en het agrarische gebied van de 'Lo' (ex Pellenberg).

Ondanks de verwoestingen tijdens de tweede wereldoorlog, draagt Blauwput nog sterk de sporen van zijn $19 \mathrm{e}$ eeuws verleden. De oude kernen Boven-Lo, Beneden-Kessel en Leming zijn slechts in de jongste jaren vlot toegankelijk gemaakt. De nieuwe woonwijken hebben zich vooral ontwikkeld in de tussenliggende zones. Op een totale oppervlakte van 1.321 ha. waren er einde 1972130 ha. bebouwd. Ondanks de sterke bouwinspanning blijft er dus nog heel wat potentiële groene ruimte over. Jammer genoeg is deze niet evenwichtig verdeeld. Kessel-Lo is dan ook op de eerste plaats een woongemeente voor 23.800 inwoners. Als grootste randgemeente leeft zij op de hartslag van het regionale centrum Leuven. 
1. Grond en woonbeleid

\subsection{GRONDBELEID}

\subsubsection{Plannen van aanleg}

De gemeente Kesse1-Lo beschikt niet over een grondregie. Het grondbeleid bestaat er dan ook hoofdzakelijk in terreinen te reserveren voor een bepaalde bestemming. Dit gebeurt via de klassieke middelen : een algemeen plan van aanleg (A.P.A.) en een reeks van bijzondere plannen van aanleg (B.P.A.'s). Het algemeen plan dateert van 1956 en is dringend aan een grondige herwerking toe. Het nieuwe A.P.A. is reeds ontworpen maar werd nog niet goedgekeurd, mede onder de druk van inspraakorganen, een aantal verenigingen en wijkcomités. De optie die wellicht de sterkste bezwaren oproept is de geplande autoweg (Jan Vranckxweg genaamd) die de Diestsesteenweg zou verbinden met de Tiensevest, via een grotendeels vrijgehouden tracé dat echter de woonwijk van de Platte-Lo doorkruist (1). Het nieuwe on-officiële A.P.A. wordt echter door de gemeentelijke beleidsinstanties als richtinggevende norm gehanteerd.

Zowat driekwart van het grondgebied wordt door B.P.A.'s bestreken. Niet betrokken zijn vooral de wijk Boven-Lo, een eerder ruraal gebied dat volgens het ontwerp van gewestplan niet in aanmerking komt als bouwzone, en het eveneens minder uitgebouwd gebied aan weerszijden van de Sneppenstraat, waarin de uitgebreide groenzone van de 'Schoolbergen' gelegen is.

\subsubsection{Gemeentelijke interventie}

Aangezien Kesse1-Lo niet over een grondregie beschikt, mist het een soepel instrument om gronden te reserveren op halflange of lange termijn. Op korte termijn intervenieert het gemeentebestuur echter via de gewone procedure om gronden te verwerven die onmiddellijk weer doorverkocht worden aan bouwmatschappijen of industrieën (2).

(1) Zie verder onder infrastruktuurbeleid.

(2) Zie verder onder tewerkstellingsbeleid : 3.1 . 


\subsection{SOCIALE WONINGBOUW}

Drie instanties zijn in Kesse1-Lo betrokken bij de sociale woningbouw : de gewestelijke bouwmaatschappij 'Heuvelhof', de bouwmaatschappij 'Onze Toevlucht' en de Nationale Landmaatschappij. Het is duidelijk dat via de gewestelijke bouwmatschappij 'Heuvelhof' het gemeentelijk beleid inzake sociale woningbouw gestalte krijgt. Dit blijkt niet alleen uit de omvang van de bouwinspanning, maar ook uit het impakt van de politieke meerderheidsgroep in de gemeenteraad op het beheer van de bouwmaatschappij. De bouwmaatschappij 'Onze Toevlucht' blijft in dit overzicht buiten beschouwing omdat ze niet 'bouw-aktief' is en enkel nog woningen onderhoudt en verhuurt. De Nationale Landmaatschappij van haar kant heeft wel een aantal woningen gebouwd in de omgeving van de Nachtegalenlaan maar dit blijkt een geisoleerd initiatief te zijn dat dan ook weinig beleidsrelevant is.

Onze aandacht koncentreert zich dus op de bouwmatschappij 'Heuvelhof' die sinds 1970 een gewestelijke aktiradius heeft gekregen, maar qua oorsprong en qua hoofdaktiviteit op Kessel-Lo gericht is.

Deze omvorming tot gewestelijke bouwmaatschappij beoogde geen aansluiting bij of oriëntatie naar de centrumstad, maar had enkel betrekking op een territoriale uitbreiding tot de gemeenten Linden, Holsbeek, Blanden en Korbeek-Lo. Geen schaalvergroting dus die een zekere eenheid in het bouwbeleid van het stadsgewest in de hand zou kunnen werken.

Het gemeentebestuur zelf neemt geen initiatieven meer als bouwheer. Dit heeft wellicht te maken met het minder gunstig resultaat van de uitbouw in eigen beheer van de Rerum-Novarumijk in 1959-60. De motivering is eerder van pragmatische aard : waarom optreden als bouwheer wanneer men hiertoe niet uitgerust is met gekwalificeerd personeel, terwij1 de bouwmatschappij gelijkaardige objektieven veel efficiënter kan realiseren ? Bij deze gedachtengang is het wel nuttig te bedenken dat de criteria en normen voor de sociale woningbouw sinds 1960 ruimer zijn geworden, zodat de 'middenkategorie' van woningen waar het toenmalig gemeentelijk initiatief op gericht was, thans ook door de bouwmaatschappij bestreken kan worden. 
In de ontwikkeling van de sociale woningbouw te Kessel-Lo (zowat 300 woongelegenheden sinds 1968) zijn een drietal elementen aan te stippen :

1. De aanvragen komen steeds minder van grote gezinnen, maar vooral van jonge gezinnen $(40 \%)$ en bejaarden (30\%). Voor het projekt 'Groeneweg' bv. voorziet men nog $15 \%$ van de beschikbare woonruimte voor grote gezinnen. De bouwmatschappij onderzoekt jaarlijks de evolutie in de kategorieën van aanvragers, om hierop haar beleid te kunnen afstemmen. Ook alleenstaanden (2\%) en gehandikapten ( $1 \%$ ) doen beroep op de sociale woningbouw. Dit veronderstelt een vrij grote differentiatie van het woonruimte-aanbod. Gestreefd wordt naar een harmonische spreiding van de verschillende bevolkingskategorieën. Ook daar waar woningen of appartementen speciaal ingericht werden voor bejaarden of gehandikapten, is tevens woonruimte voorzien voor (jonge) gezinnen.

2. De differentiatie wordt nog in de hand gewerkt door de grondprijzen. In de dichtbebouwde zones wordt meer en meer aan hoogbouw gedaan en varieert het aanbod van studio's tot grote appartementen.

3. Niet enkel de kwaliteit en het konfort van de woonruimte als dusdanig - en dus ook de prijs - zijn de jongste jaren snel gestegen. Ook aan het woonmilieu wordt meer aandacht besteed. Opmerkelijk zijn bv. de multifunktionele gemeenschapsruimten in de grote bouwprojekten, waarbij vooral gedacht werd aan de ontspanning van de oudere bewoners. De esthetische en milieu-verantwoorde vormgeving van de onmiddelijike woonomgeving wordt stilaan als vanzelfsprekend beschouwd. In het projekt 'Groeneweg' bv. zijn 4 ha van de 9 bestemd voor groenruimte. Globaal zou men kunnen stellen dat er in Kesse1-Lo een reële inspanning gebeurt om kwalitatief hoogstaande en gedifferentieerde woonruimte aan te bieden aan de lagere inkomensklassen. Gelet op de vrij hoge bouwinspanning in de privé-sektor werkt dit beleid inzake sociale woningbouw ontegensprekelijk een evenwichtige spreiding van de bevolkingskategorieen in de hand. 


\subsection{PRIVE-WONINGBOUW}

De woningbouw heeft in Kesse1-Lo een sterke expansie gekend zodat men mag spreken van een typische woongemeente. In 1972 nam het aantal woongelegenheden toe met 134, in 1973 met 227.

Aan de verkavelaars worden hoge kwaliteitseisen gesteld inzake de aan te leggen infrastruktuur. Maar ook de ruimte voor gemeenschapsvoorzieningen moet door de verkavelaar gereserveerd en gedragen worden. Zo bv. is in de verkaveling 'Kesseldal' 1 ha. vrijgehouden voor kollektieve voorzieningen, waaronder een $k$ leuterschool.

Globaal beschouwd kan men stellen dat de gemeente Kesse1-Lo t.a.v. de privé-woningbouw een weinig dirigistisch beleid voert. Behoudens de eisen inzake verantwoorde inplanting en kwaliteit van het onmiddellijk woonmilieu, heeft men hier niet te maken met een kwantitatieve woonplanning op lange termijn. De overheid laat veel ruimte aan het privéinitiatief en er is geen sprake van kontingentering. Hoelang zulke politiek op het toch beperkte territorium vol te houden is, blijkt niet in vraag te komen.

\subsection{SANERING}

De sanering van ongezonde- en krotwoningen is vooral urgent in de wijk Beneden-Kessel (Wilselse steenweg). Een globale aanpak van het probleem stuit echter op de weerstand van de bevolking. In het verleden gebeurde er dan ook omzeggens niets. In 1974 wordt een lening van 2,2 miljoen F. opgenomen om op enkele plaatsen de meest dringende gevallen te saneren. Een gemeentelijk reglement garandeert de afbraak van krotwoningen op gemeentekosten, ook indien ze geïsoleerd staan. Tevens zijn de betrokkenen verzekerd van een absolute prioriteit bij het aanvragen van een nieuwe woongelegenheid bij de bouwmatschappij Heuvelhof. Toch kan men zich moeilijk van de indruk ontdoen dat de inertie of onmacht van het gemeentelijk beleid in dit domein te maken heeft met de te kleine schaal waarop het probleem aangepakt wordt. In het (nog niet goedgekeurde) algemeen plan van aanleg wordt het hele gebied van de N.M.B.S.-hoofdwerkplaats in het oude deel van Blauwput als te saneren zone aangegeven. 
Het gat hier om een omvangrijk en ambitieus plan van stadsvernieuwing dat de klassieke saneringsmaatregelen ver overstijgt. Naast woonkomplexen zijn dit gebied immers ook socio-kulturele en handelsvoorzieningen toegedacht. Verder dan een eerste voorontwerp staat men nochtans niet, ook al omdat de voorwaarden waaronder de N.M.B.S. wil vertrekken vooralsnog niet op te brengen zijn. Ondanks het feit dat een projekt van zulke omvang Kesse1-Lo een 'hart' zou'geven, kunnen we er in deze bespreking niet verder op ingaan. Daartoe is de toekomst nog te onduidelijk.

2. Socio-kultureel, milieu- en welzijnsbeleid

\subsection{MILIEUBELEID}

Kesse1-Lo is een typische woongemeente. Slechts een paar industriële bedrijven en enkele ambachtelijke ondernemingen zijn op het grondgebied van de gemeente gevestigd, en deze veroorzaken geen noemenswaardige milieuhinder.

De aandacht van het gemeentebestuur is dan ook veeleer gericht op het vrijwaren en het valoriseren van de groenzones. Enerzijds heeft dit te maken met de kwaliteit van het woonmilieu. De intensieve bouwinspanning moet samengaan met een planmatig reserveren of aanleggen van groene ruimten die partieel aangewend kunnen worden voor aktieve rekreatie in de onmiddelijjke woonomgeving. Anderzijds komt in een ruimer perspektief ook de volksgezondheid ter sprake ('groene long'), en wordt van de overheid verwacht dat ze het groenpatrimonium vrijwaart en zoveel mogelijk ter beschikking stelt van de ganse bevolking met het oog op aktieve en passieve rekreatie.

Langs drie verschillende wegen tracht het gemeentebestuur deze doelste1ling te realiseren :

\subsubsection{Via de interventie van het provinciebestuur}

Op deze wijze werden het Leopoldspark en het Vijverpark door de provincie Brabant verworven en gevaloriseerd tot een provinciaal domein. Dit 
park van 45 ha. wordt in de toekomst uitgebreid met een zone van 50 ha. die eerder voor 'wandelgroen' bestemd is en als 'Vlierbeek veld' ook de omgeving van de abdij vlierbeek vrijwaart.

2.1.2. Via B.P.A.'s en het A.P.A.

In het (nog niet goedgekeurd) nieuw algemeen plan worden niet enkel de woonzones afgebakend, maar wordt tevens de kwantiteit van de bebouwing per ha. gepreciseerd. Op deze wijze kan men bepaalde zones beschermen tegen al te kompakte bebouwing, hetgeen de woonomgeving ten goede komt. Daarnaast zijn uiteraard de a1 dan niet beschermde landbouwgebieden aangegeven, evenals de zones voor nijverheid. Onze aandacht gaat hier echter vooral naar de gereserveerde groenzones. Deze kunnen in privê-bezit zijn en voorlopig ook blijven : bv. Predikherenberg, Lobergen, Zavelstraat, Schoolbergen en Lemingsbergen. Andere zones zijn in het gewestplan bestemd voor de aanleg voor groenruimten, bv. het gebied tussen de Dijle en de spoorweg Leuven-Aarschot. Tenslotte komen enkele zones meer onmiddellijk in anmerking voor uitbouw als aktief of passief rekreatiegebied, hetgeen een overheidsinterventie zal vereisen : bv. het reeds genoemde Vlierbeekveld en de uitbreiding van het domein Kesselberg.

\subsubsection{Via gemeentelijke interventie}

Indien men het gemeentelijk park Heuvelhof (waarin ook het gemeentehuis is gelegen) buiten beschouwing laat, kan men vaststellen dat het slechts de laatste jaren is dat het gemeentebestuur zelf groene zones aankoopt om ze te vrijwaren of toegankelijk te maken.

Te vermelden zijn vooral volgende aankopen :

- de Kesselberg, die uitgebouwd wordt tot een volwaardig natuurpark. Dit domein zou in de toekomst nog aanzienlijk uitgebreid worden.

- het domein S.A.M. aan de Koetsweg, waarin een gebouw staat dat als ontmoetingsruimte wordt gevaloriseerd. Zie verder onder kultuurbeleid (2.3.).

- het domein 'Heiberg' aan de Heidebergstraat waarin een gebouw staat dat als ontmoetingscentrum ingericht wordt, speciaal ten behoeve van de jeugd (zie verder onder kultuurbeleid : 2.3.). 
- een gedeelte van het park Michotte (2,2 ha. van de 3 ha.) aan de P1atte-Lostraat, waarbij een overeenkomst kon bereikt worden met de bouwfirma die hier twee appartementsgebouwen zal optrekken.

Deze overheidsinterventie inzake het vrijwaren en het aanleggen van groenzones wordt zeex nauwlettend geobserveerd en geëvalueerd door milieubewuste aktiegroepen, verenigingen en inspraakorganen. Men mag wel stellen dat de aanzienlijke inspanningen van het gemeentebestuur inzake planning en vooral inzake aankoop mede onder druk van de publieke opinie te verklaren zijn. Zeker indien men de huidige opties en lange-termijnplanning vergelijkt met de inspanningen van vorige besturen komt de nieuwe klemtoon nog beter uit de verf.

\subsection{SPORTBELEID}

Sinds de uitbouw van het 'openluchtcentrum' (sportterreinen, vooral dan een uitgerust voetbalveld met atletiekpiste) in de jaren 1954-1956, is er inzake investeringen voor sportakkomodatie nog weinig te melden. Aanvullende voorzieningen werden nog wel gerealiseerd in de periode 1959-1964, maar tijdens het daaropvolgende mandaat werd helemaal niets meer ondernomen. De grote optie van het huidig bestuur valt dan ook op : de bestaande infrastruktuur wordt uitgebouwd tot een volwaardig sportcentrum, met als blikvangers het zwembad en de sporthal. Van de uitgaven in de gewone dienst gaat uiteraard het leeuwenaandeel naar de aflossing van de schuld i.v.m. de uitbouw van het sportcentrum. Bij de overdrachten kan men de steun noteren aan de jaarlijkse sporten rekreatieve week (130.000 F.), georganiseerd door sportraad en jeugdraad. Ten behoeve van sport- en jeugdorganisaties worden bovendien sportbenodigdheden (o.a. sportkoffers) ter beschikking gesteld. Voorlopig is er slechts één personeelsid, belast met onderhoud en toezicht.

Om een beleid op lange termijn te kunnen voeren inzake sport- en rekreatieve voorzieningen, heeft het gemeentebestuur zich laten adviseren door een privé-studiegroep. Deze makte een uitvoerige inventaris op van alle bestaande voorzieningen en vulde deze aan met voorstellen. 


\subsection{KULTUURBELEID}

Als grote opties kunnen hier weerhouden worden :

- het ter beschikking stellen van ruimte voor socio-kulturele aktiviteiten ;

- het stimuleren van het overleg tussen de diverse socio-kulturele verenigingen en het steunen van gemeenschappelijke aktiviteiten;

- de restauratie en het valoriseren van het kultureel patrimonium, in hoofdzaak dan het V1ierbeek-domein (abdijkerk, hoeve).

Het probleem van de socio-kulturele infrastruktuur wordt door het huidige kollege systematisch aangepakt. Met de kultuurraad werd overleg gepleegd over de optimale spreiding en/of centralisatie van deze infrastruktuur, terwij1 ook een studiebureau bij de planning werd betrokken. Ten aanzien van het huidig aanbod an ruimte voor socio-kulturele doeleinden, voornamelijk parochiezalen, stelt zich echter een delikaat probleem. Het gemeentebestuur wil beslist de bestaande infrastruktuur aanpassingskansen geven alvorens eventuee 1 in nieuwe wijkcentra te investeren. Vandaar dat een gemeentelijk reglement een toelage voorziet van $60 \%$ t.b.v. verbeteringswerken aan gemeenschapslokalen. Op de begroting 1974 werd hier $636.000 \mathrm{~F}$. voor uitgetrokken. Deze subsidiëring weegt dan ook zwaar door in de rubriek overdrachten. Personeels- en werkingskosten blijven miniem. Naast een part-time administratieve kracht voor de muziekakademie, is er slechts 1 personeelslid onder deze rubriek aan te stippen belast met het onderhoud van de gemeentelijke feestzaal.

Een definitieve optie in verband met de uitbouw van een gemeentelijk kulturee 1 centrum is nog niet genomen. Het aangekochte S.A.M.-gebouw aan de Koetsweg kan hier bezwaarlijk voor doorgaan, ook al wordt het als dusdanig vermeld in de begroting. Na aanpassingswerken werd het gebouw - inmiddels omgedoopt tot het gemeentelijk domein 'De Bron' immers verhuurd aan de Stichting Lodewijk De Raet voor het volkshogeschoolwerk.

Het domein 'Heiberg' aan de Heidebergstraat is integendeel wèl bedoeld voor lokaal gebruik, maar dan hoofdzakelijk als socio-kulturele ruimte voor jongeren. Deze investering ging zoals deze i.v.m. het S.A.M.-gebouw 
gepaard met de aankoop van een belangrijke groenzone (1). De valorisering van 'Heiberg' werd toevertrouwd an een gelijknamige v.z.w., die ruime middelen krijgt om de jeugdwerking van hieruit te animeren (2). Het kunstonderwijs tenslotte beperkt zich tot een afdeling van het Leuvens muziekconservatorium. Een eigen gemeentelijke bibliotheek of discotheek is niet voorhanden.

Globaal gezien kan men vaststellen dat in de kulturele sektor thans enkele investeringen gebeuren, nadat dit domein volkomen onontgonnen was gebleven.

\subsection{JEUGDBELEID}

A1s belangrijke investering kan hier nogmaals de aankoop van het domein 'Heiberg' aangehaald worden, omdat het als ruimte socio-kulturele aktiviteiten op de eerste plaats voor jeugdwerk bestemd is. De gemeentelijke interventie beperkt zich hier echter niet tot de ankoopsom, enkele aanpassingswerken of het onderhoud van het domein. Via de v.z.w. 'Heiberg', waarin het gemeentebestuur vertegenwoordigd is, wordt in 1974 een jeugdwerker aangetrokken die naast de animatie van het jeugdcentrum ook aan bredere jeugdwerking (vorming, begeleiding) zal doen. De bezoldiging van deze jeugdwerker wordt integraal gedragen door de gemeente via een toelage aan de v.z.w. Dit initiatief is wellicht belangrijker dan de financiële inspanning ( 400.000 F.) zou doen vermoeden. Het leidt een nieuwe koers in, waarbij de overheid zich niet meer beperkt tot het ter beschikking stellen van ruimtelijke akkomoda-. tie, maar onrechtstreeks intervenieert bij het kreëren van vormingsen begeleidingskansen. De klassieke 'aanvullende rol' t.a.v. het privé-initiatief wordt hierdoor heel wat ruimer geïnterpreteerd.

Naast de tussenkomst in de sport- en kreatieve week $(130.000$ F.) (3) zijn er de traditionele subsidies aan jeugdclubs en -bewegingen ( $145.000 \mathrm{~F}$.)

(1) Zie milieubeleid 2.1.

(2) Zie jeugdbeleid 2.4.

(3) Zie ook sportbeleid 2.3. 
maar ook toelagen voor de uitrusting van jeugdlokalen (100.000 F.).

\subsection{WELZIJNSZORG}

\subsubsection{Bejaardenbeleid}

Tot de socio-kulturele taaksfeer kan de oprichting gerekend worden van de vzw SO.KE.LO (Samenlevingsopbouw Kesse1-Lo). Gegroeid vanuit een onderzoeksprojekt naar de behoeften van de bejaarden, waarbij de bejaarden zelf aktief werden betrokken, wil deze welzijnsraad allereerst de verdere uitbouw van individuele en kollektieve voorzieningen voor bejaarden mee plannen en bevorderen. Ruimer gesteld komt hierbij de integratie van de bejaardenbevolking in de samenleving ter sprake, waarbij alle instanties en geledingen betrokken worden. De gemeentelijke toelage aan de vzw, waarin het gemeentebestuur en de coo vertegenwoordigd $z i j n$, omvat de wedde van een opbouwwerker (420.000 F.).

Het gemeentelijk bejaardenbeleid wordt uitgewerkt in dialoog met de raad van de derde leeftijd waarin de diverse bonden van gepensioneerden vertegenwoordigd zijn.

\subsubsection{Gezinsbeleid}

Het gezinsbeleid krijgt gestalte in dialoog met een ruime gezinsraad. De aandacht gaat speciaal naar kinderdagverblijven en naar gezinshulp. Een gemeentelijk reglement voorziet een financiële tussenkomst bij de installatie van peutertuinen en intervenieert ook in de werkingskosten ten behoeve van de lagere inkomenskategorieën. Deze laatsten kunnen dank zij de overheidsbemoeiing rekenen op een bepald percentage van de beschikbare plaatsen. Twee peutertuinen werden aldus opgericht door privé-groepen met uiteenlopende ideologische achtergrond.

Ook t.a.v. het opvangen van de allerjongsten is het overheidsinitiatief eerder ruggesteunend. Een 30-tal onthalgezinnen worden erkend, gesuperviseerd en financieel gesteund. Slechts in de ontworpen Vlierbeekwijk is een kinderkribbe gepland.

De gezinshulp gebeurde tot dusver vanuit twee organisaties, met gemeentelijke financiële steun. Mede omwille van het ontoereikend aanbod, 
zal' een eigen gemeentelijke dienst opgericht worden met aanvankelijk drie gezinshelpsters.

\subsubsection{Maatschappelijke dienstverlening}

Een gemeentelijke sociale dienst werd opgericht met de uitdrukkelijke bedoeling niet enkel te bemiddelen bij de oplossing van individuele probleemgevallen, maar tevens bij te dragen tot een brede bewustwording bij de bevolking i.v.m. de welzijnsproblematiek. In een eerste faze wordt een 'tele-dienst' uitgebouwd die de belangeloze onderlinge hulpverlening der bereidwillige burgers wil struktureren en begeleiden.

\section{Sociaal-ekonomisch en infrastruktuurbeleid}

\section{1. TEWERKSTELLINGSBELEID}

De gemeente Kesse1-Lo intervenieert bij de inplanting van bedrijven via het aankopen van terreinen die ze - sterk verlieslatend - weer doorverkoopt aan de bedrijven. Kontraktueel wordt hierbij echter gepreciseerd dat een bepaalde getalsterkte aan personeel aangehouden zal worden en ook een zeker quantum aan drijfkracht afgenomen. Na een belastingsvrije aanloop van 5 jaar rekupereert de gemeente de investering via de opbrengst der belastingen op personeel en drijfkracht. Deze regeling werd reeds in drie gevallen toegepast $0 . \mathrm{m}$. bij de inplanting van RAYCHEM. In één geval werd het industrieel projekt voortijdig afgebroken en heeft de gemeente de verlies-som bij de grondafstand teruggevorderd en -bekomen.

\subsection{INFRASTRUKTUURBELEID}

\subsubsection{Kwaliteitsverbetering}

De gemeente Kessel-Lo vertoonde in het midden van de zestiger jaren een belangrijke achterstand wat de kwaliteit van het wegennet betreft. Bovendien moesten heel wat nieuwe verbindingswegen aangelegd of verbeterd 
worden omwille van de grote bouwinspanning en de sterk toegenomen bevolking.

Tijdens het mandaat 1965-1970 werden dan ook belangrijke investeringen gedaan inzake wegeninfxastruktuur, inklusief het rioleringsnet en de wegverlichting ( $86 \%$ van de totale investeringen). In absolute cijfers zet zich deze trend door tijdens het huidige mandaat, zij het relatief minder opvallend ( $42 \%$ ), ook al omdat de aandacht afgeleid wordt naar de grote investeringen in groenzones en socio-kulturele infrastruktuur. Bij de investeringen dient ook de participatie (1,5 miljoen F.) aan het interkommunal (Interleuven) opgezette waterzuiveringstation aangestipt te worden.

\subsubsection{Verkeersontsluiting}

Het samenvallen van de 1okale verkeersstroom met het intensief interregionaal en zelfs international verkeer, veroorzaakt op de spitsuren aanzienlijke moeilijkheden. Speciaal het probleem van de invalswegen naar Leuven (Diestsesteenweg en Tiensesteenweg) staat hierbij centraal. Al overstijgt de probleemoplossing het gemeentebestuur, toch is het aktief betrokken bij het zoeken naar alternatieve invals- of afleidingswegen. Twee voorstellen verdienen speciaal de aandacht. Een afleidingsweg van de Diestsesteenweg in de richting van de Tiensesteenweg en de $\mathrm{E} 5$ wordt voorzien vanaf Lubbeek (De Mo1). Deze weg zou ter hoogte van de Lo-bergen de gemeente even doorkruisen. Meer rechtstreeks is Kesse1-Lo betrokken bij de geplande invalsweg die vanaf de Diestsesteenweg (ter hoogte van de Jan Davidsstraat) via de Platte-Lo woonwijk naar de Tiensevest zou Iopen, waarbij de Martelarenlaan gekruist en de spoorweg overbrugd moet worden. Het tracé wordt in het A.P.A. vrijgehouden maar ontmoet veel weerstand omwille van het doorkruisen van een belangrijke woonwijk (1). Een beslissing is vooralsnog niet gevallen. Intussen blijft het ontwarren van de verkeersknoop een dagelijkse prioriteit voor de Kesselse politie en is de verkeersveiligheid bijzonder bedreigd. Het kan dan ook geen verwondering wekken dat een oplossing van deze problematiek centraal staat bij de beleidsvoerders.

(1) Zie hoger onder grondbeleid : 1.1 . 
4. Interne bestuursorganisatie

4.1. PERSONEELSKADER

\begin{tabular}{|c|c|c|c|c|}
\hline & \multicolumn{2}{|c|}{ Effektief bezette funkties } & \multirow[t]{2}{*}{ Vakatures } & \multirow[t]{2}{*}{ Totaal } \\
\hline & Ful1-time & Part-time & & \\
\hline Algemene administratie & 20 & & 2 & 22 \\
\hline Politie & 21 & & 2 & 23 \\
\hline Technisch personeel & 36 & 1 & 1 & 38 \\
\hline Volksgezondheid & 2 & 1 & & 3 \\
\hline $\begin{array}{l}\text { Personeel ter behartiging } \\
\text { van taken uit de } \\
\text { socio-kulturele sfeer : }\end{array}$ & & & & \\
\hline Groenzones + milieuzorg & 10 & & & 10 \\
\hline Sport & 1 & & & 1 \\
\hline Ku1tuur & 1 & & & 1 \\
\hline Jeugd & & & 1 & 1 \\
\hline \multirow[t]{2}{*}{ Welzijnszorg } & 1 & & & 1 \\
\hline & 92 & 2 & 6 & 100 \\
\hline
\end{tabular}

Het relatief hoog aantal personeelsleden in de rubriek 'groenzones en milieuzorg' is te verklaren door de uitbouw van de dienst plantsoenen, die instaat voor aanleg en onderhoud van de bestaande en verworven groenzones. Een uitbreiding is hier beslist nog te verwachten. Ook de personeelsleden die respektievelijk onder 'Sport' en 'Kultuur' vermeld worden zijn in feite onderhoudskrachten. De vakature onder 'Jeugd' is daarentegen uitgeschreven voor een jeugdwerker. Het ziet er echter naar uit dat deze eerder aangetrokken zal worden door de v.z.w. Heiberg met integrale wedde-toelage vanwege de gemeente. Het personeelslid dat onder 'Welzijnszorg' gerangschikt wordt, is de maatschappelijke assistente van de gemeentelijke sociale dienst.

Indien de hiërarchische struktuur bij het personeel van de algemene administratie erg traditioneel opgebouwd is ( 1 bureauchef, 4 onderbureauchefs, 7 opstellers, enz.), dan valt het bij nader toezien toch op dat de gemeentesekretaris ( $\mathrm{dr}$. iuris) niet geassisteerd wordt door een aantal 
stafmedewerkers. Tussen de administratieve top en de uitvoeringsambtenaren is er een feitelijk vaccum. Staffunkties als adviseren en plannen komen dan ook nauwelijks aan bod. Dit is ten dele te verklaren door de lage scholingsgraad van het personeel, maar heeft ook te maken met de visie van de beleidsverantwoordelijken op de rol van de administratie.

\subsection{KOLLEGE VERSUS ADMINISTRATIE}

Bij de verantwoordelijken van de meerderheidspartij is er een tendens vast te stellen naar een zekere 'professionalisering' van het schepenambt. Niet dat er gestreefd zou worden naar full-time schepenen, maar we1 dat voor elke beleidssfeer een deskundige kracht het ambt zou opnemen. Dit streven kan geslaagd genoemd worden voor wat de sektoren openbare werken, financiën en matschappelijke welzijnszorg betreft. Voor de kulturele sektor die dank $z i j$ een additioneel schepenmandaat vanaf 1971 extra aandacht kreeg, werd eenzelfde formule gezocht. Hier nochtans is dit streven naar professionalisering in deze zin mislukt dat het tussen de aangezochte schepen en de collegae tot een open breuk is gekomen. De schepen in kwestie, uitgesproken deskundig maar nieuweling in politicis, werd van alle opdrachten ontheven. Binnen het kollege geeft dit uiteraard aanleiding tot sterke spanningen. De besluitvorming als dusdanig wordt er echter niet door verlamd.

De deskundigheid van de schepenen vindt een ruimer toepassingsgebied dan enkel de beleidsvoorbereiding en -beslissing. Hun aandacht gaat al evenzeer naar de konkrete vormgeving van de beleidsrealisatie. Zij nemen dan ook de dagelijkse leiding op zich van de sleutel-diensten, zodat beleid en beheer in dezelfde handen liggen. Dit optreden houdt ongetwijfeld veel voordelen in : de remmende administratieve geledingen zijn onbestaand, een direkt kontakt tussen de schepen en de ondergeschikte uitvoeringsambtenaren laat een snel en efficiënt optreden toe. Bovendien is dit een erg zuinige beheersvorm, en de bewindslieden laten dan ook niet na hierop te wijzen. Toch zijn er ook risiko's verbonden aan dit samenvallen van schepenambt en administratieve kaderfunktie. Uitgesproken deskundigheid en intensieve, financieel-belangeloze inzet kunnen een tijdlang manifest aanwezig zijn, maar deze bestuurstraditie loopt de kans 
aan inhoudelijke kracht te verliezen bij een volgend mandaat met andere titularissen.

Anderzijds is het slechts op een beperkte, overzichtelijke schaal en ten aanzien van overzichtelijke problemen van dit 'kumuleren' van beleidsen beheersfunkties denkbaar is. De meer komplexe planning wordt zonder meer doorgespeeld aan externe studiebureaus die op het interkommunaal vlak kunnen liggen, maar zich niet zelden in de privé-sfeer situeren. Dit is vooral waar voor de behoeftenanalyse en de planning inzake de socio-kulturele en sportinfrastruktuur. Maar ook de ontwerper-planoloog die kontraktueel aan het bestuur verbonden was, werd geleidelijk ter zijde geschoven ten voordele van studiebureaus die beter aan totaalplanning kunnen doen, maar waarin het kollege toch vooral zijn eigen visie en opties herkent. Indien dan ook vastgesteld wordt dat de administratieve top onderbezet is wat deskundige mankracht betreft, kan dit mede verklaard worden vanuit de vrij traditionele visie van de beleidsverantwoordelijken op de rol van de ambtenaar.

De politieke besluitvorming wordt dus in haar formulering en uitwerking als het exklusief terrein van de politici beschouwd. Waar de aard van de problematiek het vereist verkiezen ze externe studiebureaus boven de eigen administratie, hetgeen een ruimere marge openlaat voor de uiteindelijke beslissing. Het zal evenwel duidelijk zijn dat deze houding mede bepaald wordt door de schaal waarop de besluitvorming plaats vindt. Met name moeten de feitelijk beperkte mogelijkheden om gespecialiseerde ambtenaren aan te trekken verrekend worden in een totaalappreciatie.

\section{Bespreking van het uitgavenpatroon}

Reeds bij een eerste blik op de overzichtstabellen van de uitgaven in de gewone dienst springen enkele markante sektoren in het oog. Indien we bv. uit de begrotingscijfers voor 1974 deze uitgavenposten lichten die meer dan $5 \%$ uitmaken van het totale uitgavenpakket, bekomen we volgend overzicht : 


\begin{tabular}{l|c|c|c|c}
\hline Funkties & $\begin{array}{l}\text { uitgaven per } \\
\text { inwoner }\end{array}$ & $\begin{array}{l}\text { in \% van het } \\
\text { total }\end{array}$ & $\begin{array}{l}\text { netto-uitgaven } \\
\text { per inwoner }\end{array}$ & $\begin{array}{l}\text { in \% van het } \\
\text { totaal }\end{array}$ \\
\hline $\begin{array}{l}\text { Algemene } \\
\text { administratie }\end{array}$ & 631 & 13,84 & 625 & 16,57 \\
$\begin{array}{l}\text { Justitie-Po- } \\
\text { litie }\end{array}$ & 474 & 10,40 & 474 & 12,57 \\
$\begin{array}{l}\text { Verkeer-Wegen } \\
\text { Waterlopen }\end{array}$ & 1100 & 24,11 & 959 & 25,43 \\
$\begin{array}{l}\text { Volksontwik- } \\
\text { keling en } \\
\text { Kunst }\end{array}$ & 804 & 17,64 & 583 & 15,46 \\
$\begin{array}{l}\text { Sociale Voor- } \\
\text { zorg en On- } \\
\text { derstand } \\
\begin{array}{l}\text { Ontsmetting, } \\
\text { reiniging, }\end{array}\end{array}$ & 337 & 7,39 & 310 & 8,22 \\
\begin{tabular}{l} 
huisvuil \\
\hline
\end{tabular}
\end{tabular}

Naast de onvermijdelijke funkties 'Algemene administratie' en 'JustitiePolitie', zijn het vooral 'Verkeer-Wegen-Waterlopen' (V.W.W.) en 'Volksontwikkeling en Kunst' (V.K.) die in reliëf komen. Het relatieve aandeel van V.W.W. Iigt echter quasi stationnair rond één kwart van de uitgaven, terwij1 V.K. vanaf de begroting voor 1973 plots haar aandeel in de nettouitgaven opvoert van $10 \%$ tot $15 \%$. Deze verschuiving kan belicht worden vanuit een opsplitsing van de uitgaven in de rubrieken personeel, werkingskosten, overdrachten en schuld. Hieruit blijkt dat het niet de personeelskosten of de werkingskosten zijn die V.K. zulk relatief gewicht gegeven hebben. De overdrachten zijn wel flink gestegen (tussen 1973 en 1974 van $59 \mathrm{~F}$ tot $92 \mathrm{~F}$ per inwoner), maar het is vooral de schuld i.v.m. de oprichting van het sportcentrum en de aankoop van groenzones die vanaf 1973 doorweegt (489 F/inw. en $27,83 \%$ van de totale schuld op de begroting 1974).

De overzichtstabellen (1) onderlijnen nogmaals de 'pointe' van de beleidsuitgaven in Kesse1-Lo. Dit vrij duidelijk geaksentueerd uitgavenpatroon zal sub 4.4.1. vergeleken moeten worden met dit van Leuven en Herent, in een poging deze 'eenzijdigheid' te situeren en te verklaren.

(1) In bijlage $3 \mathrm{C}$. 


\begin{tabular}{|c|c|c|c|c}
\hline Begrotingsjaar & $\begin{array}{l}\text { Personeels- } \\
\text { uitgaven }\end{array}$ & $\begin{array}{l}\text { Werkings- } \\
\text { kosten }\end{array}$ & Overdrachten & Schuld \\
\hline 1973 & 35,17 & 11,26 & 11,54 & 42,03 \\
1974 & 36,80 & 13,12 & 11,54 & 38,54 \\
\hline
\end{tabular}

6. Elementen van synthese (1)

Ondanks de handikaps die de besluitvorming binnen het kollege bedreigden komt uit het geheel van deze analyse een duidelijk reliëf naar voor. De prioriteiten zijn bekend : kwaliteitsverbetering van het wegennet, verkeersontsluiting, sociale woningbouw, sportinfrastruktuur, behoud van groenzones, betere maatschappelijke voorzieningen. Het is echter belangrijk te noteren dat deze toch wel klassieke taken opgenomen worden vanuit een vrij traditionele visie op de rol van de overheid. Mede onder invloed van de dominante partij (de Christelijke Volkspartij) die een homogeen kollege kon vormen dat over een ruime meerderheid beschikt, is de overheisinterventie suppletief te noemen in de socio-kulturele sfeer. Het is niet toevallig dat Kessel-Lo geen echt kultureel centrum op het getouw heeft staan, en al evenmin een gemeentelijke bibliotheek. Ook in de welzijnssektor is het overheidsinitiatief beperkt, al worden hier wel (peutertuinen, bejaarden- en gezinshulp) stappen gezet om het ontbrekende privé-initiatief aan te vullen. Naast een zeer aktieve sociale-woningbouwpolitiek tenslotte, is het grond- en huisvestingsbeleid eerder diskreet wat de overheidsbemoeiing betreft. Globaal zou men kunnen stellen dat het gemeentebestuur een planmatig en kwalitatief-verantwoord beleid wil voeren in de richting van de noodzakelijke gemeenschapsvoorzieningen, dit ter aanvulling en/of ter ondersteuning van het privé-initiatief. Deze optie is vooral relevant in een vergelijkend perspektief. Zowel Leuven als Herent worden immers bestuurd door een B.S.P.-C.V.P. koalitie, hetgeen noodzakelijkerwijze aksentverschillen meeb rengt.

(1) Cfr. de uitwerking van de synthese in het doeleindenschema (separate opbergmap). 
Een beleidssfeer die niet tot ons specifieke onderzoeksterrein behoort maar hier toch niet onvermeld mag blijven, is het gemeentelijk onderwijs. Op het grondgebied van de gemeente is een volledige gamma van kleuter-, lagere- en middelbare onderwijsvoorzieningen uitgebouwd in de beide schoolnetten, met uitzondering van een middelbare opleiding voor jongens in het vrij onderwijs. Dit is amper een lakune te noemen aangezien de middelbare scholen te Leuven vlot bereikbaar zijn. Ten aanzien van het hinterland vervullen de scholen van Kesse1-Lo een belangrijke funktie en ontlasten enigszins de exklusieve koncentratie in Leuven. De gemeente Kesse-Lo heeft de eigen lagere school echter opgegeven en overgedragen aan het Rijk.

Tegenover de vaststelling dat het gemeentebestuur in de gegeven omstandigheden de onderwijstaak niet als een eigen opdracht beschouwt, staat nochtans haar belangstelling voor de inplanting van de onderwijsvoorzieningen in agglomeratieverband. Het hoeft wel geen bewijsvoering dat de scholen in de binnenstad een zware opgave betekenen voor de stad Leuven, met name vanuit verkeerstechnisch standpunt, terwij1 ze anderzijds financieel weinig bijdragen. Ook voor de scholen zelf, die slechts weinig uitbreidingskansen krijgen en dan nog tegen bijzonder hoge prijzen, wordt de situatie onhoudbaar. De toegenomen vraag naar meer beperkte klassen en vooral naar sport- en rekreatieve infrastruktuur is hier niet vreemd aan. Een planmatige spreiding over de agglomeratie, met de nadruk op een dekoncentratie naar de rand, dringt zich op.

Het gemeentebestuur van Kesse1-Lo heeft zich reeds jaren geleden bereid verklaard de dekongestie van de binnenstad mogelijk te maken, door het beschikbaar stellen van terreinen voor onderwijsvoorzieningen. Indien hierop niet ingegaan werd is dit deels te verklaren door de hoge uitgaven van zulk transfert, maar toch ook door het gebrek aan planning en eenheidsvisie op agglomeratievlak. Juist omdat een vergelijkbare onderwijsdekoncentratie in andere agglomeraties wel mogelijk bleek (bv. te Brugge), is deze problematiek indikatief voor het vakuum aan agglomeratie-overleg.

Dit ontbreken van een breder perspektief dan het gemeente-niveau relativeert de validiteit van expliciete beleidsdoeleinden als de optimale verhouding tussen bevolking en bebouwde oppervlakte enerzijds en de to- 
tale beschikbare ruimte anderzijds, met inbegrip van de noodzakelijke reserves van groen en zones voor latere bouwinitiatieven. De oprechtheid van dit beleid kan angetoond worden, maar de betrekkelijkheid ervan is al even evident wanneer elk gemeentebestuur op eigen initiatief deze criteria interpreteert en hanteert. Een gemeentelijke beleidsanalyse moet dan ook in agglomeratieverband steeds getoetst worden aan de globale ontwikkelingen.

\subsection{DOELEINDENSTRUKTUUR HERENT}

\section{SITUERING}

De gemeente Herent heeft in het midden van de negentiende eeuw een twee-kernenstruktuur gekregen. Het historisch kerkdorp Herent, 3,5 km ten Noorden van Leuven gelegen aan de rijksweg naar Mechelen, kreeg toen een partner door de ontwikkeling van Wijgmaal, gelegen aan de vaart Leuven-Mechelen. Rijksweg en vaart, beide omstreeks 1750 aangelegd, hebben de ruimtelijke vormgeving van de gemeente in belangrijke mate bepaald. Ook nu nog vormt vooral de vaart een natuurlijke barrière tussen beide deelgemeenten. Slechts via één brug krijgt men vanuit Herent toegang tot Wijgmaal, dat zich nauw aansluitend bij de Remy-fabrieken ontwikkeld heeft.

Binnen beide deelgemeenten kan men een aantal wijken onderscheiden. De opsomming hiervan lijkt ons in dit verband minder belangrijk, omdat ze zich niet zelfstandig opstellen t.a.v. één der kernen. Uitzondering hierop vormt evenwel de wijk Kelfs in het uiterste Noorden van de gemeente. Zowel qua ligging als qua bevolkingsstruktuur sluit deze wijk nauw aan bij het meer landelijke Wakkerzeel, zelf een kerkdorp van Werchter.

De bevolkingstoename is vooral markant in de deelgemeente Herent. Dit heeft te maken met de grotere oppervlakte en vooral met de talrijke bouwprojekten. Einde 1970 telde de gemeente Herent op 1.740 ha 10.621 inwoners, waarvan er 3.252 in Wijgmaal en 7.369 in de deelgemeente Herent woonden. Sindsdien gaat de bevolkingscurve verder geleidelijk omhoog : 11.241 inwoners op 31.12.1973. 
De tweeledigheid van de gemeente Herent is niet alleen sociaal-ruimtelijk relevant. De deelgemeenten Herent en Wijgmaal vormen afzonderlijke territoriale samenlevingsverbanden, met name op het socio-kulturele vlak, hetgeen ook konsekwenties inhoudt voor de politieke opstelling. Het gemeentebeleid staat dan ook voor een keuze, een fundamentele optie : ofwel een poging doen om via een centrale inplanting van de nieuwe voorzieningen de beide deelgemeenten nader tot elkaar te brengen, ofwe1 aangepaste voorzieningen uitbouwen in elk van beide deelgemeenten. Het huidig B.S.P.-C.V.P.-kollege heeft deze laatste optie weerhouden.

1. Grond- en woonbeleid

1. 1. GRONDBELEID

1.1.1. Plannen van aanleg

Het is slechts sinds het aantreden van het huidig kollege dat men van een globaal en koherent beleid inzake ruimtelijke ordening kan spreken. Op een paar B.P.A.'s na, die ofwel door de evolutie achterhaald ofwel volledig gerealiseerd waren, bestonden er geen plannen van aanleg. Het gemeentebestuur heeft dan ook in 1971 absolute prioriteit gegeven aan het opmaken van een algemeen richtingsplan. Ofschoon dit plan, dat einde 1973 klaarkwam, geen bindende kracht bezit, verkoos men deze soepele formule boven een algemeen plan van aanleg. Het richtingsplan kan $n 1$. bijgestuurd worden inzover het in overeensteming blijft met het (ontwerp-) gewestplan, terwijl het voor intern-bestuurlijk gebruik toch de grote opties vastlegt. Het richtingsplan kwam ten andere nog net op tijd klaar om het gemeentebestuur in staat te stellen zinvol te dialogeren met het bestuur van de stedebouw en de ruimtelijke ordening alvorens het gewestplan definitief vorm krijgt. Op basis van de eigen planaktiviteit kon overeenstemming bereikt worden over een groot aantal voorstellen en detailamenderingen, zodat de gewestelijke en de lokale visie op de ruimtelijke ontwikkeling grotendeels konvergeren. Tegen deze soliede achtergrond wordt het nu mogelijk de bijzondere plan- 
nen uit te werken of te herzien.

\subsubsection{Gemeentelijke interventie}

Alhoewel vooralsnog geen gemeentelijke grondregie voorzien is, beperkt de overheid zich niet tot de planning. Zoals bij de behandeling van het milieu- en sportbeleid (1) ter sprake zal komen, worden heel wat gronden verworven om ze te vrijwaren met het oog op de passieve rekreatie of ze te valoriseren voor sportvoorzieningen.

Meer specifiek voor grondbeleid is een krediet van 4 miljoen F ingeschreven in de begroting voor 1974 (op te nemen leningen). Het gaat om een reserve waaruit het bestuur kan putten om terreinen te verwerven in het kader van de ruimtelijke planning. Er wordt niet gespecifieerd welk de bestemming kan of moet zijn van deze gronden, maar het gaat in elk geval niet om het systematisch aanleggen van een grondreserve voor woningbouw.

Men kan dus bezwaarlijk spreken van een grondbeleid in de strikte betekenis van het woord. Veeleer ligt de nadruk op de ruimtelijke ordening, waarbij het bestuur zich wapent om gronden voor de gemeenschap te verwerven, telkens een gunstige gelegenheid zich voordoet.

\subsection{WOONBELEID}

Herent deelt in de expansie van de Leuvense agglomeratie. Dit geldt speciaal voor de woonfunktie. Er is dan ook een belangrijke vraag naar diverse kategorieën van woongelegenheden.

\subsubsection{Sociale woningbouw}

Het overgrote aandeel in deze sektor heeft de bouwmaatschappij 'Volkswoningbouw te Herent'. De aktieradius van deze matschappij is tamelijk breed. Ze is $\mathrm{nl}$. aktief in Herent, Veltem-Beisem, Winksele en Tildonk, maar ook in Haacht en Baal. In tegenstelling tot de Leuvense 'Gewestelijke Samenwerkende Maatschappij voor de Huisvesting' die terloops ook in Herent optreedt, is 'Volkswoningbouw' naar de stadsrand gericht en naar het achterliggende gebied, met een hoofdaksent nochtans op Herent. Het schepenkollege is dan ook nauw betrokken bij de besluitvorming en 
situeert de sociale bouwinspanning in het geheel van haar woonbeleid. Volgende projekten werden sinds 1967 afgewerkt :

1. Borneveld : 80 woningen

2. Den Elst : 44 woningen

3. Wijveld : 100 woningen

In uitvoering is het projekt :

4. Keiberg : 104 woningen

terwij1 een vijfde projekt op stapel staat :

5. 's-Herenwegveld : 320 woongelegenheden, ten dele in hoogbouw.

De Gewestelijke Bouwmaatschappij uit Leuven was van haar kant betrokken bij de bouw van 16 huisjes voor bejaarden, de 'Rozengaard' te Wijgmaal.

Opvallend in deze sektor is vooral het aanzienlijk toegenomen bouwvolume in de meest recente projekten, de verschuiving naar de (meer verstedelijkte ?) hoogbouw toe en de hogere eisen t.a.v. de kwaliteit van het woonmilieu. Met name de groenomkadering van de bouwprojekten krijgt steeds meer aandacht.

\subsubsection{Privé woningbouw}

De grootscheepse privé-verkavelingen blijken daarentegen tot het verleden te behoren. Tijdens vorig mandaat werd nog een vergunning toegestaan voor het projekt 'Goddelinden-Hoogbeemd' met 90 percelen voor villabouw, maar zulke extensieve terreinbezetting kan nog moeilijk verantwoord worden. Toch blijft ook de privé-bouwinspanning nog aanzienlijk (een negentigtal bouwvergunningen per jaar), hetgeen de bevolkingsaangroei positief beînvloedt.

\subsubsection{Sanering}

De ongezonde- en krotwoningen 1iggen in Herent niet gegroepeerd. Het probleem is beperkt en geindividualiseerd. Toch wil het bestuur ingrijpen en heeft een krediet van 1 miljoen $F$. ingeschreven op de begroting 1974. Het bedrag is bescheiden, maar zal toch toelaten effektief tot sloping of sanering over te gaan in enkele gevallen.

Uit de bespreking van het milieu- en sportbeleid zal blijken dat Herent de sterke bouwinspanning gepaard wil laten gaan met een verhoogde aandacht voor kwaliteitsvoorzieningen in het onmiddellijk woonmilieu : 
groenaanleg, sport- en speelpleinen, zones voor passieve rekreatie. Het woonbeleid verwijst aldus naar de socio-kulturele beleidssfeer.

2. Socio-kulturee1, milieu- en welzijnsbeleid

\section{1. MILIEUBELEID}

\subsubsection{Milieuhinder}

Inzake de bestrijding van de milieuhinder heeft Herent op nationaal vlak de aandacht getrokken, door als eerste gemeentebestuur de sluiting van een bəlangrijk bedrijf te bekomen. Het betreft het aluminium-verwerkend bedrijf 'Coral Métal', sinds enkele jaren gevestigd aan de Spoorwegstraat, in het hart zelf van de gemeente. De milieubezwaren vanwege de omwonenden zijn echter al vee1 ouder. Ook op de vroegere inplantingsplaats was het bedrijf hinderlijk en kwamen er klachten. Toch werd een nieuwe vestiging in de bebouwde zone toegestaan. Onder de invloed van een toegenomen milieubewustzijn en de bundeling van het protest kon ditmal de sluiting verkregen worden vanwege de bestendige deputatie en het ministerie van arbeid. Het valt af te wachten of het bedrijf maatregelen zal nemen om de milieuhinder weg te werken en een nieuwe koncessie zal aanvragen. Belangrijk is in elk geval het sukses van de gekoncerteerde aktie van gemeentebestuur en aktiegroepen om de leefbaarheid van Herent te vrijwaren.

\subsubsection{Industriële inplanting}

Een vooruitziend milieubeleid kan zich niet beperken tot het sluiten van hinderlijke bedrijven. De huidige en toekomstige inplantingen moeten kritisch bekeken worden. In het ene geval zal men de industriële vestigingen afzonderen op daartoe gereserveerde terreinen of ze toch minstens omgeven met een groengordel, in het andere geval moet men aan een verwijdering denken uit de dichtbewoonde zone.

Beide situaties doen zich te Herent voor. Naast 'Coral Métal', eveneens aan de Spoorweglaan dus, ligt het belangrijk bedrijf 'Umafo'. In het 
kader van het gewestplan, het richtingsplan en het ontworpen B.P.A. 'Molenveld' wordt het gebied tussen Spoorweglaan en Rijweg als woonzone aangeduid. Deze besteming is $0 . \mathrm{m}$. aangewezen omwille van de gunstige ligging aan het spoorwegstation. Over de rol van het gemeentebestuur bij de sluiting van Coral Métal werd reeds gesproken. T.a.v. Umafo streeft men een minnelijke schikking na, hetgeen tot de mogelijkheden behoort omdat het bedrijf erg verouderd is en nog weinig toekomstperspektieven heeft. Indien deze beleidsoptie inderdaad gerealiseerd kan worden, dan betekent ze een bescheiden doorbraak voor de prioriteit van de woonomgeving t.a.v. onverantwoord ingeplante industrie.

De verwijdering van bedrijven uit de woonzone b1ijft uiteraard een uitzonderingsmatregel. Zelfs het isoleren van het bedrijf door het opleggen van een groengordel of bufferzone wordt nog maar zelden toegepast. Toch kreeg bv. de mouterij 'Dreyfus', aan de vaart gelegen, n.a.v. een aanvraag tot uitbreiding, een flink, groenscherm $(15 \mathrm{~m}$. dik) voorgeschreven. Gelijkaardige maatregelen worden overwogen telkens aanvragen tot verbouwing, uitbreiding of nieuwe exploitatie worden ingediend. In deze omstandigheden staat het gemeentebestuur sterk, is ze eisende partij. Dit geldt ook t.a.v. het lozen van afvalwaters. Alle Herentse bedrijven werden eraan herinnerd dat hiertoe vergunningen nodig zijn. Wanneer deze vergunningen dan aangevraagd worden, kunnen strenge eisen gesteld worden. Nu de vaart Leuven-Mechelen door het Rijk is overgenomen, houden de diensten van het Schelde-bekken toezicht op de waterverontreiniging en werken aldus ondersteunend voor het gemeentelijk milieubeleid. Naar de toekomst toe wil Herent de industriële vestigingen aan de vaart afremmen. In deze woongemeente bestaat veeleer behoefte aan ambachtelijke bedrijven, maar dan gekoncentreerd langsheen de rijksweg Leuven-Brussel en in de ambachtelijke zone voorzien aan de Tildonksesteenweg.

\subsubsection{Aanleg van groenzones}

Groene bufferzones kunnen wel de schadelijke invloeden van de industrievestigingen beperken, maar zijn niet bestemd voor de aktieve en passieve rekreatie van de bevolking. Sinds 1973 tekent zich hier een duidelijke beleidsoptie af. Herent wil de bestaande groenzones vrijwaren en openstellen voor het publiek. Naast de gronden die als sport- en/of spee1- 
terrein werden verworven en uitgerust (1), zijn het vooral een drietal parken die hier ter sprake moeten komen.

Aan de Mollekensstraat (deelgemeente Herent, B.P.A. Molendveldberg) werd een terrein van 1,5 ha aangekocht. Deze zone staat als parkgebied aangegeven en is vooral bedoeld voor passieve rekreatie. Dit park kan later uitgebreid worden.

Aan de Rijweg (deelgemeente Herent) werd een park aangelegd waarin tevens een speelplein is ingebouwd.

Het meest opmerkelijk projekt is echter ongetwijfeld het Rietenspark $(1,5 \mathrm{ha})$, in het volle centrum van Wijgmaal. Alleen reeds voor de aanleg van dit park wordt voor meer dan 5 miljoen $F$ geinvesteerd.

In de begroting voor 1974 staan bij de nog op te nemen leningen belangrijke investeringen vermeld die tot het groen- en milieubeleid in de brede betekenis gerekend kunnen worden, met name 4,5 miljoen F. voor de aankoop van gronden en 8 miljoen $F$. voor de aanleg van parken en plantsoenen. Van deze 8 miljoen gaat - zoals gezegd - het grootste aandeel naar het Rietenspark. Wat het verder verwerven van groenzones betreft, denkt men vooral aan het natuur- en parkgebied van de Dijle-vallei dat dicht bij de woonkern van Wijgmaal gelegen is.

$B i j$ de uitgaven in de gewone dienst vallen vooral de personeelskosten op. Men heeft additionele mankracht moeten aantrekken voor de aanleg en het onderhoud van parken en plantsoenen. Ook de werkingskosten en de schuld stijgen uiteraard, maar enige vergelijking met de voorgaande jaren is weinig relevant omdat men daar met een quasi nulpunt gekonfronteerd wordt. In absolute cijfers is de inspanning in elk geval drastisch gestegen. Tegenover $3 \mathrm{~F} /$ inwoner in 1971 voorzag men $130 \mathrm{~F}$ in 1973 en $295 \mathrm{~F}$ in 1974. Aan het milieubeleid - in onze omschrijving wordt $5,28 \%$ van de totale netto-uitgaven van de gemeente besteed.

Globaal zou men kunnen stellen dat Herent sinds een paar jaar een aktief milieubeleid is gaan voeren. Een maximale ontplooiing van de lokale industrie wordt als latente doelstelling verdrongen door een verantwoorde inplanting. Anderzijds krijgen de groenzones de volle aandacht : men wil ze niet alleen vrijwaren, maar vooral valoriseren naar het grote pu-

(1) Zie verder onder sport- en jeugdbeleid : 2.2. en 2.4. 
bliek toe. Dit zal nog meer blijken uit volgende paragraaf.

\subsection{SPORTBELEID}

De twee-kernenstruktuur van de gemeente komt zeer duidelijk tot haar recht in deze beleidssfeer. Sinds 1964 is er een sportcentrum gepland aan de Vloerstraat (Wijgmaalse steenweg), eerder aanleunend bij het kerkdorp Herent. Dit ambitieuze projekt dat o.m. een voetbalve1d, een atletiekpiste en een sportzaal voorziet, werd door het huidige bestuur (voorlopig ?) in de kartons geborgen. Het gewestplan voorziet voor deze terreinen nog steeds een sportief-rekreatieve bestemming, maar deze optie zal waarschijnlijk slechts op lange termijn gerealiseerd worden. Tegenover de 'eenheidsvisie' op de gemeente en de poging de voorzieningen te situeren op een centrale plaats, staat immers de beleidsoptie van dit bestuur elk van beide kernen te voorzien van een volwaardige sportinfrastruktuur en de elementaire voorzieningen zelfs te spreiden over de verschillende wijken.

$\mathrm{Na}$ een periode zonder investeringsuitgaven in deze sektor, vallen de initiatieven sinds 1971 des te sterker op. Wij sommen ze op per dee1gemeente. In Herent is het instruktiezwembad de grote blikvanger $(6,3$ miljoen $F$. reeds geĩnvesteerd, nog 1,740 miljoen $F$. voorzien op begroting 1974). In volle centrum gelegen (Schoolstraat), moet het in samenhang gezien worden met het reeds bestaande gemeentepark en de geplande sporthal. Het gemeentepark biedt de klassieke $o_{\mathbf{r}^{\prime}}$ enlucht-sportinfrastruktuur, terwij1 de polyvalente hal naast de zaalsporten ook ruimte wil bieden an alle mogelijke vormen van massa-manifestaties in de socio-kulturele sfeer. Het voetbalterrein an de Mechelse steenweg tenslotte wordt verder uitgebouwd en uitgebreid ( 2 miljoen F.). Voor het geheel van de sportinfrastruktuur over de gemeente (exklusief het zwembad) is ten andere een bedrag van $30 \mathrm{miljoen} \mathrm{F}$. voorzien. Op de begroting 1974 staat reeds 19 miljoen F. ingeschreven onder de vorm van nog op te nemen leningen, de overige $11 \mathrm{miljoen}$ zijn toegezegd van rijkswege.

Een belangrijk deel ( ${ }^{ \pm} 20$ miljoen F.) van deze toch aanzienlijke som is bestemd voor de uitbouw van een groot projekt in Wijgmaal. Oorspronke- 
1ijk behorend tot het Remy-patrimonium, werd het Ymeria-domein aangekocht voor 2,6 miljoen F., maar moet nu volledig vernieuwd en uitgerust worden. Dit $51 / 2$ ha groot terrein, ten dele op het grondgebied van Wilsele gelegen en aansluitend bij het natuurgebied van de Dijle, omvat zowel een vijuer en een bos als twee voetbalvelden en een dringend om te bouwen turnzaal. In de planning van de uitbouw van dit domein tot een sport- en kultuurcentrum krijgt de sport-/feestzaal prioriteit, en zal nadien het terrein opengesteld worden voor aktieve en passieve rekreatie. Kleinere gebouwen kunnen na restauratie en ombouw gebruikt worden als jeugdlokalen, hobbyclubs en $\operatorname{dg} l$.

Indien men ook de aanleg van speelterreinen tot deze beleidssfeer in de brede betekenis rekent (1) dan kan men niet anders dan de inspanning van dit bestuur voor de uitbouw van een volwaardige en gedifferentieerde sportinfrastruktuur vaststellen. Sommige opties hebben reeds de faze van de realisatie bereikt, maar de volle omvang van dit beleid zal pas over enkele jaren zichtbaar worden.

De weerslag op de uitgaven in gewone dienst is vanzelfsprekend. In 1973, maar meer nog in 1974 stijgen de personeelskosten (zwembad) en vooral de schuld drastisch. Tegenover 1971 waarin $26 \mathrm{~F} /$ inwoner voor sport werd uitgegeven staan nu de ramingen voor 1973 (249 F) en 1974 (531 F). Deze laatste som vertegenwoordigt $9,5 \%$ van de totale netto uitgaven van de gemeente. Bij de op te nemen leningen tenslotte werd een bedrag van $3 \mathrm{miljoen} F$. ingeschreven als reserve voor verdere grondverwervingen in de sport- en rekreatieve sfeer. Enige vergelijking met de vroegere uitgaven in dit domein is dan ook irrelevant geworden : dit is gewoon de doorbraak van een nieuwe beleidsoptiek.

Even markant nochtans als het uitgavenprofiel is de beleidsbeslissing deze infrastruktuur en voorzieningen niet éenmalig te plannen op het niveau van de hele gemeente, mar ze te spreiden en aan te passen, op de mat van de beide deelgemeenten.

\subsection{KULTUURBELEID}

De kulturele beleidssfeer is momenteel nog erg traditioneel te noemen. De subsidies aan de talrijke verenigingen vormen nog steeds het hoofd- 
aandeel in het uitgavenpakket, ook al zijn de werkingskosten sterk gestegen. De overheid heeft tot hiertoe een duidelijk aanmoedigende rol gespeeld, zonder zelf belangrijke initiatieven te nemen inzake voorzieningen en infrastruktuur.

In dit beeld komt echter verandering, mede onder de impuls van de kultuurraad. In Wijgmaal bestond reeds een aktief kultureel comité. Ook te Herent werd een plaatselijk comité van het verenigingsleven gevormd, en beide comités monden uit in de gemeentelijke kultuurraad. De tweeledigheid van deze opstelling beantwoordt aan de feitelijke groepering van het socio-kulturele leven rond de twee kernen. Ook in deze beleidssfeer zal de overheid daarom de voorzieningen afstemen op de specifieke behoeften en verwachtingen in beide deelgemeenten.

In Wijgmaal kan men reeds beschikken over een feestzaal die tot het Remy-patrimonium behoort, maar door de gemeente gehuurd wordt. Anderzijds wordt in het polyvalent Ymeria-projekt (zie onder sportbeleid) ruimte en akkomodatie voorzien voor socio-kulturele aktiviteiten. In Herent daarentegen plant men een nieuw 'ontmoetingscentrum'. Dit projekt krijgt gestalte in permanente dialoog met de kultuurraad. Over de inplanting werd reeds beslist : Kerkplein en Schoolstraat, in het hart van het dorp. De vormgeving is daarentegen nog onduidelijk, zowel inhoudelijk als architektonisch. In deze beleidssfeer is een geleidelijke projektontwikkeling in samenspraak met de adviesraden echter als een pluspunt te beschouwen.

\subsection{JEUGDBELEID}

Van een specifiek jeugdbeleid kan men in Herent slechts de laatste twee jaar spreken, en dan gaat de aandacht nog tamelijk exklusief naar het aanleggen van speelpleinen over gans de gemeente. Deze optie moge bescheiden zijn wat de financiële investering betreft (375.000 F. voor het speelplein aan de Rijweg, 600.000 F. aan nog op te nemen leningen voorzien), het gegroeide inzicht dat een leefbare woongemeente dringend behoefte heeft aan een aantal van deze voorzieningen is des te belangrijker naar de toekomst toe. In samenwerking met het privé-initiatief kunnen immers ook sport- en speelruimten gevaloriseerd worden waarvan de 
overheid de huursom opbrengt. Het is de bedoeling de speelruimte als een vanzelfsprekende komponent te gaan beschouwen van de woonomgeving. Naast de traditionele steun aan de jeugdverenigingen - inklusief forse toelagen voor het oprichten of verbouwen van jeugdlokalen - lijkt een konsekwente houding in deze een eerste aanzet van een meer aktief overheidsbeleid. Een gemeentelijke jeugdraad wordt momenteel opgericht.

\subsection{WELZIJNSZORG}

In tegenstelling tot de trend die in vorige paragrafen naar voor kwam, is er in deze sektor weinig innovatie te bespeuren. De behandeling van de individuele probleemgevallen wordt aan de matschappelijk assistente van de C.0.0. overgelaten. Geen gemeentelijke sociale dienst dus, en al evenmin een gemeentelijk initiatief inzake gezins- en bejaardenhulp. De belanghebbenden worden verwezen naar het prive-initiatief, dat dan echter gesubsidieerd wordt. Kinderdagverblijf en peutertuin blijven voorlopig toekomstplannen. In de begroting voor 1974 is een bedrag van 4 miljoen F. ingeschreven (op te nemen leningen) voor de bouw van sociale woningen voor bejaarden, maar deze vermelding blijkt niet te beantwoorden aan een beleidsoptie in de nabije toekomst. Kortom, Herent legt de prioriteiten voorlopig elders.

Men kan zich echter wel afvragen of deze feitelijke situatie het gevolg is van een weloverwogen keuze. Het ontbreken van een gezinsraad zou eerder kunnen wijzen op een beleidsvakuum. De bejaardenbonden van hun kant werden wel gemeentelijk gegroepeerd in de 'ouderenraad'.

3. Sociaal-ekonomisch en infrastruktuurbeleid

\subsection{INFRASTRUKTUURWERKEN}

In dit onderzoek naar de doeleindenstruktuur is een detail-bespreking van de uitgaven voor verkeer, wegen en waterlopen minder relevant. Het 
relatief gewicht van deze beleidssektor kan echter wel indikaties opleveren i.v.m. de prioriteiten die gedurende een bepaald beheersmandaat aangehouden worden. Dit geldt speciaal voor de investeringsuitgaven. Zoals uit het overzicht blijkt (1), werden tussen 1959 en 1964 voor V.W.W. zeer zware inspanningen gedaan die $76 \%$ van alle investeringen uitmaakten. Het daarop volgende kollege heeft duidelijk de riem aangehaald, en dit over de ganse lijn, want het relatief aandeel van V.W.W. is niet drastisch gedaald. Het huidig kollege investeert weer meer en heeft nog een heel programma op het getouw staan, maar het relatief gewicht van V.W.W. is bijna met de helft gedaald t.o.v. de periode 1959-1964. 55 \% van alle investeringen kunnen nu buiten de traditionele V.W.W.-sektor gebeuren. Ook in de gewone dienst is een relatieve afname te noteren ondanks de sterk gestegen absolute uitgaven. Voor het begrotingsjaar 1974 wordt nog $40 \%$ der uitgaven aan V.W.W. besteed.

\subsection{OPTIES}

Aan een specifiek gemeentelijk sociaal-ekonomisch beleid in de zin van een systematisch aantrekken van bedrijven of het kreëren van werkgelegenheid bestaat er momenteel in Herent geen behoefte. De overheidstaak is eerder gericht op een verantwoorde inplanting en het reduceren van de milieuhinder (Tildonksesteenweg). Het B.P.A. nr 4 wil aldus aan ambachtelijke bedrijven een aantrekkelijke inplanting aanbieden en op deze wijze een diversifikatie van de werkgelegenheid ter plaatse bevorderen. De ekonomische dynamiek van de Leuvense agglomeratie kan deze eerder regelende dan stimulerende houding van het gemeentebestuur wel verklaren.

Wat de verkeersproblematiek betreft is de andacht minder agglomeratiegericht dan lokal gebonden. De toegang tot Leuven stelt wel tal van problemen, maar de nieuwe invalsweg ervaart men als een Leuvense aangelegenheid. Ook het tracé van de autowegen en de zgn. Westelijke tangente staat niet centraal in de aandacht. Wellicht beseft men dat het impakt van het gemeentelijk standpunt op de besluitvorming terzake niet zo sterk is, en dat hoe dan ook de gemeente niet wezenlijk aangetast wordt door de geplande wegen.

(1) Cfr. bijlage $3 \mathrm{D}$ 
Veel duidelijker is de hinder van vaart en spoorweg voor de verkeersontsluiting van Wijgmaal. In het B.P.A. voor Wijgmaa1-Centrum is dan ook een plan opgenomen voor de reorganisatie van het verkeer en de verkeersinfrastruktuur.

4. Interne bestuursorganisatie

\subsection{PERSONEELSKADER}

De dynamiek van het huidige kollege heeft met name in de socio-kulturele beleidssfeer een aantal perspektieven geopend die ongetwijfeld reperkussies zullen hebben op de struktuur en de kwaliteit van het personeelskader. Vooralsnog is deze weerslag echter amper vast te stellen. De voogdijoverheid, vooral dan het Ministerie van Binnenlandse Zaken, moet in casu nog overtuigd worden van de noodzaak van een personeelsuitbreiding en -differentiatie op andere dan bevolkingscriteria. Het opsplitsen van het personeel naar specifieke taken in de socio-kulturele sfeer is hier dan ook (nog) niet mogelijk. Wel worden er pogingen ondernomen om werkploegen te vormen die eerder afgestemd zijn op groenaanleg of wegenonderhoud.

Personee1skader

Algemene administratie 10 f.t. 2 p.t. Justitie - Politie $6 \mathrm{f} . t$.

Technisch personee1 10 f.t. 2 p.t.

Volledigheidshalve moeten hier 5 tijdelijk tewerkgestelden bijgerekend worden die de permanentie in het instruktiezwembad waarnemen.

Aangezien het hele kader aan een grondige herziening toe is, 1ijkt het weinig relevant de funkties verder te specificeren, behalve dan wat het 'kaderpersonee1' betreft. 


\subsection{KOLLEGE VERSUS ADMINISTRATIE}

In de Herentse kontekst is nu juist dit 'kader' een pijnlijk vacuum in de poging van het kollege aan systematische beleidsvoorbereiding en -uitvoering te doen. Zonder personalia ter sprake te willen brengen kan men toch stellen dat dit kader (sekretaris, ontvanger, onderbureauchef, verantwoordelijke technische dienst) niet opgewassen is voor beleidstaken. Het is ten andere niet op basis van deze kompetenties dat het huidige personee 1 aangetrokken is. Niettemin vormt deze personeelsbezetting een zware hypotheek op de dynamische verwerkelijking van de opties die in raad en kollege genomen werden. De schepenen zijn dan ook geneigd de persoonlijke leiding op zich te nemen van de uitvoeringstaken in de hun toevertrouwde sektor.

5. Bespreking van het uitgavenpatroon

Wanneer men de uitgaven per begrotingsfunktie schikt en bv. de $5 \%$-grens aanhoudt om de belangrijke sektoren in reliëf te brengen, komen duidelijk een zevental funkties naar voor :

\begin{tabular}{l|c|c|c|c}
\hline $\begin{array}{l}\text { Begroting voor 1974 } \\
\text { Funkties }\end{array}$ & $\begin{array}{l}\text { Uitgaven per } \\
\text { inwoner }\end{array}$ & $\begin{array}{l}\text { In \% van het } \\
\text { totaal }\end{array}$ & $\begin{array}{l}\text { Netto-uitgaven } \\
\text { per inwoner }\end{array}$ & $\begin{array}{c}\text { In \% van } \\
\text { het totaal }\end{array}$ \\
\hline $\begin{array}{l}\text { Algemene } \\
\text { administratie }\end{array}$ & 679 & 10,19 & 670 & 11,97 \\
Justitie-Politie & 379 & 5,69 & 379 & 6,77 \\
Verkeer-Wegen-Waterlopen & 2425 & 36,40 & 2152 & 38,42 \\
Volksontwikkeling en & 1199 & 18,00 & 1005 & 17,95 \\
Kunst & 322 & 4,84 & 322 & 5,76 \\
Sociale voorzorg en & & 4,50 & 291 & 5,20 \\
onderstand & 300 & 4,10 & 272 & 4,87 \\
Ontsmetting-Reiniging- & 272 & 83,72 & & 90,94 \\
Huisvuil & & & \\
Afvalwater & - & & \\
\end{tabular}


De netto-uitgaven zijn uiteraard de meest beleids-indikatieve. Daarom werd de $5 \%$-grens berekend op deze uitgaven, met een kleine toegeving aan de funktie 'afvalwater'. Geen enkele van de andere funkties bereikt nog de $4 \%$ en een te rigoureuse toepassing van de willekeurige $5 \%-1 i-$ miet zou het uitgavenbeeld vertekenen. Dit zou nog meer gelden moesten we ons baseren op de bruto-uitgaven. Aan kleuter- en lager onderwijs bv. besteedt Herent 5,38\% van de totale bruto-uitgaven, maar slechts $3,25 \%$ netto. Onderwijs krijgt dan ook slechts een secundaire plaats toebedeeld in het uitgavenprofiel.

Verkeer-Wegen en Waterlopen (V.W.W.) neemt traditioneel de ereplaats in met $38,5 \%$ van de totale netto-uitgaven, maar dit aandeel is zoals hoger reeds aangetoond sub $3^{\circ}$ - de jongste jaren sterk achteruitgelopen. In de rekening over 1971 bedroeg dit nagenoeg $46 \%$. Volksontwikkeling en Kunst gaat daarentegen pijlsnel de hoogte in : van 2,79 in 1971 tot nagenoeg $18 \%$. Hier ligt duidelijk een 'pointe' in de beleidsprioriteiten, zoals blijkt uit de bespreking van de hele socio-kulturele beleidssfeer. In het licht van deze bruuske en scherpe ontwikkeling kan het relatieve aandeel van de andere meer traditionele funkties alleen maar ter plaatse fluktueren of lichtjes dalen, en dit ondanks soms forse stijgingen in de absolute uitgaven. Omwille van het onderscheid tussen rekeningen (1971-72) en begrotingen (1973-74) zijn deze uitgaven echter moeilijk te evalueren en blijft het relatieve aandeel van de funktie in het geheel nog de beste indicator.

Ook de meer bescheiden funkties die vooralsnog ver onder de $5 \%$-grens liggen kunnen beleidsrelevante trends aanduiden. Zo bv. de funktie 'Huisvesting en stedebouw' waarvan het aandeel sinds 1971 (1,24\%) meer dan verdubbeld is $(2,83 \%)$.

Een globale vergelijking van de twee begrotingsjaren (73 en 74) wat de personeelsuitgaven, de werkingskosten, de overdrachten en de schuld betreft, toont vooral het stijgend aandeel van de schuld aan. De investeringsuitgaven worden dus geleidelijk belangrijker en het is de funktie Volksontwikkeling en Kunst die deze verschuiving heeft bewerkstelligd. 


\begin{tabular}{l|l|c|c|c}
\hline Begrotingsjaar & $\begin{array}{l}\text { Personeels } \\
\text { uitgaven }\end{array}$ & $\begin{array}{l}\text { Werkings- } \\
\text { kosten }\end{array}$ & Overdrachten & Schuld \\
\hline 1973 & 29,32 & 25,81 & 7,87 & 37,00 \\
1974 & $\frac{27,73}{1,59}$ & $\underline{-1,87}$ & $+\frac{8,28}{0,41}$ & $\frac{40,05}{+3,05}$ \\
\multirow{2}{*}{ Trend } & $-1,94$ & + \\
\hline
\end{tabular}

\section{Elementen van synthese (1)}

Indien beeldrijke taal toegelaten is bij een poging de meest relevante elementen uit de beleidsbespreking naar voor te halen, zou men kunnen stellen dat Herent als het ware uit een winterslaap ontwaakt is. Tijdens het beheersmandaat 1965-70 werd inderdaad een noodzakelijke soberheidspolitiek (omwille van de hoge schuldenlast) vereenzelvigd met een beleidsvacuum. Zelfs aan financieel weinig-konsekwente projekten was men kennelijk niet toe. Het huidig bestuur heeft in dit vlakke landschap een duidelijk reliëf gebracht. Ruimtelijke ordening, milieuzorg en sportbeleid zijn vooralsnog de meest opvallende zwaartepunten, maar ook inzake kultuur- en jeugdbeleid zullen de realisaties binnen afzienbare tijd tot hun recht komen.

Het heeft weinig zin in elk van deze beleidssferen nogmaals de aksenten te onderlijnen. Alleen inzake ruimtelijke ordening zouden we een fundamentele optie willen aanstippen die impliciet bepalend is voor nagenoeg de hele socio-kulturele beleidssfeer. Zoals reeds werd angetoond (2) speelt het huidig kollege veel sterker dan vroeger in op de sociaal-ruimtelijke realiteit, en met name op de tweeledige struktuur van de gemeente. Er wordt rigoureus gewaakt over een evenwichtige spreiding van voorzieningen en diensten, en waar dit evenwicht in het gedrang komt door een éênmalige inplanting als de bouw van het zwembad, kan men in het Ymeria-komplex een 'kompensatie' zien. Het gaat hier evident niet om

(1) Cfr. de uitwerking van deze synthese in het doeleindenschema (separate opbergmap).

(2) Cfr. sportbeleid : 2.2. 
een afwegen op een gouden schaaltje. Veel belangrijker is het de voorzieningen aan te passen aan de specifieke behoeften van de deelgemeenten, ze als het ware 'op mat te snijden'. Een woonkern in een industriële omgeving - als Wijgmaal - heeft op een andere wijze behoefte aan een rekreatiegebied in de onmiddellijke omgeving dan een evenwichtig gegroeid semi-landelijk hoofddorp.

Toch mag deze basisoptie van het bestuur niet geinterpreteerd worden als het opgeven van een eenheidsvisie op de gemeente. Veeleer kan men denken aan een 'gefedereerde' opstelling van de deelgemeenten. De werking van de kultuurraad bv. is reeds enigszins op dit model afgestemd. Mettertijd zijn 'supra-deelgemeentelijke' voorzieningen beslist denkbaar, zo bv. het centraal gelegen sportkomplex. Momenteel gaat de prioriteit echter naar de basisvoorzieningen in elk der kerkdorpen.

Niet in alle beleidssferen is éénzelfde dynamiek te onderkennen. Domeinen (a1s de gezinsproblemen) en aspekten (a1s de inspraak) waarover verschillende opvattingen bestaan bij de koalitiepartners, komen ook minder aan bod. De persoonlijke visie en dynamiek van de betrokken schepenen spelen hier uiteraard in mee. Zoals het wel meer voorkomt in een koalitie, bekleedt de burgemeester ook hier niet een monopoliepositie t.a.v. de politieke besluitvorming. Het is gezond voor de gemeentelijke instelling wanneer elk der schepenen een eigen bijdrage levert, mits - zoals in Herent - de kohesie gevrijwaard blijft.

Tot slot zou men de sterk gemotiveerde wil van alle beleidsverantwoordelijken kunnen aanhalen om Herent een 'eigen gelaat' te laten bewaren. Een ongedifferentieerd opgaan in de stedelijke agglomeratie wordt radikaal afgewezen. In positieve zin ontwikkelt Herent sinds een paar jaar een alternatief in de zin van een bestuurskrachtige gemeente met een veelzijdig voorzieningenaanbod.

\subsection{VERGELIJKENDE STUDIE VAN HET UITGAVENPROFIEL IN LEUVEN, KESSEL-LO EN HERENT}

De extra-1asten die een centrum-stad te dragen heeft moeten vooral blijken uit de uitgaven voor funkties met een uitgesproken regionale dimensie. In deze beperkte analyse zouden we de besteding per inwoner in de 
centrum-stad willen toetsen aan de vergelijkbare uitgaven in de twee weerhouden randgemeenten. Deze vergelijking mag niet tot overij1de en overtrokken konklusies leiden, omdat elke gemeente een eigen sociaalruimtelijk gelaat heeft en een oorspronkelijke sociaal-ekonomische werkelijkheid is met specifieke kentrekken die het uitgavenpatroon kunnen beinvloeden. Dit geldt allereerst voor de centrum-stad, die behalve centrum van het stadsgewest en de regio ook nog stad is, met heel de verdichting van problemen en opdrachten die dit inhoudt. Kan dus - zeker in deze kontekst - geen absoluut geldende vergelijking opgemaakt worden, dan zal wellicht toch de feitelijke taakperceptie en -vervuliing in stad en rand in relatieve termen gepreciseerd kunnen worden.

Liever dan er een momentopname van te maken, zouden we in deze analyse de soms vrij sterke evolutie willen verrekenen die bepaalde funkties op zeer korte termijn doormaken, hetgeen de onderlinge verhouding der funkties kan beïnvloeden. Om de huidige stand van zaken zo getrouw mogelijk te benaderen konden we niet anders dan beroep doen op de begrotingsgegevens voor 1974. Deze niet zo sekure cijfers geven bij de vergelijking met de meest recent goedgekeurde rekening, deze nl. over het dienstjaar 1972, een 'gap' die des te bedrieglijker is vanwege de snelle inflatie. De bestedingscijfers per inwoner worden daarom vergezeld door het aandeel van de funktie in kwestie in het geheel van de uitgaven in 1972 en 1974.

Uit de rekening en begroting zouden we eerst enkele funkties willen releveren waarvan de 'agglomeratie-gevoeligheid' zonder meer - zij het in verschillende intensiteit - voor de hand ligt. Een funktie als algemene administratie b.v. 1ijkt op het eerste zicht uitgesproken lokaa1beperkt te zijn. In feite behartigt de centrum-stad echter vele formaliteiten en dossiers : burgerlijke stand (ziekenhuizen), vreemdelingenpolitie (koncentratie in de binnenstad), sociale aanvragen (minderbegoeden), enz. De funktie Justitie-Politie omvat nog duidelijker supra-1okale elementen, al was het maar omwille van de verkeerspolitie die het verkeer van en naar de rand in goede banen moet leiden. De brandbestrijding is minder geschikt als vergelijkingsmaterie omdat niet enkel de organisatie maar ook de bijdrage van de participerende gemeenten door nationale richtlijnen beheerst worden. Toch leek het ons boeiend die feitelijke bijdragen eens naast elkaar te plaatsen, wel wetende dat een 
stad andere brandrisico's loopt dan de randgemeenten. De belangrijke funktie 'verkeer, wegen, waterlopen' reikt in sommige gemeenten niet uit boven de eigen grenzen. Toch kunnen op deze post ook fundamentele opties voorkomen zoals de verkeerstechnische renovatie van de binnenstad of de (her)aanleg van invalswegen : twee aangelegenheden die de hele agglomeratie aangaan. 'Volksontwikkeling en Kunst' is de noemer waaronder uiteenlopende taken als de aanleg van groenzones en de sporten kulturele infrastruktuur ressorteren : vanzelfsprekend dus realisaties met supra-lokale relevantie. Vooralsnog kan dit misschien niet zo meteen gezegd worden van de laatste geanalyseerde funktie : huisvesting en stedebouw. Vooral aspekten als stadsontwikkeling en stadskernvernieuwing hebben nochtans een regionale draagwijdte : de city is de ontmoetingsruimte voor elke agglomeratiebewoner en wordt op de mat van de agglomeratie afgestemd.

De verfijning die we in de socio-kulturele sfeer nagestreefd hebben moet ook hier tot haar recht komen. De funktie Volksontwikkeling en Kunst zal daarom opgesplitst worden volgens de uitzichten milieubeleid, sportbeleid, kultuurbeleid en jeugdbeleid.

De gegevens voor deze analyse worden uitsluitend geput uit de gewone dienst. Doordat de jaarlijkse aflossing van de schuld hierin verwerkt zit, is de analyse niet ongevoelig voor de investeringsuitgaven. De precieze draagwijdte van deze investeringen moet natuurlijk per gemeente uit de overzichtstabellen in absolute cijfers afgeleid worden. Tenslotte leek het ons relevant ook het relatieve aandeel van personeelsuitgaven, werkingskosten, overdrachten en schuld in de onderzochte gemeenten na te gaan. Al zijn deze totaalcijfers zeer algemeen, toch kunnen ze iets zeggen over de al dan niet toegenomen marge die openblijft voor be leidsuitgaven. 
Tabel I. OVERZICHT VAN DE UITGAVEN PER FUNKTIE MET REGIONALE DIMENSIE
- Gewone dienst

- Aangezuiverde uitgaven

\begin{tabular}{|c|c|c|c|c|c|c|c|c|c|c|c|c|}
\hline \multirow[b]{3}{*}{ Funktie } & \multicolumn{4}{|c|}{ LEUVEN } & \multicolumn{4}{|c|}{ KESSEL-LO } & \multicolumn{4}{|c|}{ HERENT } \\
\hline & \multicolumn{2}{|c|}{ Rekening ' 72} & \multicolumn{2}{|c|}{ Begroting 174} & \multicolumn{2}{|c|}{ Rekening ' 72} & \multicolumn{2}{|c|}{ Begroting 14} & \multicolumn{2}{|c|}{ Rekening ' 72} & \multicolumn{2}{|c|}{ Begroting $\cdot 74$} \\
\hline & $\begin{array}{l}\text { per } \\
\text { inw. }\end{array}$ & $\%$ & $\begin{array}{l}\text { per } \\
\text { inw. }\end{array}$ & $\%$ & $\begin{array}{l}\text { per } \\
\text { inw. }\end{array}$ & $\%$ & $\begin{array}{l}\text { per } \\
\text { inw. }\end{array}$ & $\%$ & $\begin{array}{l}\text { per } \\
\text { inw. }\end{array}$ & $\%$ & $\begin{array}{l}\text { per } \\
\text { inw. }\end{array}$ & $\%$ \\
\hline Alg. administratie & 1264 & 17,27 & 1729 & 18,10 & 410 & 18,35 & 625 & 16,57 & 398 & 14,61 & 670 & 11,97 \\
\hline Justitie-Politie & 1235 & 16,88 & 1607 & 16,81 & 330 & 14,79 & 474 & 12,57 & 289 & 10,85 & 379 & 6,77 \\
\hline Brandweer & 440 & 6,02 & 627 & 6,57 & 42 & 1,89 & 54 & 1,45 & 44 & 1,68 & 47 & 0,84 \\
\hline $\begin{array}{l}\text { Verkeer-wegen- } \\
\text { waterlopen }\end{array}$ & 1472 & 20,11 & 1633 & 17.09 & 669 & 29,93 & 959 & 25,43 & 1203 & 45,10 & 2152 & 38,42 \\
\hline $\begin{array}{l}\text { Volksontwikkeling } \\
\text { en Kunst }\end{array}$ & 1031 & 14,09 & 1638 & 17,14 & 225 & 10,07 & 583 & 15,46 & 89 & 3,35 & 1005 & 17,95 \\
\hline $\begin{array}{l}\text { Huisvesting en } \\
\text { stedebouw } \\
\text {... }\end{array}$ & 62 & 0,85 & 164 & 1,72 & 40 & 1,79 & 83 & 2,21 & 28 & 1,07 & 158 & 2,83 \\
\hline TOTAAL & 7321 & 100 & 9558 & 100 & 2235 & 100 & 3773 & 100 & 2669 & 100 & 5602 & 100 \\
\hline
\end{tabular}


- Gewone dienst

- Aangezuiverde uitgaven

\begin{tabular}{|c|c|c|c|c|c|c|c|c|c|c|c|c|}
\hline \multirow{3}{*}{$\cdots$} & \multicolumn{4}{|c|}{ LEUVEN } & \multicolumn{4}{|c|}{ KESSEL-IO } & \multicolumn{4}{|c|}{ HERENT } \\
\hline & \multicolumn{2}{|c|}{ Rekening 72} & \multicolumn{2}{|c|}{ Begroting 174} & \multicolumn{2}{|c|}{ Rekening ' 72} & \multicolumn{2}{|c|}{ Begroting 174} & \multicolumn{2}{|c|}{ Rekening '72 } & \multicolumn{2}{|c|}{ Begroting ' 74} \\
\hline & $\begin{array}{l}\text { per } \\
\text { inw. }\end{array}$ & $\%$ & $\begin{array}{l}\text { per } \\
\text { inw. }\end{array}$ & $\%$ & $\begin{array}{l}\text { per } \\
\text { inw. }\end{array}$ & $\%$ & $\begin{array}{l}\text { per } \\
\text { inw. }\end{array}$ & $\%$ & $\begin{array}{l}\text { per } \\
\text { inw. }\end{array}$ & $\%$ & $\begin{array}{l}\text { per } \\
\text { inw. }\end{array}$ & $\%$ \\
\hline ilieubeleid & 385 & 5,27 & 509 & 5,33 & 92 & 4,12 & 240 & 6,36 & 30 & 1,13 & 295 & 5,28 \\
\hline Sportbeleid & 269 & 3,69 & 502 & 5,25 & 85 & 3,85 & 239 & 6,34 & 34 & 1,30 & 531 & 9,49 \\
\hline Wulturbeleid & 398 & 5,45 & 648 & 6,78 & 34 & 1,53 & 83 & 2,22 & 41 & 1,54 & 116 & 2,08 \\
\hline Teugảbeleid & 7 & 0,11 & 1839 & 0,19 & 8 & 0,37 & 40 & 1,08 & 7 & 0,27 & 52 & 0,93 \\
\hline
\end{tabular}




\begin{tabular}{l|c|c|c|c|c}
\hline & $\begin{array}{l}\text { Personee1s- } \\
\text { uitgaven }\end{array}$ & $\begin{array}{l}\text { Werkings- } \\
\text { kosten }\end{array}$ & $\begin{array}{l}\text { Over- } \\
\text { drachten }\end{array}$ & Schuld & $\begin{array}{l}\text { Interne ver- } \\
\text { richtingen }\end{array}$ \\
\hline Leuven & 59,26 & 11,71 & 6,00 & 22,19 & 0,84 \\
Kesse1-Lo & 36,80 & 13,12 & 11,54 & 38,54 & - \\
Herent & 27,73 & 23,94 & 8,28 & 40,05 & - \\
\hline
\end{tabular}

Reeds bij een eerste aanblik van tabel I valt het grote onderscheid op in de absolute besteding per inwoner tussen Leuven en de randgemeenten. Het procentueel aandeel van de funktie in het geheel van de uitgaven is heel wat gelijklopender en relevanter als indikatie voor de beleidsprioriteiten. Het meest in het oog springend is wel de 'explosie' van de funktie Volksontwikkeling en Kunst in Herent. Deze sprong vertekent ten andere het procentuee 1 aandee 1 van de andere funkties in de begrotingsuitgaven voor 1974. De afname van hun aandeel mag niet tot voorbarige konklusies leiden gezien de soms forse stijging in de absolute besteding.

Men mag dan ook zeggen dat het aandeel van de 'Algemene Administratie' procentsgewijze tamelijk gelijklopend is in de drie gemeenten. 'Justitie-Politie' neemt daarentegen in belang af naarmate de gemeente kleiner wordt. De funktie 'Brandweer' illustreert ten overvloede de overbelasting van de centrum-stad t.a.v. de rand, zelfs wanneer men rekening houdt met de hogere risico's. De funktie die in een traditionee 1 gemeentelijk uitgavenpatroon het meest doorweegt is wel 'Verkeer-wegenwaterlopen'. Opvallend is dan ook het hoge \% voor Herent, slechts op verre afstand gevolgd door Kessel-Lo. Dit aandeel wijst op het karakter van het voorheen gevoerde beleid te Herent. Zoals gezegd is de prioriteit er zich thans drastisch aan het verleggen in de richting van 'Volksontwikkeling en Kunst'. Minder spektakulair maar toch zeer opmerkelijk is ook de stijging in Kessel-Lo en Leuven. Deze funktie vormt blijkbaar de 'pointe' in het hedendaags beleid. Wij hebben ze daarom op een verfijnde wijze willen benaderen. Eerst dienen we echter nog aan te stippen dat 'Huisvesting en stedebouw' vooralsnog een zwakke figuur slaat in het uitgavenoverzicht. De toekomstplannen inzake urbanistische vernieuwing zijn grootser dan de uitgaven thans doen vermoeden. Het totaal voor alle uitgaven vestigt nogmals de aandacht op het markant 
verschil in de absolute besteding per inwoner in Leuven enerzijds, in de randgemeenten anderzijds. Indien we ons baseren op de meest betrouwbare cijfers, de rekening over $1972 \mathrm{n} 1$., dan geeft Kessel-Lo niet één derde uit en Herent iets meer dan één derde van wat Leuven per inwoner besteedt.

Uit tabel II, waarin we een typische welzijnstaak als de funktie 'Volksontwikkeling en Kunst' nader analyseren, blijkt een vergelijkbare zorg voor het milieu in Leuven en Kesse1-Lo. We weten echter uit de bespreking per gemeente dat de aard van de uitgaven in beide gemeenten verschillend ligt. Leuven geeft veel uit aan haar plantsoendienst, terwijl Kesse1-Lo vooral groenzones verwerft. Herent komt dank zij een paar forse investeringen in eeen jaar op hetzelfde peil.

Inzake sportbeleid zijn er weer markante verschillen in de absolute besteding. Hier maakt Herent een reuzesprong voorwaarts en overtreft (in begrotingsvooruitzichten) zelfs Leuven. Ook Kessel-Lo doet een inspanning en gaat in een tijdspanne van twee $j$ aar het percentage nagenoeg verdubbelen, terwijl ook te Leuven de absolute en relatieve besteding flink stijgt. Het sportbeleid verschijnt dan ook als de sektor waarin letterlijk en figuurlijk het sterkst geinvesteerd wordt.

Zoals te verwachten was ligt de groei in de sektor kultuurbeleid gans anders. Hier bouwt Leuven de bestaande infrastruktuur verder uit en heeft daarbij een zware personeelslast te dragen. Kessel-Lo geeft daarentegen als grootste randgemeente minder uit dan Herent. Hier stoten we op een der meest typische voorbeelden van de stad-rand problematiek. Inzake sportinfrastruktuur doen zowel Kesse1-Lo als Herent een opvallende inspanning. Dit is ongetwijfeld te verklaren vanuit de onvoldoende of moeilijk bereikbare akkomodatie in het centrum, maar wellicht al evenzeer vanuit de huidige prioriteiten bij de publieke opinie (en vandaar ook bij de beleidsvoerders). Terecht verwacht men van het bestuur optimale sportvoorzieningen in de onmiddellijke woonomgeving. Ten aanzien van de kulturele voorzieningen ligt dit vooralsnog blijkbaar anders. De randbewoners worden taciet verwezen naar de akkomodatie in de stad. De stad blijft aldus echter alleen staan met de investerings- en personeelslast.

De sektor jeugdbeleid verdient amper deze naam, omdat hij behoudens de 
aanleg van een paar speelpleinen en een initiatief te Kessel-Lo op geen feitelijke opties berust.

Uit tabel III blijkt tenslotte de loodzware personeelslast (nagenoeg $60 \%$ van alle uitgaven) die Leuven moet torsen. Een uitgebreid personeelskader kan een indikatie vormen voor een kwaliteitsservice aan de burgers, mar een dergelijke verhouding beperkt hoe dan ook de investeringsmogelijkheden. Herent en Kesse1-Lo besteden aan personee 1 zowat de helft van het Leuvense aandeel, en kunnen (in relatieve termen) dan ook nagenoeg het dubbel bestemmen voor investeringsuitgaven. Ook hieruit blijkt een fundamentele ongerijmdheid. De centrum-stad waarop de rand rekent voor een aantal voorzieningen beschikt over een aanzienlijk meer beperkte marge voor investeringen. Naast een netelige financiële situatie moet zulke toestand vooral het status-quo in de hand werken. Een talrijk personeelskader verzorgt de lopende zaken, maar er blijft weinig ruimte voor fundamentele innovaties waardoor de centrum-stad dynamisch zou kunnen inspelen op een nieuwe taakperceptie.

Mede op basis van deze financiële doorlichting, zal de doeleindenstruktuur van Leuven, Kesse1-Lo en Herent in een vergelijkend perspektief geanalyseerd worden in het kader van het algemeen besluit. 
ALGEMEEN BESLUIT

1. Op welke schaal moet de gemeente van de toekomst gestalte krijgen ? Weinig bestuursvragen zijn zo komplex gebleken, wellicht omdat de schaal-problematiek de wezenskentrekken zelf van de gemeentelijke instelling in vraag stelt. Het debat is hierdoor verruimd tot een vraag naar de gewenste maatschappelijke ontwikkeling, naar de zin en de kansen van de politieke demokratie op het levensnabije niveau. Het besef dat deze problematiek haar horizon en matstaven overstijgt, ontslaat de bestuurswetenschap nochtans niet van haar verantwoordelijkheid. Ze kan weliswaar niet het laatste woord spreken over de territoriale omschrijving en de inhoudelijke opvulling van het lokaal bestuur, maar ze heeft niettemin tot taak de termen van het probleem te verhelderen en hun onderlinge samenhang te preciseren.

Met dit proefschrift hebben we gepoogd deze taakstelling aan te vatten, met als aangrijpingspunten de twee sleutel-begrippen van de bestuur1ijke herstrukturering, te weten : de schaalvergroting en de bestuurskracht. De schaalvergroting is hierbij het onmiddellijk waarneembare element. De aandacht van de beleidsverantwoordelijken, okkasioneel zelfs van de publieke opinie, wordt er dan ook door gepolarizeerd, vaak zelfs gemonopoliseerd. Hierdoor verliest men echter het instrument-karakter van deze schaal-aanpassing uit het oog, ten overstaan van de 'bestuurskracht' als meest algemene omschrijving van de norm en de doelstelling van de herstrukturering. Een globale benadering van de problematiek dient dan ook het hele spanningsveld te omsluiten van middel en doel, van hervormingsmaatregel en (verhoopt) effekt.

De gekozen invalshoek is dubbel : begripsverhelderend en relatietoetsend. Het probleemverkennend deel biedt het initiale kader waarbinnen het toetsend onderzoek kan plaatsvinden. Het is echter evenzeer de bedoeling het begrippenapparat zelf aan te zuiveren en te operationa1 iseren vanuit de empirische vaststellingen. In dit algemeen besluit waarin we niet systematisch de bevindingen van het theoretisch deel willen hernemen, maar de sleutelbegrippen ter sprake brengen in funktie van de nieuwe belichting en dimensie die het empirisch onderzoek ople- 
verde, zullen we dan ook uitgaan van de specifieke resultaten van het evaluatie- en doeleindenonderzoek.

2. Het eerste luik van het toetsend onderzoek slaat vanzelfsprekend op de 10 jaar ervaring met gemeentelijke herstrukturering (1964-74). ook de focus van bevraging ligt voor de hand : de effekten van de herindelingsmaatregelen op korte termijn en de ontwikkelingen die hierdoor al dan niet op gang werden gebracht. De fusiegemeente Oudenaarde krijgt hierbij vanwege haar format, ruimtelijke kontekst (centrumstad - ommeland) en ervaringsduur een bijzonder reliëf. De onderzoeksgegevens uit deze case-study zullen echter gekonfronteera moecen woräen met de bevindingen uit de evaluatie-studies in Zuid-Limburg, Brabant en West-Vlaanderen, om tot een brede doorlichting te komen van de fusieproblematiek in Vlaanderen. Rond drie aandachtspunten zouden we de resultaten willen bundelen : de integratie van de deelgemeenten in de nieuwe entiteit, de reorganisatie van gemeentepersoneel en -diensten en de nieuwe beleidskoers.

2.1. De integratieproblematiek zal in een bestuurswetenschappelijke studie allereerst belicht worden vanuit de formele participatiekansen die de deelgemeenten krijgen in de fusiegemeentelijke besluitvormingsen bestuursorganen. In Oudenaarde valt het bilan vrij positief uit voor de vertegenwoordiging van de grotere deelgemeenten in raad en kollege. Er werd een evenwichtige verdeling der mandaten bereikt ondanks de aanvankelijk fusie-afwijzende houding van enkele randgemeenten. De kleinere deelgemeenten ( 4 van de 12 ) bereikten daarentegen niet het minimumpeil om voor een mandaat op basis van deze verdeelsleutel in aanmerking te komen. Deze niet-vertegenwoordiging blijkt nochtans uitzonderlijk te zijn (1) en is te verklaren door de disproportie tussen de deelgemeenten. De billijke spreiding der bestuursverantwoordelijkheden

(1) Slechts twee bijkomende gevallen werden in het geheel van ons onderzoeksgebied vastgesteld : Bost (Tienen) en Mettekoven (Heers). 
komt hierdoor als regel niet in het gedrang.

Opvallend is evenwel dat de herkomst der kandidaten bij het aantreden van een tweede ambtstermijn niet meer met dezelfde nauwgezetheid afgemeten wordt (1). Binnen de nieuwe entiteit heeft na zes jaar reeds een zekere integratie der deelgemeenten plaatsgevonden, en dit verschijnsel speelt niet in het nadeel van de kandidaten der voormalige randgemeenten. Wat de innovatie in raad en kollege betreft, zijn er slechts enkele gevallen aan te halen van een drastische vernieuwing van het 'politiek personeel' n.a.v. de samenvoeging. Veeleer gaat het om een verschuiving in de professionele samenstelling van raad en kollege. Gemeenten met meer dan 5.000 inwoners onderscheiden zich in dit verband reeds van kleinere gemeenten, doordat ze meer beoefenaars van vrije beroepen, zelfstandigen en bedienden in hun bestuurskolleges opnemen. De meest markante verschuiving is evenwel te Oudenaarde vast te stellen : 13 van de 23 raadsleden zijn vrijgestelden van diverse socio-professionele organisaties met nationale organisatiestruktuur. Aansluitend bij het feit dat enkel partijen met nationale signatuur na de fusie in kompetitie blijven, wijzen beide fenomenen op een horizonverruiming van de lokale beleidsformulering.

Het probleem van de vertegenwoordiging van de deelgemeenten wordt door deze ontwikkelingen in een nieuw daglicht geplaatst. In grote fusiegemeenten (zoals Oudenaarde) vervaagt de territoriale binding van de kandidaten en groeit een bredere representativiteit die sterker dan in het verleden op de differentiatie in de politieke opinievorming en de socio-professionele organisatievormen stoelt. Deze ruimere opstelling op fusiegemeentelijk niveau loopt nochtans niet parallel met een hogere gevoeligheid voor de specifieke behoeften- en verwachtingenformulering vanuit de deelgemeenten. Niet ten onrechte werden in de beginfaze centrifugale krachten gekonstateerd, maar deze vaststelling houdt geen afdoende motivering in om niet te streven naar nieuwe vormen van (in)formeel overleg en koördinatie binnen de deelgemeenten en naar een brede

(1) Deze hypothese kon nauwkeurig getoetst worden aan de hand van de Oudenaardse fusie-ervaring. 
dialoog tussen de deelgemeenten en de centrale beleidsinstanties. De noodzakelijke 'eenheid van bestuur' die zowel te Brugge als te Oudenaarde, en - mutatis mutandis - in elke fusiegemeente dringend vereist is m.b.t. de onmiddellijke beleidsopties inzake administratieve reorganisatie en grote infrastruktuurprojekten, mag geen argument vormen om éénzelfde wijze van besluitvorming ook in de sfeer van de sociale en de kulturele voorzieningen te hanteren. In de mate dat de fusiegemeente niet enkel de ontwikkeling van de nieuwe entiteit op het oog heeft, maar ook brede ontplooiingskansen wil geven aan de deelgemeenten, dient de thans eenzijdig centraliserende tendens aangevuld te worden met vormen van gedekoncentreerde probleemformulering en -oplossing. Deze behoefte wordt uiteraard het scherpst aangevoeld bij schaalvergrotingsformules die een reële afstand gekreëerd hebben tussen bestuur en bestuurden. Het uittekenen van een eigen profiel voor de kerkdorpen door het toekennen van specifieke funkties in het kader van een globaal ontwikkelingsplan, is o.i. al even noodzakelijk bij een bescheiden samenvoeging. Ook op kleine schaal kan een eenzijdige centralisatie immers voorbijgaan aan het adagium dat een 'gemeente er (o.m.) is voor de dorpen'.

2.2. Indien zich m.b.t. de samenstelling van raad en kollege van de fusiegemeente slechts markante ontwikkelingen voordoen bij een doorgedreven schaalvergroting (bv. op het formaat van Oudenaarde), dan geldt dit in nog sterkere mate voor de effekten inzake personeelsuitbouw en de binnen-bestuurlijke reorganisatie in het algemeen. Het probleem van de personeelsintegratie, dat vooral op het micro-vlak optreedt, groeit bij grote fusiegemeenten uit tot wat op het eerste zicht een 'personeelsinflatie' lijkt : een drastische uitbouw van het kader, gekoppeld aan een differentiatie van de funkties en een rationalisering van de taak vervulling ( 1 ).

(1) In Oudenaarde liep deze personeelsuitbreiding op van 56 eenheden (totaal van 8 betrokken gemeenten) tot 125 (goedgekeurd kader in 1968) en 189 (kader van 1971), waarvan 136 funkties effektief bezet zijn. In Brugge werden tijdens de eerste twee jaren na de fusie 250 personeelsleden aangeworven (van 900 naar 1.050). 
We hebben gepoogd dit probleem te verklaren tegen een bredere achtergrond. De personeelsuitbreiding is in grote fusiegemeenten inderdaad niet enkel het gevolg van de samenvoeging als zodanig, nl, van de interne hiërarchisering der diensten n.a.v. de integratie, maar al evenzeer van de nieuwe taken, of althans de nieuwe taakdimensies, die de entiteit opgedragen krijgt of zich tot doel stelt. Grote fusiegemeenten zijn nu eenmal niet de som der deelgemeenten. Het worden al vlug gemeenten die een taakprofiel ontwikkelen dat vergelijkbaar is met dit van gemeenten die via een langdurig historisch proces naar dit niveau zijn toegegroeid.

Ondanks een aantal vastgestelde excessen in de beleidsonzekere startperiode, mag men het de grote fusiegemeenten dan ook niet ten kwade duiden dat ze niet beantwoorden aan een simplistische rationaliseringsof zelfs bezuinigingsverwachting (1). De centrale overheid heeft deze feitelijke ontwikkeling ten andere geaccepteerd door ruime personeelskaders goed te keuren, maar komt er de facto niet toe ook de eerder kwalitatieve konsekwenties te onderkennen m.b.t. de beleidsvoorbereiding en -uitvoering. Alle sleutelposities in de nieuwe entiteit worden door geïtegreerde personeelsleden bezet, ook indien ze hiertoe vanuit hun vroegere opleiding en ervaring niet gekwalificeerd zijn. In de technische sfeer worden wel hooggespecialiseerde krachten aangetrokken, maar voor de algemeen bestuurlijke taken geldt nog steeds de traditionele pyramidale struktuur die externe topbenoemingen uitsluit. Alleen Brugge wist dit organigram te doorbreken via de pragmatische weg van de kabinetsvorming. Het is echter zeer de vraag of zulke 'oplossingen' mettertijd de eenheid in de beleidsopbouw niet in het gedrang brengen.

De personeelsintegratie in de kleine fusiegemeenten (en in de centrumsteden die kleinere randgemeenten geintegreerd hebben) heeft in de regel. niet geleid tot een onoverkomelijke bezwaring van het kader. De soepele

(1) Deze les uit het recente verleden heeft het Ministerie van Binnenlandse Zaken nochtans niet tot een beter inzicht gebracht inzake het fenomeen 'bestuurlijke schaalvergroting'. De toekomstige fusiegemeenten ziet men 'groot', maar zullen om budgettaire redenen niet over automatische meerinkomsten kunnen beschikken. Dit 1ijkt ons volkomen inkonsekwent, omdat het een waarachtige beleidsontplooiing in de weg staat. 
oplossingen op het statutaire vlak staan echter in schril kontrast tot de deficiënte reorganisatie van de diensten. Mede omwille van het gebrek aan operationele modellen op het micro-vlak, maar al evenzeer vanwege het niet parallel lopen van de schalvergroting en een innovatie in de bestuursstijl, hebben slechts enkele kleine fusiegemeenten een zinvolle taakverdeling en -specialisatie tussen de geîntegreerde personeelsleden ontwikkeld. De arbeidsmotivering en zelfs de persoonlijke verhoudingen hebben onder dit organisatievacuum geleden. Afgezien van de vraag of samenvoegingen in de toekomst nog op dit formaat wenselijk zijn, kan hieruit toch wel de konklusie getrokken worden dat de verantwoordelijkheid van de centrale overheid niet eindigt bij het vaststellen van een gunstig statuut voor de personeelsleden, maar bovendien ook betrekking heeft op de personeelskwalifikaties en de bestuurlijke organisatiemodellen. Aangezien deze aspekten echter grotendeels onder de bevoegdheid vallen van de autonome gemeenten, zal dergelijke interventie eerder een aanbod moeten inhouden dan een dwingende regel, en kan deze begeleiding wellicht best tot stand komen via de bemiddeling of althans in samenspel met de Vereniging van gemeenten.

2.3. Zoals verwacht kon worden loopt de relevantie van de externe beleidseffekten van de samenvoeging enigszins parallel met de vastgestelde personeelsontwikkeling. Bij een bescheiden schaalverruiming kan men vooral spreken van een draagviakverbreding van het beleid. De beschikbare middelen worden gekoncentreerd onder één bestuursinstantie en in de eerste jaren na de samenvoeging quasi exklusief besteec aan een gelijkschakelingsproces. De kwaliteit van de infrastruktuur en van de voorzieningen wordt opgetrokken tot het hoogste niveau : in de regel dit van de centrum-gemeente. Behoudens een versterking van enkele diensten (gemeentehuis bv., eventueel ook scholen) zal deze centrum-gemeente dan ook meestal niet onmiddellijk genieten van de effekten van de schalvergroting. De deelgemeenten zullen gedurende jaren het hoofdaandeel van de investeringsuitgaven opeisen. Opties in de richting van een reële beleidsinnovatie, bv. inzake socio-kulturele infrastruktuur, worden wel aangetroffen maar zijn in de eerste faze niet aan realisatie toe, juist omwille van de prioritaire nivellering. 
Ook Oudenaarde werd met een belangrijke inhaal-operatie gekonfronteerd, maar deze was van meet af aan ruimer dan een gelijkschakeling van het voorzieningenpeil. Prioritaire optie was hier de ekonomische expansie, in casu een zo goed als 'nieuwe' taak. Er was hiertoe wel een eerste aanloop genomen vóbr de fusie, maar de globale behartiging in agglomeratieverband kon pas starten in 1965. Een periode van $4 \mathrm{jaar}$ (tot 1969) werd gekenmerkt door beleidsvoorbereiding. Pas nadien werden de eerste resultaten zichtbaar, en wel in verschillende beleidssektoren : industrieterreinen, ruimtelijke ordening in het algemeen, huisvesting, restauratie van het kunstpatrimonium en sportinfrastruktuur. Belangrijke projekten staan nog op stapel maar worden voorlopig afgeremd door een onvermijdelijke prioriteitsbepaling. Een definitieve toetsing en evaluatie zal dan ook slechts op langere termijn integraal mogelijk zijn.

Zeker wanneer men rekening houdt met de 'stille periode' bij de start van Groot-Oudenaarde, stelt deze vaststelling wel vragen naar de $z$ in van een evaluatie-onderzoek na 2 à 3 jaar in de andere samengevoegde gemeenten. Zonder de signifikantie van het beschikbare onderzoeksmateriaal te willen overschatten, kan o.i. toch met vrij grote trefzekerheid het fundamentee 1 onderscheid tussen het merendeel der fusiegemeenten en de Oudenaardse test-case vastgesteld worden. Groot-Oudenaarde heeft gestalte gekregen op basis van een konsistent sociaal-ruimtelijk geheel, dat we kunnen omschrijven vanuit drie samenstellende delen $: 1^{\circ}$ een multifunktioneel planningsgebied m.b.t. de lokale bestuurstaak; $2^{\circ}$ het verdichtingsgebied van de veelzijdige attraktie door de 'central place' ; $3^{\circ}$ een (minstens potentiële) koherentie als breed samenlevingsverband. In de allermeeste geanalyseerde gevallen werden de fusiegemeenten nochtans niet op dit model gekoncipieerd : ofwel bereikten ze niet het minimumformat om als planningsgebied in aanmerking te komen, ofwel was hun impakt op de agglomeratie- of streekproblematiek slechts fragmentair vanwege een onevenwichtige uitbouw (bv. Tongeren).

De vraag blijft hierbij open of de gemeenten überhaupt opgetild moeten worden tot een niveau warop ze ook de planningsaspekten van de lokale bestuurstaak kunnen behartigen. Het alternatief van de federatievorming werd vooralsnog niet empirisch onderzocht. Vastgesteld werd alleen dat enkel de gemeenten die manifest (Oudenaarde, Brugge) of embryonaal 
(Roosdaal bv.) aan hogergenoemde criteria voldoen, een onmiskenbaar nieuw beleidsprofiel ontwikkelen. Een systematische vermenigvuldiging van optimaal gestruktureerde entiteiten is ten andere niet haalbaar. De ruimtelijke voorwaarden zijn vaak niet aanwezig maar al evenmin de vitale impulsen op het sociale en ekonomische vlak. Zonder deze potentiële krachten vormt de schalvergroting weliswaar de noodzakelijke, maar niet de voldoende voorwaarde om een administratieve herstrukturering te laten uitgroeien tot een globale ontwikkelingskans in agglomeratie- of streekperspektief.

3. De ervaring met de fusiegemeenten leverde weliswaar enkele indikaties

op voor een meer konsekwente hervorming, maar bood niet de criteria die de toekomstige bestuurlijke schalvergrotingsformules naar inhoud en territorium adekwaat kunnen omlijnen. Elke situatie vraagt dan ook om een veelzijdige en globale doorlichting, waarvan de beleidsanalyse in het perspektief van een doeleindenstruktuur in onze uitgangshypothese een essentiële komponent vormt. We hebben het doeleindenonderzoek op zijn bruikbaarheid getoetst in twee agglomeratie-situaties die als probleemverdichtingsgebieden kunnen doorgaan voor de schaalvergrotingsproblematiek.

3.1. Bij een 'overlay' van de doeleindenstruktuur van de centrumstad Kortrijk met deze van de 8 gemeenten die de Westelijke rand van het stadsgewest vormen, valt allereerst de konkurrentiële positie op die stad en rand innemen m.b.t. het expansiebeleid in het algemeen en het huisvestingsbeleid in het bijzonder. De stad voert een intensieve bouwpolitiek om haar bevolkingspeil op niveau te houden, terwijl ook de meeste randgemeenten hun huisvestingsaanbod afstemmen op de hoge vraag die in het expansieve stadsgewest aanwezig is. Een randgemeente als Marke gaat hierbij zover hár residentiële funktie als uiteindelijke doelstelling naar voor te schuiven, hetgeen meteen ook de betrokkenheid impliceert bij de stedelijke agglomeratievorming.

In de socio-kulturele beleidssfeer doet zich daarentegen een zekere 
taakverdeling voor die het risiko van eenzijdigheid inhoudt. De kulturele voorzieningen $z i j n$ in de regel onderontwikkeld in de rand ten voordele van de sportakkomodatie. Het zich afstemmen op het veelzijdig aanbod van de stad is manifest. Via deze komplementariteit in de beleidsopbouw geven de randgemeenten dus impliciet hun betrokkenheid op de centrum-stad toe. Deze vaststelling volstaat uiteraard niet om de bestuurlijke konsekwenties in alle duidelijkheid af te lijnen. Toch toont het doeleindenonderzoek de noodzaak aan van een eenheidsvisie in het sociaal-ruimtelijk beleid van het stadsgewest en een meer bi1lijke spreiding van de lasten m.b.t. de kulturele voorzieningen. Tevens echter brengen de individuele doeleindenschema's de grotere betrokkenheid bij de agglomeratie van randgemeenten als Marke en Gullegem aan het licht, t.o.v. zich meer autonoom opstellende gemeenten als Moorsele of Wevelgem (1).

3.2. In het kader van het doeleindenonderzoek in de Leuvense agglomeratie konden de randgemeenten op basis van hun representativiteit geselekteerd worden en omwille van hun beperkt aantal en formaat (KesselLo en Herent) heel wat diepgaander geanalyseerd worden. De doeleindenstruktuur van stad en rand brengt hier dan ook meer relevante onderzoeksgegevens aan, die een duidelijker inzicht bieden in de wezenskentrekken van de agglomeratieproblematiek.

Veel vroeger dan de stad Kortrijk werd Leuven gekonfronteerd met het typische agglomeratieverschijnsel van een gesatureerde binnenstad en een $z$ ich sterk ontwikkelende rand. De territoriale beperktheid binnen de historische stadswallen, een in belangrijke mate verouderd en onangepast woningenbestand en het aandeel van gebouwen voor openbaar nut in het globale stadsareaal hebben niet enkel de bevolkingskurve negatief beinvloed maar tevens de 'leefbaarheid' van de binnenstad aangetast.

(1) Ook Bissegem is als randgemeente op Kortrijk aangewezen, maar dan op basis van de morfologische bindingen en niet vanwege het hier gehanteerde criterium. De kulturele voorzieningen zijn er n1. sterk ontwikkeld. Een uitzondering dus die de regel bevestigt. 
In plaats van dit verschijnsel in agglomeratieverband aan te pakken toont de doeleindenstruktuur van Leuven, Kessel-Lo en Herent, dat de zelfstandige gemeenten zich ook de facto autonoom opstellen bij het bepalen van het na te streven toekomstbeeld en de middelen die hiertoe vereist zijn. De stad Leuven wil aldus ten allen prijze het tij van de bevolkingsrecessie doen keren en heeft daartoe ambitieuze bouwplannen voor de city, maar ook voor het enig vrijgebleven terrein binnen de stadsgrenzen, het aangehechte Kareelveld. Of dit gebied in ruimer perspektief niet eerder aangewezen was als 'groene long' voor een reeds overbezette regionale stad, kan gelet op de akute terrein-nood niet in vraag komen.

Ook het morfologisch bij de stad aansluitende Kessel-Lo geeft echter voorrang aan het huisvestingsbeleid. Uit de beleidsanalyse blijkt weliswaar hoeveel aandacht en investeringen naar de vrijwaring en de valorisering van groenruimte gaan, maar het karakter van de gemeente wordt onmiskenbaar residentieel in het kader van de tertiaire tewerkstellingsfunktie van de Leuvense binnenstad (Universiteit, Middelbaar en N.U.H.O., Belgische Boerenbond).

Herent daarentegen dat (nog) niet helemaal morfologisch aansluit bij de stad, al zullen de geografen het terecht tot de agglomeratie rekenen, stelt zich duidelijk verschillend op. Niet alleen geeft het de twee deelgemeenten (Herent-Centrum en Wijgmaal) autonome ontwikkelingskansen en voorzieningen, maar qua globale expansie stemt het zich bovendien in toenemende mate af op de eigen behoeften. Potentieel beschikbare terreinen worden in elk geval niet meer vrijgegeven voor massale woningbouwprojekten om de nochtans aanwezige vraag in stadsgewestelijk verband tegemoet te treden. Dit bevestigt de formeel uitgesproken beleidswil Herent niet (verder) uit te bouwen als een rand-gemeente met een op de centrum-stad afgestemde doeleindenstruktuur, maar de all-round beleidsontwikkeling na te streven van een autonome gemeente in het spanningsveld van de regionale stad.

Een bijkomende karakteristieke uiting van deze autonome opstelling vormt het socio-ku1tureel beleid. Evenals in Kesse1-Lo wordt veel aandacht besteed aan investeringsprojekten voor aktieve en passieve rekreatie, in de lijn van de integrale zorg voor de leefbaarheid van het woonmilieu. Inzake kulturele voorzieningen verwijst Kessel-Lo echter in belangrijke 
mate naar de akkomodatie in de city, terwij1 Herent ze op aangepast format zelf uitbouwt in Herent-Centrum en Wijgmaal. Zoals in bepaalde randgemeenten ten Westen van Kortrijk treedt er aldus tussen de doeleindenstruktuur van stad en rand een impliciete mar niettemin reële komplementariteit op, die de wederzijdse betrokkenheid ontegensprekelijk aantoont. In het geval van Herent is althans de beleids-betrokkenheid bij de stad veel minder exp1iciet.

Binnen de agglomeratie verschijnt aldus een differentiatie in de betrokkenheid bij het centrum, een geleding van de randgemeenten, naargelang ze zich met hun doeleindenstruktuur al dan niet afstemmen op de stedelijke beleidsopbouw. Al moet dit criterium met de nodige omzichtigheid gehanteerd worden met het oog op konklusies naar de bestuurlijke herstrukturering toe, vermits ook andere criteria, bv. van sociaal-geografische of sociaal-ekonomische aard kunnen interfereren, toch liggen in de benadering via het doeleinden-onderzoek een paar operationaliseerbare indikaties besloten. Het ruimtelijk beleid, met de huisvestingsprojekten als meest akute probleemsfeer, moet dringend onder éen beheer gebracht worden, daar waar de doeleinden zich konkurrentieel opstellen, zoals bv. in Kessel-Lo en Leuven. In de socio-kulturele beleidssfeer hoeft wellicht niet eenzelfde drastische ingreep te gebeuren om de manifeste doorverwijzing financieel te kompenseren. Aangezien het nochtans moei$1 i j k$. denkbaar is dat de randgemeenten vrijwillig zouden bijdragen tot de Leuvense inspanning (cfr. de mislukte interkommunalisatie van de kulturele voorzieningen te Kortrijk), dringt zich ook hier een formule op van 'verplichte samenwerking', bv. in het kader van een federatie van gemeenten. De overdracht naar deze suprakommunale instantie van de meest beleidsgevoelige gemeentelijke taken, versterkt echter het alternatief dat de algehele fusie vormt. Voor Herent lijkt een fusie in elk geval minder aangewezen, aangezien de taken die in de toekomst beslist op agglomeratieniveau behartigd zullen moeten worden, zich herleiden tot eerder technische opdrachten (bv. de kontrole op de milieuhinder). De aparte ontwikkeling van Wijgmaal geeft nochtans argumenten aan de voorstanders van een fusie-formule warbij deze deelgemeente omwile van haar industrieel karakter aangesloten zou worden bij de stad, die aldus de beschikking krijgt over het hele industriegebied langsheen het kanaal Leuven-Rupe1. 
4. De analyse van de doeleindenstruktuur kan dus in het kader van de thematiek van dit proefschrift relevant zijn op een dubbel vlak. Ze detekteert taaksferen die voor schaalverruiming in aanmerking komen, zonder nochtans de formule van samenwerking of samenvoeging te preciseren. Bovendien lijnt ze de (deel)gemeenten af die bij deze verruiming betrokken dienen te worden. Toch zal zulke analyse in dit verband steeds een deelonderzoek blijven, dit o.m. vanwege een ingebouwde beperking. Het doeleindenonderzoek kan $n 1$. slechts verwijzen naar een feitelijk aanwezige aandacht bij de beleidsvoerders en een feitelijk gevoerd beleid. In de mate dat deze beleidsopbouw eenzijdig is, geen oog heeft voor weliswaar latente maar niettemin reële problemen, zullen de wetgever of de centrale overheid kunnen interveniëren en meer objektieve maatstaven voor de herstrukturering opleggen. Het gebrek aan een bindende koördinatie van het industrieel beleid bv. wordt noch in de Kortrijkse agglomeratie noch in de Leuvense als een markante lakune ervaren, wellicht omwille van de aandacht die de interkommunales voor streekontwikkeling hieraan besteden. Niettemin is het denkbaar dat de eenheid in beheer van de industrieterreinen binnen de agglomeratie, als een criterium bij de bestuurlijke herstrukturering naar voor geschoven wordt.

Deze precisering mag er $0 . i$. nochtans niet toe leiden het doeleindenonderzoek als een subjektieve benadering te omschrijven t.a.v. een meer objektieve evaluatie van de feitelijk doorgevoerde samenvoegingen. Beide vormen van beleidsanalyse stoelen op een stevige basis van feitenmateriaal, maar houden noodzakelijkerwijze een subjektieve interpretatiemarge in. Vanuit een verschillend uitgangspunt beogen ze éénzelfde problematiek, de gemeentelijke taakbehartiging, te belichten. Deze taakbehartiging nu krijgt gestalte in een bepaald politiek klimaat dat mede de termen zal bepalen waarin de 'bestuurskracht' als richtnorm en toets gehanteerd kan worden. Reeds uit het probleemverkennend dee1 (1) bleek de komplexiteit van dit begrip dat het ontmoetingspunt vormt van efficiënt beheer en demokratische beleidsformulering. Ook bij het afronden van dit proefschrift door het samenbrengen van de empirische onderzoeksresultaten, blijkt een 'gap' te blijven bestaan tussen de wetenschappelijk vast te stellen effekten van de sa-

(1) Met name hoofdstuk II. 
menvoegingen en de indikaties voor schalverruiming aan de ene kant, en de optimale vormgeving van een demokratische beleidsopbouw op lokal vlak. De wetenschap, en met name de bestuurswetenschap, kan op de implikaties wijzen van de alternatieve bestuursmodellen, en bv. komplementair bij de schaalvergrotingsbeweging de noodzaak aantonen van een binnengemeentelijke schaalverkleining naar de kerkdorpen toe. Het eindoordeel over de bestuurlijke hervorming zal echter uit een samenspraak moeten groeien met de politieke besluitvormingsorganen, de enige instanties die geëigend zijn om de samenleving naar de toekomst te oriënteren. 
ABBELOOS J., Bestuurskracht van de gemeenten in Zuid-Limburg in het licht van de schaalvergroting.

Eindverhandeling Faculteit Sociale Wetenschappen, K.U.Leuven, $1973,208 \mathrm{p}$.

AIREN $\eta_{\text {.; }}$ BAETEN E; DELAMARTER Th.; DEPRE R.; QUEVTT M.; VAN HASSEL H.;

WUYIS $\mathrm{H}$., Innovation in Local Covermment.

A Comparative Study of Forty-Four Belgian Townships. Ieuven, 1972.

ANSELIN M., Cudenaarde : stad van 30.000 inwoners.

Oudenaarde, 1966.

AQUINA H.J., Peleidsanalyse in de politicologie, in : Beleid belicht, Dee]. I.

Alphen a.d. Rj.jn, 1972, pp. 39-58.

AUBIN R., Communes et démocratie.

Paris, 1955, 2 delen, 244 en 238 p.

BAHRDT H.P., De leefbare stad.

Utrecht, 1972, $221 \mathrm{p}$.

BAKKER H., Territorlale herindeling, samenwerking en bijzondere bestuursvormen in de sfeer van het lager openbaar bestuur.

Een onderzoek naar situaties en ontwikkelingen in de lid-staten van de Raad van Europa.

Den Haag, 1968, 162 p.

BECKERS F.G.J.H., Lokaal bestuur in Limburg. Enige aspekten van de problematiek der bestuurlijke aanpassing aan het verschijnsel der maatschappelijke schaalverandering. Sittard, 1973, $89 \mathrm{p}$.

BOLAND G., Les problèmes juridiques des fusions de communes, in : Revue de 1 'Administration, 1965, pp. 149-161.

BOURS A., Sociale geografie, stadsgewestvorming en gemeentelijke indeling, in : BOURS en LAMBOOY (red.), Stad en stadsgewest in de ruimtelijke orde.

Assen, 1970, pp. 309-317.

BOURS A. en LAMBOOY J., Stad en stadsgewest in de ruimtelijke orde. Assen, 1970, $334 \mathrm{p}$.

BRASZ H.A., Modern geleed streekbestuur. Alphen a.d. Rijn, 1966, $70 \mathrm{p}$. 
BRASZ H.A., Veranderingen in het Nederlandse Communalisme. Arnhem, 1960, $208 \mathrm{p}$.

BRASZ; DAUDT; GROENMAN; TER HOEVEN, Democratie anno 1967. Werking on feilen van een systeem. Meppe1, $1966,115 \mathrm{p}$.

BRASZ H.A. en de JONG L., Burger en gemeente. Alphen a.d. Rijn, $1968,103 \mathrm{p}$.

BRUGGE M. en DE SMET M., Houding van de inwoners omtrent de fusie van hun gemeente.

Assenede, 1974, $273 \mathrm{p}$.

BRUYNSERAEDE W., Een bestuurskundlge evaluatie van de Groot-Brugse fusie. Eindverhandeling Faculteit Sociale Wetenschappen, K.U.Leuven, 1974. 156 p. + bijlagen.

BULTHUIS J., Samenwerking van gementen. Utrecht, $1957,372 \mathrm{p}$.

BURDEAU G., Traité de science politique ( $2^{e}$ édition). Paris, $1966+$ ssq.

BUURSINK J., Centraliteit en hiërarchie. De thoorie der centrale plaatsen in enkele Nederlandse industriegebieden. Assen, 1971, $211 \mathrm{p}$.

CARO F.G. (red.), Readings in evaluation research. New York, 1971, $418 \mathrm{p}$.

CIRISTALIER W., Die zentralen orte in Suideutschland. Jena, 1933.

CONSTANDSE A.K., Het dorp in de IJsselmeerpolders. Zwolle, 1960.

CONSTANDSE A.K., Planning van het kernenpatroon en optimale opbouw van plattelandskernen, in : Planning van het platteland, Colloquium van 'Wens en Ruimte' v.z.w. op 2-3 december 1971, pp. 33-44.

DAENENS M. e.a., Elementen van een beheersmodel voor de agglomeraties en federaties van gemeenten. Brussel, I.A.U., 1972, 54 p.

DE JONG L., Publiekgerichte overheidsorganisaties. Amsterdam, 1972.

DELMARTINO F., Decentralisatie en lokaal bestuur. Enkele kanttekeningen rondom de Zweedse situatie, in : De Gemeente, 1973/6-7, pp. $383-385$. 
DELMARTINO F., De fusie van kleine gemeenten. Kritisch onderzoek naar mogelijkheden en realisaties.

Eindverhandeling Instituut Poljtieke en Sociale Wetenschappen, K.U.Leuven, $1967,187 \mathrm{p}$.

DEIMARTNO F., De herstrukturering en herwardering van de lokale besturen in Zwoden, in : De Gemeente, 1974/3, pp. 156-163.

DEPRE R., De personeelsuitbouw in de Belgische steden. Onderzoek naar de personeelsplanning in de overheid. Leuven, V.C.B.A., 1974.

DEPRE R. en VAN HASSEL H., Management in het lokale bestuur. Brussel, I.A.U., 1969, 71 p.

DERHAEG P., De bestuurskracht van het lokale bestuur in het licht van de schealvergroting.

Licentiaatsverhande Jing Faculteit Sociale Wetenschappen, K.U.Leuven, 1972,216 p. + bijlagen.

DEVENMNS A.M., De samenstelling van de beleidsorganen on de personeelsbezetting als elementen van gomeentelijke bestuurskracht. Situatieverkenning van de gemeenten in Zuid-Timburg. EIndverhandeling Faculteit Sociale Wetenschappen, K.U.Leuven, 1974, 140 en $124 \mathrm{p}$.

DROR Y., Public policymaking reexamined. Scranton (Penns.), 1968, $370 \mathrm{p}$.

DROR Y., Ventures in policysciences : concepts and applications. New York, 1971.

ENGELSMAN P. en HARTOG J., Optimale grootte van stadscewesten. Delft - Rotterdam, 1969, $122 \mathrm{p}$.

ETZIONI A., The active society - A theory of societal and political processes. Lond on, 1968, $698 \mathrm{p}$.

EVERAET H., De leefbaarheid van het platteland, in : Polltica, 1967, 3 , pp. 229 ssq.

FABER S., Burgemeester en democratie.

Alphen a.d. Rijn, 1974.

FALYS $J$. en ORIANNE $P$., Les communes belges et leur avenir. Brussel, 1974, $208 \mathrm{p}$.

FREEMAN H.E. and SHERWOOD C.C., SOclal research and social policy. Englewood Cliffs, 1970, 159 p. 
GEERONS-VERCRUXSSE A., Evaluatie van de reeds gerealiseerde samenvoegingen in West-Vlaanderen. Brussel, 1974, $120 \mathrm{p}$.

GOOSSENS M., Hiërarchie en hinterlanden der centra. Een methodologische studie toegepast op Noordoost-Belgiè.

Leuven, 1963.

GOOSSENS M.; DE VEUSTER J.; DANIELS J., De hoofddorpen in het hiërarchisch stedenpatroon van België. (Recks : Eclectica, nrs. 5-6). Brussel-Antwerpen, 1972, $140 \mathrm{p}$.

GOOSSENS M. en VAN DER HAEGEN H., Het sociaal-geografisch onderzoek in Belgjë, basis voor nieuwe mimtelijlse organisatie-eenheden, in : De ruintelijke omvang van plannings- en bestuurlijke eenheden.

Leuven, 1972, pp. 3.1-49.

GROENMAN Sj., De gemeente als veld en rayon, in : Sociaal-wetenschappelj.jke verkenningen.

Assen, 1956, pp. 150-157.

GROENMAN Sj., Goede kanten van kleine gemeenten.

Opgenomen in : Perpetuum Mobile.

Assen, 1974 pp. 159-166.

GROENMAiN $\mathrm{Sj}_{j}$, Ons deel in de ruimte.

Assen, 1959, $152 \mathrm{p}$.

GROENMAN Sj., Perpetuum Mobile. Thema's en toepassingen in de sociologie van Groenman.

Assen, 1974, $208 \mathrm{p}$.

GROENMAN Sj., Uitdijende werelden. Oratie te Ieiden op 5 oktober 1956. Opzenomen in : Perpetuum Mobile.

Assen, 1974, pp. 26-37.

GROENMAN Sj.; KESSEL A.L.; GUNIHER A.H., De bestuurskracht der kleinere gemeenten.

Alphen a.d. Rijn, 1961, 62 p.

GROOT J.P., De leefbaarhe1d van de dorpen in de gemeente Borger. Een methodologische studie inzake de waardering van het wonen in plattelandskernen.

Wageningen, 1969, $147 \mathrm{p}$.

GROOT J.P., Het kleine dorp. Overlevingskansen van en perspectieven voor dorpen en buurtschappen in Nederland.

Baarn, $1974192 \mathrm{p}$. 
GROOT J.P., Kleine plattelandskernen in de Nederlandse samenleving. Schaalvergroting en dorpsbinding.

Wageningen, 1972, $261 \mathrm{p}$.

GUFFENS Th., Gemeenten in het spanningsveld van een stad. Een sociologische beschouwing van naturlijke ontwikkelingen en gemeentelijk beleid in het achterland van Ni.jmegen. Nijmegen, 1968, 3 delen.

HARDEMAN J., Enkele bedenkingon over de schaalvergroting op het platteland, in : De Gemeente, 1975/2, pp. 97-104.

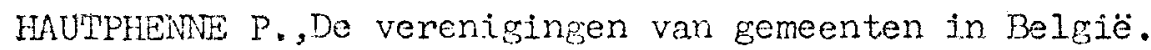

Brusse1, V.B.S.G., 1966, 295 p.

HOLVOET Baron, De grote stedelijke agglomeraties.

Brusse I, 1937.

HOOGERWERF A. (red.), Beleid belicht. Sociaal-we tenschappelijke beleidsanalys Alphen a.d. Rijn, 1972, 2 delen, 230 en 139 p.

HOOGERWERF A., De analyse van de beleidsinhoud, in : Beleid belicht, deel I. Alphen a.d. Rijn, 1972, pp. 83-101.

HUMES S. en MARTIN E., The structure of Local Governments throughout the Worl Den Haag, 1961, 449 p.

HYMAN H.H. en WRIGHT C.R., Evaluating social action programs, in :

F.G. CARO (red.), Readings in evaluation research, New York, 1971; p. 187 ssq.

IN 'T VELD-LANGEVELD H.M., Beleidsevaluatie, politiek en bestuur, in : Polj.tisering van het Openbaar Bestuur. I.B.W.reeks $\mathrm{nr}$. 22. 's Gravenhage, 1974, pp. 162-171.

IN ' $T$ VELD-LANGEVEID H.M., De evaluatie van het beleid, in : Beleid Belicht I. Alphen a.d. Rijn, 1972, pp. 204-224.

KALLEN R. (red.), De afstand tussen burgers en hun gemeentelijke overheden. Deventer, N.I.M.O.-cahier, nr 15, 1974, 116 p.

KIEIJN A. e.a., Over schaalvergroting. Utrecht, 1968, $193 \mathrm{p}$.

KLONNE A., Zum Begriff und zur Realität von politischer Gemeinde, in : R. ZOLL Gemeinde als Alibi. München, 1972, p. 250 ssq.

KONIG R., Grundformen der Gesellschaft : Dle Gemeinde. Hamburg, 1958. $200 \mathrm{p}$.

KONIG R., Soz1ologie der Gemeinde, in : Kölner Zeitschrift für Sozlologie und Sozlal-Psychologie. 1955. Sonderheft 1. 
KORIRIJK Stad, Aanvraag tot indeling van de stad in een hogere klasse. Rapport van het kollege van burêmeester en schepenen aan de gemeenteraad.

Kortrijk, 1971.

KOTTGEN A., Der Strukturwandel des flachen Landes als Verwaltungsproblem, in Archiv für Kommunalwissenscharten, 1962/3, pp. 155-178.

KOTTGEN A., Die Gemeinde als Cegenstand wissenschaftlicher Forschung, in : Archiv für Kommunalwissenschaften, 1962/1, pp. 3-26.

KOTIGEN A., Kommunale Selbstverwaltung zwischen Krise und Reform. Stuttgart, $1968,292 \mathrm{p}$.

KRUIJER G.J., Organiseren en evalueren. De rol van de wetenschappelijke adviseur in beleidsprocessen. Meppe1, 1969, $299 \mathrm{p}$.

KUYPERS G., Grondbegrippen van politiek. Utrecht, 1973, $304 \mathrm{p}$.

IAMBOOY J., Bestuurlijke- en planningsgewesten, in : De ruimtelijke omvang van plannings- en bestuurlijko eenheden. Leuven, 1972, pp. 2.1-17.

IEEMANS A.F., Changing Patterns of Local Government. 's Gravenhage, 1970, 224 p.

LEEMANS A.F., De eerheid in het bestuur der grote stad. Leiden, 1967, $469 \mathrm{p}$.

LINDBIOM C.E., The policymaking process .

Englewood Cliffis, 1968, 122 p.

MAES R., De bestuurskracht van de Belgische gemeente, in Res Publica, 1970/3, pp. $427-456$.

MAES R., De gemeente en de hedendaagse democratie, in : Gemeentebeleid 1970-1980, Cepess-documenten, 1969/VIII, 5-6.

MAES R., De herstructurering van de gemeenten, in : De Gemeente, 1975/1, pp. $12-25$ en 1975/2, pp. 76-97.

MAES R., Fusie-federatie : Noodzaak van draagvlakstudies, in : Gemeente en Provincle, jan.-febr. 1975, pp. 17-23.

MAES R.; NIJS V.; DE VEUSTER J.; DELMARTTNO F.; REYNDERS M., Maatschappelijke ontwikkeling en bestuurlijke vormgeving in Zuld-Limburg. Studie van de herstrukturering van gemeenten. Hasselt, 1974,268 p.

MARCH H.A. and SIMON J.G., Organizations. New York, 1958, 262 p. 
MAST A., Ie contenu spécifique de l'intérêt communal, in : L'autonomie communale en droit belge. Brussel, 1968. pp. 31-52.

MATIENKLODT H.F., Gebicts- und Verwaltungsreform in der Bundesrepublik Deutschland. Muinster, 1972, $392 \mathrm{p}$.

NIJK A.J. e.a., De mens in de stad van de mens. Alphen a.d. Rijn, 1969, 199 p.

PAEME L., De lokale besturen en de economische expansie.

Eindverhandeling Instituut voor Politieke en socjale Wetenschappen K.U.Ieuven, 1968, $203 \mathrm{p}$.

PETERS H., Handbuch der kommunalen Wissenschaft und Praxis. Berlin, 1956-1959, 3 delen, 954 p., 692 p. en 1.062 p.

RHEIN H.L., Nodelle zur kommunalen Neuordnung im Einzugsbereich der städte unter weitgohender Aurrechterhaltung der gemeindlichen

Selbständigkeit. Köln, $1970,130 \mathrm{p}$.

ROBSON W.A., Iocal Government in Crisis. London, 1965, $175 \mathrm{p}$.

ROSSI P.H., Evaluating social action programs, in F.G. CARO (red.), Readings in evaluation research.

New York, 1971, p. $276 \mathrm{ssq}$.

ROUSSIIJON H., Les structures des communes. Réformes et perspectives d'avenir. Paris, 1972, $491 \mathrm{p}$.

SAAL C.D., Sociale dynamiek. Structuurveranderingen in de plattelandssamenleving.

Grontngen, 1952.

SCHEUNER U., Gemeindeverfassung und kommunale Aufgabenstellung in der Gegenwart, in : Archiv für Kommunalwissenschaften, 1962/2, pp. $149-178$.

SCHEUNER U., Zur kommunalen Verwaltungsreform in Deutschland.

Problematik und geschichtlicher Riickblick, in : Archiv für Kommunalwissenschaften, 1969/2, pp. 209-248.

SCHEUNER U., Zur Neubestimmung der kommunalen Selbstverwaltung, in : Arohiv für Kommunalwissenschaften, 1973 - I, pp. 1-44.

SENELLE R., Planning en gemeentelijke autonomie. Kongres van de V.B.S.G., november 1973.

SMIT 0., Participatie in bestuurlijke besluitvorming. Verslag van een onderzoek naar het kontakt tussen bestuursorganisaties en individuele burgers. Amsterdam, 1973. 
SUCHMAN E.A., Evaluative research. Principles and practice in public service and social action programs.

New York, $196 \%$.

TEN BERGE.G., Het platteland : proeftuin voor gedecentraliseerd bestuur ?

Een onderzoek naar de gevolgen van de geneentelijke herindeling voor de bevolking en de overheid op het eiland Tholen. Utrecht, $1974,275 \mathrm{p}$. + bijlagen.

THUNG M.A., Integratie op lokal niveau.

's Graverhage, Publikaties van de Nationale Raad voor

Maatschappelijk Welzijn, nr 34, 165, pp. 13-ja.

THUNG M.A., Sociolog'sche interpretaties van 'schaalvergroting', in: Over schaalvergroting, utrecht, 1968 pp. 42-59.

TINDENANS L., Het geregionaliseerde België, overgang van de Natie-Staat naar de plurinationale Staat, in Teksten en Dokumenten van het Ministerie van Buitenlandse Zaken, aug.-sept. 1972.

TONKENS E., De leefbaarheid van het platteland, in : Mens en Maatschappij, $1950 / 35$, pp. $1-13$.

VAN DAALEN P., Bestuur voor mensen. Besluitvorming in de verzorgingsstaat. Meppe 1, 1973, $193 \mathrm{p}$.

VAN DE LEST J.. Schaalvergroting en ruimtelijke structuren, in : over schaalvergroting, Utrecht, 1968, pp. 29-41.

VAN DER TOP G.J., Samenvoeging van gemeenten. Assen, $1960,186 \mathrm{p}$.

VAN DOORN J.A.A., De sociale levensvatbaarheid van de kleine pladtelandskern. Problematjek - analyse - beleid.

Den Haag, 1961, $45 \mathrm{p}$.

VAN DOORN J.A.A., Schaalvergroting als een proces van sociale verandering, in : Sociologische gids, 1960, nr. 7 .

VAN DUYNE D., Prospectief bestuur. Arnhem, 1964, 240 p.

VAN HECK B.C., Afbakening en typologie van homogene zones. Assen, 1965, $245 \mathrm{p}$.

VAN HECKE E., Les fusions de communes : 1964-1971, in : Courrier hebdomadaire du C.R.I.S.P., 25.11.1971.

VAN HOUTEN D., Toekomstplanning. Planning als veranderingsstrategie in de welvaartsstaat.

Meppe1, 1974, $200 \mathrm{p}$. 
VAN RULTER H., Aggloneratie-problematiek in Nederland. Verslag van een onderzoek naar het feitelijke verloop van het openbaar bestur in Nederlandse ageloneraties op het gebied van de overheidstaak rujintelijke ordening. Alphen a.d. Rijn, 1972, 290 p.

VAN RULTER H.; VROON A., Gemeentelijke zelf'stendigheid. Enkele bestuurskundis notities rondom cen analyse van de posten op de uitgavenkant van de gewone diensi van de gemeentebegrotingen van een regentiental Noordimburgse gemeenten, in : Bestuurswetenschappen, 1972, pp. $217-233$.

VAN STEENBRUGGE A., De actie tot industriële expansie van de stad Oudenaarde in de laatste twintig jaar.

EIndverhandeling Economische Wetenschappen, R.U.Gent, 1972, $158 \mathrm{p}$.

VANTHUMN $\mathrm{J}$., Het secundaire verzorgingsgobied als basis voor meer eenvormige administratieve structuren.

Eindverhandeling R.U. Gent, 1957,97 p. + bijlagen.

WAGENER F., Neubau der Verwalturig.

Berlin, 1969.

WAIDO D., The administrative state.

New York, 1948, $227 \mathrm{p}$.

WISSINK G.A., Plaats en taak van de Nederlandse gemeenten in de regionale on twikkeling, in BOURS en LAMBOOY (red.), Stad en stadsgewest in de mintelijke orde.

Assen, 1970. pp. 192-207.

WISSINK G.A., Stadsgewesten als spel van krachten. Verschuivende perspectieven voor landelijke gebieden. Verslag van de gastcolleges aan de K.U.Leuven, 28-29 februari 1968 . Leuven, I.I.S.R.O., 1968, 14 en 13 p.

ZIEBILL 0., Kommunale Selbstverwaltung und Politische Wissenschaft, in : Archiv für Kommunalwissenschaften, 1964/1, pp. 25-40.

ZOLT R., Gemeinde als Alibi. Materialen zur politischen Soziologie der Gemeinde.

München, $1972,276 \mathrm{p}$.

Bestuurlijke Organisatie. Gedachten over afstemning van het lokale bestuur". op de eisen van de matschappelijke ontwikkeling.

's Gravenhage, V.N.G., 1969, 99 p.

Bestuursonderzoek Oost-Nederland. Bestuurskundig deelonderzoek door de V.U. Amsterdam.

Ams terdam, 1974. 
Die Verwaltungsregion. Aufgaben und Verfassung elner neuen Verwaltungseinheit (Schriftenreihe des Vereins für Kommunalwissenschaften, $\mathrm{nr}, 16$ ).

Stuttgart, 1967, 155 p.

Dokumentation iber die Verwaltungsreform in Baden-Württemberg.

Stuttgart, 1972.

Fédérations de communes et grandes agglomérations urbaines.

Brusse 1, V.B.S.G., 1968, 202 p.

Fusies en federaties van gemeenten in het arrondissement Kortrijk.

Rapport van de A.C.W. -werkgroep.

Kortrijk, 1972, 34 p. + bijlagen.

Grenzen en mensen. Deel I : Iiteratuurstudie en onderzoeksvoorstellen m.b.t. de herindeling van de 62 gemeenten in Zuid-Limburg.

Nijmegen, 1969, 131 en XI p.

Kleine dorpen in Limburg. Een verkennende studie inzake de sociale leefbaarheidsproblematiek van het landelijk gebied in Limburg.

Maastricht, $1966,84 \mathrm{p}$.

L'autonomie communale en droit belge. Travaux du colloque tenu à Huy et Spa du 8 au 11 septembre 1966.

Brussel, 1968, 438 p.

Leuven 2000 : Survey van het Stadsgewest. Tekstdeel van de Survey Leuven 2000 Kernstad en Stadsgewest, onder red. van H. Van der Haegen.

Leuven, 1974, $78 \mathrm{p}$.

Principer för en ny kommunindelning.

Stockholm, 1961, $248 \mathrm{p}$.

Royal Commission on Local Government in England (Redcliffe - Maud Commission) Vol. 1 : Report.

London, 1969, $376 \mathrm{p}$.

Samenleving en bestuur in de regio Zwolle.

's Gravenhage, V.N.G., 1974, 3 delen.

Stadsgewest Oostelijk Mijngebied : Bestuurlijke organisatie. Heerlen, 1970, 99 p. + bijlagen. 
BIJIAGE 1. Overzicht van de fusiegemeenten in Vlaanderen

Voor elk der' fusiegemeenten, ingedecld naargelang de 'fusiegolf' (1.964 en 1970-1971) en per provincie, wordt aangegeven :

- de naam der samenstellende deelgemeonten;

- de verstedelijkingsgraad der deelgemeenten op 31 december 1961. Deze indeling is gebaseerd op de 'Typologie van de Belgische Gemeenten naax Eraad van verstedelijking' van de hand van $H$. VAN DER HAEGEN en W. VAN WAELVELDE (Statistisch tijdschrift, 1967, ar. 9). Zij onderscheiden volgende gemeentetypen :

\section{Plattelandsgemecnten}

Agrarische gemsenten

Gementen met agrarisch karakter

Gemengde plattelandsemeenten

Landelijke woongemeenten

Verstedelijkte gemeenten

Verstedelijkte woongemeenten

Kleine industriecentra en gemeenten

met belangrijke werkfunkties

Gemengde verstedelijkte gemeenten met sterk ontwikkelde ingaande en uitgaande pendel

Gemengde verstedelijkte gemeenten met minder sterk ontwikkelde pendel

\section{Steden en stedelijke agglomeraties}

Gewone steden

Reglonale steden

Grote agglomeraties
GS

\section{onze afkorting}

$A G$

AK

GP

IW

$\mathrm{VW}$

GMW

GVSP

GVMP

RS

GA

- bevolking van de deelgemeenten op 31 december 1961;

- bevolking van de fusiegemeente op 31 december 1970;

- oppervlakte in ha. op 31 december 1970;

- datum van het samenvoegingsbesluit (K.B.) en van de bekrachtigingswet. 


\section{A. Fusiegolf 1964}

Provincie ANTWERPEN

1. BERLAAR Berlaar Gestel

Provincie BRABANT

I. BOUTERSEM (I)

Boutersem

Vertrijk

2. HONSEM

Meldert

Neervelp

Opvelp

Willebringen

3. ROOSDAAL

O.L. Vrouw-Iombeek

Famel

Strijtem

4. WALSHOUIEM

Waasmont

Walsbets

Walshoutem

Wezeren

\section{Provincie LIMBURG}

1. BREE

Beek

Bree

Gerdingen

2. HAIEN

Halen

Loksbergen
VW

VW

1.805

783

$A G$

.853

AG $\quad 479$

$A G \quad 733$

AK 673

$\begin{array}{lr}\text { LW } & 829 \\ \text { VW } & 5.193 \\ \text { VW } & 1.236\end{array}$

VW

VW

VW

AK

2.504

2.629

1.129

10.4 .64

2.7 .64

7.709

1.720

10.4 .64

2.7 .64

2.856

1.497

1.007

368

1.405

222

3

.230

20.3 .64

2.7 .64

2.354

$$
2.7 .64
$$

$$
2.7 .64
$$

18.6 .64

6.7 .64
5.5 .64

2.7 .64

$\begin{array}{lr}\text { AK } & 790 \\ \text { GS } & 7.031 \\ \text { WW } & 2.047\end{array}$

10.389

4.916

10.4 .64

2.7 .64

5.322

2.602

20.3 .64

2.7 .64

(1) Boutersem werd in 1970 bij een nieuwe samenvoeging betrokken. Deze gegevens betreffen alleen de eerste fusie-operatie. 
Provincie OOST-VLAANDWREN

1. BUGGENHOUT

Buggenhout

Opdorp

2. MERELBEKE

Merclbeke

Lemberge

3. OUDFNAARDE (1)

Bevere

Edelare

Eine

Ename

Leupegem

Nederename

Oudenaarde

Volkegem
GMN

IW

GN

GVMP

GVMP

$\mathrm{VW}$

GMN

VW

GS

VW
12.266

10.019

1.690

$\mathrm{WW}$

13.837

1.904

18.6 .64

6.7 .64

6.7 .64

2.820
1.085
4.133
1.609
2.005
2.021
6.923
686

22.019

3.006

20.3 .64

2.7 .6

Provineie WEST-VIAANDERES

1. DIKSMUIDE

Diksmuide

Esen

Kaaskerke

GS

$\mathrm{AK}$

AK

6.669

2.838

10.4 .64

3.812

1.888

543

2. IZFGEM

Emelgem

GHW

4.729

Izegem

GS

17.095

3. ROESEIARE

Beveren

GVMP

3.366

GS

GS $\quad 35.645$

1.968

1.6 .64

6.7 .64

Roeselare

3.382

1.6 .64

6.7 .64

(1) Oudenaarde werd in 1970 bij een nieuwe samenvoeging betrokken. Deze gegevens betreffen alleen de eerste fusie-operatie. 


\section{B. Fusiegolf 1970-1971}

Provineie ANTIERPEN

1. VEERLE

Varendonk

LN

Veerle

WW

297

4.364

1.759

8.12 .70

9. 4.71

2. WESTERIO

Tongerlo

Westerlo

Zoerle-Parwijs

$\begin{aligned} \text { VN } & 4.002 \\ \text { GVIP } & 7.297 \\ \text { VW } & 1.471\end{aligned}$

14.173

4.874

31.3 .70

$17 \cdot 7.70$

Provincie BRABANT

1. AITEKHOVEN

VW

2.224

899

5. 6.70

Atterhoven

1.931

Neerlanden

VW

356

2. BOUTEFSEM

Boutersem

Kerkom

WW

IN

1.805

987

Roosbeek

VW

1.333

3. DIEST

Diest

Webbekom

GS

9.816

IW . 931

10.799

1.362

8.12 .70

9. 4.71

4. HALTE-BOOIENHOVEN

Dormaal

GVMP

Halle--Booienhoven

631

$\mathrm{AK}$

2.019

2.537

1.736

31.3 .70

$17 \cdot 7.70$

5. KUMTICH

Kumtich

LW

1.907

Vissenaken

AK

1.131

6. IANDEN

Landen

Rumsdorp

VW

VW

4.970

265

7. LINTER

Drieslinter

VW

Neerlinter

1.381

VW

1.418

8. NEERWINDEN

Eliksem

IW

Ezemaal

Laar

Neerwinden

Overwinden

Wange

5.740

962

5. 6.70

$17 \cdot 7.70$

270

1.236

8.12 .70

9.4 .71

3.217

1.966

$27 \cdot 5 \cdot 70$

17.7 .70 
9. ORSMAAL

Nie jkwezer

Neerhespen

Orsmaal-Gussenhoven

Overhespen

10. RUMEN

Grazen

Rummen

11. TIENEN

Bost

Oorbeek

Tienen

12. ZOUTLEEUN

Helen-Bos

Zoutlceuw
$A G$

GP

$A K$

VW

IN

AK

IW

IW

GS

IN

GVMP
2.192

499

428

788

474

566

925

2.604

24.134

1.259

305

22.736

3.068

397

2.549
1.635

24.12 17.7.

24.12. 17.7.

16. 6.7 17.7 .7

8.12. 9. 4.7

\section{Provincie IIMBURG}

Arrondjssement HASSELT

1. AS

As

Niel-bij-As

WW

3.769

VW

1.002

5.496

2.206

$27 \cdot 5 \cdot 7$

17.7.

2. BORLO

Borlo

Buvingen

IW

IN

Kerkom

Mielen

Muizen

AK

$A K$

$A G$

3. BRUSTEM

Aalst

Brustem

Ordingen

GMN

2.472

2.029

5. 3.

17.7.

349

491

790

125

4. DURAS

Duras

Gorsem

Runkelen

GVMP

Wilderen

5. GELMEN

Enge Imanshoven

Gelinden

Groot-Gelmen

LW

VW

IW

666

4.252

1.490

2.102

946

374

400

IW

392

695

GP

714

GP

415

2.828

1.542

27.5.

17.7.

5. 3.7

17.7.

IW 
6. GINGEIOM

Gingelom

Niel-bij-St. Truiden

Wit

VW

1.463

2.294

1.245

31.3 .70

17.7 .70

7. HERK-DE-STAD

Donk

Herk-de-Stad

LW

GP

5.733

2.588

1.253

4.057

8. JEUK

Boekhout

LN

312

Jeuk

WW

1.409

9. KERMT

Kermt

Spalbeek

VW

2.407

VW

1.389

10. KOZEN

Kozen

Wijer

AK

1.241

LW

1.004

11. KURINGEN

Kuringen

Stokrooie

GVMP

5.969

1.364

1.711

1.184

4.550

1.228

2.545

1.163

8.583

2.580

1.885

1.626

VW

Montenaken

Kort1js

Vorsen

AK

1.500

242

LW

247

13. NIEUWERKERTIEN

Binderveld

Nieuwerkerken

IW

WW

14. SCHULEN

Berbroek

Schulen

VW

VW
23.3 .70 17.7 .70

23.3 .70 17.7 .70

31.3 .70 17.7 .70

12.3 .70 17.7 .70

31.3 .70 $17 \cdot 7.70$

5.3 .70 17.7 .70

5.3 .70 17.7 .70$$
17.7 .70
$$

GVMP

GP

Reppel

2. DILSEN

Dilsen

Elen

Lanklaar

Rotem

Stokkem
VW

VW

GVMP

GMW

VW
532

2.286

1.012

2.005

5.163

591

3.306

3.042

1.180

1.695

31.3 .70 17.7 .70

3. GRUITRODE 
4. KINROOI

Kessentch

Kinrooj.

Molenbeersel

Ophoven

5. MEEUWEN

Ellikom

Meeuwen

Wijshagen

6. OPITIER

Opitter

Toneerlo

7. PEER

Kleine-Brogel

Peer

1.003

5.838

1.401

2.022

2.323

2.214

685

$\begin{array}{lr}\text { VW } & 3.543 \\ \text { AK } & 635\end{array}$

$\begin{array}{lr}\text { VW } & 3.543 \\ \text { AK } & 635\end{array}$

VW

1.205

876
5.475

8.12 .70

9.088

6.160

5.147

$27 \cdot 5 \cdot 70$

17.7 .70

2.7 .19

1.572

$27 \cdot 5 \cdot 70$

17.7 .70

7.201

5.506

31.3 .70

$17 \cdot 7 \cdot 70$

Arrondissement TONGEREN

1. BOVEIJINGEN

Meche Jen-Bovelingen

Rukke lingen-Ioon

2. ELDEREN

Genoelselderen

's Herenelderen

Membruggen

3. HAREN

Bommershoven

Plringen

Widoole

4. HEERS

Batsheers

Gutschoven

Heers

Mettekoven

Opheers

Veulen

5. HEKS

Heks

Horpmaal

Vechmaal

6. HOESEIT

Hoeselt

Romershoven

Werm
WW

VW

LW

IW

IN

AK

$\mathrm{AK}$

$\mathrm{AK}$

$\mathrm{AG}$

IW

VW

LW

LW

IW

AK

AK

AK

VW

IW

AK
1.232

427

507

571

768

1.758

832

23.3 .70 17.7 .70

2.212

1.302

$27 \cdot 5 \cdot 70$ 17.7 .70

2.185

1.438

81.9

862

432

3.178

2.418

149

314

1.677

202

392

477

1.709

469

664

615

6.884

5.101

664

430

1.770

31.3 .70 17.7 .70

22.4 .70 17.7 .70

31.3 .70 17.7 .70

$27 \cdot 5 \cdot 70$ 17.7 .70 
7. KOLMONT Jesseren Overrepen

8. MAASMECHELEN

Eiscien

Mechelen aan de Maas

Opgrimbie

Vucht

9. MOPHRTINGEN

Hees

Mopertingen

Rosneer

10. LEUT

Ieut

Meeswijk

11. SPOUWEN

Grote-Spouwen

Kleine-Spouwen

Rijkhoven

12. ST. TRUIDEN

Halmaal

St. Truiden

13. TONGEREN

Berg

Henis

Koninksem

Neerrepen

Riksingen

Tongeren

14. VREREN

Diets-Heur

Vreren
AK

GP

GS

VW

VW

VW

VW

AK

LW

WW

VW

1.259

846

GP

GP

LW

GVMP

GS

LW

IN

GP

IW

VW

GS

VW

IW

595

626

8.875

6.669

1.691

3.109

780

1.040

793

1.257

829

1.087

20.776

746

532

747

304

862

16.176

486

970
1.300

2.100

2.671

1.048

31.3 .70

17.7 .70

$5 \cdot 6.70$

$17 \cdot 7 \cdot 70$

31.3 .70

17.7 .70

24.729

5.834

16.6 .70

17.7 .70

3.317

1.263

$27 \cdot 5 \cdot 70$

17.7 .70

21.473

4.301

31.3 .70

17.7 .70

20.136

3.082

8.12 .7

$1.658 \quad 1.089$

31.3 .70

17.7 .70

\section{Provincie OOST-VLAANDEREN}

1. BRAKEL

Elst

Michelbeke

Nederbrake 1

Opbrakel

Zegelsem

2. DEINZE

Astene

Deinze

Petegem/Leie

Zeveren
GP

GP

GS

GP

IW

GVMP

GS

GVMP

AK
1.114

988

6.509

1.618

1.202
11.348

2.459

6.004

5.750

600

16.711
3.550

16.6 .70

17.7 .70

3.145

24.12 .65

17.7 .70 
3. DENDERMONDE

Appels

Dendermonde

Sint-Gilles

4. GERAARDSBERGEN

Geraardsbergen

Goeferdinge

Nederboelare

onkerzele

Overboelare

5. KLUISBERGEN

Berchem

Kwaremont

Ruien

Zulzeke

6. MUNKZWAIM

Beerlegem

Dikkele

Hunde lgem

Meilegem

Munkzwalm

Paulatem

Roborst

Rozebeke

St.Blasjus-Boekel

St. Denijs-Boekel

st.Maria-Latem

7. OUDENAARDE

Heurne

Mater

Melden

Oudenaarde

Welden

8. WORTEGEM-PETEGEM

Elsegem

Moregem

Petegem a.d. Schelde

Wortegem

9. ZOTTEGEM

Elene

Erwetegem

Godveerdegem

Grotenberge

Leeuwergem

St.Goriks-Oudenhove

Strijpen

Velzeke-Ruddershove

Zottegem
VW

2.670

GS

$\mathrm{WW}$

GS

GMN

VW

$\mathrm{VW}$

GMN

GVMP

$A K$

GVMP

AK

9.582

1.045

1.086

2.728

3.746

17.533

2.362

1.011

2.478

691

$6.253 \quad 3.052$

6.356

314

AK

AK

GP

IW

$V W$

AK

LW

LW

LW

GP

VW

GP

$G P$

$G P$

GS

LW

GVMP

AK

GP

AK

631

2.171

896

6.923

1.085

497

344

1.520

136

797

391

668

944

644

$26.615 \quad 6.322$

$4.897 \quad 3.707$

1.143

370

1.558

1.876
8.12 .70

9.4 .71

2.236

4.12 .6

$17 \cdot 7.7$

16.6 .70

17.7 .70

20.6 .70

$17 \cdot 7 \cdot 70$

$20 \cdot 6.70$

$17 \cdot 7 \cdot 70$

16.6 .70

17.7 .70

$21.461 \quad 4.969$

31.3 .70

1.061

VW

2.503

VW

811.

GVMP

1.301

VW

1.309

LW

866

VW

2.903

VW

3.133

GS

6.630 
Arrondissement BRUGGE

1. BLANKENDERGE

Blankenberge

Uttkerke

2. BRUGGE

Asscibroek

Brugge

Dudzele

Koolkerke

Iissewege

St. Andries

St. Kruis

St. Michiels

3. KNOKKE-HEIST

Heist

Knokke

Ramskapelle

Westkapelle

4. MOERKERKE

Hoeke

Lapscheure

Moerkerike
GS

GVMP

10.199

3.178

1.4 .422

52.220

2.049

1.049

2.014

13.409

11.033

8.994

GMW

GVMP

GS

AK

GP

AK

$A G$

AK

209

560

2.953

27.582

5.696

5.6 .70

17.7 .70

$$
3.553 \quad 4.053
$$

$27 \cdot 5 \cdot 70$

17.7 .70

\section{Arrondissement DIKSMUIDE}

1. BEERST

Beerst

Keiem

1.215

AK

1.297

2. DRIEKAPELIEN

Nieuwkapelle

Oudekapelle

St. Jacobskapelle

AK

556

186

$A G$

151

3. KOEKELARE

Bovekerke

Koekelare

Zande

1.109

AK

6.372

GP

2.429

2.458

20.1 .70

$17.7 \cdot 70$

848

1.761

10.6 .69

17.7 .70

$A G$

7.807

3.918

$22.4 \cdot 70$

$17 \cdot 7 \cdot 70$

380

4. IO

Io

AK

1.172

Pollinkhove

AK

1.007

$$
1.926 \quad 2.950
$$

20.1 .70

$17 \cdot 7.70$

$$
1.648 \quad 3.344
$$

10.6 .69

$17 \cdot 7 \cdot 70$

1.339

Noordschote

AG

454

Reninge

$A G$

6. ZARREN-WERKEN 
Arrondj.ssement JTPER

1. BOEZINCE

Boezinge

Zuidschote

2. CELUVETD

Geluveld

Zandvoorde

3. IEPER

Brielen

Ieper

St. Jan

4. LANGEMARK

Bikschote

Langemork

5. PROVEN

Krombeke

Proven

6. ZILLEBEKE

Hollebeke

Voormezele

Zillebeke

Arrondissement KORTRIJK

1. ANZEGEM

Anzegen

Gijzelbre chtegem
AK

$A K$

1.887

418

VW

AK

1.567

707

$A K$

GS

$\mathrm{LH}$

AK

GP

7.11

4.686

AK

AK

909

1.534

LW

AK

GP

757

951

1.773

18.121

863

$20.825 \quad 2.870$

12.3 .70

17.7 .70

$2.185 \quad 1.446$

16.6 .70

17.7 .70

23.3 .70 17.7 .70

5.457

3.608

20.1 .70

17.7 .70

$2.273 \quad 2.164$

5.6 .70

17.7 .70

3.613

3.465

16.6 .70

17.7 .70

4.681

1.696

$24 \cdot 12 \cdot 6$

4.122

247

17.7 .7

GVMIP

Moere

2. OOSTENDE

Oostende

Stene

Zandvoorde

3. SPERMAIIE

Mannekensvere

Schore

St. Pieterskapelle

slijpe

VW

5.789

$A G$

1.097

$A K$

713

RS

56.494

71.226

3.763

29.6 .70

$17 \cdot 7.70$

7.113

GMW

1.750

AG

AK

AK

239

8.063

3.277

20.1 .70

17.7 .70

AK

1.103
28.4 .70

$17 \cdot 7 \cdot 70$ 
4. WESTENDE

Lombardszijde

GMN

1.424

4.854

1.080

12.3 .70

Westende

GVMP

2.4 .15

17.7 .70

Arrondissement VEURNE

1. ALVERINGEM

Alveringem

AK

Hoogstade

AK

$A G$

Oeren

St. Rijkers

$A G$

1.964

2.451

3.125

10.6 .69

17.7 .70

2. BEAUVOORDE

Vinkem

$A G$

450

76

184

Wulveringem

416

898

1.464

20.1 .70

AK

605

3. HOUTEM

De Moeren

AK

182

Hou tem

$A G$

1.030

4. LEISEIE

Gijverinkhove

AK

459

Izenberge

580

Leisele

AG

1.075

5. NIEUWPOORT

Nieuwpoort

Ramskapelie

GS

AK

6.899

708

St. Joris

AK

334

6. OOSTDUINKERKE

Oostduinkerke

GVMP

Wulpen

3.385

727

7. PERVIJZE

Lampernisse

AK

1.039

2.429

10.2 .70

$17 \cdot 7 \cdot 70$

Oostkerke

Pervijze

Stuivekenskerke

$A G$

269

336

AK

1.120

$\mathrm{AK}$
$\mathrm{AG}$

1.762

2.380

20.1 .70 17.7 .70

8. STAVELE

Beveren

Stavele

AK

$A G$

8.273

2.963

31.3 .70

17.7 .70

203

4.380

2.974

20.1 .70

$37.7 \cdot 70$

1.729

3.695

10.2 .70

17.7 .70

9. VEURNE

Avekapelle

LW

Booitshoeke

$A G$

Bulskamp.

Eggewaartskapelle

$A G$

150

Steenkerke

$A G$

697

Veurne

565

Zoutenaaie

$A G$

GS

1.818

2.497

20.1 .70

17.7 .70

953

9.496

5.736

5.6 .70

17.7 .70 
Bijlage 2

FNANCIELE GEGEVENS TER ONDERSTEUNING VAN

HET EVALUATIE-ONDERZOEK.

A. DIKSMJIDE, IZEGIMI, ROESEIARE

B. 30 West-Vlaamse fusiegemeenten

C. BRUGGE 
Bijlage 2 - A Finaneiële gegevens over do drie rust-Vlanmse fusiogumenten uit de exste fusiegoif: 1965

\section{DIKSMUIDE - IZEGEM - BUMARE}

DIKSiUIDE : Inkomsten en uitgaven per inwoner in Dil.waide vobr en na de fusie (giwone rekeningen 1964-1972).

\begin{tabular}{|c|c|c|c|c|c|c|}
\hline & \multicolumn{3}{|c|}{ Total eigen ciunstjaar } & \multicolumn{3}{|c|}{ Algenecn totaal } \\
\hline & $\begin{array}{l}\text { Vastgest. } \\
\text { rechten }\end{array}$ & $\begin{array}{l}\text { Vastgest. } \\
\text { uitgaven }\end{array}$ & $\begin{array}{l}\text { pos. of } \\
\text { neg. saldd }\end{array}$ & $\begin{array}{l}\text { Vastgest. } \\
\text { rechten }\end{array}$ & $\begin{array}{l}\text { Vastgest. } \\
\text { uitgaven }\end{array}$ & $\begin{array}{l}\text { pos. of } \\
\text { neg. saldo }\end{array}$ \\
\hline 1964 & & & & & & \\
\hline Kaaskerke & $1.506,5$ & $1.185,8$ & $+320,7$ & $1.793,7$ & 1.602 .9 & 9,9 \\
\hline Esen & $1.311,2$ & $1.352,5$ & $-41,3$ & $1.725,0$ & $1.451,3$ & $+273,7$ \\
\hline Diksmuide & 1. 458,0 & $1.498,4$ & $-60,0$ & $1.634,4$ & $1.632,9$ & 1,5 \\
\hline Diksnuide & $1.418,9$ & $1.428,4$ & $-9,5$ & $1.674,8$ & $1.576,8$ & 98,0 \\
\hline Diksmuide & & & & & & \\
\hline 1965 & $1.619,9$ & $1.751,3$ & $-\quad 68,7$ & $1.819,8$ & $1.827,6$ & 7,7 \\
\hline 1966 & $1.983,7$ & $1.941,2$ & $+\quad 42,5$ & $2.211,7$ & $2.175,8$ & 35,8 \\
\hline 1967 & $2.142,2$ & $1.987,8$ & $+154,3$ & $2.312,6$ & $2.209,9$ & $+102,6$ \\
\hline 1968 & $2.528,7$ & $2.386,6$ & $+142,1$ & $2.626,0$ & $2.463,1$ & $+162,9$ \\
\hline 1969 & $2.644,5$ & $2.413,4$ & $+231,1$ & $2.961,1$ & $2.546,3$ & $+414,8$ \\
\hline 1970 & $2.927,6$ & $2.789,3$ & $+\quad 138,2$ & $3.379,5$ & $2.821,2$ & $+558,3$ \\
\hline 1971 & $3.235,5$ & $3.483,3$ & $-\quad 247,7$ & $3.873,2$ & $3.627,5$ & $+245,7$ \\
\hline 1972 & $4.160,8$ & $4.174,3$ & $-\quad 13,4$ & $4.475,2$ & $4.287,0$ & $+\quad 188,2$ \\
\hline
\end{tabular}

Bron: Provinciale diensten West-Vlaanderen 


\begin{tabular}{|c|c|c|c|c|c|c|c|c|}
\hline \multirow{3}{*}{ Uitgaveposten } & \multicolumn{4}{|c|}{ vỏsr fusie } & \multicolumn{4}{|c|}{ na fusic } \\
\hline & \multicolumn{4}{|c|}{1964} & \multicolumn{4}{|c|}{ DIKSMUIDE } \\
\hline & Kaaskerke & Esen & Diksmuide & $\begin{array}{l}\text { Groot } \\
\text { Diksmuide }\end{array}$ & 1965 & 1966 & 1967 & 1968 \\
\hline Gumuentelijk patrimonium & 16,87 & 27,24 & 23,45 & 24,01 & 22,22 & 37,21 & 27,65 & 50,49 \\
\hline Agumene administratio & 353,53 & 195,69 & 282,59 & 263,10 & 272,97 & 281,98 & 285,13 & 313,83 \\
\hline Politie-veiligheic-branỏwer & 201,55 & 72,47 & 178,73 & 138,74 & 168,23 & 185,27 & 208,10 & 219,34 \\
\hline $\begin{array}{l}\text { Gmecntebedrijuen en daamee } \\
\text { geijikgestelde dicnsten }\end{array}$ & - & - & - & - & - & - & - & - \\
\hline $\begin{array}{l}\text { pponbare ondexstand an } \\
\text { patschapplijke voorzorg }\end{array}$ & 6,14 & 58,13 & 10,19 & 23,99 & 30,31 & 19,51 & 19,08 & 90,47 \\
\hline opcnbare gezondheid & 34,41 & 11,74 & 66,20 & 47,41 & 38,65 & 51,91 & 63,33 & 91,47 \\
\hline Wegen en Openivare Werken & 67,15 & 123,76 & 279,83 & 215,48 & 206,49 & 267,47 & 248,36 & 288,79 \\
\hline Crodienst & 12,07 & 13,22 & 16,38 & 15,03 & 18,44 & 22,85 & 34,69 & 43,09 \\
\hline londervijs & 36,10 & 323,78 & 28,05 & 115,91 & 192,73 & 238,63 & 237,02 & 300,38 \\
\hline $\begin{array}{l}\text { Schone kunstcn-volksopleicing- } \\
\text { ontepanning-folklore }\end{array}$ & 12,41 & 48,37 & 110,44 & 84,35 & 84,16 & 117,49 & 100,69 & 149,53 \\
\hline Pusioenen en lastun & 34,66 & 47,31 & 119,28 & 95,08 & 123,43 & 135,26 & 144,47 & 161,21 \\
\hline Schuld & 716,58 & 424,38 & 383,12 & 424,04 & 472,54 & 583,60 & 619,32 & 678,02 \\
\hline Powdrachten & - & 5,85 & - & 1,72 & - & - & - & - \\
\hline LOTAAL & $1.185,85$ & $2.352,66$ & $1.493,44$ & $2.423,48$ & $1.751,37$ & $1.941,22$ & $1.987,89$ & $2.386,66$ \\
\hline
\end{tabular}


Vontilatio der uitgaven uitgedrukt per inwoner, voor de fusicgenente DILSTUIDE. $\quad 1969-1972$

Gewone Dienst

\begin{tabular}{|c|c|c|c|c|}
\hline Uitgareposten & 1969 & 1970 & 1971 & 1972 \\
\hline Algemen & 3,88 & 3,40 & 9,52 & 7,95 \\
\hline Algemane: schuld & 3,78 & 3,78 & 3,86 & 3,76 \\
\hline Fondsen & - & - & - & - \\
\hline Belastingen cn retributics & - & - & 0,04 & - \\
\hline Verzekeringun & 4,39 & 4,95 & 4,22 & 7,98 \\
\hline Algemene administratic & 359,21 & 403,57 & 521,17 & 571,37 \\
\hline Privaat patrinonim & 30,99 & 30,33 & 42,19 & 47,00 \\
\hline Algemene diunsten & - & - & - & - \\
\hline Justitic-politie & 224,35 & 239,05 & 275,74 & 332,23 \\
\hline Brandweer & 57,47 & 40,32 & 75,59 & 78,60 \\
\hline Verkeer-wegen-waterjopen & 553,46 & 669,20 & 912,18 & $1.011,53$ \\
\hline Hande 1-nijverhoid & 235,05 & 239,09 & 257,99 & 257,30 \\
\hline Landbouw & 3,53 & 3,53 & 4,36 & 4,26 \\
\hline Rleuter en lager onderwijs & 239,67 & 239,37 & 246,70 & 242,68 \\
\hline $\begin{array}{l}\text { Middelbaar, nomaal en } \\
\text { technisch ondurwijs }\end{array}$ & 0,14 & 0,14 & 0,15 & \\
\hline Kunstonderwijs & 126,67 & 135,18 & 172,11 & 209,85 \\
\hline Hoger onderwijs & 0,22 & 0,22 & 0,22 & 0,07 \\
\hline Volksontwikkeling on küst & 215,92 & 386,54 & 389,78 & 470,36 \\
\hline Eredienst & 47,44 & 50,77 & 77,37 & 81,42 \\
\hline $\begin{array}{l}\text { Sociale voorzorg en } \\
\text { onderstand }\end{array}$ & 0,68 & 1,40 & 123,20 & 249,52 \\
\hline Sociale hulp & 14,18 & 14,96 & 16,80 & 20,41 \\
\hline Gezondheidszorg & 279,09 & 1,76 & 1,05 & 5,01 \\
\hline Openbare Hygiëne & & 298,14 & 367,31 & 572,96 \\
\hline Huisvesting-Stcdebouw & 1,62 & 10,58 & 10,76 & 14,68 \\
\hline TOTAAL & $2.413,48$ & $2.789,38$ & 483,31 & $4.174,34$ \\
\hline
\end{tabular}

Bron: Provinciale diensten 
IZEGES : Inkomsten on uitgevon per inwoner in Izegem vodr on na de fusie (gewone rokuningen 1964-1971).

\begin{tabular}{|c|c|c|c|c|c|c|}
\hline & \multicolumn{3}{|c|}{ Toraal eisen dienstjaar } & \multicolumn{3}{|c|}{ Algoneen Totaal } \\
\hline & $\begin{array}{l}\text { Vastgest. } \\
\text { rechten }\end{array}$ & $\begin{array}{l}\text { Vastgest. } \\
\text { uitgaven }\end{array}$ & $\begin{array}{ll}\text { pos. } & \text { of } \\
\text { neg. } & \text { saldo }\end{array}$ & $\begin{array}{l}\text { Vastgest. } \\
\text { ruchten }\end{array}$ & $\begin{array}{l}\text { Vastgest. } \\
\text { uitgaven }\end{array}$ & $\begin{array}{l}\text { pos. of } \\
\text { neg. sa1do }\end{array}$ \\
\hline 1964 & & & & & & \\
\hline teme $1 \mathrm{gem}$ & 774,3 & 632,6 & $+141,7$ & $1.000,4$ & 722,3 & 278,0 \\
\hline $\mathrm{Iz} \in g \subset \mathrm{n}$ & $1.695,3$ & $1.634,7$ & $+60,6$ & $2.052,8$ & $1.804,7$ & 248,0 \\
\hline izegem & $1.487,6$ & $1.408,7$ & $+\quad 73,8$ & $1.315,5$ & $1.560,6$ & 254,8 \\
\hline Izegem & & & & & & \\
\hline 1965 & $1.668,5$ & $1.251,9$ & $+416,6$ & $1.980,0$ & $1.382,1$ & 605,9 \\
\hline 1966 & $1.875,6$ & $1.827,0$ & $+\quad 48,6$ & $2.133,3$ & $1.974,3$ & 158,9 \\
\hline 1967 & $2.047,8$ & $2.047,9$ & 0,1 & $2.403,8$ & $2.266,5$ & 137,3 \\
\hline 1968 & $2.759,3$ & $2.269,9$ & $+489,3$ & $3.215,3$ & $2.699,3$ & 516,0 \\
\hline 1969 & $2.718,8$ & $2.368,1$ & $+350,6$ & $3.303,6$ & $2.583,0$ & 720,5 \\
\hline 1970 & $3.216,6$ & $2.888,7$ & $+\quad 327,9$ & $3.939,1$ & $2.922,4$ & $+1.016,6$ \\
\hline 1971 & $3.364,1$ & $3.492,8$ & $-\quad 128,7$ & $4.386,4$ & $3.689,4$ & 696,9 \\
\hline
\end{tabular}

Bron: Provinciale diensten West-Vlaanderen 


\begin{tabular}{|c|c|c|c|c|c|c|c|}
\hline \multirow{3}{*}{ Uitgaveposten } & \multicolumn{3}{|c|}{ Vỏor f̊usic } & \multicolumn{4}{|c|}{$\mathrm{Na}$ fusie } \\
\hline & \multicolumn{3}{|c|}{1864} & \multicolumn{4}{|c|}{ IZEGEM } \\
\hline & Emclgem & Izcgem & $\begin{array}{l}\text { Groot } \\
\text { Izegem }\end{array}$ & 1965 & 1966 & 1967 & 1968 \\
\hline Gemeentelijk patrimonium & 12,05 & 46,18 & 38,49 & 54,90 & 74,07 & 70,19 & 62,37 \\
\hline Agemeno administratic & 132,86 & 188,99 & 176,33 & 198,09 & 179,45 & 199,86 & 219,40 \\
\hline Politie-veilighcid-brançucer & 33,09 & 233,73 & 192,34 & 212,47 & 233,70 & 247,24 & 263,61 \\
\hline $\begin{array}{l}\text { Cementcbedrijven en daamee } \\
\text { gelijkgestcide diensten }\end{array}$ & - & 5,37 & 4,55 & 4,36 & 9,21 & 5,73 & 6,32 \\
\hline $\begin{array}{l}\text { openbare onderstand en } \\
\text { maatschappelijkc voorzorg }\end{array}$ & 81,23 & 276,15 & 233,20 & 224,01 & 244,87 & 266,25 & 288,59 \\
\hline openbare gezondheid & 5,88 & 63,54 & 50,58 & 62,78 & 74,62 & 101,08 & 97,85 \\
\hline Wegen en operbare werken & 113,07 & 179,65 & 164,64 & 164,79 & 236,40 & 266,25 & 312,86 \\
\hline Erodicnst & 29,75 & 40,70 & 38,23 & 48,22 & 51,64 & 54,07 & 56,71 \\
\hline Onderwijs & 2,52 & 224,97 & $174,31$. & 219,82 & 237,21 & 273,30 & 290,23 \\
\hline $\begin{array}{l}\text { Schone Nunston-volksopleiding- } \\
\text { ontspanning-folklore }\end{array}$ & 13,37 & 58,85 & 48,60 & 56,69 & 71,47 & 61,72 & 73,00 \\
\hline punsiocnen cn lasten & 44,50 & 130,94 & 111,45 & 126,64 & 153,88 & 181,17 & 180,07 \\
\hline Schuld & 164,29 & 180,08 & 176,52 & 221,07 & 260,43 & 305,40 & 418,89 \\
\hline Overarachten & - & - & - & - & - & - & - \\
\hline TOTAAL & 632,62 & $1.634,78$ & $1.408,79$ & $1.593,90$ & $1.827,04$ & $2.047,93$ & $2.269,96$ \\
\hline
\end{tabular}


Ventilatic der ujtgaven, uitgudrukt per inwoner, voor de fusicgumente IZEGEY. $\quad$ 1969-1971

Gewone Dienst

\begin{tabular}{|c|c|c|c|}
\hline \multirow{2}{*}{ Uitgavoposten } & \multicolumn{3}{|c|}{ IZEGEP } \\
\hline & 1969 & 1970 & 1971 \\
\hline Algemeen & 0,84 & 1,03 & 2,53 \\
\hline h1etmene schuld & 10,02 & 9,80 & 9,20 \\
\hline fondsen & - & - & - \\
\hline Belastingen en retributies & - & 0,22 & 0,67 \\
\hline Ferzekeringun & 0,82 & 1,30 & 0,76 \\
\hline Algemenc administratic & 262,31 & 301,69 & 413,98 \\
\hline Privaat patrimoniun & 5,38 & 5,03 & 6,23 \\
\hline Algemene dicnsten & 0,26 & 0,17 & - \\
\hline Justitia-politie & 326,65 & 339,78 & 388,78 \\
\hline Brandweer & 34,34 & 35,93 & 74,53 \\
\hline Nerkeer-wegen-waterwegen & 640,25 & 978,74 & $1.035,54$ \\
\hline lande1-ni.jverheid & 8,17 & 7,10 & 4,96 \\
\hline Landbouw & 0,39 & 0,39 & 0,38 \\
\hline kleuter- on lagcronderwijs & 61,82 & 67,67 & 76,42 \\
\hline $\begin{array}{l}\text { Iiddelbaar, normaal en } \\
\text { technisch onderwijs }\end{array}$ & 65,70 & 87,20 & 146,08 \\
\hline Kunstonderwijs & 224,47 & 266,05 & 323,29 \\
\hline Hoger onderwijs & - & - & - \\
\hline Volksontwikkeling en kunst & 125,73 & 158,35 & 169,64 \\
\hline Eredicnst & 97,94 & 84,42 & 100,73 \\
\hline Socialc voorzorg en onderstand & 181,00 & 196,18 & 331,97 \\
\hline Sociale hulp & 28,04 & 27,55 & 40,56 \\
\hline Gezondheidszorg & 244,48 & 1,98 & 1,46 \\
\hline Openbare hygiëne & 244,48 & 245,21 & 268,07 \\
\hline Huisvesting-stedebouw & 48,97 & 71,98 & 90,73 \\
\hline TOTAAL & $2.368,15$ & $2.888,73$ & $3.486,34$ \\
\hline
\end{tabular}

Bron: Provinciale diensten 
ROESELARE: Inkonsten un ujtgaven per inwoner in Roselare vobre en na de fusie (gewone rokuningun 2964-1972).

\begin{tabular}{|c|c|c|c|c|c|c|}
\hline & \multicolumn{3}{|c|}{ Totar1 digen dionstjaar } & \multicolumn{3}{|c|}{ Algeneen Totaal } \\
\hline & $\begin{array}{l}\text { Vastgost. } \\
\text { rechtor. }\end{array}$ & $\begin{array}{l}\text { Vastgest. } \\
\text { uitgaven }\end{array}$ & $\begin{array}{l}\text { pos. of } \\
\text { neg. saldo }\end{array}$ & $\begin{array}{l}\text { Vastgust. } \\
\text { rechton }\end{array}$ & $\begin{array}{l}\text { Vastgest. } \\
\text { uitgavon }\end{array}$ & $\begin{array}{l}\text { pos. of } \\
\text { neg. saldo }\end{array}$ \\
\hline 1964 & & & & & & \\
\hline Buveren & $2.533,7$ & $2.625,6$ & $-91,915$ & $2.843,9$ & $2.716,1$ & $+\quad 127,8$ \\
\hline Roesulare & 2.470 .0 & $2.369,9$ & $+100,100$ & $3.026,4$ & $2.807,5$ & $+218,9$ \\
\hline Rocselare & $2.475,3$ & 2.399 .1 & $+82,683$ & $3.009,9$ & $2.552,8$ & $+199,0$ \\
\hline Roesclare & & & & & & \\
\hline 1965 & $2.244,7$ & $2.397,3$ & $-152,675$ & $2.795,6$ & $2.752,5$ & 43,0 \\
\hline 1966 & 2.870 .4 & $2.610,2$ & $+260,277$ & $3.352,3$ & $3.045,5$ & $+306,7$ \\
\hline 1967 & $2.949,1$ & $2.920,5$ & $+23,608$ & $3.560,0$ & $3.149,1$ & $+418,3$ \\
\hline 1968 & $3.432,3$ & $3.350,5$ & +82.227 & 3.842 .4 & $3.524,5$ & $+317,9$ \\
\hline 1969 & $3.657,1$ & $3.641,3$ & $+15,793$ & $4.427,9$ & $3.895,1$ & $+532,8$ \\
\hline 1970 & $4.178,3$ & $4.004,6$ & $+173,629$ & $4.940,4$ & $4.188,4$ & $+751,9$ \\
\hline 1971 & $4.807,3$ & $4.679,9$ & $+127,402$ & $5.695,9$ & $4.973,8$ & $+722,1$ \\
\hline 1972 & $5.300,5$ & $5.584,9$ & $-284,345$ & $6.196,8$ & $5.372,6$ & $+\quad 324,2$ \\
\hline
\end{tabular}

Bron: Provinciale dicnsten West Vlaanderen 


\begin{tabular}{|c|c|c|c|c|c|c|c|}
\hline \multirow{2}{*}{ Uitgaveposten } & \multicolumn{3}{|c|}{ Vobr fusio } & \multicolumn{4}{|c|}{ Na fusie } \\
\hline & Beveren & Rocsclard & $\begin{array}{l}\text { Groot } \\
\text { Roesclare }\end{array}$ & 1965 & 1966 & 1967 & 1968 \\
\hline Gemeentclijk patrimonium & 12,60 & 39,82 & 37,35 & 53,37 & 29,24 & 84,23 & 81,74 \\
\hline Agunenc administratio & 227,47 & 168,70 & 174,03 & 186,00 & 192,04 & 222,14 & 238,89 \\
\hline $\begin{array}{l}\text { Comentubedrijvon en } \\
\text { daamed gulijkgestolde } \\
\text { dicnston }\end{array}$ & - & - & - & - & 15,86 & 18,90 & 25,52 \\
\hline $\begin{array}{l}\text { pponbare onderstand en } \\
\text { matschanpelijke voorzorg }\end{array}$ & 70,30 & 426,27 & 393,98 & 269,97 & 242,85 & 278,66 & 379,57 \\
\hline Openbare gezondheid & 28,08 & 101,64 & 94,97 & 103,91 & 99,01 & 117,88 & 127,10 \\
\hline $\begin{array}{l}\text { Schore kunsten-volksopleiding- } \\
\text { ontspanning-folklore }\end{array}$ & 47,07 & 53,83 & 53,22 & 42,66 & 49,26 & 59,29 & 60,16 \\
\hline Pensioenen on lasten & 53,48 & 143,35 & 135,20 & 175,00 & 203,84 & 235,66 & 238,85 \\
\hline Schuld & 676,33 & 420,01 & 443,26 & 513,75 & 581,99 & 613,80 & 739,25 \\
\hline Overdrachten & $1.225,70$ & & & & & & \\
\hline TOTAAL & $2.625,69$ & $2.369,97$ & $2.393,16$ & $2.397,38$ & $2.610,21$ & $2.920,59$ & $3.350,58$ \\
\hline
\end{tabular}

Bron: Provinciale diensten 
Ventilatio der uitgaven, uitgedrukt per inwoner, voor de fusiegwitente Rocselare. 1969-1972

Giwone Dienst

\begin{tabular}{|c|c|c|c|c|}
\hline \multirow{2}{*}{ Uitgaveposten } & \multicolumn{4}{|c|}{ ROESELARE } \\
\hline & 1969 & 1970 & 1971 & 1972 \\
\hline Algemeen & 10,97 & 10,93 & 34,60 & 37,79 \\
\hline Algemenc schuld & 29,07 & 28,99 & 29,09 & 28,62 \\
\hline Fondsen & - & - & - & - \\
\hline Bclastingon on retributics & 5,01 & 3,37 & 2,70 & 3,93 \\
\hline Verzckeringen & 3,45 & 3,45 & 3,47 & 3,87 \\
\hline Algemene administratie & 376,01 & 309,62 & 407,25 & 459,38 \\
\hline Privaat patrimonium & 17,84 & 17,66 & 19,78 & 18,96 \\
\hline Algcmone diensten & 0,96 & 80,15 & 97,29 & 111,35 \\
\hline Justitie-politie & 499,81 & 535,43 & 609,71 & 697,43 \\
\hline Brandweer & 46,13 & 44,25 & 53,99 & 107,60 \\
\hline Verkecr-wegcn-waterlopen & 348,92 & $1.065,94$ & $1.201,01$ & $1.337,44$ \\
\hline Hande1-nijvorheid & 84,08 & 102,18 & 111,78 & 123,71 \\
\hline Landbouw & 1,26 & 1,12 & 6,91 & 10,75 \\
\hline Kleuter-en lager onderwijs & 225,50 & 234,21 & $2.51,50$ & 291,64 \\
\hline $\begin{array}{l}\text { Middulbaar, normal en } \\
\text { technisch onderwijs }\end{array}$ & 83,25 & 87,53 & 100,00 & 127,47 \\
\hline Kunstonderwijs & 326,20 & 365,72 & 431,76 & 562,51 \\
\hline Hoger onderwijs & 0,04 & 0,04 & 0,04 & 0,04 \\
\hline Volksontwikkeling en kunst & 146,16 & 204,31 & 297,55 & 383,08 \\
\hline Eredienst & 86,26 & 99,37 & 105,06 & 118,98 \\
\hline $\begin{array}{l}\text { Sociale voorzorg en } \\
\text { onderstand }\end{array}$ & 342,07 & 289,12 & 302,45 & 414,10 \\
\hline Sociale hulp & 15,39 & 19,59 & 24,00 & 25,81 \\
\hline Gezondheidszorg & 399,47 & 58,45 & 62,92 & 76,05 \\
\hline Openbare hygiëne & - & 419,13 & 477,09 & 585,63 \\
\hline Huisvesting en stedebouw & 93,42 & 48,65 & 44,92 & 61,64 \\
\hline TOTAAL & $3.641,36$ & $4.004,67$ & $4.679,97$ & $5.584,90$ \\
\hline
\end{tabular}

Bron: Provinciale diensten 


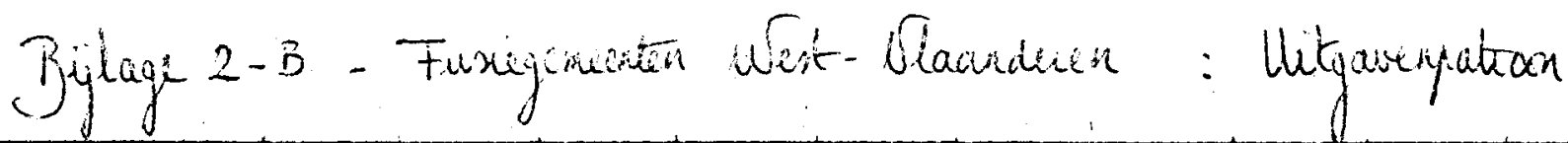

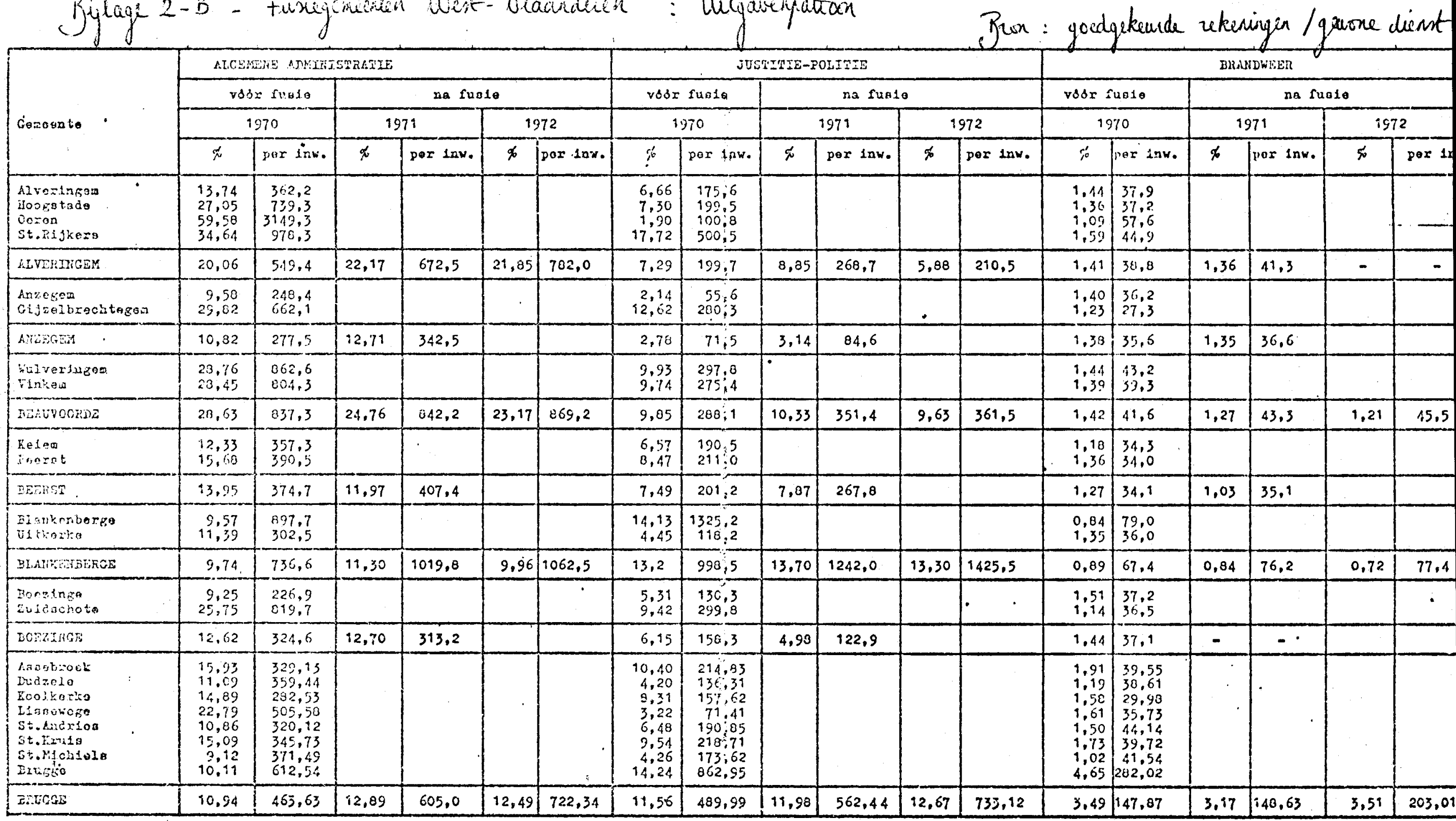




\begin{tabular}{|c|c|c|c|c|c|c|c|c|c|c|c|c|c|c|c|c|c|c|}
\hline \multirow{4}{*}{ Gevento } & \multicolumn{6}{|c|}{ DKAKEIRR - WEGET - WATREIORES } & \multicolumn{6}{|c|}{ KLEOTER - BN LAGER OMDHRWIJS } & \multicolumn{6}{|c|}{ VERZORCENDE TARTSN } \\
\hline & \multirow{2}{*}{\multicolumn{2}{|c|}{$\frac{\text { vosr fuase }}{1970}$}} & \multicolumn{4}{|c|}{ na fugio } & \multirow{2}{*}{\multicolumn{2}{|c|}{$\frac{\text { vośr rusio }}{1970}$}} & \multicolumn{4}{|c|}{ na fualo } & \multirow{2}{*}{\multicolumn{2}{|c|}{$\frac{\text { rodx fusio }}{1970}$}} & \multicolumn{4}{|c|}{ ne rualo } \\
\hline & & & \multicolumn{2}{|c|}{1971} & \multicolumn{2}{|c|}{1972} & & & \multicolumn{2}{|c|}{1971} & \multicolumn{2}{|c|}{1972} & & & \multicolumn{2}{|c|}{1971} & \multicolumn{2}{|c|}{1972} \\
\hline & $\%$ & per fnw. & $\%$ & por inw. & $\approx$ & per inw. & $\%$ & pex in. & $\%$ & por lnw. & $\check{\alpha}$ & por inv. & $\not \phi$ & por jnw. & $\not$ & par inw. & $\mathscr{\%}$ & per ins: \\
\hline 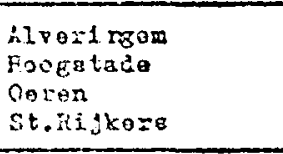 & $\begin{array}{l}42,94 \\
36,78 \\
29,47 \\
30,40 \\
\end{array}$ & $\begin{array}{l}1131,4 \\
1004,8 \\
1558,0 \\
1084,2 \\
\end{array}$ & & $\cdot$ & & & $\begin{array}{r}20,09 \\
13,12 \\
0,84 \\
0,66 \\
\end{array}$ & $\begin{array}{r}529,3 \\
495,3 \\
44,5 \\
18,8 \\
\end{array}$ & 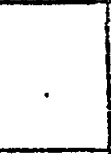 & . & • & & $\begin{array}{r}13,10 \\
7,71 \\
5,89 \\
5,91 \\
\end{array}$ & $\begin{array}{l}345,0 \\
210,5 \\
311,2 \\
166,7 \\
\end{array}$ & & & & \\
\hline ALVEATHEM & 40,70 & 1116,8 & 40,03 & 1214,4 & 40,74 & 1458,4 & 17,36 & 475,5 & 14,47 & 438,9 & 18,76 & 671,5 & 11,24 & 307,5 & 10,82 & 328,0 & 10 & $37 \%, 9$ \\
\hline $\begin{array}{l}\text { Anzezan } \\
\text { GLJzeluzeoh togom }\end{array}$ & $\begin{array}{l}63,35 \\
49,66 \\
\end{array}$ & $\begin{array}{l}1641,4 \\
1102,5 \\
\end{array}$ & & & & & $\begin{array}{l}1,37 \\
0,69 \\
\end{array}$ & $\begin{array}{l}35,7 \\
15.4 \\
\end{array}$ & & r & & - & $\begin{array}{r}20,97 \\
3,40 \\
\end{array}$ & $\begin{array}{r}543,2 \\
75,5 \\
\end{array}$ & & & & \\
\hline AREABA & 62,51 & 1603.4 & 57,76 & 1556,0 & & & 1,33 & 34,3 & 0,30 & 8,2 & & & 19,90 & 510,2 & 21,91 & . 600,4 & & \\
\hline $\begin{array}{l}\text { Vulvoridgen } \\
\text { Vinked }\end{array}$ & $\begin{array}{l}27,49 \\
27,46 \\
\end{array}$ & $\begin{array}{l}824,5 \\
776,3 \\
\end{array}$ & & & & - & $\begin{array}{l}12,67 \\
17,50 \\
\end{array}$ & $\begin{array}{l}380,2 \\
494,7 \\
\end{array}$ & & & & & $\begin{array}{l}12,37 \\
12,86 \\
\end{array}$ & $\begin{array}{l}270,8 \\
363,4 \\
\end{array}$ & $\dot{.}$ & & & \\
\hline TEATYOCRES & 27,48 & 803,6 & 26,62 & 905,5 & 27,60 & 1035,3 & 14,69 & 429,8 & 13,57 & 461,6 & 12,89 & 483,6 & 12,58 & $3 \in 7,7$ & 14,44 & 490,6 & 15,16 & 568,1 \\
\hline $\begin{array}{l}\text { Iecret } \\
\text { Ieien }\end{array}$ & $\begin{array}{l}32,90 \\
31,43 \\
\end{array}$ & $\begin{array}{l}955,9 \\
782,8 \\
\end{array}$ & & & & & $\begin{array}{l}32,94 \\
16,76 \\
\end{array}$ & $\begin{array}{l}954 ; 7 \\
417 ; 6 \\
\end{array}$ & & - & & & $\begin{array}{l}11,92 \\
20,30 \\
\end{array}$ & $\begin{array}{l}345,5 \\
403,8 \\
\end{array}$ & & & & \\
\hline DEMen & $3,2,22$ & 865,4 & 41,55 & 1413,2 & & & 25,10 & 674,0 & 22,53 & 766,2 & & & 15,93 & 423,1 & 11,83 & $40 ? .1$ & & \\
\hline $\begin{array}{l}\text { Elankenbsiza } \\
\text { El tisere }\end{array}$ & $\begin{array}{l}10,46 \\
19,13 \\
\end{array}$ & $\begin{array}{l}980,3 \\
509,4 \\
\end{array}$ & & & & & $\begin{array}{r}8,27 \\
1,22 \\
\end{array}$ & $\begin{array}{r}775,7 \\
32,5 \\
\end{array}$ & & & & & $\begin{array}{l}48,47 \\
54,70 \\
\end{array}$ & $\begin{array}{r}4542,9 \\
1452,2 \\
\end{array}$ & & & & \\
\hline BIARKEHTERGE & 11,2 & 853,2 & 10,9 & 990.7 & 10,7 & 1141.5 & 7,60 & 574,5 & 1,06 & 95.5 & 0,41 & 44,0 & 49,0 & 3706.5 & 48,9 & 4412,0 & 48,7 & 5997,7 \\
\hline $\begin{array}{l}\text { Ronzinge } \\
\text { zuddaciato }\end{array}$ & $\begin{array}{l}59.52 \\
39,61 \\
\end{array}$ & $\begin{array}{l}1459,5 \\
1261,0 \\
\end{array}$ & & & & & $\begin{array}{l}0,20 \\
0,03 \\
\end{array}$ & $\begin{array}{l}4 \% 9 \\
1,0 \\
\end{array}$ & & & & & $\begin{array}{l}16,20 \\
15,30 \\
\end{array}$ & $\begin{array}{r}397,1 \\
486,9 \\
\end{array}$ & & & & \\
\hline BOLZTRGE & 55.46 & 1426.8 & 59.51 & 1467.0 & & & 0,16 & $4: 2$ & 0,31 & 7.7 & & & 16,02 & 411,8 & 17.64 & 671,2 & & \\
\hline 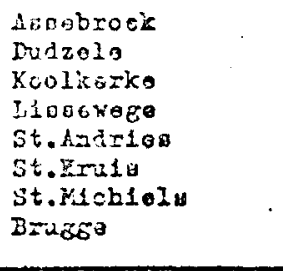 & $\begin{array}{r}28,48 \\
46,55 \\
9,72 \\
27,25 \\
2, ., 31 \\
38,54 \\
20,39 \\
15,95\end{array}$ & $\begin{array}{r}589,38 \\
1522,10 \\
184,31 \\
604,52 \\
731,31 \\
883,29 \\
830,57 \\
845,94\end{array}$ & & & & & $\begin{array}{r}0,60 \\
14,35 \\
30,43 \\
21,40 \\
7,22 \\
0,67 \\
10,40 \\
1,58\end{array}$ & $\begin{array}{r}12,40 \\
465,08 \\
577,51 \\
474,77 \\
212,75 \\
15,38 \\
423,46 \\
96,40\end{array}$ & $\cdot$ & . & & & $\begin{array}{l}40,03 \\
19,49 \\
32,23 \\
18,46 \\
43,62 \\
33,00 \\
36,45 \\
38,08\end{array}$ & $\begin{array}{r}843,78 \\
631,82 \\
619,64 \\
409,90 \\
1285,46 \\
756,18 \\
1484,67 \\
2308,30\end{array}$ & & . & & - \\
\hline 2UDJGGE & 18,76 & 795.37 & 18,03 & 846,41 & 16,34 & 945.48 & 3.55 & 150,40 & 4,17 & 195,60 & 4,33 & 250,46 & 37,82 & 1603,24 & 35.35 & 1659.59 & 37.26 & 2155.4 \\
\hline
\end{tabular}




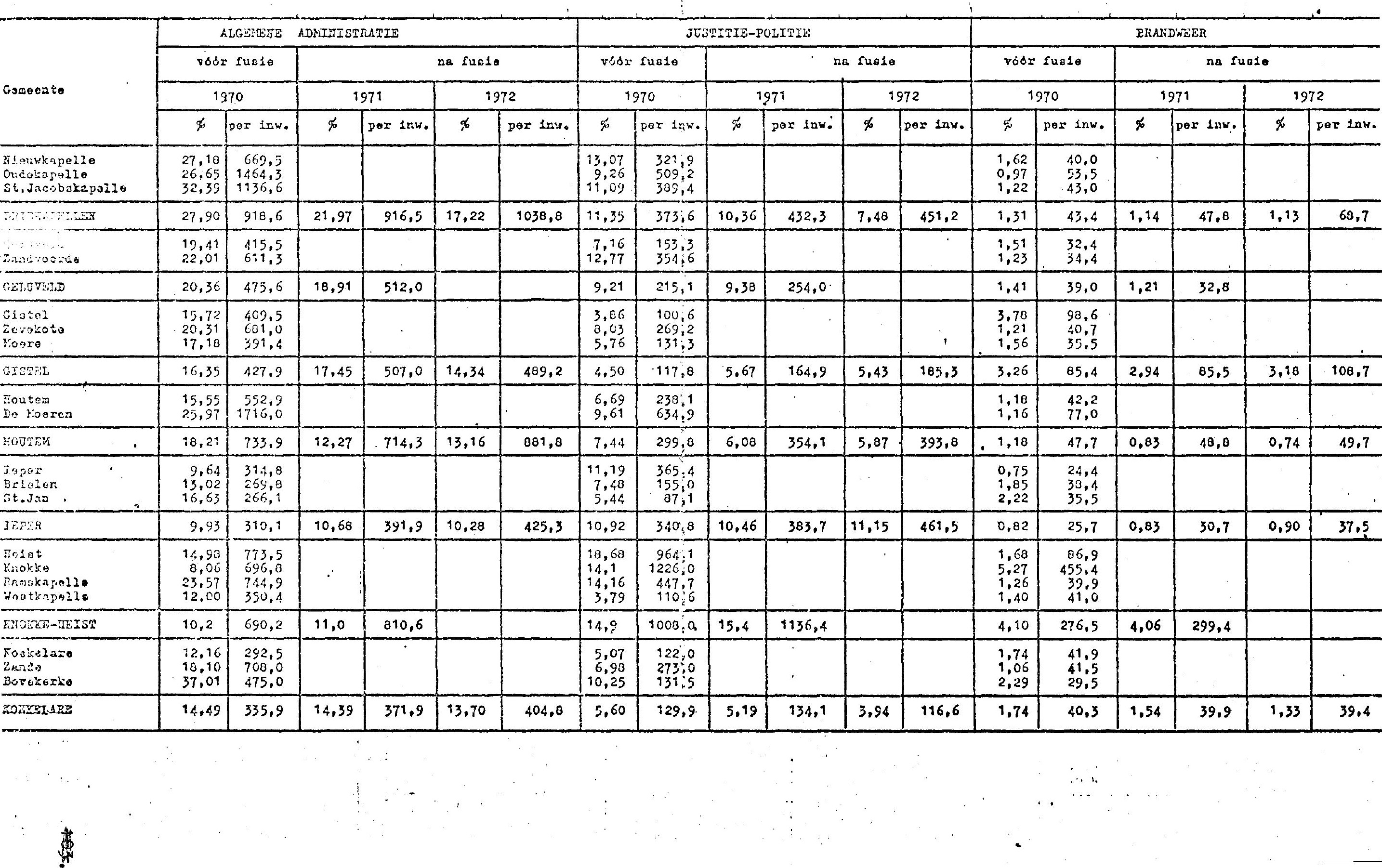




\begin{tabular}{|c|c|c|c|c|c|c|c|c|c|c|c|c|c|c|c|c|c|c|}
\hline \multirow{4}{*}{ Gomanto } & \multicolumn{6}{|c|}{ VERYKEF - WEGNA - WATRRIGPEN } & \multicolumn{6}{|c|}{ KITUTRK- EN LAGER OHDERKIJS } & \multicolumn{6}{|c|}{ VTRZORGENDE I'AKTN } \\
\hline & \multirow{2}{*}{\multicolumn{2}{|c|}{$\frac{\text { vosr fuzio }}{1970}$}} & \multicolumn{4}{|c|}{$\mathrm{na}$ fusio } & \multirow{2}{*}{\multicolumn{2}{|c|}{$\frac{\text { vós }=\text { fusio }}{1970}$}} & \multicolumn{4}{|c|}{ na furio } & \multirow{2}{*}{\multicolumn{2}{|c|}{$\frac{\text { vodr fusio }}{1970}$}} & \multicolumn{4}{|c|}{ na fusie } \\
\hline & & & \multicolumn{2}{|c|}{1971} & \multicolumn{2}{|c|}{1972} & & & \multicolumn{2}{|c|}{1971} & \multicolumn{2}{|c|}{1972} & & & \multicolumn{2}{|c|}{1971} & \multicolumn{2}{|c|}{1972} \\
\hline & $\%$ & per lriw. & $\mathscr{q}$ & por Ins. & $\stackrel{p}{p}$ & par ins. & $\%$ & por inw. & $\not x$ & per lnw. & 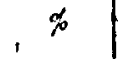 & pex 1nw. & $\%$ & por Inw. & 86 & per lnw. & $\%$ & por lan \\
\hline $\begin{array}{l}\text { Nlouwkapelio } \\
\text { Oudekrpallo } \\
\text { St.Jecobstapello }\end{array}$ & $\begin{array}{r}29,37 \\
28,29 \\
3,58 \\
\end{array}$ & $\begin{array}{r}738,4 \\
1554,4 \\
125,8 \\
\end{array}$ & & & & & $\begin{array}{l}13,67 \\
17,59 \\
35,79 \\
\end{array}$ & $\begin{array}{r}465,0 \\
966,8 \\
1256,0 \\
\end{array}$ & & & & & $\begin{array}{r}8,66 \\
13,80 \\
14,36 \\
\end{array}$ & $\begin{array}{l}213,2 \\
758,5 \\
503,7 \\
\end{array}$ & & & & \\
\hline DRIFXAFELESX & 24,71 & 813,4 & 21,92 & 914,3 & 16,80 & 1013,8 & 21,40 & 704,4 & $1.4,71$ & 613,7 & 10,85 & 654,8 & 15,52 & 379,0 & 24,25 & 1011,1 & 40,50 & 2697.1 \\
\hline $\begin{array}{l}\text { Celuveld } \\
\text { zandroorde }\end{array}$ & $\begin{array}{l}30,99 \\
34,00 \\
\end{array}$ & $\begin{array}{l}633,4 \\
944,2 \\
\end{array}$ & & & & & $\begin{array}{l}19,02 \\
24,01 \\
\end{array}$ & $\begin{array}{l}407,1 \\
666,6 \\
\end{array}$ & & & & & $\begin{array}{r}20,23 \\
5,46 \\
\end{array}$ & $\begin{array}{l}432,0 \\
151,5 \\
\end{array}$ & & & & \\
\hline CELUVETD & 32,09 & 749,5 & 33,30 & 901,8 & & & 20,84 & 486,7 & 18,90 & 511.5 & & & 14,84 & 346,4 & 15,10 & 456.0 & & \\
\hline $\begin{array}{l}\text { Catel } \\
\text { Zcrokota } \\
\text { Hospe }\end{array}$ & $\begin{array}{l}31,86 \\
24,03 \\
35,70 \\
\end{array}$ & $\begin{array}{l}830,0 \\
865,9 \\
767,6 \\
\end{array}$ & & & & & $\begin{array}{r}6,10 \\
8,38 \\
28,20 \\
\end{array}$ & $\begin{array}{l}158,9 \\
281,1 \\
642,1 \\
\end{array}$ & & & & & $\begin{array}{r}27,70 \\
32,50 \\
9,08 \\
\end{array}$ & $\begin{array}{r}720,4 \\
1039,5 \\
206,0 \\
\end{array}$ & & . & & \\
\hline GISTEI & 31,31 & 819,5 & 33,93 & 987,2 & 32,08 & 1094,2 & 9,00 & $235.7^{\circ}$ & 10,12 & 294,0 & 9.57 & 326,4 & 25.89 & 677,1 & 21,80 & 635,2 & 28,32 & 965.7 \\
\hline $\begin{array}{l}\text { Fouteo } \\
\text { We Koron }\end{array}$ & $\begin{array}{l}41,15 \\
49,83 \\
\end{array}$ & $\begin{array}{l}1463,2 \\
3292,7 \\
\end{array}$ & & & & & $\begin{array}{r}15,60 \\
0,21 \\
\end{array}$ & $\begin{array}{r}554.7 \\
13.9 \\
\end{array}$ & & & & & $\begin{array}{l}11,26 \\
11,92 \\
\end{array}$ & $\begin{array}{l}400,4 \\
730,0 \\
\end{array}$ & & & · & - \\
\hline $200128 \%$ & 43.37 & 1747,8 & 50,13 & 3390,3 & 57,47 & 3049,7 & 11,67 & 470,5 & 10,54 & $644, ?$ & 0,42 & 631.5 & 11,40 & 459.3 & 5.16 & 300,3 & 7.32 & 490.2 \\
\hline $\begin{array}{l}\text { Iagur } \\
\text { Brtalon } \\
\text { St.Jar }\end{array}$ & $\begin{array}{l}20,48 \\
41,76 \\
26,37\end{array}$ & $\begin{array}{l}668.7 \\
865,0 \\
421,9\end{array}$ & & & & & $\begin{array}{r}2.56 \\
13.51 \\
0.71 \\
\end{array}$ & $\begin{array}{r}83,6 \\
280,0 \\
11,3 \\
\end{array}$ & & $\cdot$ & & & $\begin{array}{l}26,70 \\
21,91 \\
43,37 \\
\end{array}$ & $\begin{array}{l}871,7 \\
453,5 \\
693,5 \\
\end{array}$ & & & & \\
\hline IEFS? & 21.52 & 665,3 & 21,78 & 799,2 & 22.37 & 925,3 & 2,86 & 89,3 & 2,83 & 103.9 & 1,80 & 77.8 & 27,00 & 842,3 & 26,67 & 978,0 & 28,34 & 1972. \\
\hline 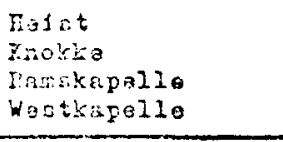 & $\begin{array}{l}19,21 \\
15,2 \\
21,09 \\
41,00 \\
\end{array}$ & $\begin{array}{r}991.5 \\
1313.8 \\
666.6 \\
1222,9 \\
\end{array}$ & & & & & $\begin{array}{r}4,68 \\
8,76 \\
16,63 \\
11,60 \\
\end{array}$ & $\begin{array}{l}241,6 \\
757,3 \\
525,5 \\
341,1 \\
\end{array}$ & & & & & $\begin{array}{l}20,50 \\
34,8 \\
21,16 \\
27,53 \\
\end{array}$ & $\begin{array}{r}1470,5 \\
3012,2 \\
677,8 \\
787.9 \\
\end{array}$ & & & & 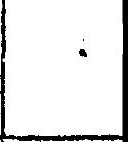 \\
\hline SNORYL-YEIST & 17.4 & $: 179,1$ & 17,4 & 1284,3 & & & 7,86 & 529,6 & 7,67 & 565,3 & & . & 32,6 & 2203,0 & 31,7 & 2335,5 & & \\
\hline 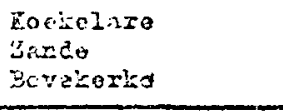 & $\begin{array}{l}50,14 \\
56,06 \\
30,02\end{array}$ & $\begin{array}{r}1205,6 \\
2192,4 \\
335,3\end{array}$ & & & & & $\begin{array}{l}0,48 \\
8,73 \\
1,76\end{array}$ & $\begin{array}{r}11,5 \\
341,4 \\
22,8\end{array}$ & & & & & $\begin{array}{r}23,97 \\
3,63 \\
16,09\end{array}$ & $\begin{array}{l}469,9 \\
141,8 \\
206,4\end{array}$ & & ? & & \\
\hline XOEZELARE & 45,00 & 1136,1 & 49,09 & 1268,9 & 52,11 & 1539.6 & 1,15 & 26,7 & 1,36 & 35,4 & 1,14 & 35.7 & 18,98 & 421,4 & 20,55 & 530.7 & 19,00 & 561. \\
\hline$\cdot$ & & & & $\cdot$ & & & $\cdot$ & & & & & & $\cdot$ & & & & & \\
\hline 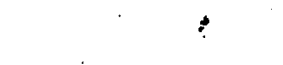 & & & & & & & & & & . & & & & $\therefore$. & & & & \\
\hline$\frac{4}{d}$ & & & & . & & & & & & & - & • & $\bullet$ & 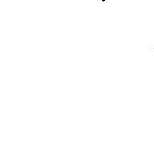 & & & & \\
\hline
\end{tabular}




\begin{tabular}{|c|c|c|c|c|c|c|c|c|c|c|c|c|c|c|c|c|c|c|}
\hline \multirow{4}{*}{ Geasento. } & \multicolumn{6}{|c|}{ ALCEWWE ADMTISTRATIE } & \multicolumn{6}{|c|}{ JUSTITIE-FOLITSE } & \multicolumn{6}{|c|}{ BRASTWFER } \\
\hline & \multirow{2}{*}{\multicolumn{2}{|c|}{$\frac{\operatorname{vos} x \text { fuspe }}{1970}$}} & \multicolumn{4}{|c|}{ na suelo } & \multirow{2}{*}{\multicolumn{2}{|c|}{$\frac{\nabla \delta b r \text { fusie }}{.1970}$}} & \multicolumn{4}{|c|}{ ne fugio } & \multirow{2}{*}{\multicolumn{2}{|c|}{$\frac{\text { rodr fuedo }}{1970}$}} & \multicolumn{4}{|c|}{ no rusio } \\
\hline & & & \multicolumn{2}{|c|}{1971} & \multicolumn{2}{|r|}{1972} & & & \multicolumn{2}{|c|}{1974} & \multicolumn{2}{|c|}{1972} & & & \multicolumn{2}{|c|}{1971} & \multicolumn{2}{|c|}{1972} \\
\hline & $\%$ & par inw. & $\%$ & por int. & $\$$ & per 1rs. & $\%$ & per 1nw. & $\underline{p}$ & $p \in r$ \&aw. & $\gamma^{\prime}$ & por lnw. & $\tilde{p}$ & per Inw. & $\%$ & per 1nw. & $\%$ & por i: \\
\hline $\begin{array}{l}\text { Langenark } \\
\text { Bisucineto }\end{array}$ & $\begin{array}{l}10,18 \\
23,00\end{array}$ & $\begin{array}{l}267,2 \\
508,4\end{array}$ & & & & & $\begin{array}{l}4,75 \\
8,38\end{array}$ & $\begin{array}{l}124,7 \\
214,4\end{array}$ & & & & & $\begin{array}{l}1,21 \\
1,40\end{array}$ & $\begin{array}{l}31,8 \\
35,9\end{array}$ & & & & - \\
\hline Laveteviry & 11,76 & 307,7 & 13,49 & 389,8 & 12,57 & 382,9 & 5,20 & $136, i$ & 6,24 & 180.4 & 6,39 & 994,7 & 1,23 & 32,3 & 0,71 & 20,5 & 1,27 & 30 \\
\hline 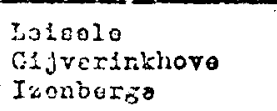 & $\begin{array}{l}10,75 \\
25,97 \\
35,75\end{array}$ & $\begin{array}{l}519.5 \\
607.5 \\
700.6\end{array}$ & & & & & $\begin{array}{r}4,06 \\
11,49 \\
10,00\end{array}$ & $\begin{array}{l}196,5 \\
311,0 \\
277.5\end{array}$ & & & . & & $\begin{array}{l}0,92 \\
1,22 \\
1,38\end{array}$ & $\begin{array}{l}44,0 \\
36,4 \\
38,0\end{array}$ & & & & \\
\hline IETSELE & $15,8 x$ & 600,8 & 18,14 & 767,9 & 18,36 & 896,0 & 6,51 & 250,6 & 7,32 & 309.9 & 6.69 & 326,9 & 1,06 & 41,1 & - & - & 0,02 & 40 \\
\hline $\begin{array}{l}\text { Foillaishoro } \\
\text { I.o. }\end{array}$ & $\begin{array}{l}15,51 \\
10,00\end{array}$ & $\begin{array}{l}560,8 \\
443, i\end{array}$ & & & & & $\begin{array}{l}5,04 \\
4,55\end{array}$ & $\begin{array}{l}192,1 \\
200,4\end{array}$ & & & & & $\begin{array}{l}1,12 \\
2,72\end{array}$ & $\begin{array}{r}40,6 \\
119,7\end{array}$ & & & & \\
\hline Lo & 12,20 & 494.7 & 12,15 & 544,3 & 13,49 & 652,0 & 4.74 & $: 92,4$ & 5.04 & 226,2 & 4,35 & 210,3 & 2,09 & 85.0 & 9,94 & 07.1 & 1,70 & 32 \\
\hline $\begin{array}{l}\text { Yoszkerko } \\
\text { lonocheuro } \\
\text { Konte }\end{array}$ & $\begin{array}{l}16,10 \\
13,82 \\
23,99\end{array}$ & $\begin{array}{r}374,6 \\
721.4 \\
1105.5\end{array}$ & & & & & $\begin{array}{l}4,17 \\
8,76 \\
3,12\end{array}$ & $\begin{array}{r}96,5 \\
457,2 \\
374,6\end{array}$ & & & & & $\begin{array}{l}1,52 \\
1,06 \\
0,94\end{array}$ & $\begin{array}{l}35,2 \\
55,6 \\
43,3\end{array}$ & & & & \\
\hline xondures & 16,39 & 462,3 & 16,16 & 554,3 & 16,68 & 620,9 & 5,63 & 150,9 & 5,63 & 193,1 & 5,70 & 212,1 & 1,35 & 30,3 & - & - & - & \\
\hline 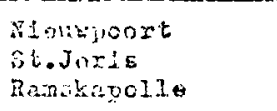 & $\begin{array}{r}6,34 \\
17,87 \\
24,54\end{array}$ & $\begin{array}{l}699.6 \\
6,5,3 \\
660,4\end{array}$ & & & & & $\begin{array}{r}0,48 \\
6,47 \\
10,44\end{array}$ & $\begin{array}{l}715,4 \\
230 ; 3 \\
281,8\end{array}$ & & & & & $\begin{array}{l}0,80 \\
1,13 \\
1,63\end{array}$ & $\begin{array}{c}80,3 \\
40,3 \\
-\end{array}$ & & & & \\
\hline 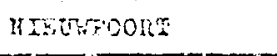 & 6,91 & 693.6 & 6,91 & 304,1 & 7,32 & $96 a ́, 0$ & 6,56 & 659,2 & 6,30 & 733,4 & 6,42 & $8,6,9$ & 0,32 & 82,6 & 0,72 & 84,1 & 0,02 & ico \\
\hline 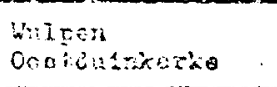 & $\begin{array}{l}20,63 \\
i 3,69\end{array}$ & $\begin{array}{l}497,7 \\
651,2\end{array}$ & & & & & $\begin{array}{r}9.71 \\
13.20\end{array}$ & $\begin{array}{l}229,6 \\
820 ; e^{2}\end{array}$ & & & & & $\begin{array}{l}1,75 \\
1,42\end{array}$ & $\begin{array}{l}41,4 \\
8 E, 5\end{array}$ & . & & & \\
\hline ooviviniveses & 34,14 & 795.9 & 14,15 & 887,5 & 14,84 & 1054,9 & 12,93 & 730,8 & 12,39 & 808,4 & 12,97 & 204,5 & 1,44 & 61,3 & 1,76 & 110,8 & 1,19 & 98 \\
\hline $\begin{array}{l}\text { Sogtondo } \\
\text { Stcrto } \\
\text { Sinstrouris }\end{array}$ & $\begin{array}{r}7,66 \\
15,32 \\
15,63\end{array}$ & $\begin{array}{l}049,0 \\
296 ; 3 \\
352,0\end{array}$ & & & & & $\begin{array}{l}9,52 \\
3,68 \\
2,90\end{array}$ & $\begin{array}{r}94,3 \\
68,9 \\
67,8\end{array}$ & & & & & $\begin{array}{l}4,61 \\
2,09 \\
1,24\end{array}$ & $\begin{array}{r}511.5 \\
39.1 \\
37.5\end{array}$ & & $\cdot$ & & \\
\hline 00دmisus & 7,94 & 743.7 & 7,99 & 929.5 & 7.70 & $943.9:$ & 8,30 & $777 \% 4$ & 8,40 & 871,4 & 9.33 & 1143.2 & 4.49 & 420,9 & 4,37 & 453.9 & 4.87 & 596 \\
\hline
\end{tabular}




\begin{tabular}{|c|c|c|c|c|c|c|c|c|c|c|c|c|c|c|c|c|c|c|}
\hline \multirow{4}{*}{ Gancento } & \multicolumn{6}{|c|}{ VEIREER - WEGEH - WATEILOPEN } & \multicolumn{6}{|c|}{ KLEOTER- EN LAGER ONDERWIJS } & \multicolumn{6}{|c|}{ VERZORGENDE TAKEN } \\
\hline & \multirow{2}{*}{\multicolumn{2}{|c|}{$\frac{\text { vodr facto }}{1970}$}} & \multicolumn{4}{|c|}{ na fualo } & \multirow{2}{*}{\multicolumn{2}{|c|}{$\frac{\text { vobre fuein }}{1970}$}} & \multicolumn{4}{|c|}{ na fuato } & \multirow{2}{*}{\multicolumn{2}{|c|}{$\frac{. \text { vobr fueio }}{1970}$}} & \multicolumn{4}{|c|}{ na furio } \\
\hline & & & \multicolumn{2}{|c|}{1971} & \multicolumn{2}{|c|}{1972} & & & \multicolumn{2}{|c|}{. 1971.} & \multicolumn{2}{|c|}{ i972 } & & & \multicolumn{2}{|c|}{1971} & \multicolumn{2}{|r|}{1972} \\
\hline & $\%$ & per 1nw. & $\not$ & per snw. & \%6 & par inw. & so & por ink. & $\%$ & per law. & $\%$ & per inw. & $\%$ & per Inw. & $\%$ & per inw. & $\%$ & por 1nw. \\
\hline 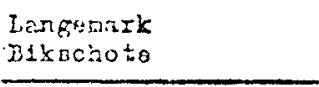 & $\begin{array}{l}41,75 \\
27,40 \\
\end{array}$ & $\begin{array}{r}1095,8 \\
701,: \\
\end{array}$ & & & & & $\begin{array}{r}0,84 \\
26,96\end{array}$ & $\begin{array}{r}22,2 \\
689,0 \\
\end{array}$ & & & & & $\begin{array}{l}27,00 \\
12,51\end{array}$ & $\begin{array}{l}700,2 \\
320,0\end{array}$ & & & & \\
\hline LASCER:LZZ & 39,98 & 1046,0 & 40,40 & 1166,9 & 39.77 & 1211,6 & 4.06 & 106,4 & 1.42 & 41,1 & 1,76 & 54,4 & 25,21 & 659,2 & 23.72 & 684,0 & 25,27 & .759 .6 \\
\hline $\begin{array}{l}\text { Lefuela } \\
\text { ifjuerinichoro } \\
\text { Izonbargo }\end{array}$ & $\begin{array}{l}69,04 \\
27,14 \\
20,29\end{array}$ & $\begin{array}{r}3287,0 \\
805,4 \\
770,6\end{array}$ & & & & & $\begin{array}{r}9,15 \\
19,73 \\
12,04\end{array}$ & $\begin{array}{l}456,7 \\
585,5 \\
331,5\end{array}$ & & & & & $\begin{array}{r}5,21 \\
16,53 \\
21,48\end{array}$ & $\begin{array}{l}247,1 \\
190,5 \\
591,1\end{array}$ & & & & \\
\hline LEISELE & 53,23 & 2047,2 & 53,63 & 2270,7 & 52,65 & 2569,1 & 11,71 & 450.5 & $i 1,03$ & 467,0 & 10,28 & 501,8 & 10.29 & 395,0 & 0,22 & 348,1 & 9,84 & 480,0 \\
\hline $\begin{array}{l}\text { Follinkhoro } \\
\text { Lo }\end{array}$ & $\begin{array}{l}46,88 \\
53,84\end{array}$ & $\begin{array}{r}1694,7 \\
2366,6 \\
\end{array}$ & & & & & $\begin{array}{r}17,04 \\
9,69 \\
\end{array}$ & $\begin{array}{l}616,0 \\
426,0 \\
\end{array}$ & & & & & $\begin{array}{l}12.65 \\
15.97 \\
\end{array}$ & $\begin{array}{l}457,1 \\
789,2 \\
\end{array}$ & & & & \\
\hline LO & 51,12 & 2071,3 & 50,58 & 2268,0 & 48,27 & 2331,6 & 12,57 & 509,4 & 11,98 & 537,3 & 11,55 & 558,1 & 14,67 & 594,3 & 16,61 & 744,6 & 18,83 & 909,3 \\
\hline $\begin{array}{l}\text { Moezkouke } \\
\text { Leochesuro } \\
\text { Hoske }\end{array}$ & $\begin{array}{l}33,46 \\
61,23 \\
15,52\end{array}$ & $\begin{array}{r}774,3 \\
3195,0 \\
716,1\end{array}$ & & & .. & & $\begin{array}{r}14,61 \\
6,74 \\
32,19\end{array}$ & $\begin{array}{r}338,3 \\
351,9 \\
1484,8\end{array}$ & & & & . & $\begin{array}{r}28,33 \\
5,29 \\
16,98\end{array}$ & $\begin{array}{l}655,3 \\
276,0 \\
783,1\end{array}$ & & & & \\
\hline lofrinta & 38,25 & 1078,8 & 36,13 & 1239.5 & 39,79 & 1481,0 & 14,47 & 400,3 & 15,93 & 546.7 & 14.71 & 547,7 & 21,80 & 614,7 & 24,03 & 824,0 & 21,25 & 790,5 \\
\hline 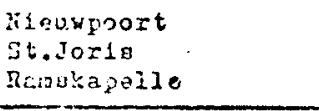 & $\begin{array}{r}9,61 \\
12,06 \\
26,97\end{array}$ & $\begin{array}{r}1065,5 \\
428,7 \\
725,2\end{array}$ & & & & & $\begin{array}{r}0,48 \\
46,96 \\
14,72\end{array}$ & $\begin{array}{r}53,3 \\
1669,3 \\
396,1\end{array}$ & & & & & $\begin{array}{r}8,61 \\
11,22 \\
35,36\end{array}$ & $\begin{array}{l}949,4 \\
368,6 \\
413,1\end{array}$ & & & & \\
\hline RISUWTOOET & 10,01 & 1005,3 & 10,34 & 1203,4 & 8,84 & 1166,0 & 1,53 & 153,5 & $1 ; 56$ & 181,7 & 1,44 & 190,3 & 8,79 & 882,3 & 10,83 & 1259,8 & 10,3 & 1364.5 \\
\hline 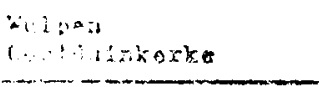 & $\begin{array}{l}34,19 \\
29,55\end{array}$ & $\begin{array}{r}803,3 \\
1037,6 \\
\end{array}$ & & & & & $\begin{array}{r}22,54 \\
6,04\end{array}$ & $\begin{array}{r}532,8 \\
375,9\end{array}$ & & & & & $\begin{array}{r}9,03 \\
26,89\end{array}$ & $\begin{array}{r}213,4 \\
1 \in 71,1\end{array}$ & & & & . \\
\hline osouncutiuse & 29.86 & 1680,9 & 26,63 & 1795,7 & 28,94 & 2017,9 & 7,10 & 399,0 & 7,48 & 469,3 & 7,41 & 516,8 & 25,75 & 1449,3 & 26,52 & 1663,3 & 27,49 & 1917,0 \\
\hline $\begin{array}{l}\text { Costuade } \\
\text { Stena } \\
\text { Zinäroorja }\end{array}$ & $\begin{array}{r}8,56 \\
42,90 \\
28,75 \\
\end{array}$ & $\begin{array}{l}959,6 \\
801,8 \\
870,0 \\
\end{array}$ & & & & & $\begin{array}{r}10,8 \\
0,26 \\
21,96 \\
\end{array}$ & $\begin{array}{r}1205,0 \\
5,0 \\
664,7 \\
\end{array}$ & . & & & - & $\begin{array}{l}26,8 \\
33,11 \\
39,84\end{array}$ & $\begin{array}{r}2977.9 \\
618,4 \\
963.6 \\
\end{array}$ & & & & \\
\hline COSTEDL & 9.95 & 932,0 & 9.84 & 1021,6 & 9,70 & $1198,0$. & 10,6 & 998,5 & 10,4 & 1087.3 & 9.72 & 1190,4 & 27.1 & 2539.1 & 28,4 & 2946,5 & 27.5 & 3376,6 \\
\hline
\end{tabular}




\begin{tabular}{|c|c|c|c|c|c|c|c|c|c|c|c|c|c|c|c|c|c|c|}
\hline \multirow{4}{*}{ Gensonte } & \multicolumn{6}{|c|}{ AT.GEMETE ADMINISTRATTE } & \multicolumn{6}{|c|}{ JUSTITIE-POLITIE } & \multicolumn{6}{|c|}{ BRANDWEER } \\
\hline & \multirow{2}{*}{\multicolumn{2}{|c|}{$\begin{array}{c}\text { vose fug10 } \\
1970\end{array}$}} & \multicolumn{4}{|c|}{$n \& f_{n \rightarrow B 10}$} & \multirow{2}{*}{\multicolumn{2}{|c|}{$\frac{\text { osse fuofio }}{1970}$}} & \multicolumn{4}{|c|}{ na fugto } & \multirow{2}{*}{\multicolumn{2}{|c|}{$\frac{\text { vobs fua10 }}{1970}$}} & \multicolumn{4}{|c|}{ na fualo } \\
\hline & & & \multicolumn{2}{|c|}{$197:$} & \multicolumn{2}{|c|}{1972} & & & \multicolumn{2}{|c|}{1971} & \multicolumn{2}{|c|}{1972} & & & \multicolumn{2}{|c|}{1971} & \multicolumn{2}{|c|}{1972} \\
\hline & $\%$ & per lnw. & $\mathscr{\%}$ & por lay. & $\not 0$ & por irw. & $\%$ & por inin. & $\not$ & per Inw. & $\%$ & por inw. & $\%$ & per Inw. & $\%$ & per law. & $\%$ & per lnw \\
\hline 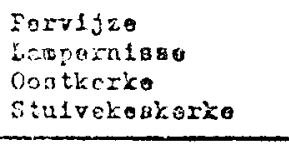 & $\begin{array}{l}19,28 \\
19,04 \\
16,73 \\
21,64 \\
\end{array}$ & $\begin{array}{r}595.5 \\
984.6 \\
662.0 \\
1175,7 \\
\end{array}$ & & & & & $\begin{array}{r}6,70 \\
9,94 \\
8,84 \\
10,14 \\
\end{array}$ & $\begin{array}{l}206.9 \\
514.9 \\
355,4 \\
551.1\end{array}$ & & : & & & $\begin{array}{l}1,23 \\
1,58 \\
0,50 \\
1,05\end{array}$ & $\begin{array}{l}38,1 \\
82,1 \\
35,7 \\
57,3\end{array}$ & & & & \\
\hline PENVISZT & 19,10 & 713,4 & 15.51 & 745,4 & 12,57 & $715, i$ & 6.09 & 302,1 & 7,50 & 360,6 & 6,77 & 384,9 & 2,20 & 44,9 & 0,96 & 46,4 & 1,34 & 76,6 \\
\hline $\begin{array}{l}\text { Prover } \\
\text { Yrosobolo }\end{array}$ & $\begin{array}{l}13,00 \\
22,41\end{array}$ & $\begin{array}{l}351,7 \\
744,1\end{array}$ & & & & & $\begin{array}{l}3,90 \\
4,27\end{array}$ & $\begin{array}{l}100,5 \\
141: 8\end{array}$ & & & & & $\begin{array}{l}4,37 \\
1,10\end{array}$ & $\begin{array}{r}121,7 \\
36,5\end{array}$ & & & & \\
\hline Frover & 16.80 & 500,2 & 13,02 & 433.5 & & & 4,05 & 120,6 & 4,45 & 148,3 & & . & 3,05 & 90,8 & 1,98 & 66,2 & & \\
\hline $\begin{array}{l}\text { Bentaga } \\
\text { Biooedschoto }\end{array}$ & $\begin{array}{l}15,64 \\
16,08\end{array}$ & $\begin{array}{l}411,2 \\
703,4\end{array}$ & & & & & $\begin{array}{l}3,86 \\
3,73\end{array}$ & $\begin{array}{l}117.1 \\
156.7\end{array}$ & & & & & $\begin{array}{l}1,58 \\
1,09\end{array}$ & $\begin{array}{l}47,5 \\
46,1\end{array}$ & & & & \\
\hline FWIKGE & 14,69 & 487,4 & 12,49 & 515,7 & 14,05 & 567,6 & 3,83 & 127,3 & 3,75 & 155,2 & 4,05 & 163,8 & 1,42 & 47,2 & 2,53 & 104,6 & 1,51 & 61,1 \\
\hline 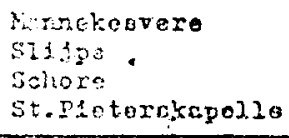 & $\begin{array}{l}31,90 \\
20,75 \\
39,07 \\
26,18\end{array}$ & $\begin{array}{r}1211,3 \\
500,5 \\
945,0 \\
1017,5\end{array}$ & & . & & & $\begin{array}{r}9,07 \\
8,64 \\
16,82 \\
8,78\end{array}$ & $\begin{array}{l}344,5 \\
24,19 \\
400,2 \\
341,3\end{array}$ & & & & ' & $\begin{array}{l}1,13 \\
1,36 \\
1,85 \\
1,11\end{array}$ & $\begin{array}{l}43,1 \\
33,6 \\
45,0 \\
43,3\end{array}$ & & & & \\
\hline StandLIR & 25,95 & 750,4 & 21,11 & 677.1 & & & 9,68 & 291.0 & 10,54 & 338,3 & & & 1,53 & 40,2 & 1,23 & 39,5 & & \\
\hline $\begin{array}{l}\text { Stavolo } \\
\text { Pererez }\end{array}$ & $\begin{array}{r}15,73 \\
24,50 \\
\end{array}$ & $\begin{array}{l}550,1 \\
505.0 \\
\end{array}$ & & . & & & $\begin{array}{r}6,19 \\
13,26 \\
\end{array}$ & $\begin{array}{l}216,6 \\
273,4 \\
\end{array}$ & & & & & $\begin{array}{l}1,10 \\
1,90 \\
\end{array}$ & $\begin{array}{l}41,4 \\
39,1 \\
\end{array}$ & & & & \\
\hline Staves & 19.35 & 525,6 & 20,58 & 670.7 & 16,63 & 600,3 & 9,11 & 247,5 & 9,91 & 323,0 & 9,90 & 357,5 & $1,4 ?$ & 10,1 & 1,27 & 41,6 & $i, 92$ & 69.6 \\
\hline 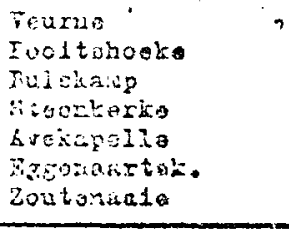 & $\begin{array}{l}13,16 \\
42,35 \\
10,26 \\
19,62 \\
26,43 \\
20,83 \\
50,19 \\
\end{array}$ & $\begin{array}{r}453,5 \\
1822.8 \\
463.9 \\
725.7 \\
660.9 \\
647,4 \\
4316.3 \\
\end{array}$ & $\therefore$ & & & & $\begin{array}{r}10,45 \\
2,30 \\
11,03 \\
8,70 \\
1,744 \\
2,99 \\
25,44 \\
25\end{array}$ & $\begin{array}{r}360,9 \\
97,9 \\
289,8 \\
327,9 \\
265,6 \\
279,8 \\
2187,7 \\
\end{array}$ & & & & & $\begin{array}{l}5,29 \\
.0,79 \\
1,44 \\
1,26 \\
1,32 \\
i, 22 \\
0,87\end{array}$ & $\begin{array}{r}182,4 \\
33,5 \\
35,6 \\
46,6 \\
33,2 \\
38,0 \\
75,5\end{array}$ & & - & & - \\
\hline VETare & 15,32 & 522,7 & 14,18 & 575.9 & 12,84 & 623.5 & 10,33 & 352,2 & 8,44 & 342,8 & 7.85 & 301,4 & 4,50 & 153,7 & 6,21 & 252,3 & 6,43 & 312,3 \\
\hline
\end{tabular}




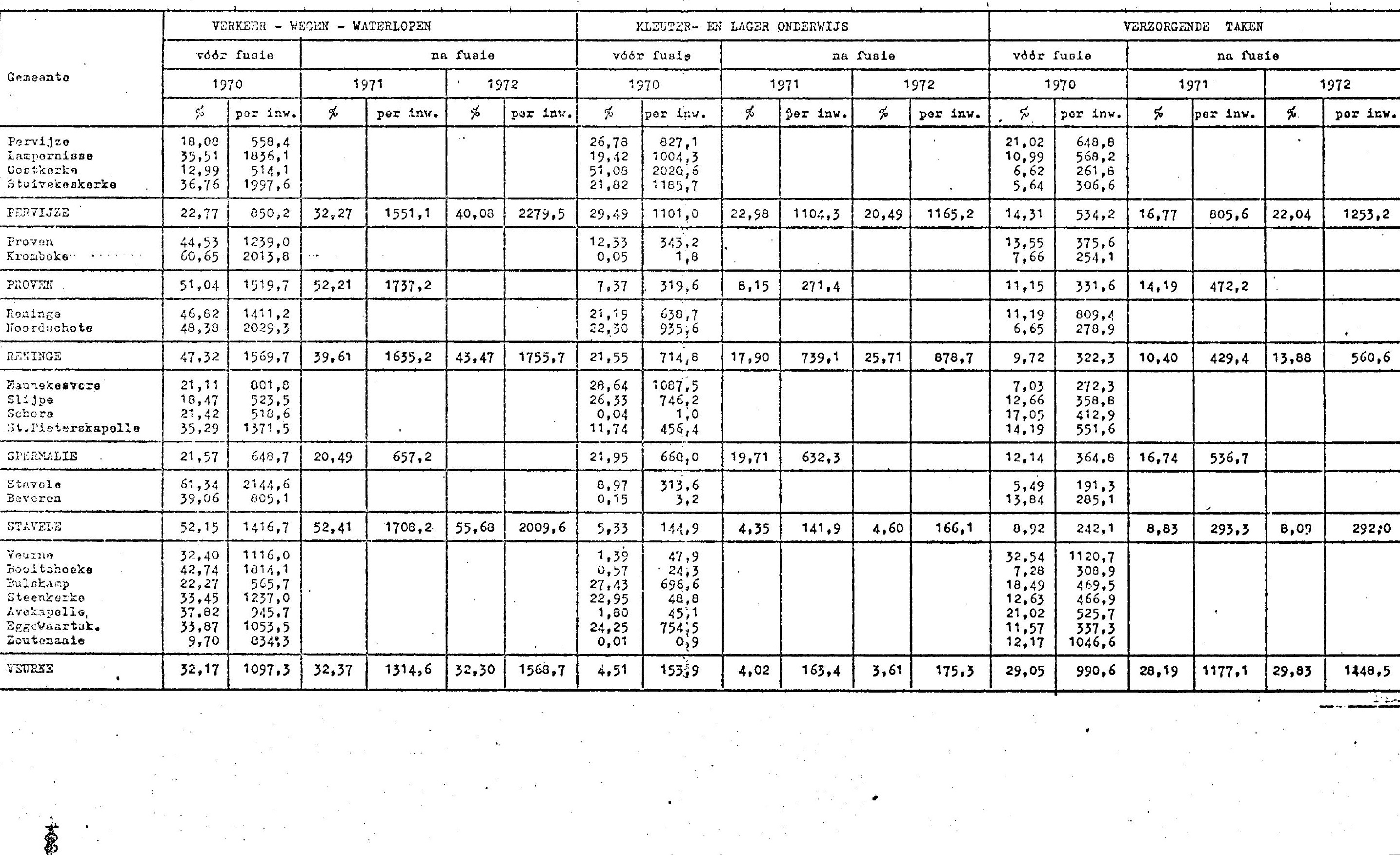




\begin{tabular}{|c|c|c|c|c|c|c|c|c|c|c|c|c|c|c|c|c|c|c|}
\hline \multirow{4}{*}{ Gemeonta } & \multicolumn{6}{|c|}{ SLGEMENE ADKTHISTRATIF } & \multicolumn{6}{|c|}{ JUSTITIE-POLINIE } & \multicolumn{6}{|c|}{ BRANDWERR } \\
\hline & \multirow{2}{*}{\multicolumn{2}{|c|}{$\frac{\text { vods susio }}{1970}$}} & \multicolumn{4}{|c|}{$2 a$ fuato } & \multirow{2}{*}{\multicolumn{2}{|c|}{$\frac{\nabla 88 x \operatorname{fnzi\theta }}{1970}$}} & \multicolumn{4}{|c|}{ na fusto } & \multirow{2}{*}{\multicolumn{2}{|c|}{$\frac{\text { vodr fusio }}{1970}$}} & \multicolumn{4}{|c|}{ na rusio } \\
\hline & & & \multicolumn{2}{|c|}{1971} & \multicolumn{2}{|c|}{1972} & & & \multicolumn{2}{|r|}{1971} & \multicolumn{2}{|c|}{1972} & & & \multicolumn{2}{|c|}{$197 i$} & \multicolumn{2}{|c|}{1972} \\
\hline & $\%$ & por 1nw. & $\not$ & par 1nw. & $\%$ & pex tnw. & $q^{\prime}$ & por inw. & $\%$ & per jnw. & $\mathscr{g}$ & per inw. & $\%$ & per 1nw. & $q^{\prime}$ & por lnw. & $\not$ & par lnw. \\
\hline $\begin{array}{l}\text { Hostende } \\
\text { iugbarizijdo }\end{array}$ & $\begin{array}{l}15,33 \\
18,82 \\
\end{array}$ & $\begin{array}{l}654.7 \\
469.3 \\
\end{array}$ & & & & & $\begin{array}{r}12,30 \\
9.90 \\
\end{array}$ & $\begin{array}{l}600,0 \\
2.18,9 \\
\end{array}$ & & & . & & $\begin{array}{l}1,55 \\
1,42 \\
\end{array}$ & $\begin{array}{l}76,3 \\
35,1\end{array}$ & & & & \\
\hline Hestatise & $: 4,6 i$ & 585,0 & 15,41 & 668,2 & 16,83 & 897,6 & 11,82 & 473,1 & 13,04 & 565,4 & 14,12 & 753,1 & $i, 52$ & 60.9 & 1,40 & 61,0 & 1,13 & 60,3 \\
\hline $\begin{array}{l}\text { Werken } \\
\text { Warren }\end{array}$ & $\begin{array}{l}12,78 \\
11,57 \\
\end{array}$ & $\begin{array}{l}375,3 \\
3,52,6 \\
\end{array}$ & & & . & & $\begin{array}{l}4,68 \\
3.71 \\
\end{array}$ & $\begin{array}{l}137,4 \\
113,1\end{array}$ & & . & & & $\begin{array}{l}1,17 \\
1,09\end{array}$ & $\begin{array}{l}34,6 \\
33,4\end{array}$ & & & & \\
\hline 2AREST-XERTES & 14,35 & 360,3 & 12,60 & 472,0 & 12,97 & 518,7 & 4.83 & 121,3 & 4,24 & 159,0 & 4,25 & 170,3 & 1,12 & 33.8 & 0,98 & 36,9 & 0,92 & 37,1 \\
\hline $\begin{array}{l}\text { zilloboka } \\
\text { Toozaczelo } \\
\text { Boiluboiso }\end{array}$ & $\begin{array}{l}12,72 \\
14,80 \\
15,05\end{array}$ & $\begin{array}{l}300,0 \\
370,3 \\
301,9\end{array}$ & & & & & $\begin{array}{l}4,51 \\
6,40 \\
9,90\end{array}$ & $\begin{array}{l}105,5 \\
162,4 \\
25: 3\end{array}$ & & & & & $\begin{array}{l}1,45 \\
1,46 \\
1,30\end{array}$ & $\begin{array}{l}35,3 \\
36,7 \\
33,2\end{array}$ & . & & & \\
\hline ZYXXISTER & 13,02 & 341,7 & 14,50 & 405,6 & & & 6,21 & $15 x, 6$ & 6,13 & 173,0 & & & 1,43 & 35,3 & 1,38 & 38,6 & & \\
\hline
\end{tabular}




\begin{tabular}{|c|c|c|c|c|c|c|c|c|c|c|c|c|c|c|c|c|c|c|}
\hline \multirow{4}{*}{ Gemeente } & \multicolumn{6}{|c|}{ VERKEER - WEGET - VATERLOPEN } & \multicolumn{6}{|c|}{ KLEOTER- EN LAGAR ORDERWIJS } & \multicolumn{6}{|c|}{ VERZORGENDE TAKEN } \\
\hline & \multirow{2}{*}{\multicolumn{2}{|c|}{$\frac{v 33 x \text { fusie }}{1970}$}} & \multicolumn{4}{|c|}{ na $f$ woio } & \multirow{2}{*}{\multicolumn{2}{|c|}{$\frac{\text { vodor fuste }}{.1970}$}} & \multicolumn{4}{|c|}{ na fuste } & \multirow{2}{*}{\multicolumn{2}{|c|}{$\frac{\text { vosx fusio }}{1970}$}} & \multicolumn{4}{|c|}{ na fusio } \\
\hline & & & \multicolumn{2}{|c|}{1971} & \multicolumn{2}{|c|}{1972} & & & \multicolumn{2}{|c|}{1971} & \multicolumn{2}{|c|}{19.72} & & & \multicolumn{2}{|c|}{1971} & \multicolumn{2}{|c|}{1972} \\
\hline & $\tilde{\%}$ & per inw, & $\mathscr{8}$ & por lnw. & ro & por inw. & $\%$ & Dor Inw. & $\%$ & per sny. & 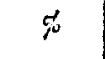 & por inw. & sis & por inw. & $\%$ & por lnw. & $q$ & per inw. \\
\hline $\begin{array}{l}\text { Wostende } \\
\text { Lorbardz1fdo }\end{array}$ & $\begin{array}{l}13.67 \\
14,17 \\
\end{array}$ & $\begin{array}{l}679.7 \\
353.4\end{array}$ & & & & & $\begin{array}{r}8.39 \\
17.44 \\
\end{array}$ & $\begin{array}{l}411,8 \\
434,7 \\
\end{array}$ & & & & & $\begin{array}{l}46,53 \\
36,39 \\
\end{array}$ & $\begin{array}{r}2285,5 \\
907.0 \\
\end{array}$ & & & & \\
\hline nistang & 13,79 & 552,1 & 15,66 & 679,0 & 15.63 & 833.8 & 10,50 & 429,4 & 11,04 & 478,6 & 10,94 & 583,4 & 44,16 & 1767.5 & 39,25 & 1701,0 & 36,29 & 1934,9 \\
\hline $\begin{array}{l}\text { Dorken } \\
\text { Garzen }\end{array}$ & $\begin{array}{l}40,83 \\
53,55\end{array}$ & $\begin{array}{l}1133,8 \\
1639,9\end{array}$ & & & & & $\begin{array}{l}21,89 \\
16,20 \\
\end{array}$ & $\begin{array}{l}649,5 \\
453,8\end{array}$ & & & & & $\begin{array}{r}9,94 \\
13,42 \\
\end{array}$ & $\begin{array}{l}291,8 \\
408,7 \\
\end{array}$ & & " & & \\
\hline ZARTFU-WEREEX & 52,00 & 1565,07 & 55,41 & 2074,7 & 52,41 & $2096 ; 2$ & 18,05 & 543.4 & 14,52 & 543,3 & 14,77 & 590,8 & 12,27 & 369,2 & 11,76 & 439,9 & 13,82 & 552,4 \\
\hline $\begin{array}{l}\text { Z1jzobake } \\
\text { Poomezezelo } \\
\text { Eolloboto }\end{array}$ & $\begin{array}{l}40,39 \\
34,41 \\
59,25\end{array}$ & $\begin{array}{l}980,5 \\
86:, 6 \\
996,1 \\
\end{array}$ & & & · & & $\begin{array}{l}19,35 \\
23,01 \\
27,30 \\
\end{array}$ & $\begin{array}{l}469,8 \\
5 \% 5,3 \\
64,2 \\
67,7 \\
\end{array}$ & & . & & & $\begin{array}{r}20,11 \\
17,31 \\
5,23 \\
\end{array}$ & $\begin{array}{l}488,0 \\
433,1 \\
132,5 \\
\end{array}$ & & & & \\
\hline zZuLExtos & 30,54 & 947,9 & 35.51 & 993,0 & & & 22,05 & $5 \$ 5.5$ & 23,69 & $.662,6$ & & & 11,79 & 291,3 & 17.16 & 479,9 & & \\
\hline
\end{tabular}


Bijlage 2-C Iinanciële gegevens over de fusiegemeante BFUGGE

GLWONE REKENINGEN DIENSTJAAR 1970 - INKONSTEN EN UITGAVEN IN ABSOLUTE GETALIEN

In duizende $F$

\begin{tabular}{|c|c|c|c|c|c|c|c|c|}
\hline & \multicolumn{4}{|c|}{ Totaal eigen dienstjaar } & \multicolumn{4}{|c|}{ Algemeen totaal } \\
\hline & $\begin{array}{l}\text { Vastgeatelde } \\
\text { rechuen }\end{array}$ & $\begin{array}{l}\text { Vastgesteide } \\
\text { uitgaven }\end{array}$ & $\begin{array}{l}\text { Positief of } \\
\text { negatiel } \\
\text { salco }\end{array}$ & & $\begin{array}{l}\text { Vastsestelde } \\
\text { rechten }\end{array}$ & $\begin{array}{l}\text { Vastgestelde } \\
\text { uitgaven }\end{array}$ & $\begin{array}{l}\text { Positief of } \\
\text { negatief } \\
\text { saldo }\end{array}$ & \\
\hline ASSEBROEK & 39.087 & 31.945 & +7.141 & $22,35 \%$ & 60.275 & 36.183 & +24.092 & $66,58 q$ \\
\hline DUDZETE & 6.092 & 5.720 & $-\quad 628$ & $9.35 \%$ & 8.146 & 6.998 & +1.147 & $16,40 \%$ \\
\hline KOOLERREE & 3.592 & 3.335 & $+\quad 257$ & $7,70 \%$ & 3.935 & 3.471 & +463 & $13,34 \%$ \\
\hline LIESEWEGE & 5.581 & 4.929 & +652 & $13,23 \%$ & 7.023 & 5.700 & +1.322 & $23,20 \%$ \\
\hline SINT-ANDRIES & 50.034 & 48.323 & +1.711 & $3.54 \%$ & 70.988 & 56.754 & +14.233 & $25,08 \%$ \\
\hline SIM-IRUIS & 35.069 & 30.752 & +4.317 & $14,04 \%$ & 42.737 & 34.808 & +7.929 & 22,78 , \\
\hline SINT-IVICHIELS & 54.590 & 53.375 & +1.214 & $2,28 \%$ & 61.701 & 54.237 & +7.463 & 13.76 \\
\hline BRUGGE & 326.069 & 311.921 & +14.147 & $4,54 \%$ & 356.084 & 316.575 & +39.508 & $12,48 g$ \\
\hline TOTAAL & 520.118 & 491.304 & +28.813 & $5,86 \%$ & 610.893 & 514.731 & +96.162 & 18,68 \\
\hline BRUGGE 1971 & 541.647 & 550.314 & -8.667 & $-1.57 \%$ & 647.937 & 565.142 & +82.795 & $14,65 \%$ \\
\hline BPUGGE 1972 & 673.743 & 682.743 & -9.000 & $-1,32 \%$ & 776.865 & 704.569 & +72.296 & $10,26 \%$ \\
\hline $\begin{array}{l}\text { BRUGCE } 1973 \\
\text { (begroting) }\end{array}$ & 840.969 & 928.353 & -87.363 & $-9,41 \%$ & 938.953 & 938.953 & - & 0,009 \\
\hline
\end{tabular}




\begin{tabular}{|c|c|c|c|c|c|c|c|}
\hline & \multicolumn{3}{|c|}{ Totaal eteen dienstjaan } & \multicolumn{4}{|c|}{ Algemeen totaal } \\
\hline & $\begin{array}{l}\text { Vastgestelde } \\
\text { rechten }\end{array}$ & $\begin{array}{l}\text { Vastgestelde } \\
\text { uitgaven }\end{array}$ & $\begin{array}{l}\text { Positief of } \\
\text { regatief saldo }\end{array}$ & $\begin{array}{l}\text { Vastgestelde } \\
\text { rechten }\end{array}$ & $\begin{array}{l}\text { Vastgestelde } \\
\text { uitgaven }\end{array}$ & $\begin{array}{l}\text { Posi } \\
\text { nega }\end{array}$ & $\begin{array}{l}\text { tief of } \\
\text { tief saldo }\end{array}$ \\
\hline ASSEBROEK & 2.527 & 2.065 & +461 & 3.897 & 2.339 & & 1.557 \\
\hline DUDZETE & 2.939 & 3.242 & -302 & 3.929 & 3.376 & + & 553 \\
\hline KOOLKERKE & 2.043 & 1.897 & +146 & 2.238 & 1.974 & + & 263 \\
\hline LISSTWLCE & 2.512 & 2.218 & +293 & 3.161 & 2.565 & + & 595 \\
\hline SINI-ANDRIES & 3.051 & 2.947 & +.204 & 4.329 & 3.461 & + & 868 \\
\hline SINT-KRUIS & 2.613 & 2.291 & +321 & 3.184 & 2.593 & + & 590 \\
\hline SINP-MICLIELS & 4.165 & 4.072 & +92 & 4.707 & 4.138 & + & 569 \\
\hline BRUGGE & 6.335 & 6.061 & +274 & 6.919 & 6.151 & + & 767 \\
\hline$T O T A A L$ & 4.487 & 4.239 & +248 & 5.270 & 4.441 & + & 829 \\
\hline BNUGG 1971 & 4.620 & 4.694 & -73 & 5.527 & 4.821 & + & 706 \\
\hline BRUGGE 1972 & 5.708 & 5.784 & -76 & 6.582 & 5.969 & + & 612 \\
\hline $\begin{array}{l}\text { BRUGGE } 1973 \\
\text { (begroting) }\end{array}$ & 7.088 & 7.818 & -735 & 7.709 & 7.709 & & - \\
\hline
\end{tabular}


Gewone Dienst

\begin{tabular}{|c|c|c|}
\hline$\frac{100}{100}$ & $\frac{1.900}{191}$ & $i_{i 2}$ \\
\hline$\because 4447$ & $150,7 \%$ & 4021903 \\
\hline 50040 & 550050 & 5409060 \\
\hline - & . & $\cdots$ \\
\hline 24259 & 4205 & 76.914 \\
\hline 0.2611 & 102050 & 591101 \\
\hline
\end{tabular}

\begin{tabular}{|c|c|c|}
5375076 & 000003 & 0525009 \\
7306193 & 1066005 & 11602037 \\
\hline 30000 & 30000 & -
\end{tabular}

$55 \% 7977$

659297110050769

17133579

17422503

2356049

$27 \quad 24922$

$9210 \% 520$

$19030 \quad 320$

9921676

9195005

$21 \quad 422=5$

22,135

3515600

552090

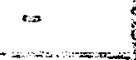

55000

$\$ 102500$

110519304

1737989

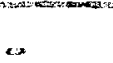

92133500

14353153

17252402

1380990

17431744

$22920 \geq 0$

$2955995 ?$

700700

2570192

2816463

$359+320$

4050723

15321801

$17 \div 33900$

$2 \div 718997$

426337

1.451701

1173506

1306545

2600425

$3640 \quad 050$

72097809

$93733308 \quad 127 \% 45556$

10467892

12041351

12203070

1362500

$156530 \%$

13993579

1341613

6175098

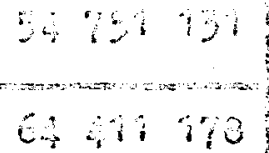

16848791

3923300

16175098

405073
4253574
26004925
3600053

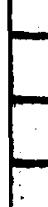

$\frac{3923}{18573560}$

20644752

$157 \quad 465591$

15059530

1391300

5645325

67919460

\begin{tabular}{|l|l|}
\hline 56195340 & 77000889 \\
\hline
\end{tabular}

27 iE2 $17^{2}$

4579905

491304729

\begin{tabular}{l|l}
8330407 & 7430586
\end{tabular}

25042275

\begin{tabular}{ll|l}
550314423 & 682743521
\end{tabular}

$928 \quad 333 \quad 171$ 


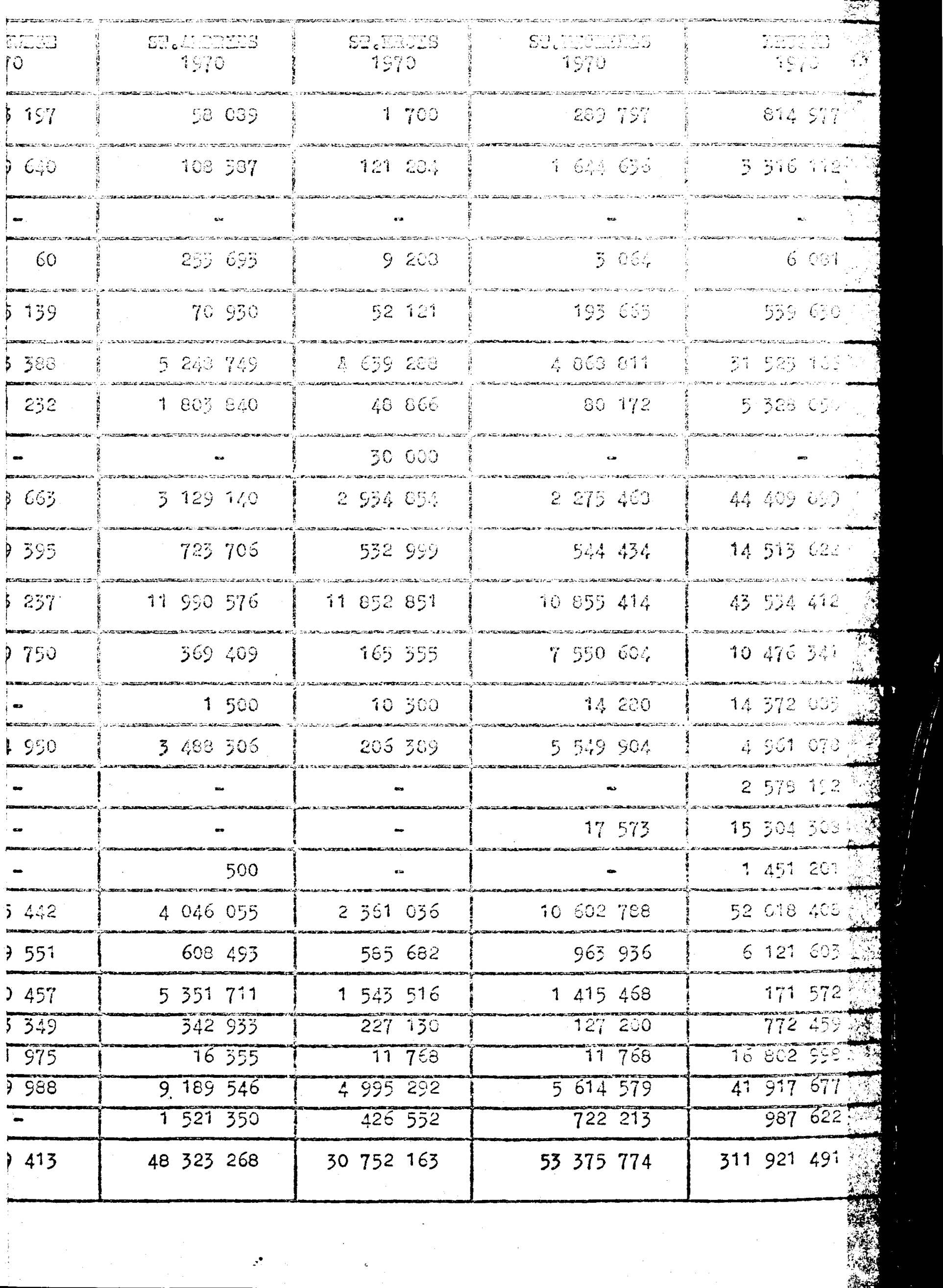


BRUGGE

$\Lambda_{-6}^{2} 0500=$

$13: 20=0 \quad 502000$

Ionotes:

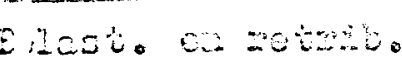

(1)

Vexase $=2 \operatorname{sen}$

16

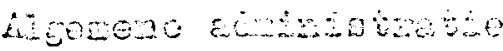

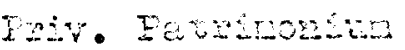

A3 300000000000

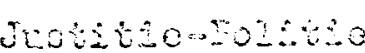

Sunation:

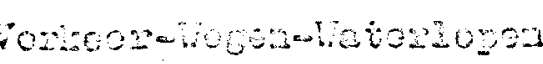

2.00300000000

800000001

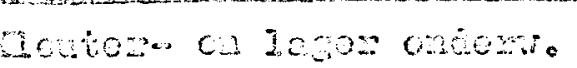

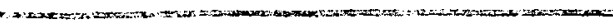

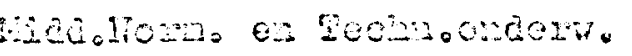

sunstozeconja

308020 $0500 \leq 1 \leq i 0$

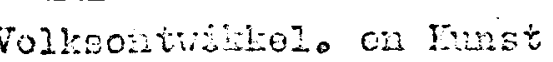

Erediezst

Sociele Vosmi。 en crderst.

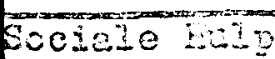

Gerozoneicseave

ppervaze

Suisvesring-siecedou

POPAaI
$258+20.0$.

550

99302

74956

20,002

1970

$190 \%$

16936

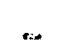

485

6497

5099677

4393

50

$\because 45112$

a.

203579

8069

611576

90,060

30119

19795

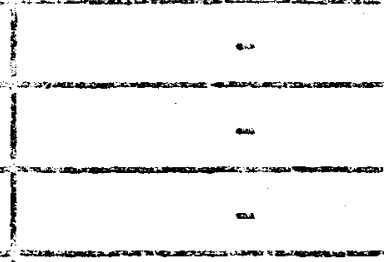

2637270

1786796

3356677

368752

$\frac{1955}{4039843}$

14039843

$87^{10} 0.5$

31945993

345524

3950

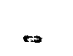

$95+17$
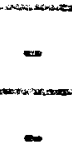

$155 \quad 84$

81988

2000

21385
$\mathrm{LuCRO}$ 198

589

$92 \div 2$

2162

496035

50

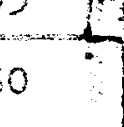

$\frac{39499}{594}$

$\because 015235$

52102

$32 \div 095$

27096

11

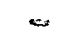

$\rightarrow$

.

..

$47 \quad 963$

159551

149550

\begin{tabular}{|r|}
9300 \\
\hline 703132 \\
\hline 3355953 \\
\hline-
\end{tabular}




\begin{tabular}{|c|c|c|c|c|}
\hline 110 & 50,0 & 20,1 & 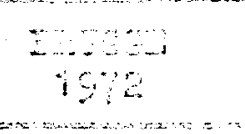 & $200 . \cdot 3$ \\
\hline 15.24 & ianis & 12,0 & 6,05 & 30,1 \\
\hline$C, 6, t$ & bess & 4068 & $\therefore 600$ & 26.60 \\
\hline$\cdots$ & 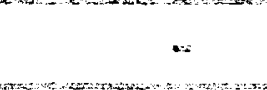 & - & - & -3 \\
\hline 0,12 & $23 \equiv$ & 0,0 & 0,65 & 0.46 \\
\hline 10,49 & 8.65 & 0,81 & 0,0 & 5,0 \\
\hline 62.56 & 46.6 & $0,3,0$ & 725,34 & 50,70 \\
\hline 103,5 & 63,0 & 50.98 & 22,80 & $760: 00$ \\
\hline- & 0,26 & 0,26 & $\therefore$ & $\infty$ \\
\hline 862,95 & 1936 & 560,44 & $79, \div 2$ & $20 b_{5}<5$ \\
\hline 202,02 & $147,8 \%$ & $1 / 8,63$ & 02,0 & $6,0,15$ \\
\hline 845,94 & 7958.37 & 846,4 & 5843 & 30,63 \\
\hline 203,57 & 164,19 & 122,15 & 1968 & 52,25 \\
\hline 279,27 & 124,23 & $1,7,10$ & 60,62 & 3,6 \\
\hline 96,40 & 150,40 & 195.60 & 200,46 & $3,8,86$ \\
\hline 50,10 & 22,24 & $2+, 5$ & $50 \%$ & 25.6 \\
\hline 297,33 & 132,60 & 352,02 & 105,63 & 20,0 \\
\hline 23,20 & 12,53 & 10,01 & 16,07 & 30,60 \\
\hline 010,79 & 622,05 & 799,64 & $\begin{array}{ll}1 & 0.2,39\end{array}$ & i $c 03,02$ \\
\hline 118,95 & 90,52 & 104,15 & 113,57 & $i 34, c$ \\
\hline 3,33 & 103,63 & 13,35 & 14,37 & 11,72 \\
\hline $55,0 !$ & 16,07 & 33,47 & 52,32 & 47,54 \\
\hline 326,51 & $145,3 ?$ & 158,45 & $17+92$ & 220,76 \\
\hline 814,52 & 585,01 & 479,40 & $652, \div 1$ & $82 z_{3}, 5$ \\
\hline$: 9,19$ & 35,52 & 71,13 & 63,43 & 210,50 \\
\hline 051,08 & 4239,00 & $469,4,71$ & 5724,83 & $78 i \varepsilon, 27$ \\
\hline $\begin{array}{l}308,30 \\
, 08 \%\end{array}$ & $\begin{array}{l}1603,24 \\
37,82 ?\end{array}$ & $\begin{array}{l}1659,59 \\
35,35\end{array}$ & $\begin{array}{l}2155,41 \\
37,25 \%\end{array}$ & $\begin{array}{l}3119,74 \\
39,90 \%\end{array}$ \\
\hline
\end{tabular}


JESE

1970

73.45

$17,03 \quad 6,6 \%$

0,03

2.31

$50=58$

0,55

-

7,4

$35 \div 2$

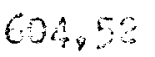

22,39

-

67497

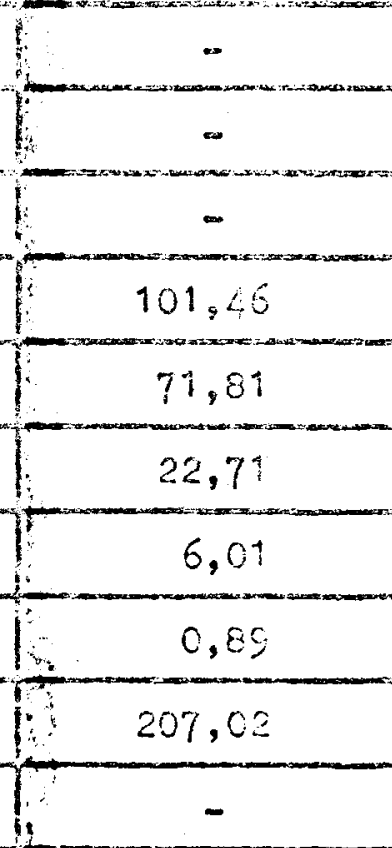

2218,45

409,90

18,48
3.54

$-$

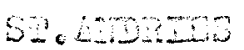

1970

1586

$\therefore: 3$

$\because 20,12$

710,02

-

190,83

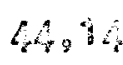

73,51

22,53

0,09

212,75

ris

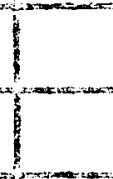

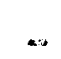

$$
0,03
$$

246,77

37,11

326,40

20,92

$-2$

5

5

1,00

560,47

92,79

2947,26

1285,46

$43,62 \%$

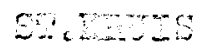

1970

$$
0,5
$$

$9, \mathrm{CH}$

0.69

3,89

3.5975

$3,6+5$

2,24

218,71

2972

093,29

12,52

$0.7 \%$

15.58

$-$

$=$

175,95

43,65

145,02

16,55

0,58

372,26

31,79

2291,69

756,18

33,00 conombs

19,10

23,11

12509

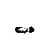

0,25

$16: 0$

$5 \%$ i 6

6.12

173.62

4,54

830.5

$5 \%, 18$

1.09

423,46

$1,3 i$

-

809,00

75,55

103,00

9.71

0,90

428,40

55,11

4072,52

1484,67

$36,45:$ 


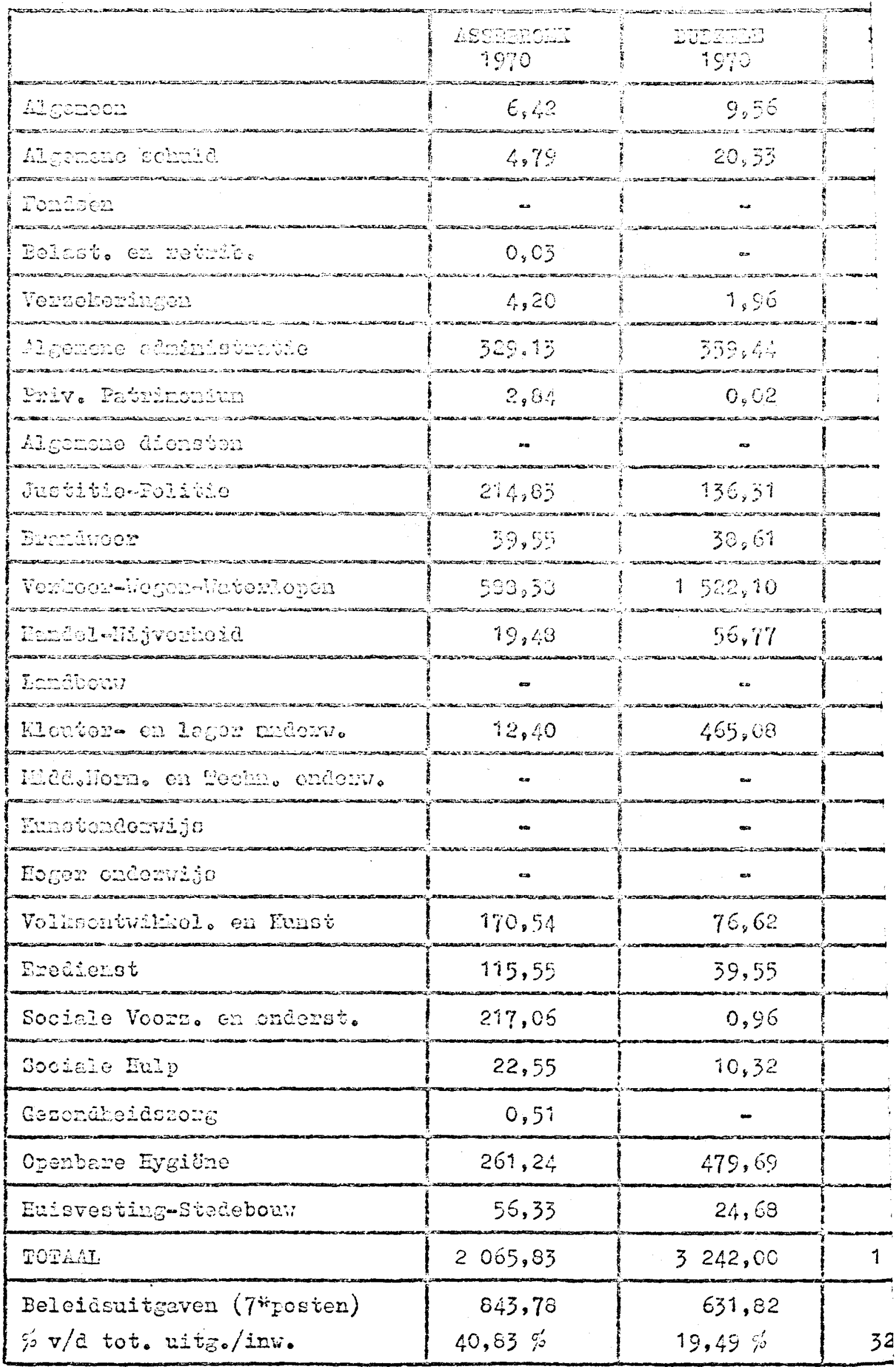




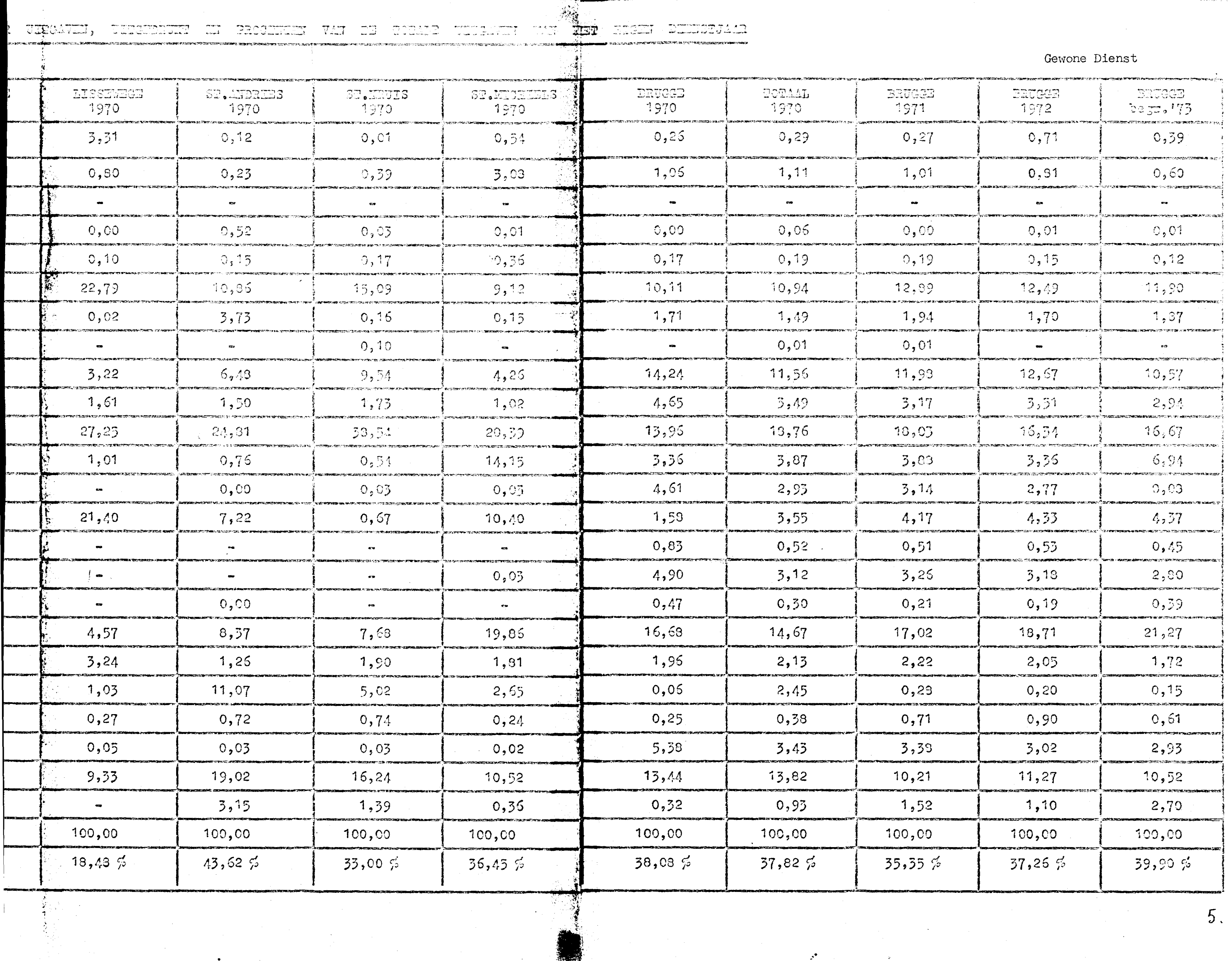


BRUGGE

\begin{tabular}{|c|c|c|c|}
\hline & $\begin{array}{c}25,200 \mathrm{X} \\
1070\end{array}$ & $\frac{2000}{1970}$ & 8009 \\
\hline Angases & 0,51 & 0,29 & 0,02 \\
\hline 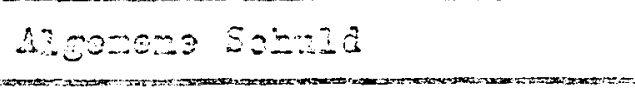 & 0,23 & 0,63 & 2,75 \\
\hline Iondeon & - & - & - \\
\hline $202054,0200+26$. & 0,00 & - & - \\
\hline $70 x=020 x=000$ & 0,20 & 0,05 & 0,05 \\
\hline 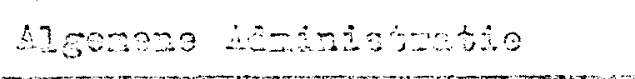 & 15,33 & 11,03 & 14,83 \\
\hline 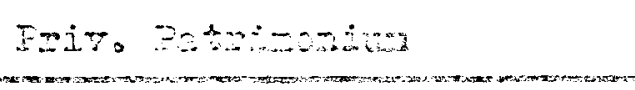 & $0,1,8$ & 0,00 & 0,0 \\
\hline 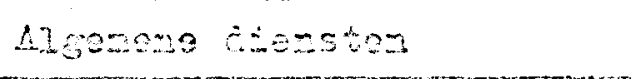 & - & - & - \\
\hline $5025+3 \pm 0-202120$ & 10,10 & 4,20 & 8,31 \\
\hline 000020000 & 1,91 & 1,19 & 1,50 \\
\hline 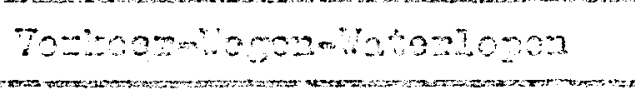 & $\infty, 63$ & $4.5,63$ & 9,72 \\
\hline Vnano?-7tsromota & 0,91 & 1,73 & - \\
\hline $\operatorname{Inn} \theta \sin$ & $\cdots$ & - & - \\
\hline 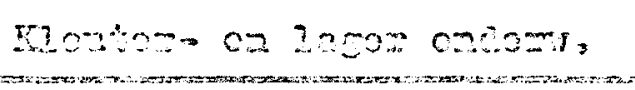 & 0,60 & 11,35 & 20,43 \\
\hline 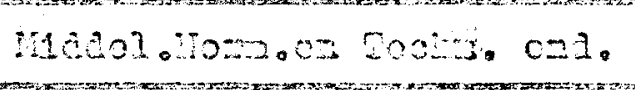 & - & - & $\cdots$ \\
\hline 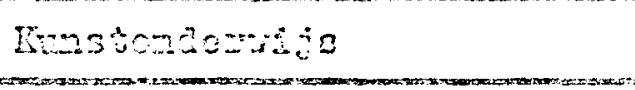 & $\therefore$ & - & - \\
\hline Hose: cacosonds & - & - & - \\
\hline 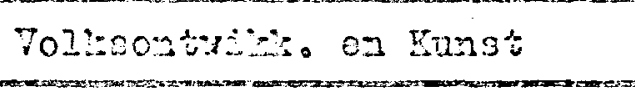 & 0,25 & 2,35 & 1,11 \\
\hline Brodions? & 5,59 & 1,22 & 4,79 \\
\hline 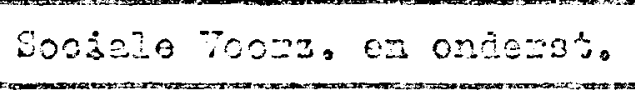 & 10,51 & 0,03 & 4,43 \\
\hline Sosi210 5212 & 1,09 & 0,32 & 0,23 \\
\hline Gazoudbe $26 s=0=3$ & 0,02 & - & 0,00 \\
\hline Opezvase Ejgisns & 12,55 & 14,80 & 21,23 \\
\hline E2:5725\%:=5 - 560203025 & 2,71 & 1,05 & - \\
\hline TOTAL & 100,00 & 100,00 & 100,00 \\
\hline Beleicisnitzarou in $\%$ & $40,83 \%$ & $19,49 \%$ & $32,23 \mathrm{c}$ \\
\hline
\end{tabular}


BRUGGI

Inkonsten en uitgaven per jnwoner vós en na de fusie.

(1)

\begin{tabular}{|c|c|c|c|c|c|c|}
\hline & \multicolumn{3}{|c|}{ Totaal eigon diunstjasr } & \multicolumn{3}{|c|}{ Algcraen totaal } \\
\hline & $\begin{array}{l}\text { Vastgest. } \\
\text { rechton }\end{array}$ & $\begin{array}{l}\text { Vantgust. } \\
\text { uitgeven }\end{array}$ & $\begin{array}{l}\text { Pos. of } \\
\text { nog. saldo }\end{array}$ & $\begin{array}{l}\text { rastgest. } \\
\text { rechten }\end{array}$ & $\begin{array}{l}\text { Vastgest. } \\
\text { vitgaven }\end{array}$ & $\begin{array}{l}\text { Pos. of } \\
\text { reg. saldo }\end{array}$ \\
\hline 1970 & & & & & & \\
\hline Asscbroek & $2.748,7$ & $2.435,3$ & $+\quad 313,4$ & $4.082,4$ & $3.400,7$ & 681,6 \\
\hline Brugge & $1.335,0$ & $1.650,2$ & $-315,2$ & $3.158,8$ & $3.025,8$ & 133,0 \\
\hline pudzele & 263,2 & $1.228,6$ & $-965,4$ & $4.196,0$ & $4.457,5$ & $-261,5$ \\
\hline koolkerke & $5.315,8$ & $10.438,3$ & $-5.122,5$ & $5.603,7$ & $10.751,1$ & $-5.147,4$ \\
\hline Lissewege & - & 471,1 & $-471,1$ & 664,1 & 471,2 & $+\quad 192,9$ \\
\hline St. Andries & $2.788,0$ & $2.818,3$ & 30,3 & $3.864,5$ & $3.629,1$ & 235,4 \\
\hline St. Kruis & $1.530,6$ & $1.689,7$ & $1.59,1$ & $2.001,3$ & $1.908,9$ & 92,4 \\
\hline St. Michiels & $2.261,7$ & $2.221,6$ & 40,1 & $9.132,2$ & $8.742,1$ & 390,1 \\
\hline Gemiddelde & $1.873,2$ & $2.099,1$ & 220,9 & $3.946,9$ & $3.789,1$ & 157,8 \\
\hline 1971 & & & & & & \\
\hline Groot-Brugge & $2.876,0$ & $2.934,3$ & 58,3 & $4.896,0$ & $4.405,2$ & 490,8 \\
\hline 1972 & & & & & & \\
\hline Groot-Brugge & $5.772,0$ & $5.868,6$ & 96,6 & $8.689,0$ & $8.339,7$ & 349,3 \\
\hline
\end{tabular}

(1) Gemeenterekeningen 1970-1971-1972, Stad Brugge. 


\begin{tabular}{|c|c|c|c|}
\hline Funktie & 1971 & 1972 & stijging \\
\hline Algemene administratie & 27.957 .704 & 56.397 .550 & $102 \%$ \\
\hline Handel en nijverheid & 5.058 .445 & 110.000 .000 & $+2.070 \%$ \\
\hline $\begin{array}{l}\text { Kleuter en lager } \\
\text { onderwijs }\end{array}$ & 8.652 .954 & 24.838 .900 & $184 \%$ \\
\hline Hoger onderwijs & 1.114 .612 & 17.000 .000 & $+1.426 \%$ \\
\hline $\begin{array}{l}\text { Volksontwikkeling en } \\
\text { kunst }\end{array}$ & $16] .622 .293$ & 220.860 .782 & $30 \%$ \\
\hline Eredienst & 8.210 .490 & 25.146 .143 & $206 \%$ \\
\hline Gezondheidszorg & 1.500 .000 & 19.993 .000 & $+1.232 \%$ \\
\hline Afvalwater & 7.287 .650 & $5] .940 .850$ & $612 \%$ \\
\hline Huisvesting en stedebouw & 7.193 .802 & 49.147 .814 & $582 \%$ \\
\hline
\end{tabular}

Voor 1971 totaliseerde Brugge in de buitengewone dienst een uitgave van 346.315.820 $\mathrm{F}$ (eigen dienstjaar). In 1972 bedroeg dit cijfer reeds 696.836.976 $\mathrm{F}$, wat een procentuele stijging van 101 \% betekent. 
Bijlage 3

FINANCIELE GECENASS TER ONDERSTEUNTNG VAN

HET DOELEINDINONDTRZOEK.

A. KORTRIJK

B. LEUNEN

C. KESSEL-IO

D. HERENT 
FORTRUK Gevone dinist

UTTGAYTSE PER IFEOMER EN IN PROCENTEN VAN DE UITGAVEN VAN HET EIGEN DIENSTIAAR

\begin{tabular}{|c|c|c|c|c|c|c|c|c|}
\hline \multirow[b]{2}{*}{ FULTIES } & \multicolumn{2}{|c|}{ Raping I975 } & \multicolumn{2}{|c|}{ PEWING I972 } & \multicolumn{2}{|c|}{ BEGROTING I973 } & \multicolumn{2}{|c|}{ BEGROTING I974 } \\
\hline & Per I. & In 8 & Per I. & $\operatorname{In} \%$ & per I. & In $\%$ & Per I. & In $\%$ \\
\hline ATreneen & 14.93 & 0.24 & 12,37 & 0,19 & 16,48 & 0,19 & 25,50 & 0,27 \\
\hline A2sengeseschida & 50.25 & 0,3 & 5019 & 8,74 & 50,60 & $0,5 y$ & 5c, $7 c$ & 0,53 \\
\hline \multicolumn{9}{|l|}{$\operatorname{con} 0 \mathrm{er}$} \\
\hline Belusures en retributies & 5,37 & 0.01 & 0.41 & 0,01 & 0,58 & 0,01 & 0,59 & 0,01 \\
\hline Vecestententen & 4.03 & 6,1 & 19.81 & 0,73 & 56,07 & $c, 65$ & 65,17 & 0.68 \\
\hline Alrespe aduindetratie & 543,10 & 3.91 & $5,4,93$ & 854 & 726,04 & 8,44 & 815,30 & 8.56 \\
\hline exvect rémimonivm & 43,91 & 2,22 & 15.59 & 2,3 & $45 x^{\circ}$ & 2,19 & 221,89 & 2,33 \\
\hline Alocong dicoten & 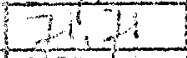 & 1.16 & -7.33 & 1,05 & $114+72$ & 1.33 & 112,92 & 1,19 \\
\hline $30+121 \mathrm{e}-\mathrm{poj} 1 \mathrm{eje}$ & 8504 & 23.28 & 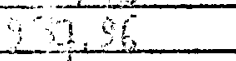 & 13,63 & 1.16512 & 13,54 & $1.276,70$ & 13,40 \\
\hline Eronegeor & 232,31 & 3.74 & 246,42 & 36 & 374,55 & 4,35 & 441.74 & 4,64 \\
\hline Wricer-Wesen-Waterlopen & 903,30 & 34,55 & 960,48 & 14,02 & $1227 \cdot 12$ & 14,26 & $1.334,50$ & 14. o1 \\
\hline 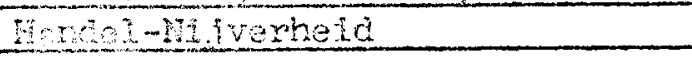 & 358,19 & 5,71 & 355.24 & 5,18 & 390,48 & 4,54 & 504,56 & 5,30 \\
\hline \multicolumn{9}{|l|}{ Encons } \\
\hline 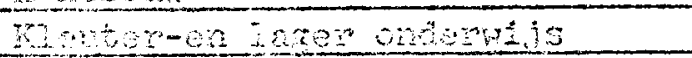 & 1064 & 4,62 & $10 C_{4}=5$ & 1,56 & 134,82 & 1,57 & 139.65 & 1,47 \\
\hline 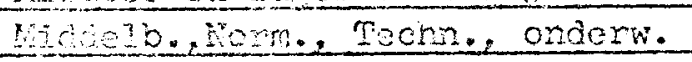 & 228,4 & 3.69 & $261+45$ & 3,52 & 305,63 & 3.59 & 350,38 & 3,68 \\
\hline Finvondempis & $36 \sqrt{5}$ & $5.0 \%$ & 366,63 & 535 & 42,86 & 5.48 & 499,15 & 5.24 \\
\hline Koner conderwis & $5 \cdot 1$ & 0,0 & 5.83 & 0,08 & 5,3 & $0,0.7$ & 5.34 & 0,06 \\
\hline 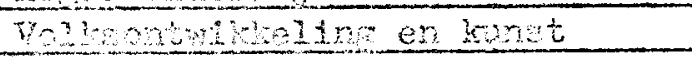 & 1 30,16 & 253 & 913,2 & 234 & 1266,56 & 14.72 & $1.341,08$ & 14,08 \\
\hline Enedsenge & 10.9 & 1,8 & $12 y+10$ & 1,8 & 155,14 & 1,80 & 14. 93 & 1.55 \\
\hline Socjale voomarg en onderstand & 235,58 & 4.23 & 316,02 & 4.61 & 411,85 & 4,78 & 619,22 & 6,50 \\
\hline Sossoge hu3o & .3 .51 & 0,30 & 1901 & 0.25 & 39,96 & 0,46 & 41,95 & 0,44 \\
\hline Geronghe desong & 3848 & 0,0 & 6.26 & 0,6 & $57+02$ & $c, 66$ & 58,57 & 0,6 \\
\hline Wopevoesing en weter & 5920 & 247 & 25,1 & 2.71 & $192+15$ & 2,23 & 206,45 & 2,17 \\
\hline 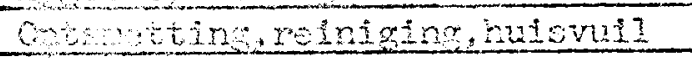 & 2559 & 4,12 & 21703 & 4,6 & $38 \div 20$ & 4,42 & 525,16 & 5,51 \\
\hline 106085 & 90.9 & 1,46 & 103.37 & $1.4 i$ & 199,92 & 2,32 & 185,18 & 1.98 \\
\hline 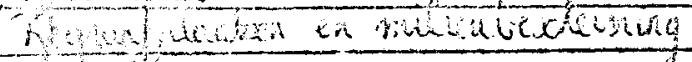 & 21.75 & 1.16 & $7+1$ & $i d_{i}$ & 85,15 & $c, 99$ & 88,82 & 0,93 \\
\hline hav sédting es stedebouw d & 46203 & $7+4$ & 37901 & 8,45 & 586,92 & 6,82 & 463,58 & 4,86 \\
\hline 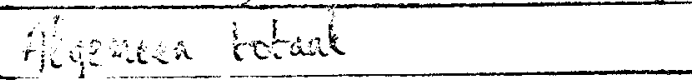 & $6.206,68$ & 100 & $6.85,3$ & 100 & $8.605,97$ & 100 & $9.525,58$ & 100 \\
\hline 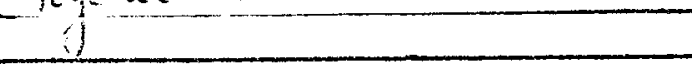 & & & & & & & & \\
\hline
\end{tabular}




\begin{tabular}{|c|c|c|c|c|c|c|c|c|}
\hline \multirow[b]{2}{*}{ EUNCTIES } & \multicolumn{2}{|c|}{ RENENING I97I } & \multicolumn{2}{|c|}{ RENEIING I972 } & \multicolumn{2}{|c|}{ BEGROTING I973 } & \multicolumn{2}{|c|}{ BEGROTING I974 } \\
\hline & Per $I$ & In $\%$ & Per $I$. & In & per I. & In $\%$ & Per I. & In \% \\
\hline Argemeen & 6,15 & 0,15 & 6.23 & 0.43 & 7.37 & 0,12 & 4,56 & c.20 \\
\hline Algemene schuld & 214 & 0,60 & 4,2 & 8,37 & $4 \sqrt{20}$ & 0,28 & 11,23 & $-0,25$ \\
\hline \multirow{2}{*}{\multicolumn{9}{|c|}{ Bondsen }} \\
\hline & & & & & & & & \\
\hline Veromeringen & 31,36 & 9.80 & $\sqrt{64}$ & 0.89 & 46,16 & 016 & 55,12 & 0,8 \\
\hline Algemene adiningtratie & 52.30 & 22,3 & 3452 & 12.49 & $-71,52$ & 11.4 & 307.21 & 11,80 \\
\hline Quivat petimoniun & $12^{4}$ & 2.3 & 3512 & 2.06 & 25152 & 2.50 & 18544 & 3.71 \\
\hline Algemene diensten & 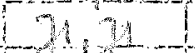 & $4+67$ & 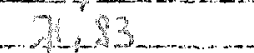 & 2.56 & 1248 & 1.85 & 110,68 & 1,62 \\
\hline Justitie politas & 35 & 39,12 & $21+22$ & 12,86 & $A, 240,22$ & 18,89 & 1. 253,33 & 18,33 \\
\hline Brandwees & $15 y$ & 36 & $1589^{6}$ & 3.36 & 25365 & 47 & 32458 & 4,75 \\
\hline Temberwoger-weterowen & 21 & 1908 & 934,5 & 484 & 0.0492 & 1722 & 1.14101 & 16.69 \\
\hline Iondel-uiverineid & -13163 & -323 & -4676 & $-3,6$ & $-142,26$ & $-2 \times 35$ & $-31,94$ & -147 \\
\hline \multicolumn{9}{|l|}{$I-$ diboun } \\
\hline Weuter-en 2 ager ongery 19 & 30,14 & 9.95 & 4215 & 0.9 & 60113 & 0.99 & 56,15 & 0,82 \\
\hline Middebo. Numin seche onderiv & 33,96 & 122 & $-81,05$ & 1.15 & 99.47 & 1,64 & 87.89 & $1+21$ \\
\hline Konstonderwis & 310 & 2.36 & 40197 & 2,33 & 154,60 & 2,55 & $230+14$ & 1,90 \\
\hline Hogen ondermijs & 5.21 & 0.13 & 5,3 & 0.13 & 5,33 & 0,10 & $5+84 \ldots$ & 0,02 \\
\hline Volksontwikeling en must & $6+16$ & d5 50 & -3393 & 15.86 & 4.83344 & 17.03 & $1.080,4$ & 15,80 \\
\hline Eredienst & 1041 & 2.68 & 12642 & 2.3 & 15348 & $2 ! 53$ & 146.33 & 2,17 \\
\hline Sociale voonzop en onderstand & 39,5 & $6 g^{2}$ & 316,22 & 6,83 & 4185 & 6.74 & 61697 & $9+02$ \\
\hline Soctale hulp & $1 \times 3$ & $a_{-2} y^{2}$ & 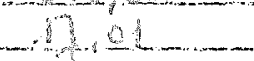 & 0,37 & 39.96 & 0,66 & $41,95^{1}$ & 0,61 \\
\hline Gezondheldszon & 135 & 0,32 & 12,90 & 0.30 & $12,0 \%$ & 0,28 & 19,17 & 0,28 \\
\hline Hyoiene, voecing en water & 125.94 & 28 & $-48,94$ & 3.31 & 11969 & 1,92 & 135,29 & 1,98 \\
\hline ontenetringereinioing, huisvuil & 265.98 & 5,95 & $3+, 92$ & 6.96 & $36 \Omega 94$ & 6,0 & 404,21 & 591 \\
\hline 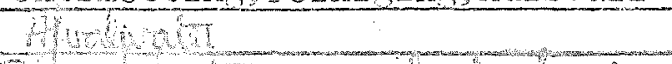 & $8+1^{2}$ & $2,0,3$ & 99,09 & $2 \sqrt{4}$ & $A 51,25$ & 240 & 141,26 & 2,07 \\
\hline 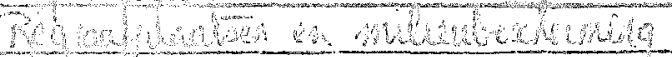 & 21 & 2,73 & 214 & 0.47 & 25,27 & 0,4 & $2.66^{1}$ & 042 \\
\hline 1 lebesting en stedeboum 1 & $27 \cdot 3$ & 0,64 & 22,6 & 0.49 & 39,19 & 0,65 & 67,97 & 0,99 \\
\hline 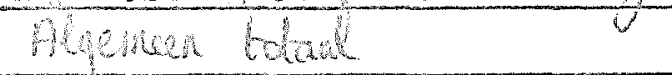 & $4.302,34$ & 100 & 4.622 .32 & 200 & 6.067 .13 & 100 & $6.839,16$ & 100 \\
\hline 10 & & & & & & & & \\
\hline
\end{tabular}


Beiastingen en retributies verzeleringen

Alsemene administratio Privaet potntmoniun

Azgemene diensten

\begin{tabular}{|c|c|c|c|}
\hline PER & $M E E L$ & WERK & KOSTE \\
\hline $\operatorname{ler} I$. & In $\%$ & Per I. & In $\%$ \\
\hline & & & 0,06 \\
\hline & & & \\
\hline & & & \\
\hline 53 & 5 & 34,54 & 3.06 \\
\hline & $A 5,04$ & 420.5 & 10.68 \\
\hline & $-4 \quad \sqrt{4}$ & 28 - & \\
\hline 5 & 0,28 & 94.40 & .8 .89 \\
\hline 1.002 .3 & 26,44 & 9564 & $-3,73$ \\
\hline 269.13 & 6,99 & $-83+2$ & -736 \\
\hline & $-6.26-$ & 243.2 & 2.71 \\
\hline
\end{tabular}

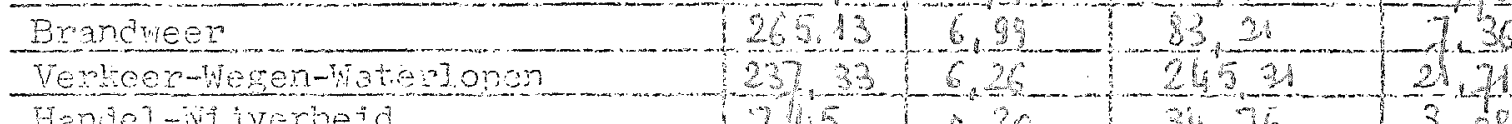

Irengel-itiverheja

T, - ndbouw

$-745+2,20-34,76-3,08 \ldots$

\begin{tabular}{|c|c|}
\hline OUER DAACHTEN \\
\hline EI I. & In \% \\
\hline 0,02 & 0,00 \\
\hline 0,59 & 0,09 \\
\hline 0,26 & 0,04 \\
\hline 1,28 & 0,19 \\
\hline
\end{tabular}

SCHULD

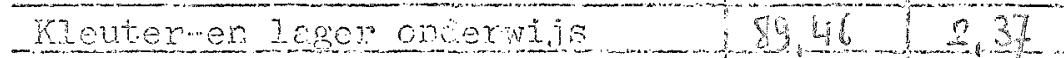

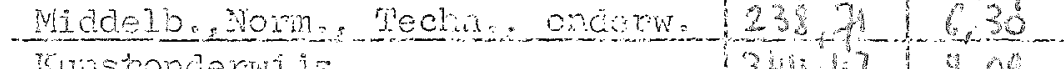

ronstonderuije

Fogen onderwio

Volksontwikejing en junst

$34,4905-143$

Eredienst

Sociale voorzoug en onderstard

Soosale husp

Gezondheldszon?

Hyriene, yoeding en water $47002 / 1264] 2093$ 4.33

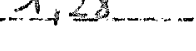

5,23 $0,19 \ldots$

\begin{tabular}{|l|l|}
\hline \multicolumn{2}{|c|}{ SCHULD } \\
\hline Per I. & In $\%$ \\
\hline 15.78 & 0,53 \\
\hline 50,160 & 1,68 \\
\hline & \\
\hline
\end{tabular}

otsmetting reinising, huisvuil Workenta.

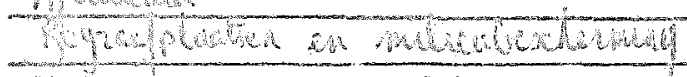
WuLvestrng en steaebour

Mromen beral

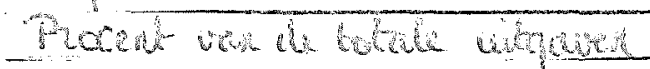

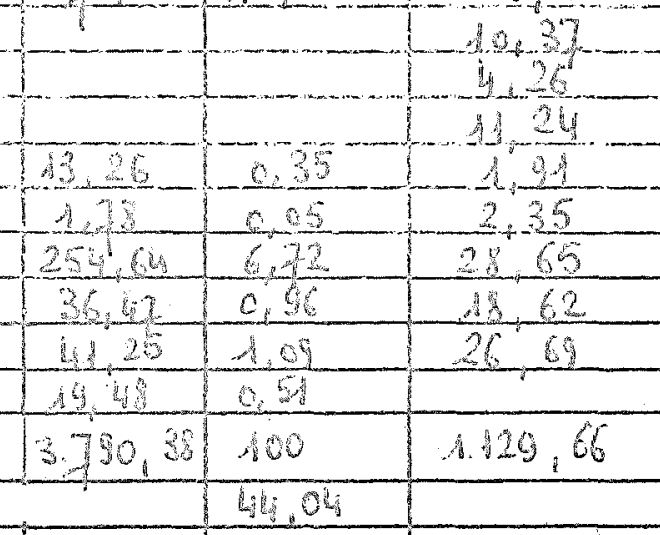
2,54

1]. 93 $3.25-\frac{31}{1}+12$ \begin{tabular}{l|l}
5,83 \\
184 \\
4934
\end{tabular} - .92 82.17 $-\frac{0.38}{0.9}$ 40,59 $-0,7,7$

$10,89-\frac{1,17}{0,36}$

$12,75,0,42$ $62,55 \quad 2,09$
-26 $26,21 \quad 0.87$ $744-47-24$
-73 $34304-147_{42}^{2}$

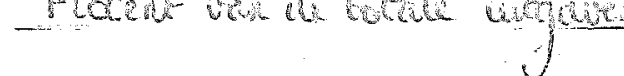

\begin{tabular}{|l}
0,99 \\
0,41 \\
0,21 \\
\hline 2,51 \\
\hline 2,36 \\
\hline 100 \\
\hline 13,13
\end{tabular}
3.91

13,46

681,13

1,98

100

34,92 


\begin{tabular}{|c|c|c|c|c|c|c|c|c|}
\hline \multirow{2}{*}{ FUNOTIES } & \multicolumn{2}{|c|}{ PESSBMELL } & \multicolumn{2}{|c|}{ WERKINGSKOSTEN } & \multicolumn{2}{|c|}{ OVERDRACHTEN } & \multicolumn{2}{|c|}{ SCHULD } \\
\hline & Per I. & $\operatorname{In} \%$ & Per $I$. & In $\%$ & per I. & In $\%$ & Per I. & In $\%$ \\
\hline Aigeneen & & & 0,6 & 0.0 & 0,02 & $0, \infty$ & 28,80 & 0.80 \\
\hline Alremene schuld & & & & & & & 50,76 & 1,63 \\
\hline Tondsen & & & & . & & & & \\
\hline Belestingen en retributies & & & & & 0,59 & 0,06 & & \\
\hline Venelentingen & -2432 & 0.5 & 40,43 & 4,03 & & & & \\
\hline Algemene adniniscretie. & 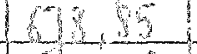 & 45,20 & 1079 & 199 & 0.26 & $.0,03$ & 28,21 & 0,91 \\
\hline Pxvaet petrinosing & 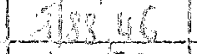 & $4+22$ & $22 \cdot 54$ & 221 & & & 10.89 & 0,35 \\
\hline Alsenene dienten & 30.59 & 0,24 & 29.5 & -94 & & & 23,68 & 0.76 \\
\hline Justitie Poitie & ABSG & 2580 & $4+6+8$ & 225 & 4,27 & 0.13 & 64.63 & 2,08 \\
\hline Erancheer & 343,25 & Dof & 9240 & 6,9 & & & 39,39 & 1,27 \\
\hline Tenteen wesen-ilatenlopon & 242 or & 6.54 & 204 & 2068 & & & 837.59 & 2697 \\
\hline HendeI-Ni verbeia & 5 & $0+13$ & $2=, 13$ & $2: 3$ & 34.41 & 3,26 & 640,51 & 14,3 \\
\hline I-nobouid & & & & & & & & \\
\hline Klenter-en lager oncerwis & $96+3$ & 2.13 & 10,23 & 1,03 & 19.10 & 1,98 & 13,48 & 0,43 \\
\hline MiddeIb. Nonm. Techne onderw. & $28+2$ & 644 & 24,00 & 2,42 & 5,50 & 0.57 & 33.26 & 1,07 \\
\hline Kunstonderwas & 4029 & 9 & 24,3 & 26 & 1,12 & 0.12 & 25 & 217 \\
\hline Woger onderwis & & & & & 514 & $-a, b$ & & \\
\hline Volksontwikleling en bunst & 24.66 & 12,12 & A36, 32 & $.3,36$ & 122,53 & 1272 & 510,71 & 16,46 \\
\hline Eredienst & 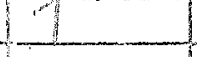 & & 6.6 & 0,6 & 3346 & 86 & 38,45 & 1,88 \\
\hline Soelale voonzong en onderstand & & & A, d & 0,10 & 619 & 64,15 & & \\
\hline Soojale bulp & & & 5.65 & 0,5 & 36,30 & 3,27 & & \\
\hline Gerondbetdezon & $-46,42$ & 0,35 & 0.6 & 0.07 & 213 & 0,26 & 39,41 & 1,27 \\
\hline Evgiene, voeding en water & 2,83 & 0.4 & 2,35 & 0.24 & & & 202,16 & 6.51 \\
\hline Ontsnetting, reiniging, huisvul & 285,61 & 640 & 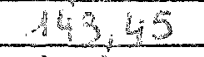 & 1448 & 4,0 & 0,42 & 92,02 & 2,96 \\
\hline Aleding & 48,38 & 1.0 & 4,6 & 0,6 & & & 135,20 & 4.35 \\
\hline 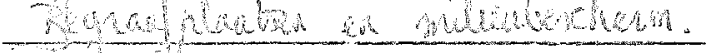 & 4829 & $40 y$ & 217 & 2,19 & & & 18,82 & 0,61 \\
\hline Hut yedorng en stedebour & $2+80$ & 0.69 & & & 3,46 & 3.26 & 410,32 & 13,21 \\
\hline Alawhe lotad & 4.465 .75 & 100 & 990.75 & 100 & 963,62 & 100 & $3.105,47$ & 100 \\
\hline 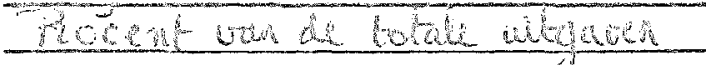 & & 46,88 & & 10,40 & & 10,12 & & 32,60 \\
\hline
\end{tabular}


Aremest

sponuld

Betabturen en retributtes Vergeteresneres

Alserene adminatretio

Buvat petrimonim

Alecuene densten

Sustete-poltse

Bronenger

Werteer-heren-Meteraven

Aenole-13 iverhetd

S. nowoury

Meutersen Iager onderwa

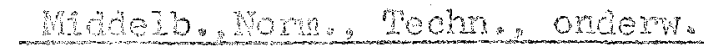
monongervets

Foner onespry is

Wolnontwineding en hust

Fredienet

Sooinle voomzro en onderstand

soctan huld

Berondhetasroge

Bratene voeding en water

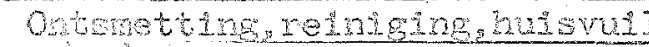

- Hosestes

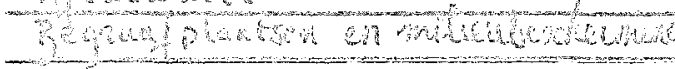

Husvestno en atedebour

Azeneen totad

(a)

\begin{tabular}{|c|c|c|c|}
\hline BEGROMTNG & I973 & EEGRONING I & \\
\hline ber $I$. & $\operatorname{In} \%$ & Per I. & In $\%$ \\
\hline 496,57 & 1,65 & 196,46 & 1,52 \\
\hline 154,05 & 429 & 148,21 & 1,16 \\
\hline- & - & - & - \\
\hline 0.32 & 0,00 & 0,32 & 0,00 \\
\hline 30,60 & 0.33 & 49,25 & 0,38 \\
\hline .5339 & A3, 04 & 177341 & 1321 \\
\hline 206,42 & 4,73 & $28 \sqrt{64}$ & 217 \\
\hline 238,22 & 2.00 & 33238 & 2.57 \\
\hline 146420 & 12,29 & $1.648,26$ & 1273 \\
\hline 78486 & 6.63 & 885,69 & 6,34 \\
\hline 2058.47 & 18.95 & $2.315,12$ & 17.98 \\
\hline 35.24 & 0,30 & 44,08 & 0.34 \\
\hline 5.42 & 0.05 & $5 \cdot 15$ & 0,04 \\
\hline 478.76 & 4.02 & 75.05 & 0,58 \\
\hline 74.95 & 0.02 & 1,61 & 0,0 \\
\hline 497,17 & 4,47 & 505,66 & 391 \\
\hline$r_{-\infty}$ & - & - & - \\
\hline 1.630 .72 & 1369 & $2.019,10$ & 1567 \\
\hline 35,93 & 0,30 & 46,08 & 0.36 \\
\hline 653,54 & 5,48 & 703,52 & 543 \\
\hline 413 & 0,94 & 61,64 & 0.48 \\
\hline 45.59 & 0,35 & 42.03 & 0,63 \\
\hline 110,09 & 0,92 & $1 6 \longdiv { 5 2 }$ & 124 \\
\hline 934.52 & 7.84 & 925,76 & 754 \\
\hline $44 \quad 44$ & 0.37 & 56,46 & 0,44 \\
\hline 134,76 & 1,55 & 2305 & 1,57 \\
\hline 246,29 & 2.05 & 358,65 & 2,17 \\
\hline 14915,82 & 100 & $12.945,60$ & 100 \\
\hline
\end{tabular}

Geivor 
L L E U N

Funders

Aremen

Alvenere solurd

Bunder

Beretroren en retributies

Yerpebebner

Alienere endntstratse

Pryees natrimonium

Alcenene densten

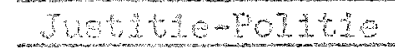

Buscotoen

Venreer-Hesen-16eeryooen

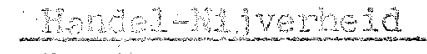

I-nobour

Rleuter-an 1 eser onderwis

Wholekb. Prom. rechn. onderm.

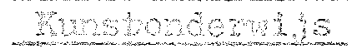

Becer ondertinis

Vol kentwhineling en kinst

Enediengt

eosine voorgore en onderstand

Soga 2010

Gezondictosegrs

Hrifere.poedrn en water

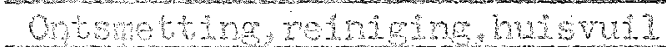

Hesters

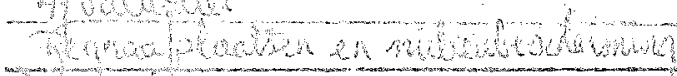

Sulvedenten stedebow

Alceneen toteal

Alecmosa totear

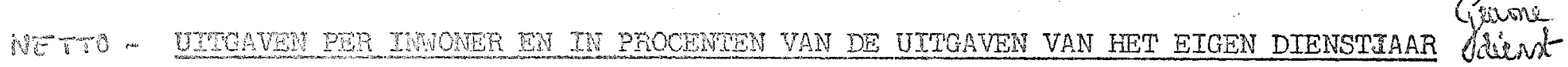

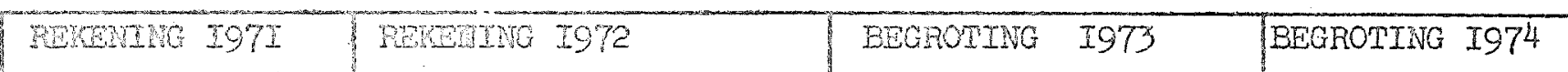

\begin{tabular}{|c|c|c|c|c|c|c|c|}
\hline & & & & & & & \\
\hline Bes I. & In $\%$ & Ber I. & In $\%$ & per I. & $\operatorname{In} \%$ & per $I_{0}$ & In $g^{\prime}$ \\
\hline 200,00 & 2.90 & 186.86 & 35 & $.98,49$ & 2.08 & 177.17 & 1.85 \\
\hline 132,94 & 1,93 & 13901 & 4.84 & 149,42 & 163 & 135,59 & 1,42 \\
\hline- & - & $\ldots$ & $-\infty$ & $-\infty$ & $-\infty$ & - & - \\
\hline$=$ & $-\ldots$ & $-\infty$ & - & - & - & $=$ & - \\
\hline 443 & 02 & -40 & $=0.6$ & 124 & 0.21 & 8,23 & 0,09 \\
\hline 112518 & 46.3 & $4.26,66$ & 17,27 & 450578 & 4.33 & 1729.55 & 18,10 \\
\hline 43.34 & 4 & 7.62 & 89 & 93.82 & 1.00 & 161,80 & 1.69 \\
\hline 89,22 & 1.30 & 92.23 & 1.26 & 196,22 & 1,34 & 2.11 .96 & 2,22 \\
\hline $4.21,32$ & 26,3 & 12336 & 16,81 & 4422,37 & 16.38 & h.607, & 16.81 \\
\hline 3626 & 49 & 64065 & 6,02 & $536+2$ & 6,41 & 62732 & 6,5 \\
\hline 4.913 .3 & 13.43 & 1.4208 & $2 b, n$ & $A 54040$ & $\Delta 8,19$ & 1.63396 & 17.09 \\
\hline-50142 & -1.35 & -5362 & -39 & $-660,42$ & -7.60 & $-732,25$ & $=-7,66$ \\
\hline$=32$ & $=9.6$ & -19.69 & -0.65 & -4.46 & $-0,05$ & 4.79 & 0,05 \\
\hline 16116 & 242 & 43,41 & 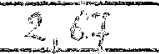 & 233,30 & 275 & 2.23 & 0,03 \\
\hline 38.26 & 459 & 306 & 0.64 & 0,0 & 0.00 & nes & - \\
\hline 8321 & 1.24 & 406,76 & 1,39 & 242.70 & 249 & 5184,26 & 1,98 \\
\hline$=$ & - & $-\infty$ & - mes & - & 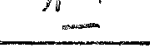 & - & - \\
\hline $6.9,61$ & 1332 & $A D 354$ & An o & $1.342,63$ & 15,36 & 1.638 .62 & 13,14 \\
\hline 38 & 0.48 & 35.11 & 0.4 & 32.05 & 0,37 & 42,19 & 0.44 \\
\hline 8196 & 14.9 & 76,30 & $.10,80$ & 653.54 & 7.53 & 703.52 & 7,36 \\
\hline 2232 & 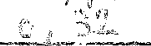 & $26>4$ & 0.3 & 54,45 & $d .68$ & 52,96 & 0,55 \\
\hline 0.83 & 0.00 & 0,1 & 0.0 & 0,32 & 0.00 & 0,32 & 0,00 \\
\hline 108.82 & 145 & 4532 & 0,66 & 7524 & 0,87 & 133,12 & 1,39 \\
\hline $5 \pi 20$ & 8.38 & 60.4 & 8,24 & 405,83 & 928 & 895,37 & 9,37 \\
\hline 1815 & 0,14 & $16,6^{1}$ & 0.16 & 44,44 & 0,37 & $5646^{\circ}$ & 0,44 \\
\hline 43.1 & 1.2 & $45 \cdot 12$ & 148 & 184,76 & 1.55 & 203,05 & 1.57 \\
\hline 289 & 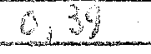 & 62.94 & 0.85 & 452,98 & $1,-6$ & 164,63 & 1,22 \\
\hline 6.883 .85 & .100 & $7.324,29$ & 100 & $8.687 .0 \%$ & 100 & $9.558,63$ & 100 \\
\hline & & & & & & & \\
\hline
\end{tabular}




\begin{tabular}{|c|c|c|c|c|c|c|c|c|c|c|}
\hline \multirow[t]{2}{*}{ EURCWLS } & \multicolumn{2}{|l|}{ DERGONEEI } & \multicolumn{2}{|c|}{ WERCDGSTOSDEN } & \multicolumn{2}{|c|}{ OVERDRACHTEN } & \multicolumn{2}{|l|}{ SCEULD } & \multicolumn{2}{|c|}{$\begin{array}{c}\text { INTERNE } \\
\text { VERRICHTINGEN }\end{array}$} \\
\hline & Pers 1 & $\operatorname{In} \%$ & Per I. & $x_{3} \%$ & PexI. & $\operatorname{In} \%$ & Per $I$ & $\operatorname{In} \%$ & Per I. & In $\%$ \\
\hline 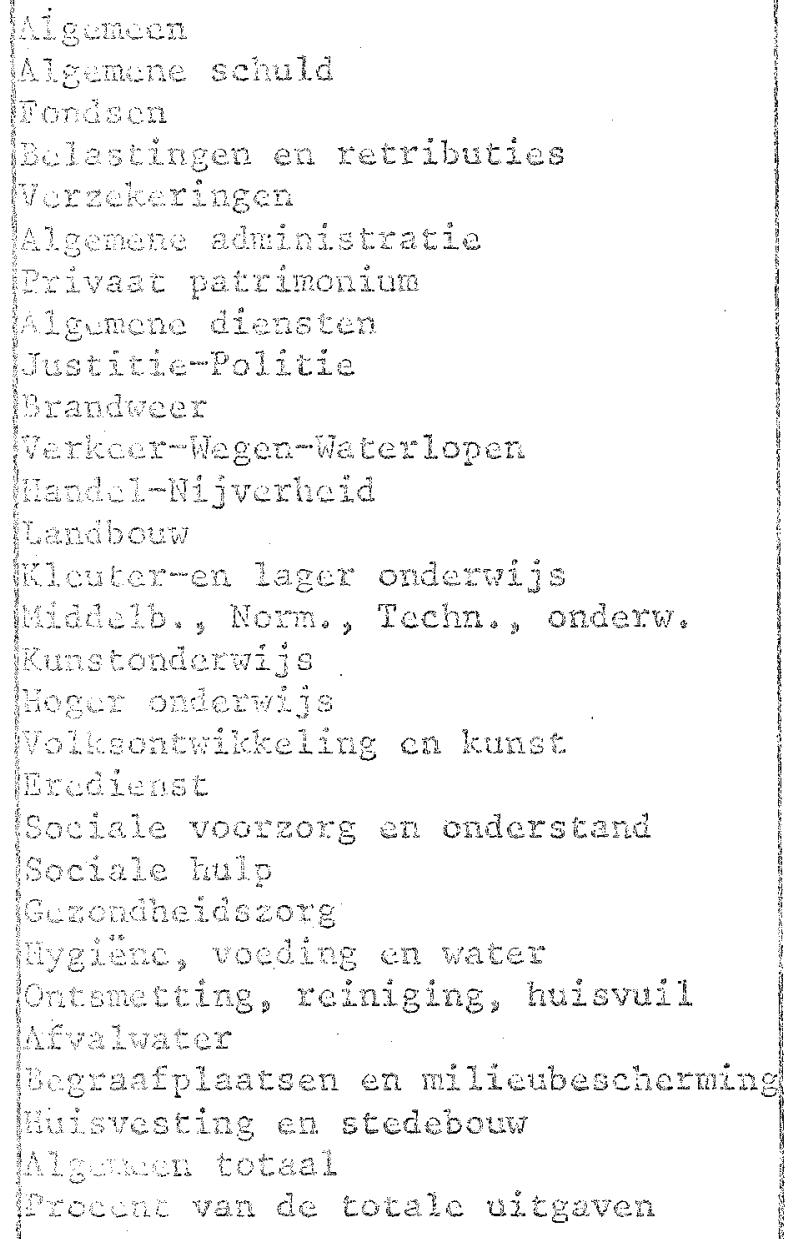 & $\begin{array}{r}13,20 \\
1.202,49 \\
158,30 \\
118,99 \\
1.378,72 \\
676,01 \\
766,91 \\
10,11 \\
371,17 \\
378,23 \\
1.021,24\end{array}$ & $\begin{array}{r}0,19 \\
12,45 \\
2,26 \\
1,30 \\
19,68 \\
9,65 \\
10,95 \\
0,14 \\
5,30 \\
5,40 \\
14,58\end{array}$ & $\begin{array}{r}25,90 \\
140,75 \\
19,34 \\
68,72 \\
49,09 \\
53,20 \\
126,40 \\
14,25 \\
5,47 \\
88,47 \\
37,00 \\
375,74 \\
8,84 \\
1,18 \\
17,34 \\
3,92 \\
234,86 \\
15,63 \\
13,35 \\
1,13 \\
1.290,80\end{array}$ & $\begin{array}{c}2,01 \\
10,00 \\
1,50 \\
5,33 \\
3,00 \\
4,11 \\
9,79 \\
1,10 \\
0,42 \\
6,85 \\
2,87 \\
29,11 \\
0,69 \\
0,09 \\
1,34 \\
0,30 \\
10,20 \\
0,44 \\
1,03 \\
0,09 \\
100 \\
10,83\end{array}$ & $\begin{array}{r}41,34 \\
4,10 \\
652,66 \\
6,02 \\
0,32\end{array}$ & $\begin{array}{l}0,05 \\
0,48 \\
0,02 \\
0,39\end{array}$ & $\begin{array}{r}68,97 \\
26,29 \\
47,13 \\
31,08 \\
55,12 \\
1.361,94 \\
7,63 \\
13,49 \\
1,95 \\
73,85 \\
\\
178,89 \\
22,99 \\
88,35 \\
45,27 \\
106,17 \\
61,73 \\
35,60 \\
10,28 \\
212,59 \\
2.799,62\end{array}$ & $\begin{array}{r}2,46 \\
0,94 \\
1,68 \\
1,11 \\
1,97 \\
48,65 \\
0,27 \\
0,48 \\
0,07 \\
2,64 \\
6,39 \\
0,82 \\
3,16 \\
1,62 \\
3,79 \\
2,21 \\
1,27 \\
6,37 \\
7,59 \\
100 \\
23,49\end{array}$ & $\begin{array}{r}48,32 \\
2,41 \\
3,38 \\
5,15 \\
5,63 \\
3,22 \\
0,45 \\
5,63 \\
8,04 \\
13,51 \\
\\
0,16 \\
\\
8,04 \\
3,22 \\
1,93 \\
109,09\end{array}$ & $\begin{array}{c}44,29 \\
2,21 \\
3,10 \\
4,72 \\
5,16 \\
2,95 \\
0,41 \\
5,16 \\
7,37 \\
12,38 \\
\\
0,15 \\
\\
7,38 \\
2,95 \\
1,77 \\
100 \\
0,92\end{array}$ \\
\hline
\end{tabular}




\begin{tabular}{|c|c|c|c|c|c|c|c|c|c|c|}
\hline \multirow[t]{2}{*}{ FUNonIES } & \multicolumn{2}{|l|}{ RERSONELL } & \multicolumn{2}{|c|}{ MetrTNoskOSTEN } & \multicolumn{2}{|c|}{ OVERORACITEN } & \multicolumn{2}{|l|}{ SCHULD } & \multicolumn{2}{|c|}{$\begin{array}{c}\text { INTERNE } \\
\text { VERRICHTINGEN }\end{array}$} \\
\hline & Pur $X$ & $13 \%$ & Pen $I$ & $\operatorname{In} \%$ & $\operatorname{Pex} 1$ & $\operatorname{In} \%$ & PeI I. & In $\%$ & Per I. & $\operatorname{In} \%$ \\
\hline 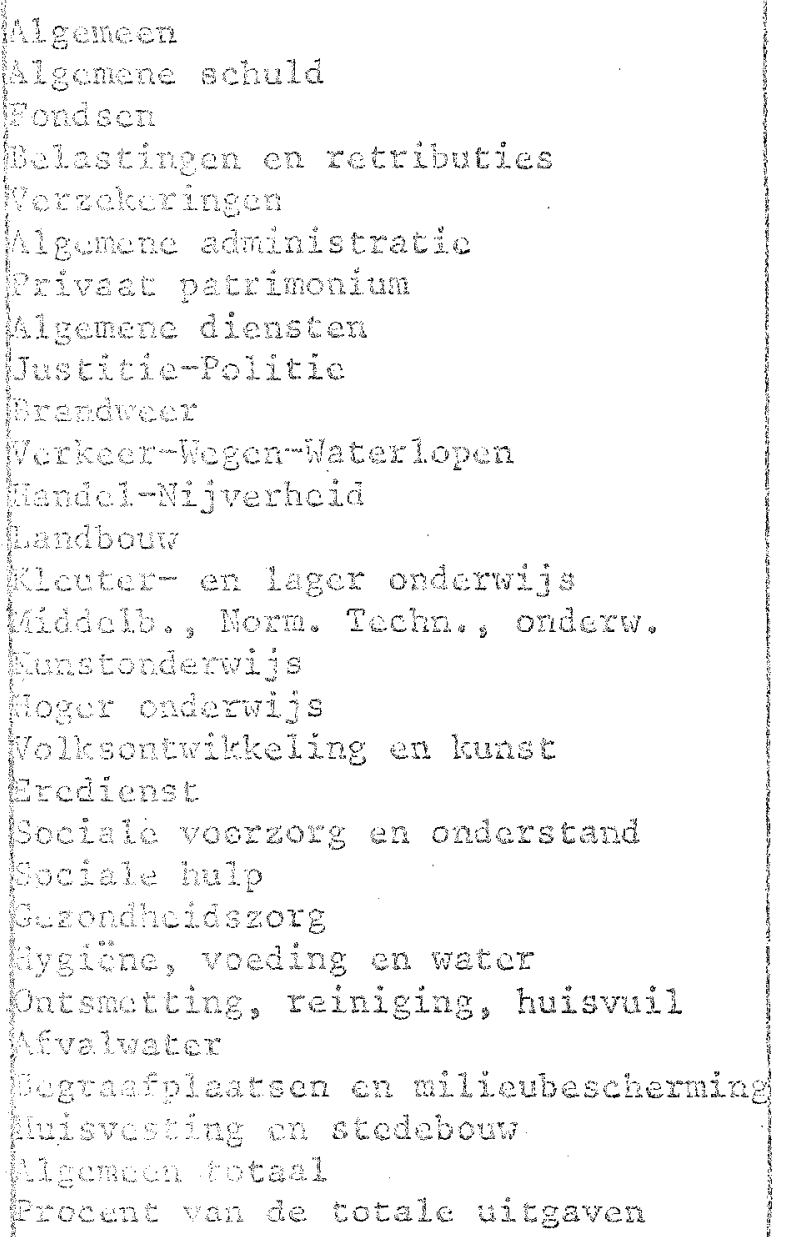 & $\begin{array}{r}15,46 \\
1476,62 \\
229,03 \\
198,39 \\
1,540,90 \\
769,04 \\
851 \\
11,77 \\
62,80 \\
419,20 \\
1.215,53 \\
\\
670,29 \\
176,72 \\
34,28 \\
7.671,03\end{array}$ & $\begin{array}{r}0,20 \\
19,25 \\
2,99 \\
2,59 \\
20,09 \\
10,02 \\
11,09 \\
0,15 \\
0,82 \\
5,46 \\
15,85\end{array}$ & $\begin{array}{r}33,28 \\
205,76 \\
24,28 \\
73,83 \\
64,82 \\
64,37 \\
148,10 \\
18,10 \\
5,14 \\
0,80 \\
60,45 \\
521,83 \\
9,00 \\
0,23 \\
17,27 \\
4,57 \\
238,59 \\
9,97 \\
14,24 \\
1,13 \\
1.516,08\end{array}$ & $\begin{array}{r}2,20 \\
13,57 \\
1,60 \\
4,87 \\
4,28 \\
4,25 \\
9,77 \\
1,19 \\
0,34 \\
0,05 \\
3,90 \\
34,42 \\
0,59 \\
0,01 \\
1,14 \\
0,30 \\
15,74 \\
0,66 \\
0,94 \\
0,07 \\
100 \\
11,71\end{array}$ & $\begin{array}{r}36,01 \\
703,30 \\
9,07 \\
19,68 \\
0,32 \\
\\
3,22 \\
777,12\end{array}$ & $\begin{array}{l}0,04 \\
0,44 \\
0,02 \\
0,21\end{array}$ & $\begin{array}{r} \\
39,29 \\
25,92 \\
56,78 \\
34,34 \\
46,66 \\
1.311,20 \\
12,15 \\
11,45 \\
1,61 \\
19,58 \\
239,16 \\
28,02 \\
24,53 \\
81,70 \\
162,96 \\
58,84 \\
43,28 \\
10,16 \\
320,03 \\
2.872,01\end{array}$ & $\begin{array}{l}1,37 \\
0,90 \\
1,98 \\
1,20 \\
1,62 \\
45,65 \\
0,42 \\
0,40 \\
0,06 \\
0,68 \\
8,33 \\
0,98 \\
0,85 \\
2,85 \\
5,67 \\
2,05 \\
1,51 \\
0,35 \\
11,14 \\
100 \\
22,19\end{array}$ & $\begin{array}{r}6,43 \\
16,56 \\
0,16 \\
\\
8,04 \\
3,22 \\
1,93\end{array}$ & $\begin{array}{r}44,18 \\
2,19 \\
3,09 \\
7,35 \\
5,15 \\
4,41 \\
0,41\end{array}$ \\
\hline
\end{tabular}




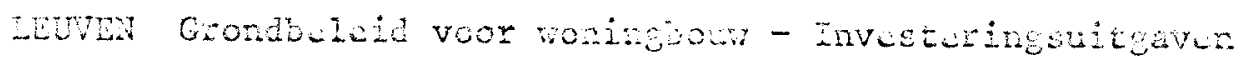

\begin{tabular}{|c|c|c|c|c|c|}
\hline \multirow{2}{*}{ Purioden } & \multicolumn{3}{|c|}{ Investeringur to dragen door } & \multirow{2}{*}{ Totaal } & \multirow{2}{*}{$\begin{array}{l}\text { Procent van deze } \\
\text { investuringen in } \\
\text { het totaal van de } \\
\text { investeringen }\end{array}$} \\
\hline & Guncunte & Staat & Duxdun & & \\
\hline $1950-1864$ & - & - & - & - & - \\
\hline $2065-1570$ & 300.000 & - & - & 300.000 & 0,14 \\
\hline \multirow[t]{4}{*}{$1971-1973$} & 1.534 .000 & - & - & 1.534 .000 & \\
\hline & 22.000 .000 & - & - & 22.000 .000 & \\
\hline & 3.625 .000 & - & - & 3.625 .000 & \\
\hline & - & - & 30.207 .000 & 38.207 .000 & \\
\hline Total & 27.159 .000 & - & 36.207 .000 & 65.368 .000 & 21,23 \\
\hline 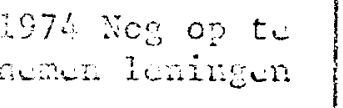 & 5.000 .000 & - & 12.000 .000 & 17.000 .000 & 10,03 \\
\hline Eotaal $1971-2974$ & 32.159 .000 & - & 50.207 .000 & 70.366 .000 & 17,50 \\
\hline Igunun totáa & 32.459 .000 & - & 50.207 .000 & 70.666 .000 & 9,35 \\
\hline
\end{tabular}

aankoop van grond Dicstscstraat

aankoop eigendom ter vorwuzenlijking van St. Gertrudiswijk

aankoop grond

Ticnsustraat

aankoop grond voor urbanisatieverkave-

lingen

aankoop van grond door de Regie

aankoop van grond 


\begin{tabular}{|c|c|c|c|c|}
\hline \multirow{2}{*}{ Puriotun } & \multicolumn{2}{|c|}{ Tnveturingua te dragen dror } & \multirow{2}{*}{ Totaal } & \multirow{2}{*}{$\begin{array}{l}\text { Proccrit van do } \\
\text { investeringen voor } \\
\text { milicu in het } \\
\text { toteal van do } \\
\text { investuringun }\end{array}$} \\
\hline & Guntater & Scoat & & \\
\hline $1050-106 \%$ & - & - & - & - \\
\hline $1965 \times 1970$ & 1.700 .000 & - & 1.700 .000 & 0,01 \\
\hline $2071-2973$ & 1.003 .000 & - & 1.803 .000 & 0,61 \\
\hline $\begin{array}{l}974 \text { nog on }= \\
\text { won luningun }\end{array}$ & 1.250 .000 & - & 1.250 .000 & 1,33 \\
\hline $1971-2974$ & 3.143 .000 & - & 3.143 .000 & 0,78 \\
\hline $\begin{array}{l}7 \text { ounana } \\
\text { totanl }\end{array}$ & 4.843 .000 & - & 4.343 .000 & 0,68 \\
\hline
\end{tabular}

worken aan de kruidtuin werkon kruidtuin, stadspark, enz.

herstellingswerken aan de kruidtuin en aankoop maturiaal 


\begin{tabular}{|c|c|c|c|c|c|c|c|c|}
\hline & \multicolumn{8}{|c|}{ Wifaven in abolitis cy en } \\
\hline & \multirow{2}{*}{\multicolumn{4}{|c|}{ Rekeninger }} & \multicolumn{4}{|c|}{ Begrotingen } \\
\hline & & & & & \multicolumn{2}{|c|}{1973} & \multicolumn{2}{|c|}{1974} \\
\hline PERSONEEL & \multicolumn{2}{|c|}{9.497 .631} & \multicolumn{2}{|c|}{10.750 .621} & \multicolumn{2}{|c|}{12.660 .942} & \multicolumn{2}{|c|}{14.124 .000} \\
\hline WERKINGSKOSTEN & \multicolumn{2}{|c|}{831.571} & \multicolumn{2}{|c|}{854.868} & \multicolumn{2}{|c|}{886.000} & \multicolumn{2}{|c|}{1.206 .000} \\
\hline OUERDRBCHTEN & \multicolumn{2}{|c|}{-} & \multicolumn{2}{|c|}{-} & \multicolumn{2}{|c|}{-} & \multicolumn{2}{|l|}{ - } \\
\hline SCHULD & \multicolumn{2}{|c|}{255.226} & \multicolumn{2}{|c|}{316.320} & \multicolumn{2}{|c|}{334.820} & \multicolumn{2}{|c|}{460.000} \\
\hline WTERUE VERRACHT. & \multicolumn{2}{|c|}{55.438} & \multicolumn{2}{|c|}{61.662} & \multicolumn{2}{|c|}{65.000} & \multicolumn{2}{|c|}{65.000} \\
\hline TOTARL BRUTO UITEAVEN & \multicolumn{2}{|c|}{10.639 .615} & \multicolumn{2}{|c|}{11.983 .471} & \multicolumn{2}{|c|}{ 14.006.762 } & \multicolumn{2}{|c|}{15.855 .000} \\
\hline TOTAML NETTO UITGAVEM & \multicolumn{2}{|c|}{10.639 .615} & \multicolumn{2}{|c|}{11.983 .47} & \multicolumn{2}{|c|}{14.006 .762} & \multicolumn{2}{|c|}{15.855 .000} \\
\hline \multirow[b]{2}{*}{ TOTAAL: } & \multicolumn{8}{|c|}{ 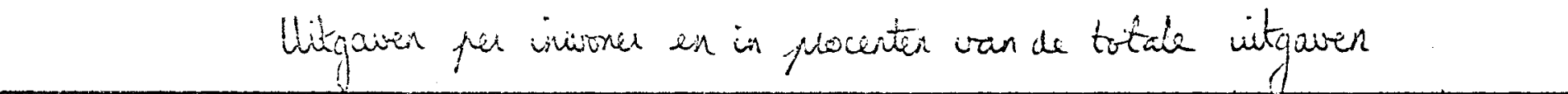 } \\
\hline & pul vis. & in 2 & pil livir. & is $\%$ & pet vivi. & $\therefore 2$ & per inw. & $\ddot{2} 2$ \\
\hline Juin uigavin & 340,21 & 3,62 & 385,53 & 3,80 & 450,62 & 3.78 & 509,81 & 3,94 \\
\hline Weito witgden & 340,21 & 4,94 & $3: 5.53$ & 5,27 & 450,62 & 5,19 & 509,81 & 5,33 \\
\hline
\end{tabular}




\begin{tabular}{|c|c|c|c|c|}
\hline \multirow{2}{*}{ EATHOA } & \multicolumn{2}{|c|}{ Tavesturingun to drasun doon } & \multirow{2}{*}{ Totaal } & \multirow{2}{*}{$\begin{array}{l}\text { Poocurt van de } \\
\text { iavestcringun } \\
\text { voor sport in } \\
\text { hot total van } \\
\text { de investeringen }\end{array}$} \\
\hline & Cumuto & Stazt & & \\
\hline $1950-1064$ & $\begin{array}{l}1.000 .000 \\
2.260 .000\end{array}$ & - & $\begin{array}{l}1.000 .000 \\
1.260 .000\end{array}$ & \\
\hline Totan & 2.260 .000 & - & 2.260 .000 & 2,16 \\
\hline $1965-1970$ & 3.420 .000 & 4.410 .000 & 7.828 .000 & 3,72 \\
\hline \multirow[t]{4}{*}{$1570-1973$} & 2.734 .000 & - & 2.734 .000 & \\
\hline & 6.606 .000 & - & 6.605 .000 & \\
\hline & 411.000 & - & 411.000 & \\
\hline & 314.000 & - & 314.000 & \\
\hline Totaal & 10.345 .000 & - & 10.346 .000 & 3,36 \\
\hline $\begin{array}{l}\text { L74 nog op to } \\
\text { whon intrgen }\end{array}$ & $\begin{array}{r}6.500 .000 \\
700.000\end{array}$ & - & $\begin{array}{r}6.500 .000 \\
700.000\end{array}$ & \\
\hline Hotal & 7.200 .000 & - & 7.200 .000 & 7,64 \\
\hline Potoal 1971-1974 & 17.546 .000 & - & 17.546 .000 & 4,36 \\
\hline Demuch toraas & 23.224 .000 & 4.410 .000 & 27.634 .000 & 3,85 \\
\hline
\end{tabular}

uitrusting sportcentrum uitrusting zwumbassin

verwezenlijking van de $3^{\circ}$ faze van het sportcentrum

verwozenlijking van de $3^{\circ}$ faze + uitrusting van lect sportcuntrum

ombouwen van de gewezen rijschool tot sportzaal vergrotun rolschaatspiste op het spel- en sportterruin "DC Bruul".

uitrusting zwembassin

uitrusting sportcentrum werken zwembassin 


\section{SPORTBELEID}

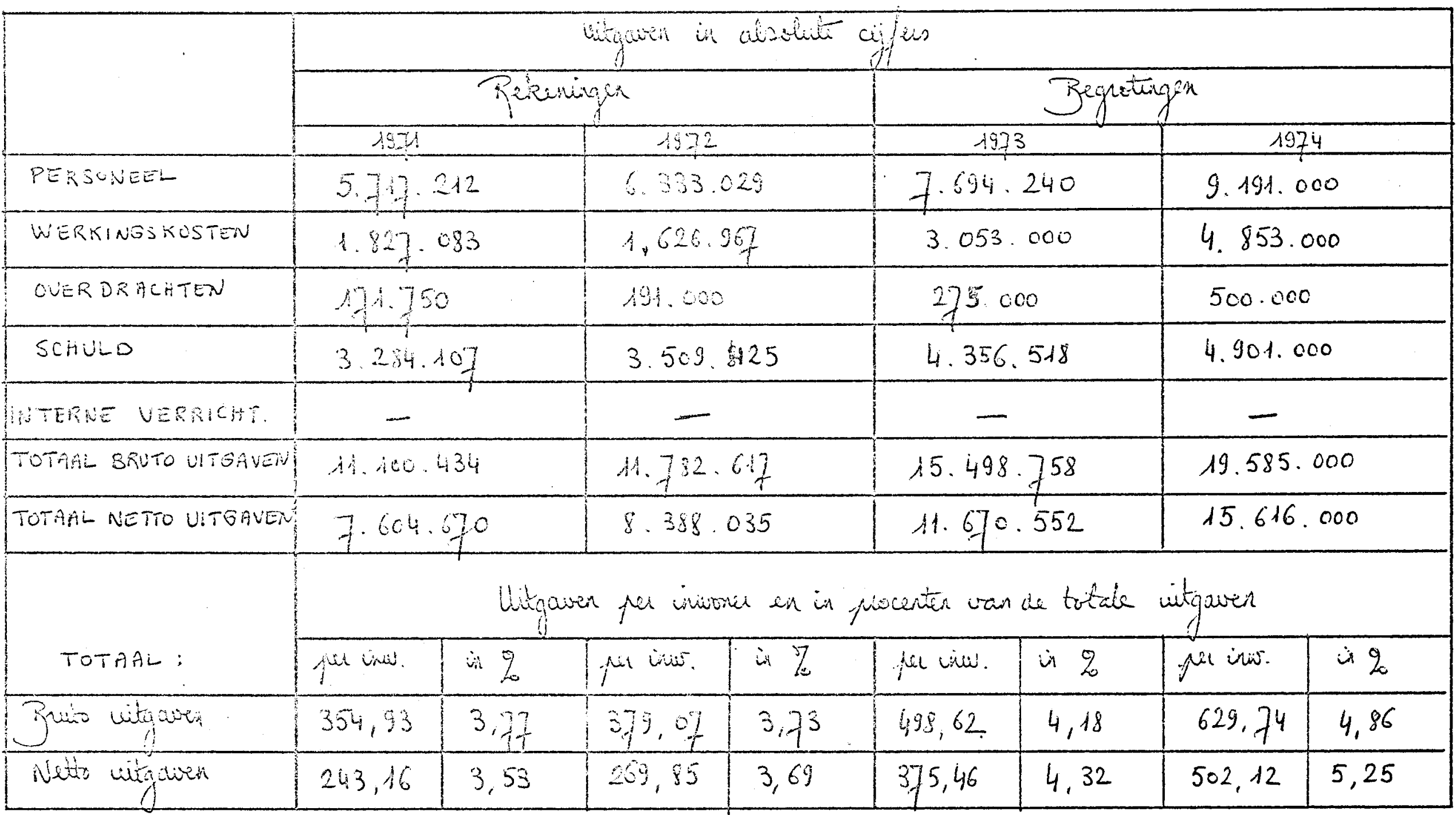




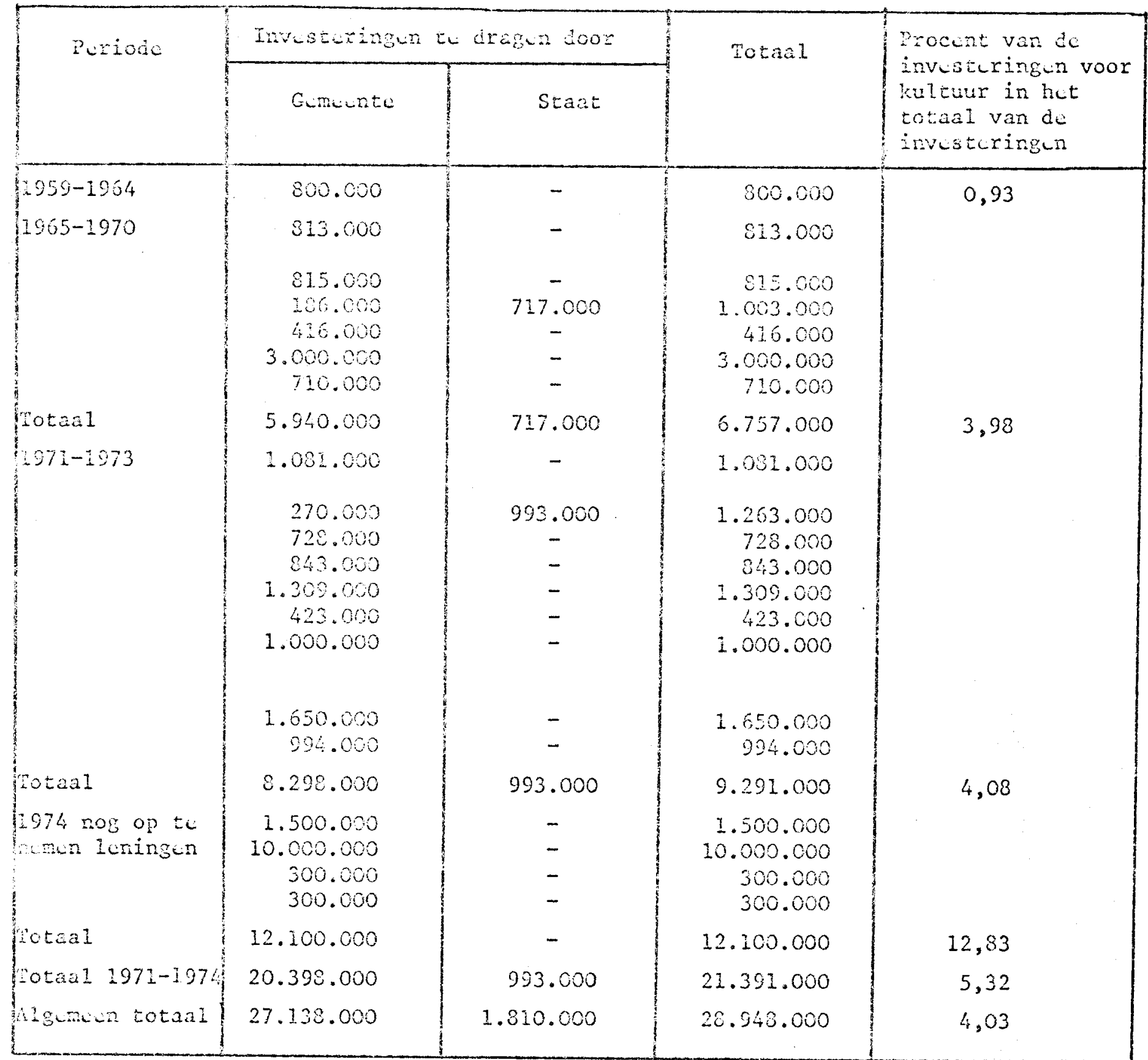

werken St. Pieters kerk

aanpassingswerken aan hot museum Vanderkelen-Mertens

uitrusting stadsschouwburg wurken O.L.Vrouw tun Predikheren werkon St.Gertrudis kurk rustauratiewerken aan St.Kwintenskerk herstel St. Picterskork

aanpassingswerken aan hut muscum Vanderkelon-Mortens

workun St.Pictorskork

restauratie "Oude Kartuizerij"

rostauratie St.Kwintenskerk

rustauratie St.Jacobskerk

uitbreidingswerken stadsbibliotheck

aankoop kloostcrpand Gasthuiszusters met het oog op de vestiging van een culturcel contrum verbouwing van de stadshuiskelders overige investcringen.

uitbreiding stedelijke bibliotheek stedelijke stichting voor monumentenzorg restauratie "Oude Kartuizerij" restauratic gebouw Mechelsestraat 


\begin{tabular}{|c|c|c|c|c|c|c|c|c|}
\hline & \multicolumn{8}{|c|}{ suguter in absoliti aj/er } \\
\hline & \multicolumn{4}{|c|}{ Premingar } & \multicolumn{4}{|c|}{ Begrotingin } \\
\hline & \multicolumn{2}{|l|}{1971} & \multicolumn{2}{|c|}{1972} & \multicolumn{2}{|c|}{1973} & \multicolumn{2}{|c|}{1974} \\
\hline PERSONEEL & \multicolumn{2}{|c|}{8.804 .603} & \multicolumn{2}{|c|}{$9.973,037$} & \multicolumn{2}{|c|}{11.357 .876} & \multicolumn{2}{|c|}{14.488 .000} \\
\hline WERKANGSKOSTEN & \multicolumn{2}{|c|}{5.256 .412} & \multicolumn{2}{|c|}{$6.225,203$} & \multicolumn{2}{|c|}{ ]. 490,000} & \multicolumn{2}{|c|}{9.770 .000} \\
\hline OUER DRHEHTEN & \multicolumn{2}{|c|}{$23 \% .000$} & \multicolumn{2}{|c|}{$312+190$} & \multicolumn{2}{|c|}{605.000} & \multicolumn{2}{|c|}{505.000} \\
\hline SCTULO & \multicolumn{2}{|c|}{267.918} & \multicolumn{2}{|c|}{349.641} & \multicolumn{2}{|c|}{781.000} & \multicolumn{2}{|c|}{1.955 .000} \\
\hline NNTERBE VERRICHT. & \multicolumn{2}{|c|}{$18+251$} & \multicolumn{2}{|c|}{238.663} & \multicolumn{2}{|c|}{235.000} & \multicolumn{2}{|c|}{260.000} \\
\hline TOTFRL BRUTO UITGAVAU & \multicolumn{2}{|c|}{$34,744,384$} & \multicolumn{2}{|c|}{$1] .093 .044$} & \multicolumn{2}{|c|}{20.499 .852} & \multicolumn{2}{|c|}{26.978 .000} \\
\hline TOTAMA NETTO UITEAVET & \multicolumn{2}{|c|}{10.196 .027} & \multicolumn{2}{|c|}{12.393 .336} & \multicolumn{2}{|c|}{15.124 .852} & \multicolumn{2}{|c|}{20.158 .000} \\
\hline \multirow[b]{2}{*}{ TOTABL: } & \multicolumn{8}{|c|}{ Wirgaver per wivioned en in procenter van de totak witgaren } \\
\hline & pill vinel. & in 9 & pat inis. & in $\%$ & ful vili. & is 2 & pll init. & i 2 \\
\hline Puto ingan & $4,1,45$ & 5,01 & 550,4 & 5,42 & 659,52 & 5,53 & $8,67,46$ & 6.70 \\
\hline Wello witgdich & 326,02 & 4.73 & 358.72 & 5,45 & 486,60 & 5,60 & 648,17 & 6,78 \\
\hline
\end{tabular}




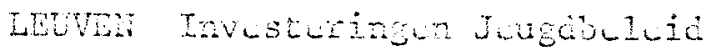

\begin{tabular}{|c|c|c|c|c|}
\hline \multirow{2}{*}{ Burodun } & \multicolumn{2}{|c|}{ Investoringun th dragur coor } & \multirow{2}{*}{ Totaal } & \multirow{2}{*}{$\begin{array}{l}\text { Procent van de } \\
\text { investuringun voor } \\
\text { jusgd in hut } \\
\text { totaal van de } \\
\text { investeringun }\end{array}$} \\
\hline & Catanteo & seact & & \\
\hline $0959-1064$ & - & - & - & - \\
\hline $1965-1970$ & - & - & - & - \\
\hline $1971-2073$ & - & - & - & - \\
\hline $\begin{array}{l}1974 \text { nog on to } \\
\text { Lemun } \\
\text { Lutroun }\end{array}$ & 3.000 .000 & - & 1.000 .000 & 1,06 \\
\hline $1971-1974$ & 1.000 .000 & - & 1.000 .000 & 0,25 \\
\hline $\begin{array}{l}18 \text { coun } \\
\text { totadi }\end{array}$ & 1.000 .000 & - & 1.000 .000 & 0,14 \\
\hline
\end{tabular}

aanleg kwartierspeclpleinen 


\section{JEUGDBELEID}

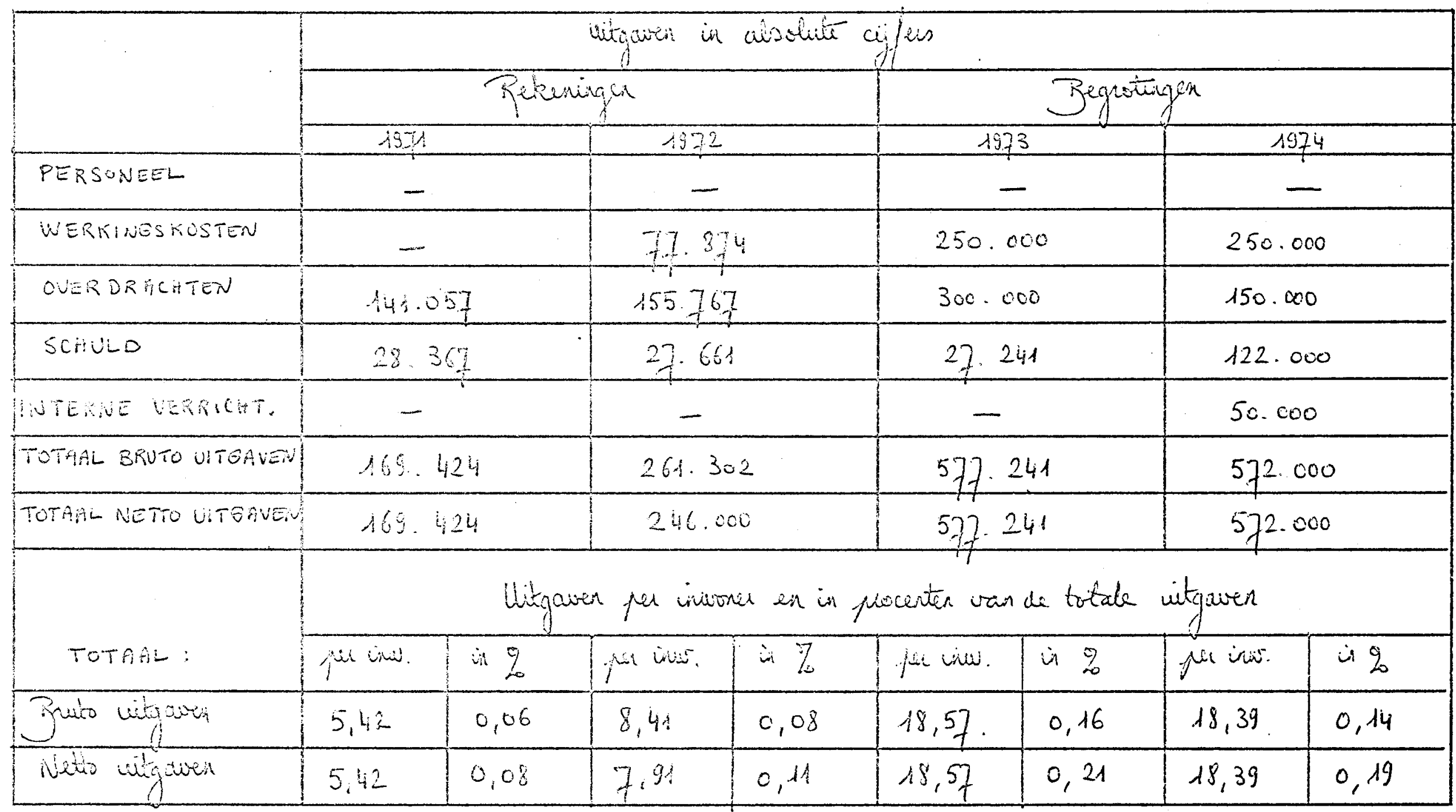




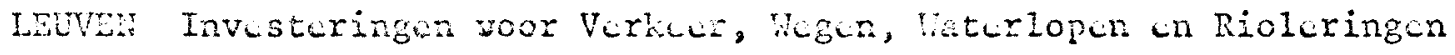

\begin{tabular}{|c|c|c|c|c|c|}
\hline \multirow{2}{*}{ Foriocen } & \multicolumn{3}{|c|}{ Investuringen te dragun door } & \multirow{2}{*}{ Total } & \multirow{2}{*}{$\begin{array}{l}\text { \% van deze } \\
\text { investeringen in } \\
\text { het totaal van } \\
\text { de investeringen }\end{array}$} \\
\hline & Genocntc & Staat & Derden & & \\
\hline $1059-1954$ & 71.222 .000 & 2.022 .000 & 3.500 .000 & 76.744 .000 & 73,34 \\
\hline $11965-1970$ & 133.357 .490 & 6.366 .000 & 10.000 .000 & 149.723 .490 & 71,08 \\
\hline $1971-1973$ & 144.643 .000 & 106.165 .000 & - & 160.813 .000 & 52,24 \\
\hline $\begin{array}{l}\text { Oth nog op } \\
\text { d numur } \\
\text { andingun }\end{array}$ & 40.800 .000 & 5.200 .000 & - & 46.000 .000 & 48,78 \\
\hline potala $1072-1574$ & $135.448,000$ & 21.365 .000 & - & 206.813 .000 & 51,43 \\
\hline Mromosn tocael & 390.027 .400 & 29.753 .000 & 13.500 .000 & 433.280 .490 & 60,39 \\
\hline
\end{tabular}




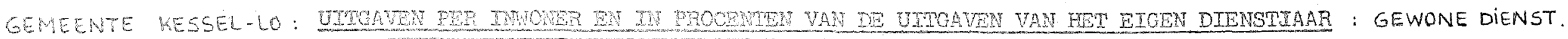

FOnCTISS

\begin{tabular}{|c|c|c|}
\hline \multicolumn{3}{|c|}{ Whenesy } \\
\hline \multicolumn{2}{|c|}{ WOWMV 1972} & MEDMO I \\
\hline Per I sua & $\operatorname{Tn} 8$ & Per Inw. \\
\hline$\pm \quad 18$ & 0.06 & 0.44 \\
\hline 3137 & 0,17 & 21.82 \\
\hline-3 & $-\infty$ & - \\
\hline 0.12 & 0,0 & 0,46 \\
\hline II & 0.41 & 15,42 \\
\hline 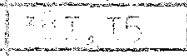 & 2486 & 477,65 \\
\hline 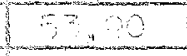 & 2.5 & 64.03 \\
\hline & $\ldots$ & - \\
\hline 271,6 & 20.67 & 320,56 \\
\hline 112.73 & 1.67 & 19,20 \\
\hline 046.39 & 25,24 & 754,34 \\
\hline 50,34 & 2.97 & 27,79 \\
\hline & $-\infty$ & - \\
\hline $17 O_{2} 4 I$ & 6.97 & 50,8 \\
\hline- & - & - \\
\hline 13,10 & 0.53 & 3,34 \\
\hline- & $+\infty$ & - \\
\hline 20,33 & $9=3$ & 270,71 \\
\hline 21,9 & 0,86 & 37.10 \\
\hline 26306 & 1045 & 240,13 \\
\hline 16,7 & 0,73 & 3017 \\
\hline 522 & 2.15 & 63,4 \\
\hline $57 \cdot 5$ & 2.24 & $.6 I \quad 7$ \\
\hline 110,04 & 584 & 23329 \\
\hline 92.65 & I.66 & 45.24 \\
\hline 39,31 & $T .19$ & $3 ., 03$ \\
\hline 13,00 & 65 & $4 I .90$ \\
\hline $255 \%, 24$ & 100,00 & 2770.56 \\
\hline & & \\
\hline
\end{tabular}
BEgROTINGSUITGAVEN.

\begin{tabular}{|c|c|c|c|c|}
\hline WTOSON. & & BEGROTIN & LITGAVEN & \\
\hline 972 & BEGROIING & 1973 & BEGROTING & \\
\hline $\ln g$ & Per Inw. & In $\%$ & Per Inw. & In $\%$ \\
\hline 0,0 & 0,84 & 0,02 & 0,84 & 0,02 \\
\hline 0.43 & $\pi, B 2$ & 0,29 & $I I, 70$ & 0,26 \\
\hline- & - & - & - & - \\
\hline 0,02 & 0.42 & $0.0 I$ & 0.84 & 0,02 \\
\hline 0.56 & $I 7.86$ & 0,45 & $\mathrm{IO}, 6 \mathrm{I}$ & $0,4 I$ \\
\hline 15.07 & 521.91 & $I 3,05$ & 631,57 & 13,84 \\
\hline 2,31 & 85,26 & 2,13 & 117.57 & 2,58 \\
\hline- & - & - & - & - \\
\hline II. 92 & 387.33 & 9.68 & 474,44 & 10,40 \\
\hline 1.52 & 47,50 & $I . I 9$ & 54.62 & $I, 20$ \\
\hline 27.25 & 1081,63 & $27.0 \%$ & IIOO,IO & 24,11 \\
\hline 1,00 & 146,41 & 3,60 & 143,48 & 3.15 \\
\hline 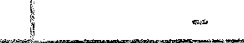 & - & - & - & - \\
\hline 2.04 & $5 I, 24$ & $I, 30$ & 53.27 & $I . I 7$ \\
\hline- & - & - & - & - \\
\hline 0,12 & 2.77 & 0,07 & 4.80 & 0,10 \\
\hline- & - & - & - & - \\
\hline $9: 77$ & 670,41 & 16,70 & 804,93 & 17,64 \\
\hline 1,34 & 34,04 & 0,85 & 7,56 & $I .63$ \\
\hline 8.67 & 332,38 & $8,3 I$ & 337.12 & 7.39 \\
\hline 1,03 & 37,16 & 0.93 & 64.58 & 1.42 \\
\hline 2,30 & 01,91 & 2,03 & 90,31 & 2,15 \\
\hline 2.23 & 62,54 & $I, 56$ & 74.06 & $I, 62$ \\
\hline 8.06 & 220,45 & $5.7 I$ & 265.02 & $5.8 I$ \\
\hline I. 63 & 89,66 & 2.24 & 92,65 & 2,03 \\
\hline$I . I 2$ & 48.23 & $I, 20$ & $5 I, 44$ & $I, I 3$ \\
\hline 1.52 & 59.86 & $I, 50$ & 87.63 & I.92 \\
\hline 100,00 & 4000,43 & 100,00 & 4562,20 & 100,00 \\
\hline & & & & \\
\hline
\end{tabular}




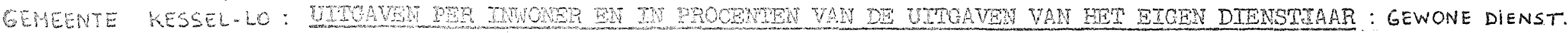

FUNCTISS

\begin{tabular}{|c|c|c|c|}
\hline \multicolumn{4}{|c|}{ WEARELMH } \\
\hline \multicolumn{2}{|c|}{ WBSNMG T971 } & \multicolumn{2}{|c|}{ DESUING I972 } \\
\hline Eer I I w & $\operatorname{In} \%$ & Pen Inw. & $\ln 9$ \\
\hline$-5 \mathrm{~s}, 9$ & $-2,56$ & $-\quad 45.0 T$ & $2.0 I$ \\
\hline 10,92 & 0.54 & 1070 & 0.49 \\
\hline+ & $\infty$ & + & - \\
\hline- & $\ldots$ & - & - \\
\hline $4 \times 9$ & 0.25 & 7,31 & $a-9$ \\
\hline 363.3 & 18.08 & 410,39 & $10 \quad 3$ \\
\hline 5043 & $25 I$ & 60.67 & 37 \\
\hline$=$ & $-m$ & 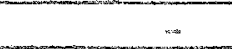 & - \\
\hline $27 t .68$ & 13.52 & 320,56 & 14,73 \\
\hline 42.75 & 213 & 42,22 & 7.89 \\
\hline $56 x .93$ & 37.06 & 669,02 & 29.93 \\
\hline-8405 & -43 & -11008 & -532 \\
\hline-0.38 & $-0,02$ & $-\quad I 53$ & 0.07 \\
\hline 86,07 & 4.28 & 56.65 & 2.53 \\
\hline$+\infty$ & $=$ & - & $-\infty$ \\
\hline 2.60 & 0.13 & $3.3 I$ & 0.75 \\
\hline- & 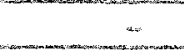 & $x$ & - \\
\hline 392.12 & $8,8 x$ & 225,35 & 10.07 \\
\hline $15 \cdot 20$ & 0.76 & 19.58 & 0.88 \\
\hline 243.67 & $12+14$ & 213.50 & 9.55 \\
\hline 18.7 & 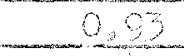 & 28.7 & 2.27 \\
\hline 20,21 & 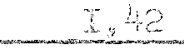 & 30,0 & $I_{0}, 34$ \\
\hline 46.49 & $23 I$ & 7.54 & 0.34 \\
\hline 22159 & 6.03 & 203,52 & 9.10 \\
\hline 39,30 & 196 & 42,25 & $\therefore .89$ \\
\hline 2912 & 24 & 13,18 & 0.69 \\
\hline 2829 & 0.60 & 40,09 & 1.79 \\
\hline $2009,6 I$ & 200.00 & 2235.57 & 100,00 \\
\hline & & & \\
\hline
\end{tabular}

\begin{tabular}{|c|c|c|c|}
\hline \multicolumn{4}{|c|}{ EEGROTINGSUITGAYEN. } \\
\hline \multirow{2}{*}{$\frac{\text { BECRONING }}{\text { en InW. }}$} & \multirow{2}{*}{$\frac{1973}{\operatorname{In} \%}$} & \multicolumn{2}{|c|}{ BEGROTING I974 } \\
\hline & & Per Itw. & In $\%$ \\
\hline$-\quad 39.27$ & $I, 26$ & 28,57 & 0.76 \\
\hline 10.79 & 0.35 & 10,73 & 0.28 \\
\hline$\ldots$ & - & - & - \\
\hline$=$ & $=$ & - & - \\
\hline-33.64 & 0.44 & I0,2I & 0,27 \\
\hline $5, .27$ & $\mathrm{~J} 0.53$ & $625, I 0$ & 15,57 \\
\hline 8,5 & 2.04 & $I I 3,36$ & 3.00 \\
\hline & - & - & - \\
\hline 267,33 & $I 2_{4}+2$ & 474,44 & 12.57 \\
\hline 47.50 & $I .52$ & 54.62 & I. 45 \\
\hline 870.10 & $27.9 \pi$ & 959,60 & 25.43 \\
\hline 62.65 & 2.01 & 38.53 & I. 02 \\
\hline$\pi, 28$ & 0,04 & I.27 & 0,03 \\
\hline 39,37 & $I .26$ & 38,16 & $I, O I$ \\
\hline- & - & - & - \\
\hline 2,69 & 0,09 & 4,71 & 0,13 \\
\hline- & - & - & - \\
\hline 45452 & 14,90 & 583.45 & $I 5,46$ \\
\hline 16,64 & 0.53 & 58,49 & $I .55$ \\
\hline 305,72 & $9.8 I$ & $3 I 0.15$ & 8,22 \\
\hline 37.16 & $1, I 9$ & 64.58 & $I, 7 I$ \\
\hline 48,89 & I.57 & 65,45 & $x, 73$ \\
\hline 247 & 0.08 & 13.83 & 0.37 \\
\hline 207.33 & 6.65 & $248,2 I$ & 6.58 \\
\hline 82,47 & 2.64 & $89, T_{4}$ & 2.36 \\
\hline 30,06 & 0,99 & 34,25 & $0,9 I$ \\
\hline 55.77 & I. 79 & 83.57 & $2.2 I$ \\
\hline $3 I I 7.84$ & $I 00,00$ & 3773,76 & $I 00,00$ \\
\hline
\end{tabular}

Atosengen

Ansemene schnid

Dengses

Belestengen on retrubuter

Wereterangen?

Alemene cominjerente

Pntyeet pectimonim

A2genene densten

Buttele-poldise

Bundiese

Bemberulesen-hateriopen

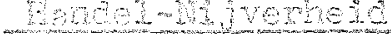

X-nobour

Wenter-en 1 serer ondermis

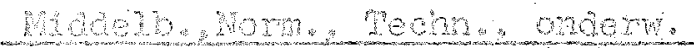

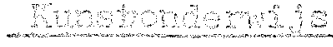

Hoese ondondis

Wo keontundeling en lunet

Bredienst

Boplale voorzore en ondereterd

Bogtate mLa

Genonetosyore

Buglerovedno on water

ontrottine retrinine wustud AFUnWhes

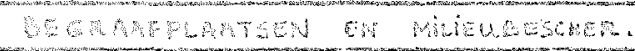

Wulevesetno en stedeboni

Algeneer totel

$2009,6 I$ 
Aresmegr

Aremene sobud

Foreses

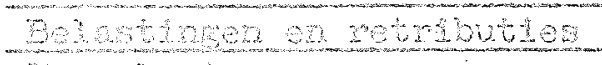

Vepectereneser

10

Bribet petrimontim

Aremene deneten

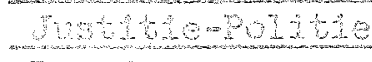

Bundrecro

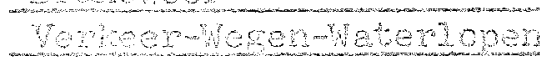

Bende -2 Myerbe 20

I- nobont

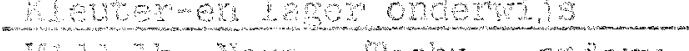

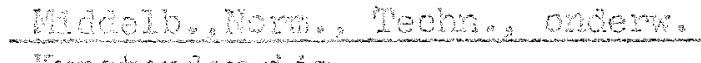
Wunotondervits

Eorer ondertis _ _ _

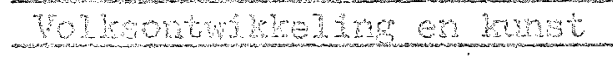

wedtectet

Sectos woyrope en onceretrand

Sotale mes

perendhesoseon

Wetrow voedins en water

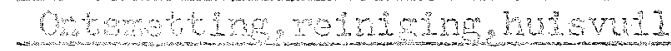
mentwarted

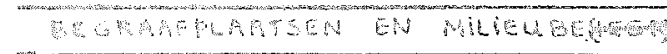
Huterestins en stedeboum

Algomen total

Progent QB B. rotare Uiteaven.

\begin{tabular}{|c|c|c|}
\hline \multicolumn{2}{|c|}{ FEMSONEEL } & WERking \\
\hline Pex now & $\operatorname{In} \%$ & Der thw. \\
\hline & & 0,84 \\
\hline & & \\
\hline & & \\
\hline & & \\
\hline 836 & 0,0 & 5,30 \\
\hline $40 \times 50$ & 869 & 110.45 \\
\hline 34,89 & 5,32 & $-5,31$ \\
\hline- & - & $\sim$ \\
\hline 352,64 & 25,5 & 25.02 \\
\hline- & - & 5,28 \\
\hline 2328 & 46,56 & 433,74 \\
\hline-- & - & 2,74 \\
\hline- & - & - \\
\hline 2,82 & 0,80 & 8,66 \\
\hline- & - & - \\
\hline 4.54 & $\omega_{1}$ & 127 \\
\hline- & - & $\ldots$ \\
\hline 142,3 & 10,13 & 54,23 \\
\hline- & -- & 10,43 \\
\hline- & - & 8,3 \\
\hline - & & 4,1 \\
\hline 56,41 & $4,0.1$ & 13,87 \\
\hline- & $=$ & 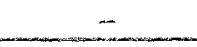 \\
\hline 938 & 6,90 & 34,20 \\
\hline- & - & $-10,85$ \\
\hline 23,05 & -1.64 & 1,39 \\
\hline- & - & 2,09 \\
\hline 1406.76 & 100 & 450,33 \\
\hline 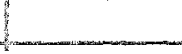 & 35,13 & \\
\hline
\end{tabular}

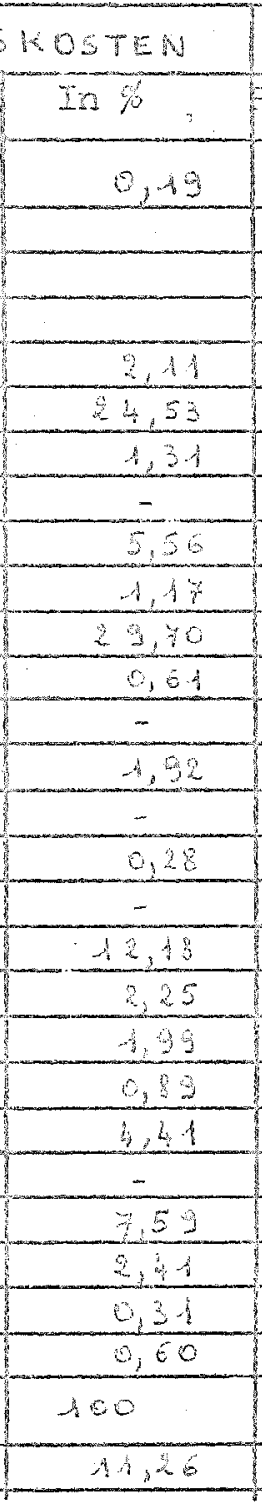

\begin{tabular}{|c|c|}
\hline \multicolumn{2}{|c|}{ OVERDACHTEN } \\
\hline er I row. & $\operatorname{In} \%$ \\
\hline & \\
\hline & \\
\hline 0,42 & 0 \\
\hline & \\
\hline & \\
\hline & \\
\hline & \\
\hline 42,22 & $9, A 4$ \\
\hline 0,08 & 0,02 \\
\hline 2,53 & 0,55 \\
\hline & \\
\hline & \\
\hline & \\
\hline & \\
\hline 59,03 & 12,78 \\
\hline 2,96 & 0,64 \\
\hline 306,41 & 65,27 \\
\hline 33,45 & 9.18 \\
\hline 2,87 & 0,62 \\
\hline 0,21 & 0,05 \\
\hline- & - \\
\hline 4,23 & 0,28 \\
\hline 15,62 & 3,38 \\
\hline 461,77 & 100 \\
\hline 465 & $-11,54$ \\
\hline
\end{tabular}

\begin{tabular}{|c|c|}
\hline \multicolumn{2}{|c|}{ SCHULD. } \\
\hline Per Inw. & $\operatorname{In} \%$ \\
\hline 14,82 & 0,70 \\
\hline & \\
\hline & \\
\hline 3,96 & 0,24 \\
\hline 4,46 & 0,27 \\
\hline- & - \\
\hline 2,67 & 0,16 \\
\hline- & - \\
\hline 714,911 & 42,51 \\
\hline 141,13 & 8,39 \\
\hline 40,46 & $2,4-1$ \\
\hline & \\
\hline 413,99 & 24,62 \\
\hline 20,35 & 1,25 \\
\hline 22,02 & 1,31 \\
\hline- & - \\
\hline 2,76 & 0,16 \\
\hline 62,64 & 3,72 \\
\hline 96,92 & 5,46 \\
\hline 78,81 & 4.69 \\
\hline 22,52 & 1,34 \\
\hline 41,55 & 2,47 \\
\hline 1681,57 & 100 \\
\hline & 42,03 \\
\hline
\end{tabular}


GEMEENTE KESSEL-LO

Begnoting $137 \%$

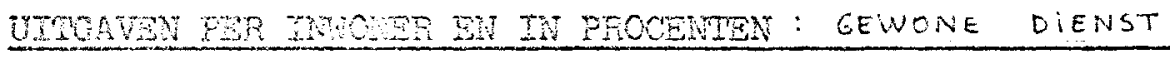

\begin{tabular}{|c|c|c|c|c|c|c|c|c|}
\hline \multirow{2}{*}{ Futoms } & \multicolumn{2}{|c|}{ feasonezh } & \multicolumn{2}{|c|}{ WESKINOSKOETEN } & \multicolumn{2}{|c|}{ OVER DKACHTEN } & \multicolumn{2}{|c|}{ SCHULD. } \\
\hline & Per InW & $n x$ & Pox Ining & $x \%$ & per Inw. & In $\%$ & Per Inw. & In $\not \%$ \\
\hline nosest & & & $\therefore ?$ & $0,4_{4}$ & & & & \\
\hline $40009 \operatorname{sen} 12$ & & & - & & & & 11,76 & 0,67 \\
\hline nones -1 & & & $=$ & & & & & \\
\hline 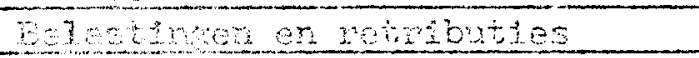 & & & - & & 0.84 & 0,16 & & \\
\hline $\cos 200$ & 8,3 & $0,2 !$ & $+6,0$ & 203 & - & - & & \\
\hline Hocose conententes & 490.25 & 2925 & 43.3 & $3: 34$ & $-1,63$ & 0,32 & $3,8,4$ & 0,22 \\
\hline 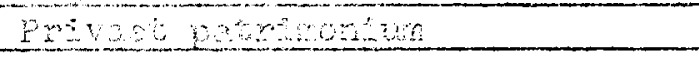 & 193,21 & $i_{1} 63$ & $i_{2} ; 9$ & 4,33 & - & - & 4,38 & 0,25 \\
\hline Aecene evenser & $-\quad-1$ & - & - & $\therefore$ & - & - & $\therefore$ & \\
\hline Tudste-801013 & 448,54 & 26,1 & 288 & 3.16 & - & - & 2,24 & 0,13 \\
\hline encose & $-\quad$ & - & 4,26 & 0,10 & 50,42 & 3,57 & - & \\
\hline 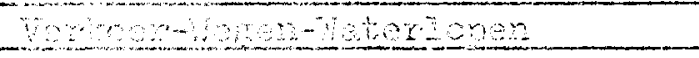 & 203.25 & 15,10 & 139.4 & $84+1$ & 0.08 & 0,02 & $66 \div, 11$ & 37,24 \\
\hline 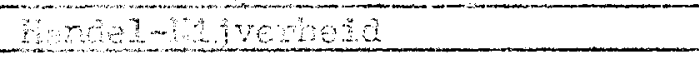 & $-\quad$ & - & 3,8 & 1,4 & 3,52 & 0,42 & $-132,14$ & 7,52 \\
\hline I. 300005 & - & - & - & - & - & & - & - \\
\hline 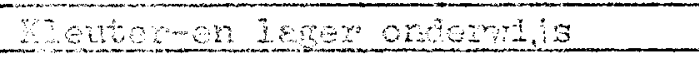 & 3,45 & 0,21 & 40,63 & 19 & - & & 39,15 & 2,23 \\
\hline 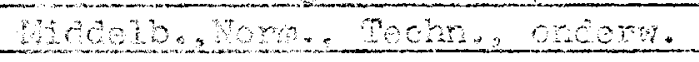 & - & - & - & - & - & & - & - \\
\hline $20 \cos 625$ & 28 & 6,4 & 2,0 & 0,35 & - & & $=$ & - \\
\hline Wotecondsste & - & - & - & - & - & & - & - \\
\hline 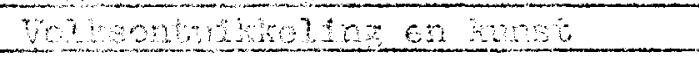 & $+52,2$ & 925 & 69,5 & 14,38 & 92,27 & 17,52 & 489,34 & 27,83 \\
\hline $\sec \cos 5$ & - & - & 54,20 & 506 & 0,84 & 0,16 & 12,52 & 1,11 \\
\hline 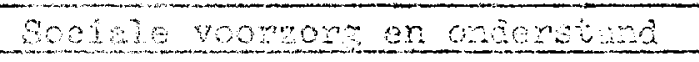 & - & - & $5: 40$ & $3: 4 c$ & 307,21 & 58,33 & 21,51 & 1,22 \\
\hline $\operatorname{sencosmo}$ & $-\quad$ & - & 3,15 & 63 & 61,42 & 11,66 & - & - \\
\hline 6006400000 & $73: 4_{4}$ & 4,3 & 19,3 & 3,23 & 2.86 & 0.54 & 2,67 & $i, 15$ \\
\hline 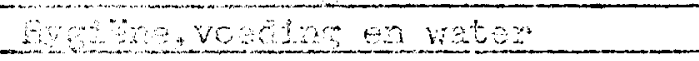 & - & - & - & - & - & - & 74.06 & 4,21 \\
\hline 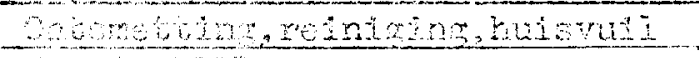 & $-0,63$ & 6,25 & 47,49 & 7,93 & 0,21 & 0,04 & 110,70 & 6,30 \\
\hline Swanks & -2 & - & $-20,00$ & 1,5 & - & - & $8+1,85$ & 4,66 \\
\hline 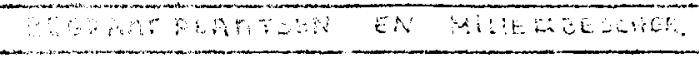 & 25,9 & 462 & $8: 43$ & 46 & 1,26 & 0,24 & 17,97 & $-1,02$ \\
\hline 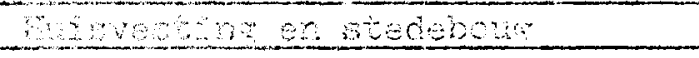 & - & & $\therefore 6$ & 545 & 5.24 & 0,96 & 79,92 & 4,54 \\
\hline Acenesh total & $1679,3,1$ & 100 & 548,47 & 100 & 526,66 & 100 & 1758,16 & 100 \\
\hline PWEDEA V.H. TCTABL. & & 36,20 & & 13,12 & & 11,54 & & 38,54 \\
\hline
\end{tabular}




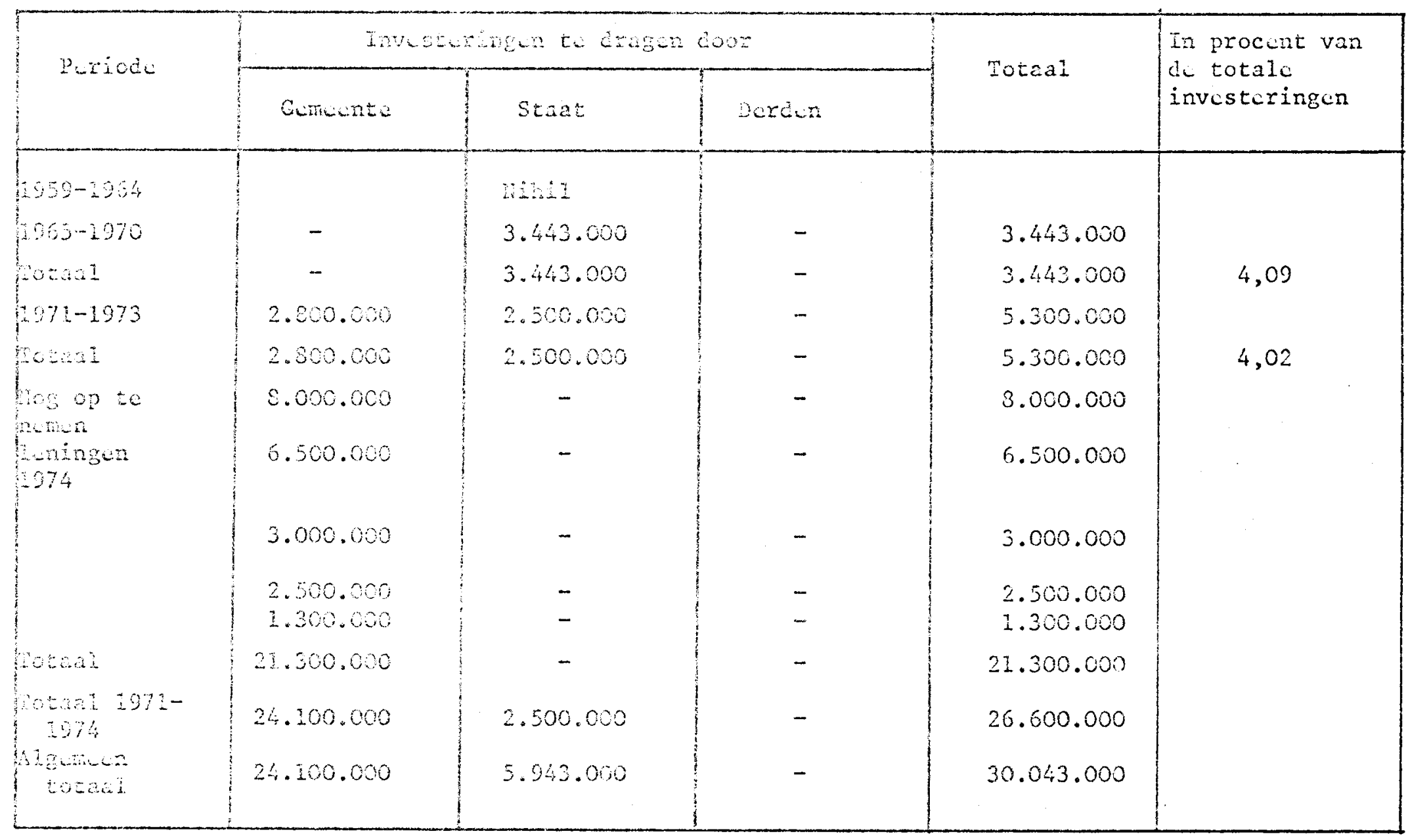

Aankoop Kesselberg

Aankoop openbaar park SAM

Aankoop gronden park

$$
\text { Michotte }
$$

Aankoop gronden spee1plcinen: voetbalveld platte-1o

Aankoop gronden voor spcclplein: Koetsweg Aankoop domein Heiberg Onteigening Kesselberg 


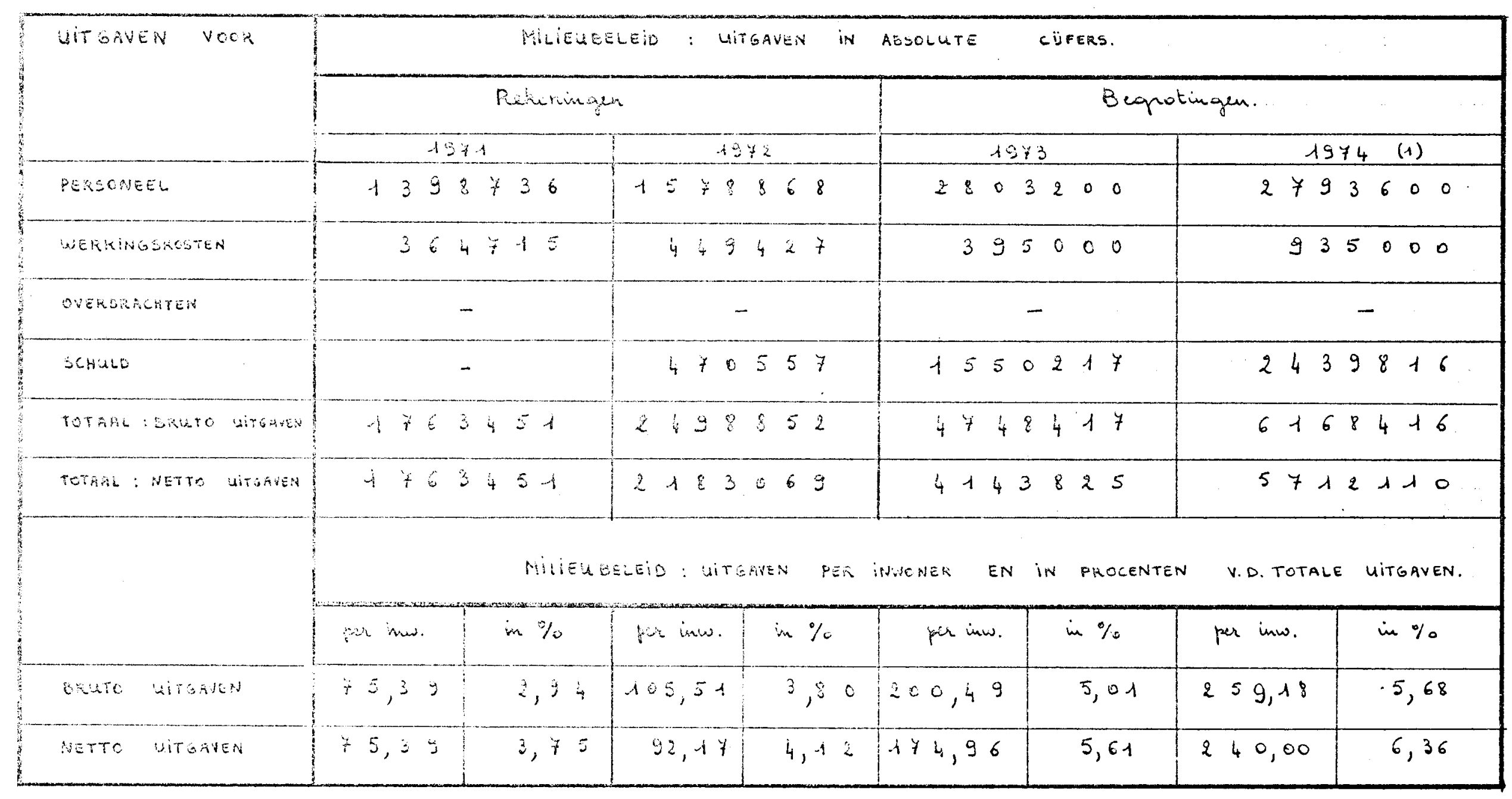

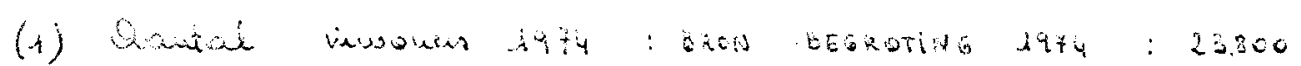

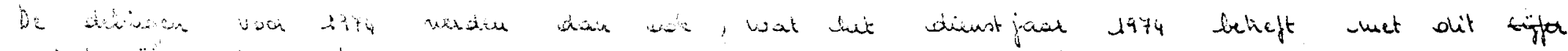

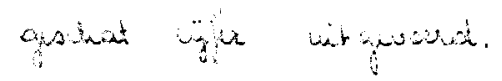




\begin{tabular}{|c|c|c|c|c|c|}
\hline \multirow{2}{*}{ Patom } & \multicolumn{3}{|c|}{ 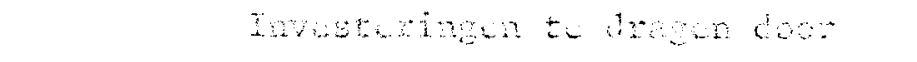 } & \multirow{2}{*}{ Sozaal. } & \multirow{2}{*}{$\begin{array}{l}\text { In procunt van } \\
\text { ic totalc } \\
\text { investuringen }\end{array}$} \\
\hline & Gorento & stat & Deran & & \\
\hline $9-9-59$ & 3.003 .000 & 1.205 .000 & - & 2.300 .000 & \\
\hline & $4: 0.070$ & - & - & $4,62.000$ & \\
\hline setas & 1.465 .000 & 1.305 .000 & - & 2.050 .000 & 18,00 \\
\hline $2065-1070$ & 333.000 & 202.000 & - & 435.000 & \\
\hline & 135.000 & 177.000 & - & 312.000 & \\
\hline $29.23 \hat{3}$ & 468.003 & 279.000 & - & 747.000 & 0,89 \\
\hline $29-2973$ & 23.562 .000 & 33.002 .000 & - & 56.944 .000 & \\
\hline & 828.000 & - & - & 820.000 & \\
\hline & 445.000 & - & - & 45.000 & \\
\hline $\operatorname{cotan} 1$ & 24.335 .000 & 3.302 .000 & - & 58.217 .000 & 44,17 \\
\hline $\log$ op to & 2.460 .000 & 1.740 .000 & - & 4.200 .000 & \\
\hline 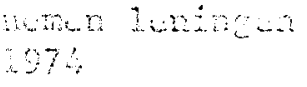 & $\begin{array}{r}3.060 .000 \\
760.000\end{array}$ & 250.000 & - & $\begin{array}{l}3.000 .000 \\
1.000 .000\end{array}$ & \\
\hline $\operatorname{cotan} i$ & 6.220 .000 & 1.980 .000 & - & 3.200 .000 & 10,49 \\
\hline 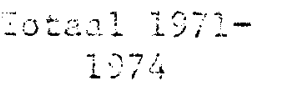 & 31.055 .000 & 35.362 .000 & - & 66.417 .000 & 31,63 \\
\hline $\begin{array}{l}\text { Bomana } \\
\text { botan? }\end{array}$ & 32.030 .000 & 37.026 .000 & - & 70.014 .000 & 22,58 \\
\hline
\end{tabular}

Afwurking: infrastructuur opunluchecuntrum Aankoop + ontciguning van gronden

Aanlog tunnisveld: openluchtcentrum

Verlichting ocfenveld: opunluchtcentrum

Oprichting zwembad on sporthal: ruwbouw

Bouwen woonhuis: sportpaviljoen

Studickoston sport- on rucruaticve uitrusting

Looppiste: atletickuitrusting Zweribad

Aanleg tennisterreinen 


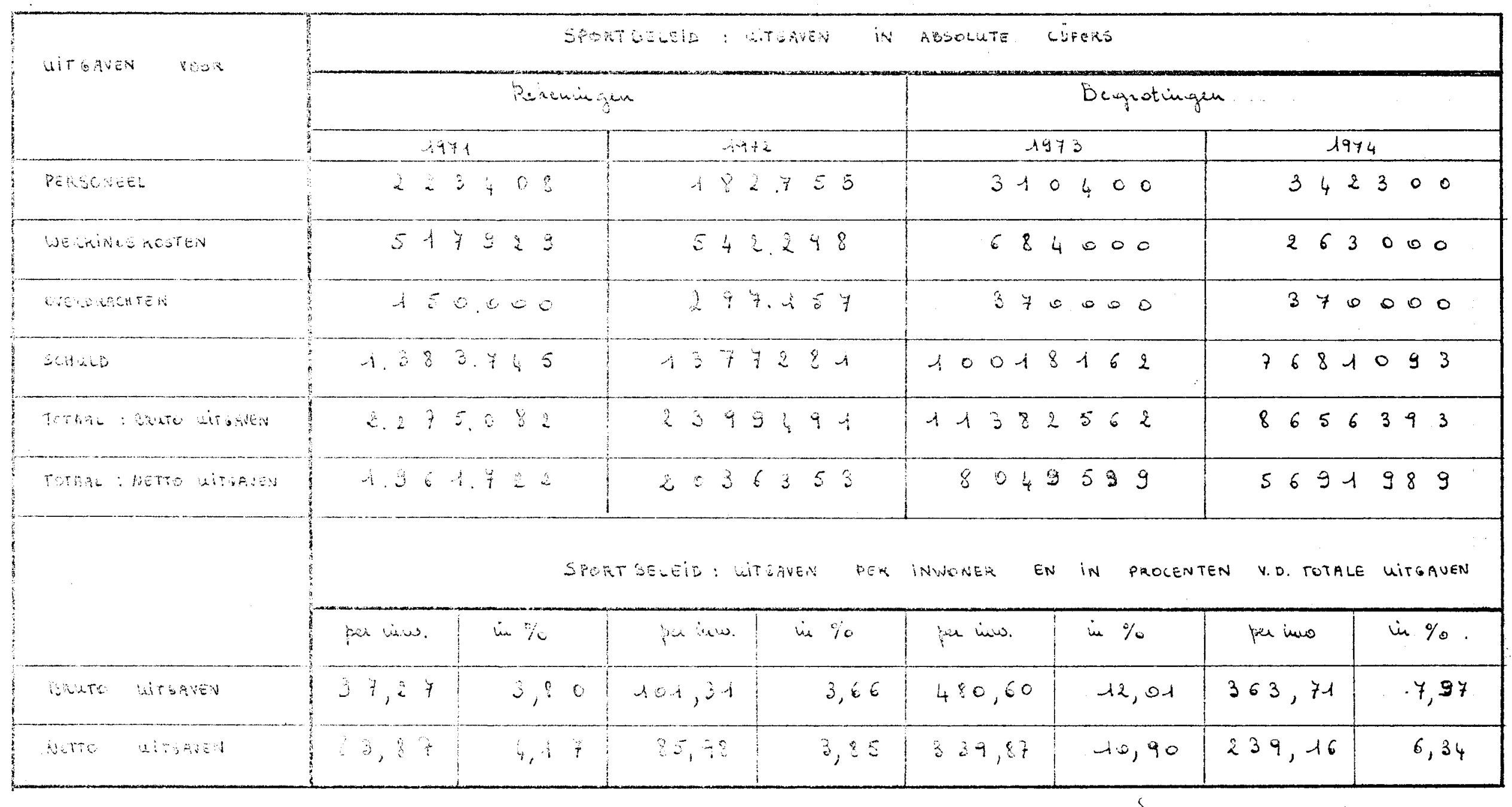




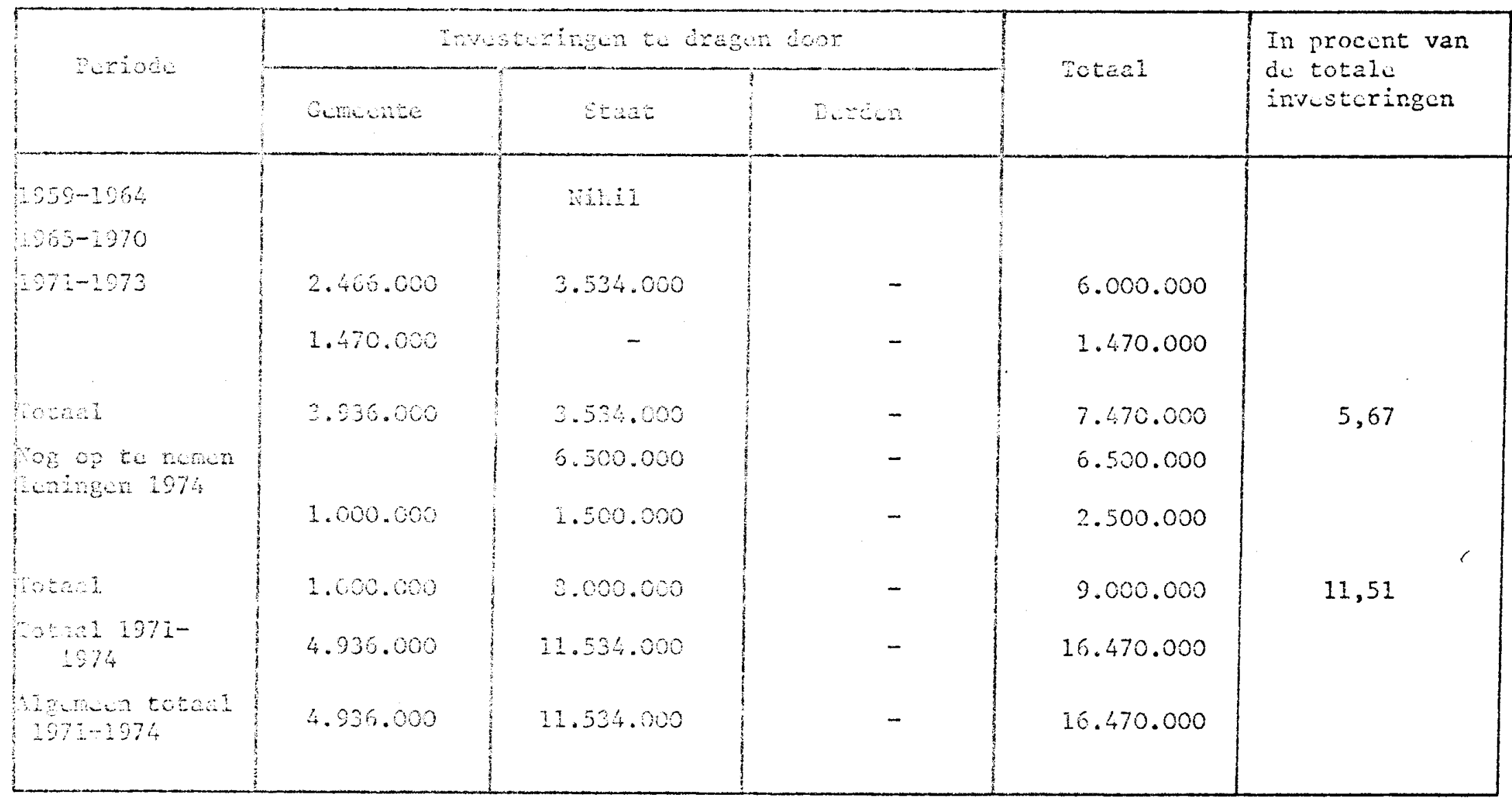

Aankoop gebouw cultureel centrum: SAM

Restauratiewerken:

Abdijhoeve

Aankoop gebouw on tuin: Heiberg

Aanpassingswerken, culturcol centrum: SAM 


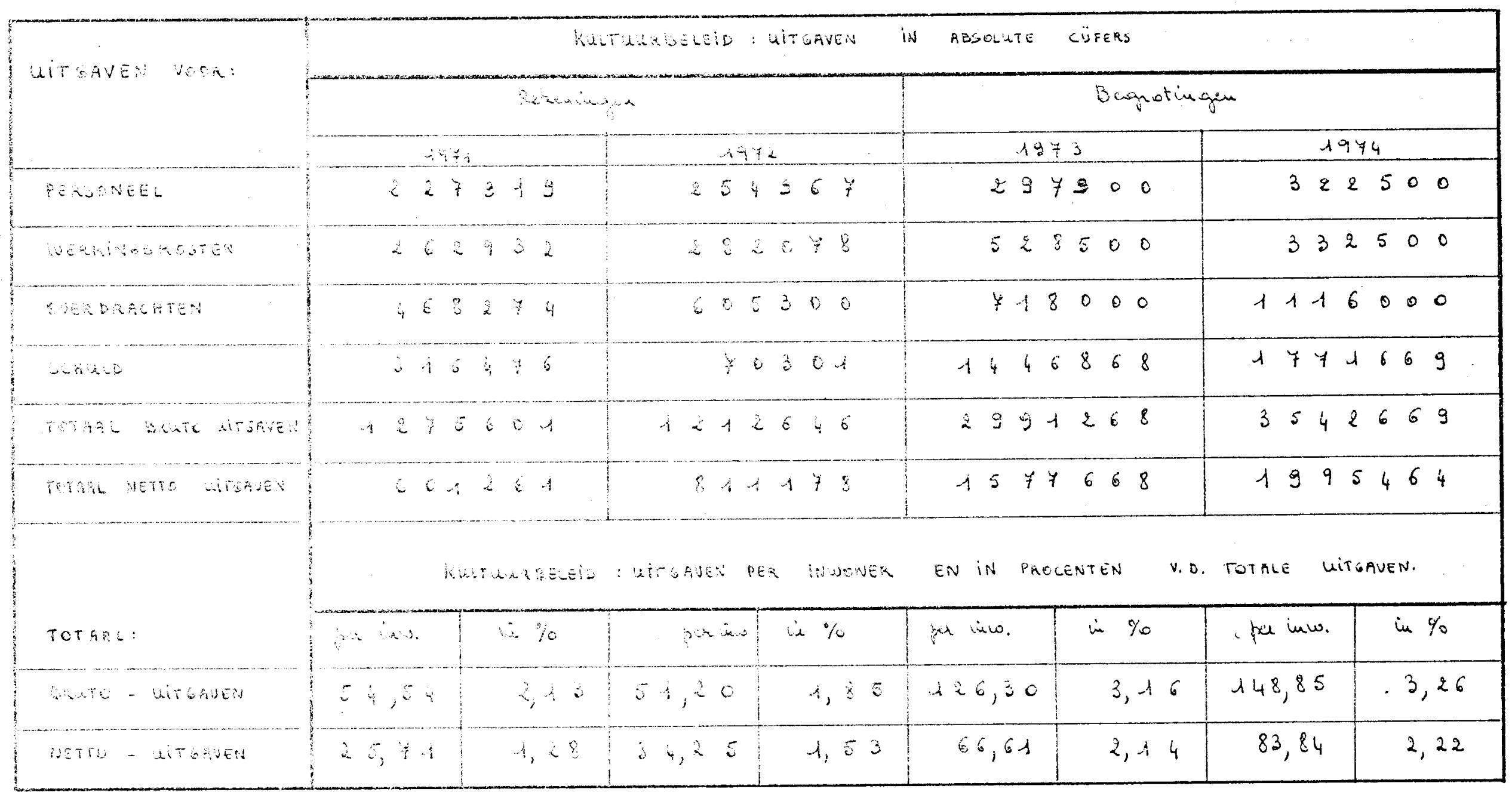




\begin{tabular}{|c|c|c|c|c|c|c|c|}
\hline \multirow{3}{*}{ WTARogn Yook: } & \multicolumn{3}{|r|}{ 3EUGEQELEL : HTSAVEN } & \multicolumn{4}{|c|}{ Absowite cürers. } \\
\hline & \multicolumn{3}{|c|}{$x^{\prime}-\mathrm{min}$} & \multicolumn{2}{|r|}{ Bugnoti } & racin & \\
\hline & \multicolumn{2}{|c|}{$\sqrt{19 y}$} & $\sqrt{492}$ & \multicolumn{2}{|c|}{1943} & \multicolumn{2}{|c|}{1974} \\
\hline Persomer & \multicolumn{2}{|c|}{-} & - & \multicolumn{2}{|c|}{-} & \multicolumn{2}{|c|}{236000} \\
\hline 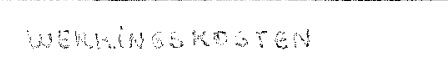 & $y$ & $93+$ & 66984 & \multicolumn{2}{|c|}{80.000} & \multicolumn{2}{|c|}{90000} \\
\hline deranguters & \multicolumn{2}{|c|}{120000} & 438742 & \multicolumn{2}{|c|}{220.000} & \multicolumn{2}{|c|}{664500} \\
\hline $3642 \mathrm{LO}$ & \multicolumn{2}{|c|}{-} & - & \multicolumn{2}{|c|}{-} & \multicolumn{2}{|c|}{-} \\
\hline 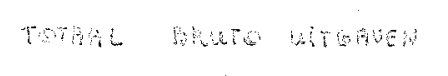 & +3 & 334 & 195726 & 30 & 000 & $97-$ & 000 \\
\hline remal wero wronded & \multicolumn{2}{|c|}{193934} & 193426 & \multicolumn{2}{|c|}{$300.000 \ldots$} & \multicolumn{2}{|c|}{971000} \\
\hline \multirow[b]{2}{*}{ Poratil: } & \multicolumn{3}{|c|}{ Jeurobeceis } & \multicolumn{4}{|c|}{ EN IN PROLENTEN U. D. TOTALE MitgRUEN. } \\
\hline & presine. & $\therefore$ & 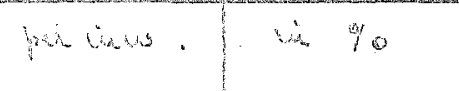 & per iniwo & in $\%$ & per inwo. & is $\%$ \\
\hline Torma buro WTEAUE & 8,29 & 0,3 & 3,26 & $12,6 y$ & 0,32 & 40,80 & 0,89 \\
\hline Temal werro wisnuen & 8,23 & 0,4 & 8,26 & $+2,67$ & 0,41 & 40,80 & 1,08 \\
\hline
\end{tabular}




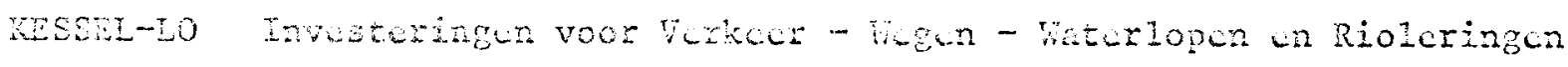

\begin{tabular}{|c|c|c|c|c|c|}
\hline \multirow{2}{*}{ Potide } & \multicolumn{3}{|c|}{ Investurineun to dragun door } & \multirow{2}{*}{ Totaal } & \multirow{2}{*}{$\begin{array}{l}\text { In procent van } \\
\text { de totale } \\
\text { investuringen }\end{array}$} \\
\hline & Gunores & stanct & Derden & & \\
\hline $1059-1064$ & 9.262 .000 & 62.000 & - & 9.324 .000 & 58,90 \\
\hline $106=-1070$ & 34.602 .000 & 17.839 .000 & - & 72.461 .000 & 86,01 \\
\hline $1971-1973$ & 48.773 .000 & 9.420 .000 & - & 58.213 .000 & 44,17 \\
\hline 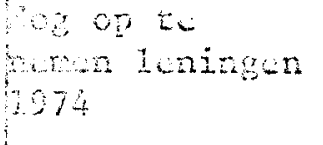 & 29.612 .250 & 687.750 & 1.000 .000 & 31.300 .000 & 40,03 \\
\hline $\begin{array}{l}6601 \\
97-1974\end{array}$ & 78.385 .250 & 10.127 .750 & 1.000 .000 & 89.513 .000 & 42,62 \\
\hline $\begin{array}{l}\text { isenter } \\
\text { cotas }\end{array}$ & 142.249 .250 & $23.02,3.750$ & 1.000 .000 & 171.298 .000 & 55,24 \\
\hline
\end{tabular}




\begin{tabular}{|c|c|c|c|c|c|}
\hline \multirow{2}{*}{ Pundede } & \multicolumn{3}{|c|}{ 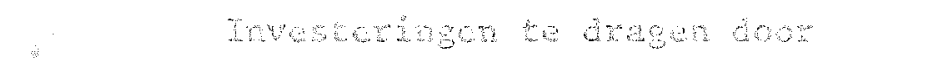 } & \multirow{2}{*}{ 2otad } & \multirow{2}{*}{$\begin{array}{l}\text { Ln procent van } \\
\text { do cotabe } \\
\text { investeringun }\end{array}$} \\
\hline & Gumento & $8 \cos t$ & $D e d a n$ & & \\
\hline $1950-1964$ & & WhHI & & & $\cdot$ \\
\hline $1965-1970$ & & & & & \\
\hline $\mid 1912-1973$ & 13.338 .990 & $\cdots$ & - & 13.335 .950 & \\
\hline & 880.000 & $\Rightarrow$ & 11. 000,000 & 11.880 .000 & \\
\hline pocesh & 24.228 .980 & - & 11.000 .000 & 25.128 .990 & \\
\hline 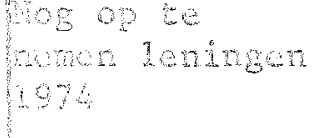 & 2.230 .000 & - & - & 2.230 .000 & \\
\hline $\operatorname{motan} 1$ & 2.200 .000 & -- & - & 2.230 .000 & \\
\hline $\begin{array}{l}\text { notas } \\
\text { som }\end{array}$ & 16.428 .900 & - & 11.000 .000 & 27.448 .990 & \\
\hline 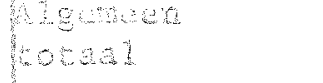 & 36.468 .090 & - & 11.000 .000 & 27.448 .990 & \\
\hline
\end{tabular}

Aankoop gronden industricterreinen: Raychem

Aankoop gronden industricterroinen:

Van der poorten

Aankoop gronden industrieterreinen: Raychem 


\begin{tabular}{|c|c|c|c|c|c|c|c|c|}
\hline \multirow{2}{*}{ Bumplos } & \multicolumn{2}{|c|}{ BELEING 1971} & \multicolumn{2}{|c|}{ BETIING no7 } & \multicolumn{2}{|c|}{ BEGEOTING 2973} & \multicolumn{2}{|c|}{ BEGROTING I974 } \\
\hline & per $1 \mathrm{mot}$ & $\operatorname{In} 9$ & per 7 hom & $\operatorname{In} \%$ & Per Ibves. & $\operatorname{In} \%$ & Per Ibus. & In $\%$ \\
\hline$A$ geneen & $-3,28$ & 8,0 & 5,0 & 0,15 & $2+1$ & 0,17 & 9,36 & 0,14 \\
\hline Alsenene sonud & $6+5$ & 2,34 & 66.8 & $\dot{d}_{2}, 8$ & 68,00 & 1,20 & 65,13 & 0,98 \\
\hline 8000801 & - & & 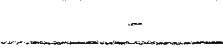 & & & $-\ldots$ & - & \\
\hline Debertimen en metwontios & 2,01 & 0,00 & 8,89 & 0,02 & 1,30 & 0,02 & 1,16 & 0,02 \\
\hline Venzelestress & 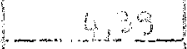 & 5,13 & 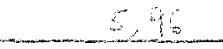 & $-3,3$ & 15.69 & 0,28 & 15,12 & 0,23 \\
\hline Alsenene acmingtretie & 322,12 & 42,9 & 3936 & 1183 & 702,83 & 12,39 & 679,23 & 10,19 \\
\hline Preyeat patrandun & 364 & 0,88 & 44,5 & $0_{1}+2$ & 16.61 & 0,29 & 16,01 & 0,24 \\
\hline Asenene disnten & 1,8 & 0,0 & 4.8 & $-2,1 L$ & 4.61 & 0,08 & -4.45 & 0,07 \\
\hline 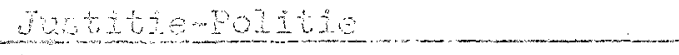 & 206,89 & 78 & 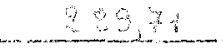 & 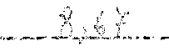 & 38238 & 6,74 & $3 Y 9,46$ & 5,69 \\
\hline exandues & 38,9 & $\cdot \sqrt{3} 38$ & $\begin{array}{r}58 \\
\end{array}$ & $8+4$ & 482 & 0,86 & 45,06 & $-0,71$ \\
\hline 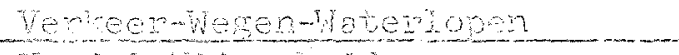 & $12+289$ & 4219 & $4398+21$ & 43.85 & 242363 & 42,14 & 242528 & $36+40$ \\
\hline 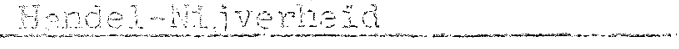 & 41286 & -38 & $-103,66$ & 328 & 120,06 & 2,12 & -10383 & $-1,56$ \\
\hline L. $90004 \mathrm{n}$ & & & & & & & - & \\
\hline 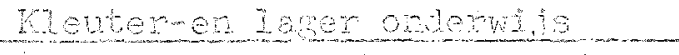 & 16736 & 3 & 480,09 & 5,39 & 347.86 & 5,60 & 358,54 & 5.38 \\
\hline 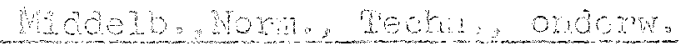 & & & & & & & & \\
\hline 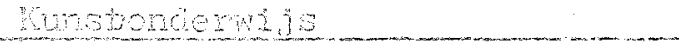 & & & & & & & & \\
\hline Loten onderyhe & 10 & 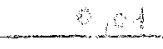 & -818 & 0,0 & 0,09 & 0,00 & 0.18 & 0,00 \\
\hline 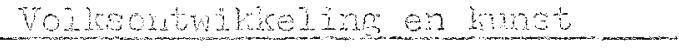 & 646 & $2+5$ & -19 & 2,68 & 499,11 & 3.80 & 1192.18 & 18,00 \\
\hline Sredisent & $-1+1,53$ & 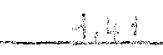 & 5023 & -2.65 & $-86,43$ & 0,99 & 65,84 & 2,99 \\
\hline Sootele rooropos on onderstend & 168.98 & 55 & $199+1$ & 5,91 & $-25 y+39$ & 45 & 328.68 & 4,84 \\
\hline 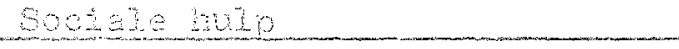 & 24.63 & -26 & 3,76 & 0.23 & $6+75$ & 1,14 & -65.36 & 1,00 \\
\hline Gezondhetdezom & 6,69 & $\theta_{3}$ & 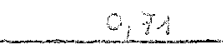 & 0,02 & -158 & 0,03 & 1,60 & 0,2 \\
\hline Hyatene poedng en water & 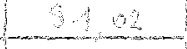 & 3.03 & 93,5 & $2+9$ & $-95,43$ & 1,10 & A01, 66 & $-1,53$ \\
\hline 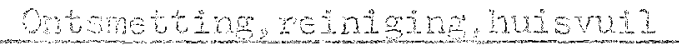 & 44,68 & $6 \cdot 1$ & $23 y+24$ & 4,13 & 177,45 & 2,13 & 300,06 & 4,50 \\
\hline 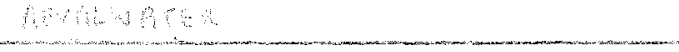 & 1213 & 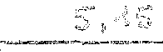 & 15932 & 1. & 258,34 & 4,56 & 272,92 & $4,-10$ \\
\hline 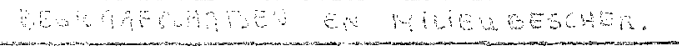 & 46,3 & 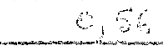 & $13,6 n$ & 0,45 & 45,36 & 0,75 & $4,+7$ & 0,72 \\
\hline Dusvesting en stedebour & 50,19 & 110 & 59,6 & $-1,19$ & $-101,6-1$ & A, 90 & 179,55 & 2,69 \\
\hline Agenes totar & $20,4,4$ & $\log _{1}, 0$ & $334,2.2$ & 100,00 & 5670,9 & 100,00 & 6662,83 & 100,00 \\
\hline & & & & & & & & \\
\hline
\end{tabular}


Areneeri

Anenene schnid

Ponesen

Bebetingen en netributies

verretreringen

MLemere eoninistratie

Privest netrinontum

Azenene diensten

Testate-poltse

Exenuees

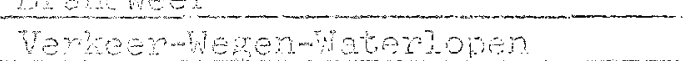

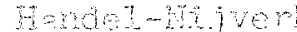

T. noboum

Leoberen zamer onjertis

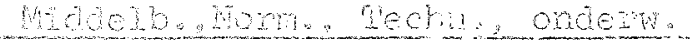
Wunsonderwis

Aoger onoming

Tolkentwheling on bunet

Predtenst

Sectale yonzorgen onderscano

ooglate nulp

Geendrezdegere

Wug-ane vedins en water

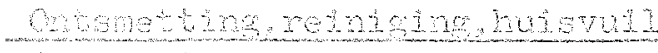

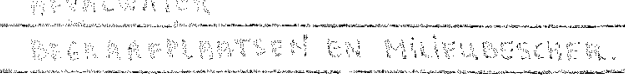

Busveatros en stedebouw

Angersen total

\begin{tabular}{|c|c|c|c|}
\hline Pow Ino & $\operatorname{In} \%$ & Per Inw & $\operatorname{In} \%$ \\
\hline$-10,4 \mathrm{~s}$ & $-0,44$ & $-29,38$ & $* \quad x, 10$ \\
\hline $61 \%$ & 2,9 & 34,55 & 35 \\
\hline
\end{tabular}

\begin{tabular}{|c|c|c|}
\hline & BEGROTING & 1973 \\
\hline $\operatorname{In} \%$ & Der Inw & $\operatorname{In} \%$ \\
\hline$=4,10$ & $-28,-42$ & $-0,58$ \\
\hline 35 & 66,96 & $-1,38$ \\
\hline- & - & - \\
\hline- & - & - \\
\hline 0,20 & 14,31 & 0,30 \\
\hline$-14,61$ & -69861 & 1442 \\
\hline
\end{tabular}

BEGROTING I974

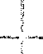

$-\infty$

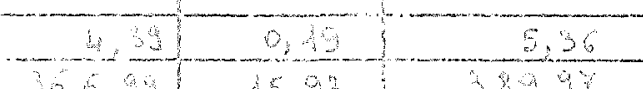

$3659+1593 \quad 3897$

$303 \quad 04045$

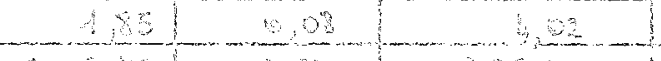

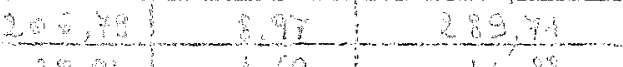

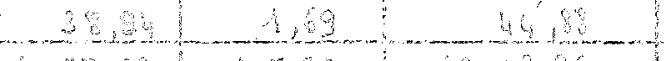
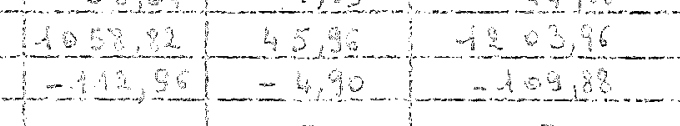

\begin{tabular}{|c|c|}
\hline Per Inw, & In $\%$ \\
\hline$-27,42$ & $-0,48$ \\
\hline 64,12 & 1,44 \\
\hline & - \\
\hline
\end{tabular}

$-\frac{0,43}{0.5}$

$-13 \pm 5$

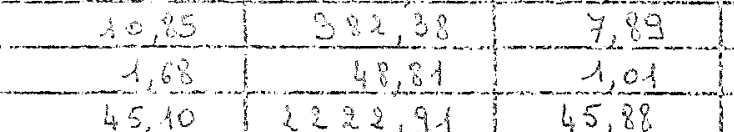

$\begin{array}{rr}45,10 & 222,91, \frac{45,88}{2} \\ -4,12 & -104,92,-2,16\end{array}$

13,79

0,25

$670,410-11,97$

$1326-\frac{97}{24}$

4,45

0,24

0,08

\begin{tabular}{|c|c|c|c|c|}
\hline 45,40 & 2222,91 & 45,88 & 2152,23 & $38+42$ \\
\hline$-4,3$ & $=104,92$ & $-2,16$ & $=109,96$ & -196 \\
\hline- & - & $-=$ & - & - \\
\hline$-8,8$ & $A^{3}+15$ & 8,57 & 18228 & 3,25 \\
\hline- & $=$ & - & $=$ & $-\ldots$ \\
\hline- & - & - & - & - \\
\hline 0,01 & 0,09 & 0,00 & 0,18 & 0,00 \\
\hline 3,35 & $-438,00$ & 9,04 & -1005.65 & 17,95 \\
\hline 2.4 & 56,43 & 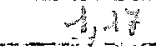 & 65,86 & $-1,18$ \\
\hline 34 & $\begin{array}{r}253 \\
-283 \\
\end{array}$ & 5,31 & 322,68 & 5,46 \\
\hline 3.04 & 6.25 & 1,30 & 66,36 & -1.18 \\
\hline 0.03 & $-1,5 x$ & 0,03 & 1,60 & 0,03 \\
\hline 0,00 & $-19,00$ & 0,00 & 1,16 & 0,02 \\
\hline 493 & $-108,22$ & 3,47 & 294,14 & 5,20 \\
\hline 5.9 & 258,33 & 5,33 & $272: 92$ & 4.87 \\
\hline$-0,+1$ & 23.85 & 0,49 & 25,9 & 0,46 \\
\hline 4,8 & 85,94 & 1,17 & 158,66 & 2,83 \\
\hline 100,00 & 485,01 & 400,00 & 5602,09 & 100,00 \\
\hline & & & & \\
\hline
\end{tabular}




\begin{tabular}{|c|c|c|c|c|}
\hline Cen Dw. & $\mathrm{Ing}$ & Pen Inam. & $\operatorname{In} \%$ & per I hw. \\
\hline$\ldots$ & - & 9.9 & 0.6 & \\
\hline- & - & $\ldots$ & - & \\
\hline- & - & $\ldots$ & - & \\
\hline- & - & - & - & 1,20 \\
\hline 5.5 & $b, 33$ & 40,45 & 0.69 & \\
\hline 46436 & 27,1 & 1446 & 130 & \\
\hline- & - & 406 & 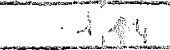 & \\
\hline$b_{6} b$ & 32 & - & $\ldots$ & \\
\hline 329,10 & $3,8,0$ & 46.29 & 3.09 & 438 \\
\hline- & - & 2.3 & $-0,16$ & 46.51 \\
\hline 5385 & 30,60 & 3915 & $47, y$ & 390 \\
\hline- & $\ldots$ & 45.8 & 095 & 0.8 \\
\hline- & - & - & - & - \\
\hline 354,4 & 9,28 & $4+46$ & 4.62 & 458 \\
\hline .... & - & - & - & \\
\hline- & - & - & - & \\
\hline- & $\ldots$ & -2 & - & 0,09 \\
\hline$\sqrt{3} 35$ & 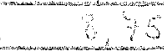 & $10,2 y$ & 3,13 & 324 \\
\hline-2 & - & -692 & 0,05 & 27,53 \\
\hline 0.68 & 0,00 & $-9,42$ & 0,05 & $256: 37$ \\
\hline- & - & 2.68 & 1,89 & 35,97 \\
\hline$\therefore$ & - & 1.11 & 0.0 & 3,46 \\
\hline- & - & 3,3 & 0.04 & \\
\hline- & $=$ & 478 & $42+1$ & 0,88 \\
\hline$\varepsilon_{0}{ }^{3}$ & - & 2861 & -136 & \\
\hline$\Delta, 6$ & 0,03 & $-18,2$ & 429 & \\
\hline- & -1 & 40 & 99 & $\sqrt{8.66}$ \\
\hline 1662,44 & 400,00 & 4563,4 & 400,00 & 446,58 \\
\hline
\end{tabular}
SCHULE.

D.eness

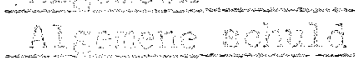

bmses

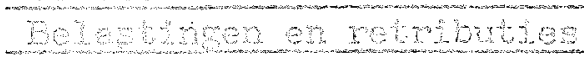

-

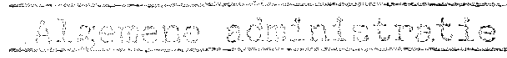

Pritest petronotren

A serene Qderatan

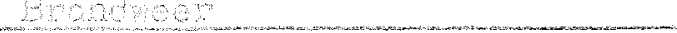

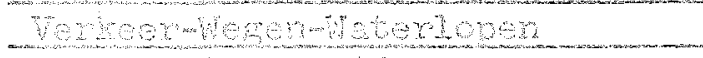

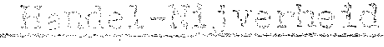

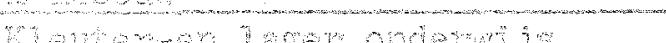

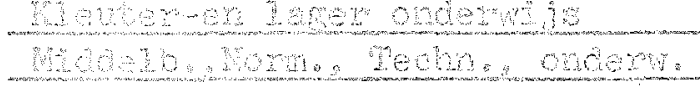

Sucsententis

Hoser coterts

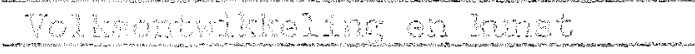
Qtesenst

Soctele poorop en moperand

501239

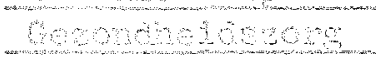

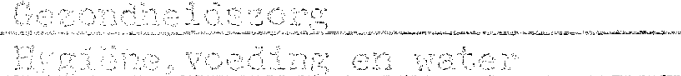

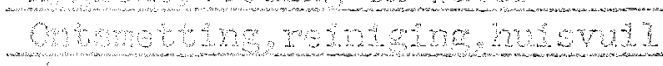

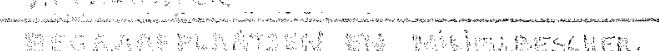

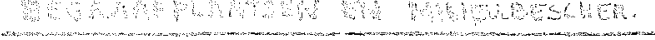

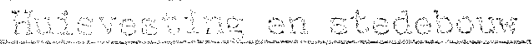
Aenocat totas

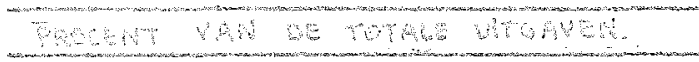
$3-81$

\begin{tabular}{|c|c|c|}
\hline $\operatorname{In} \%$ & Per Inw. & $\operatorname{In} \%$ \\
\hline & 0,02 & 0,00 \\
\hline & 68.00 & 3,24 \\
\hline \multicolumn{3}{|l|}{0,27} \\
\hline & & \\
\hline & 47,00 & 2,24 \\
\hline & & \\
\hline & & \\
\hline 0,31 & 6,68 & 0,32 \\
\hline \multicolumn{3}{|l|}{10,12} \\
\hline $0,8 Y$ & $-1162,98$ & 55,42 \\
\hline 0,06 & 105,94 & 5,05 \\
\hline 0,58 & 49,57 & 2,36 \\
\hline & & \\
\hline \multicolumn{3}{|l|}{0,62} \\
\hline 3,74 & $-136,98$ & 9,39 \\
\hline 618 & 27,92 & 1,33 \\
\hline \multicolumn{3}{|l|}{$5 y, 41$} \\
\hline \multicolumn{3}{|l|}{7,85} \\
\hline \multicolumn{3}{|l|}{0,10} \\
\hline & 36,34 & 4,59 \\
\hline \multicolumn{3}{|l|}{0,06} \\
\hline & 225,73 & $-10,95$ \\
\hline & 23,90 & 1.09 \\
\hline $4,+3$ & 34,35 & 402 \\
\hline 100,00 & 2098,49 & -100 \\
\hline 3.29 & & 3700 \\
\hline
\end{tabular}




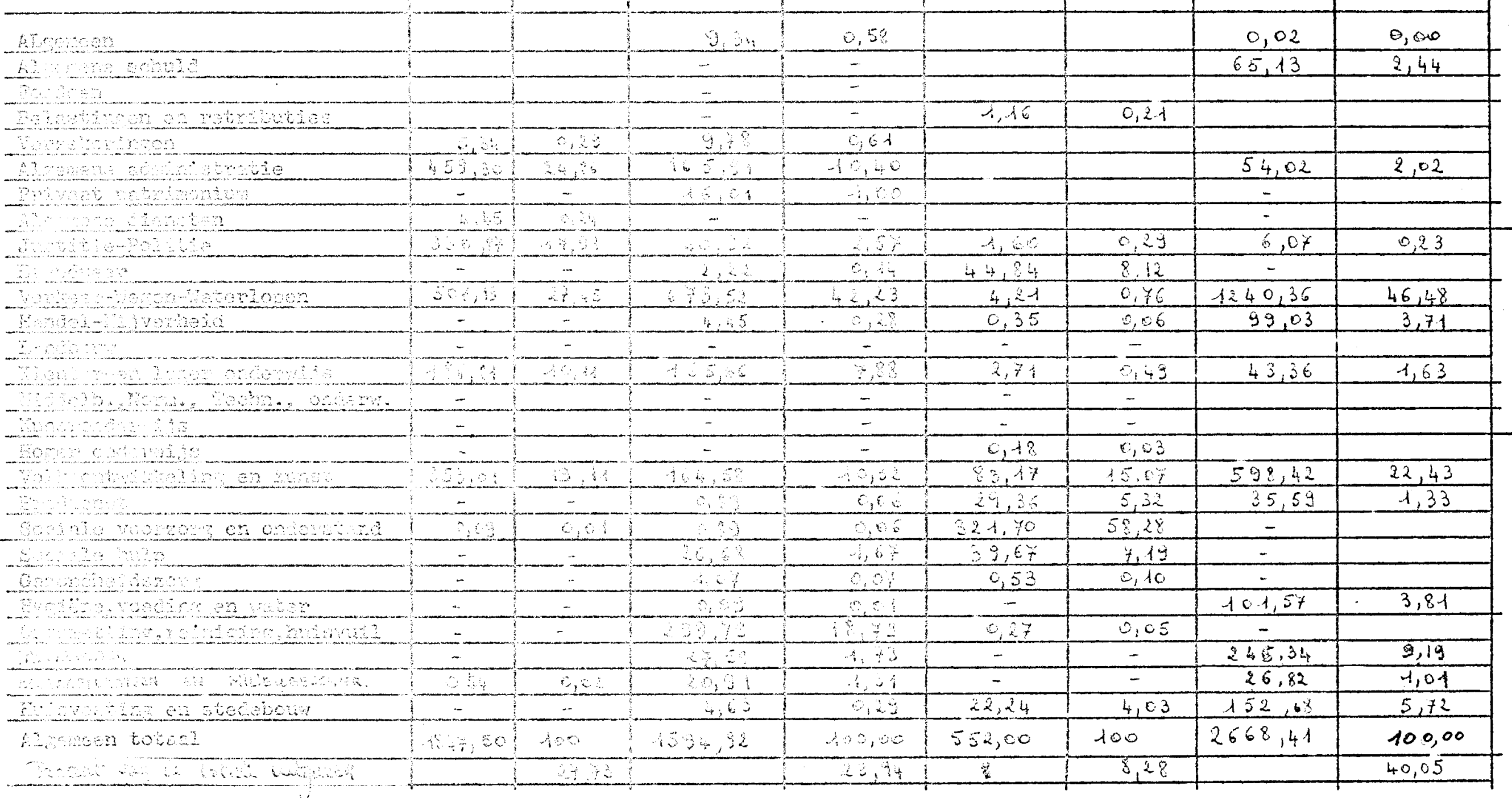




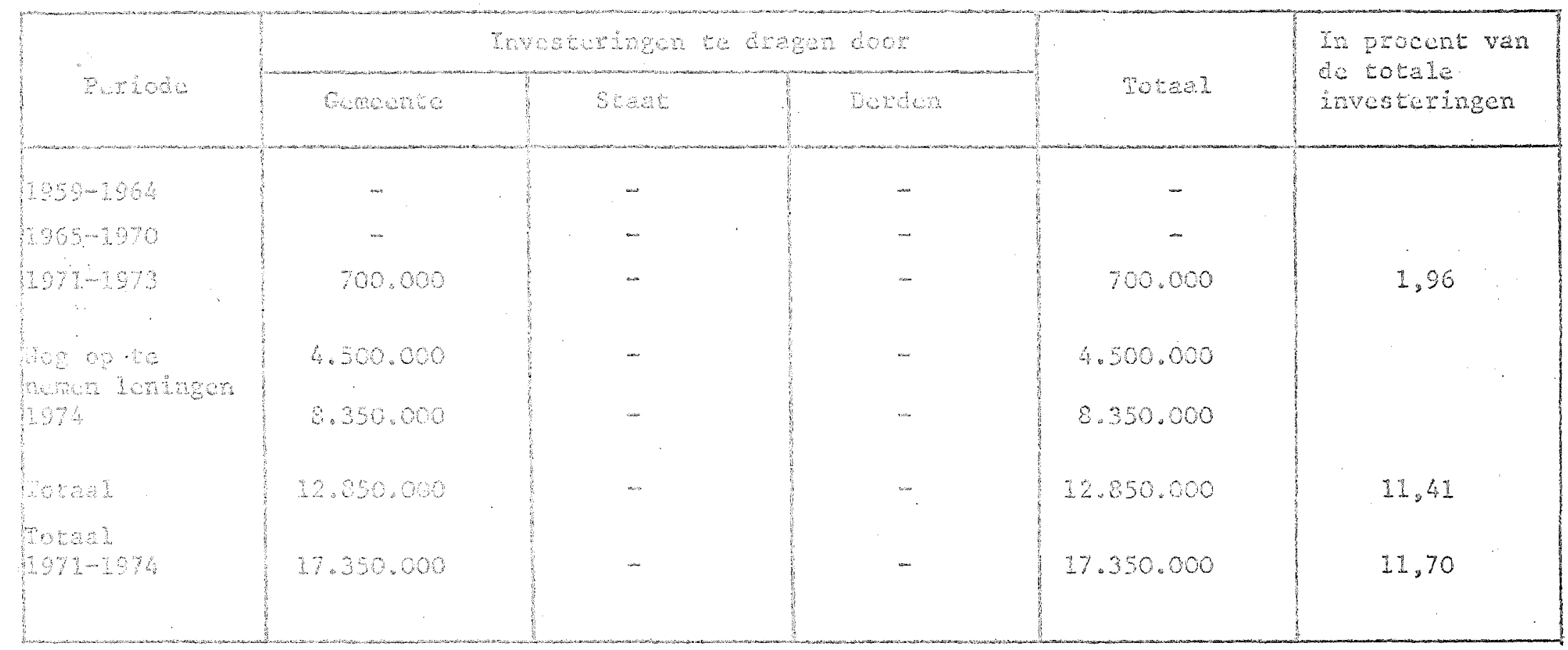

Aankoop grond on aanleg park: Rijweg

Aankoop onroerende goederen

Aanleg + crelonen parken en plantsoenen 
MHevBele id

\begin{tabular}{|c|c|c|c|c|c|c|c|c|}
\hline & \multicolumn{8}{|c|}{ aitgower in abotite cy/en } \\
\hline & \multirow{2}{*}{\multicolumn{4}{|c|}{ Rekeninger }} & \multicolumn{4}{|c|}{ Begrotingen } \\
\hline & & & & & \multicolumn{2}{|c|}{1973} & \multicolumn{2}{|c|}{1974} \\
\hline PERSONEEL & & & \multicolumn{2}{|c|}{90.000} & \multicolumn{2}{|c|}{1.076 .250} & \multicolumn{2}{|c|}{1.850 .000} \\
\hline WERKRESROSTEU & \multicolumn{2}{|c|}{34.882} & \multicolumn{2}{|c|}{248.343} & \multicolumn{2}{|c|}{250.000} & \multicolumn{2}{|c|}{500.000} \\
\hline \multicolumn{9}{|l|}{ OUERDRGHTEN } \\
\hline schuto & & & & & \multicolumn{2}{|c|}{137.400} & \multicolumn{2}{|c|}{973.776} \\
\hline 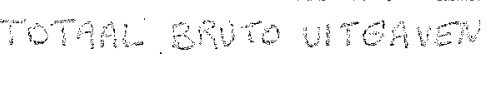 & \multicolumn{2}{|c|}{34.882} & \multicolumn{2}{|c|}{338.343} & \multicolumn{2}{|c|}{1.463 .650} & \multicolumn{2}{|c|}{3.323 .776} \\
\hline Tomm netro UTanow & \multicolumn{2}{|c|}{31.882} & \multicolumn{2}{|c|}{388.343} & \multicolumn{2}{|c|}{1.463 .650} & \multicolumn{2}{|c|}{3.323 .776} \\
\hline \multirow[b]{2}{*}{ Tothat } & \multicolumn{8}{|c|}{ 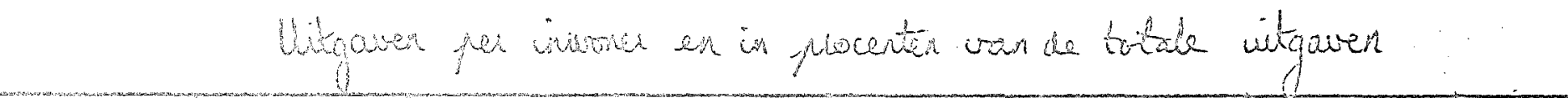 } \\
\hline & par crus. & $\therefore 2$ & mo wos. & 的范 & tere visi. & is 2 & yer inow. & $\therefore 2$ \\
\hline But we wath & 2,54 & 0,10 & 30,25 & 0,91 & 130,86 & 2.31 & 295,68 & 4,44 \\
\hline Who wighow & 2.84 & 0,13 & 30,25 & 1,43 & 430,86 & 2,70 & 295,68 & 5,28 \\
\hline
\end{tabular}




\begin{tabular}{|c|c|c|c|c|c|}
\hline \multirow{2}{*}{$\because x+0 d 0$} & \multicolumn{3}{|c|}{ anvertarino a do arsend doon } & \multirow{2}{*}{ Totas: } & \multirow{2}{*}{$\begin{array}{l}\text { In procent van } \\
\text { de total } \\
\text { investoringen }\end{array}$} \\
\hline & 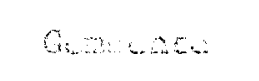 & S:C & Daran & & \\
\hline $0059-2064$ & - & - & - & - & \\
\hline $2058-2970$ & 321.000 & - & - & 321.000 & \\
\hline $9212-2973$ & 2.650 .000 & - & - & 2.650 .000 & 26,45 \\
\hline & $\begin{array}{r}45.000 \\
6.200 .000\end{array}$ & - & - & $\begin{array}{r}475.000 \\
6.300 .000\end{array}$ & \\
\hline $\operatorname{cotan}$ & 0.425 .000 & - & - & 9.425 .000 & \\
\hline 08 on 20 & 3.5 .630 .000 & 32.000 .000 & - & 30.630 .000 & \\
\hline 197 & 2.740 .000 & - & - & 2.740 .000 & \\
\hline & $3.000 \cdot 000$ & - & - & 3.000 .000 & \\
\hline $\cos 20$ & 24.370 .000 & 12.000 .000 & - & 35.370 .000 & 31,40 \\
\hline 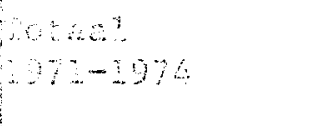 & 33.795 .000 & 12.000 .000 & - & 44.795 .000 & 30,21 \\
\hline
\end{tabular}

Erclonen sportcentrum Aankoop onrocrend gocd voor sportcomplex (Ymeria)

Aanleg tennisterrein Aankoop grond, aanleg + afwcrking zwembad

Aanlcg + creloon sportinrichtingen

Aanleg + creloon zwembad

Aankoop gronden 


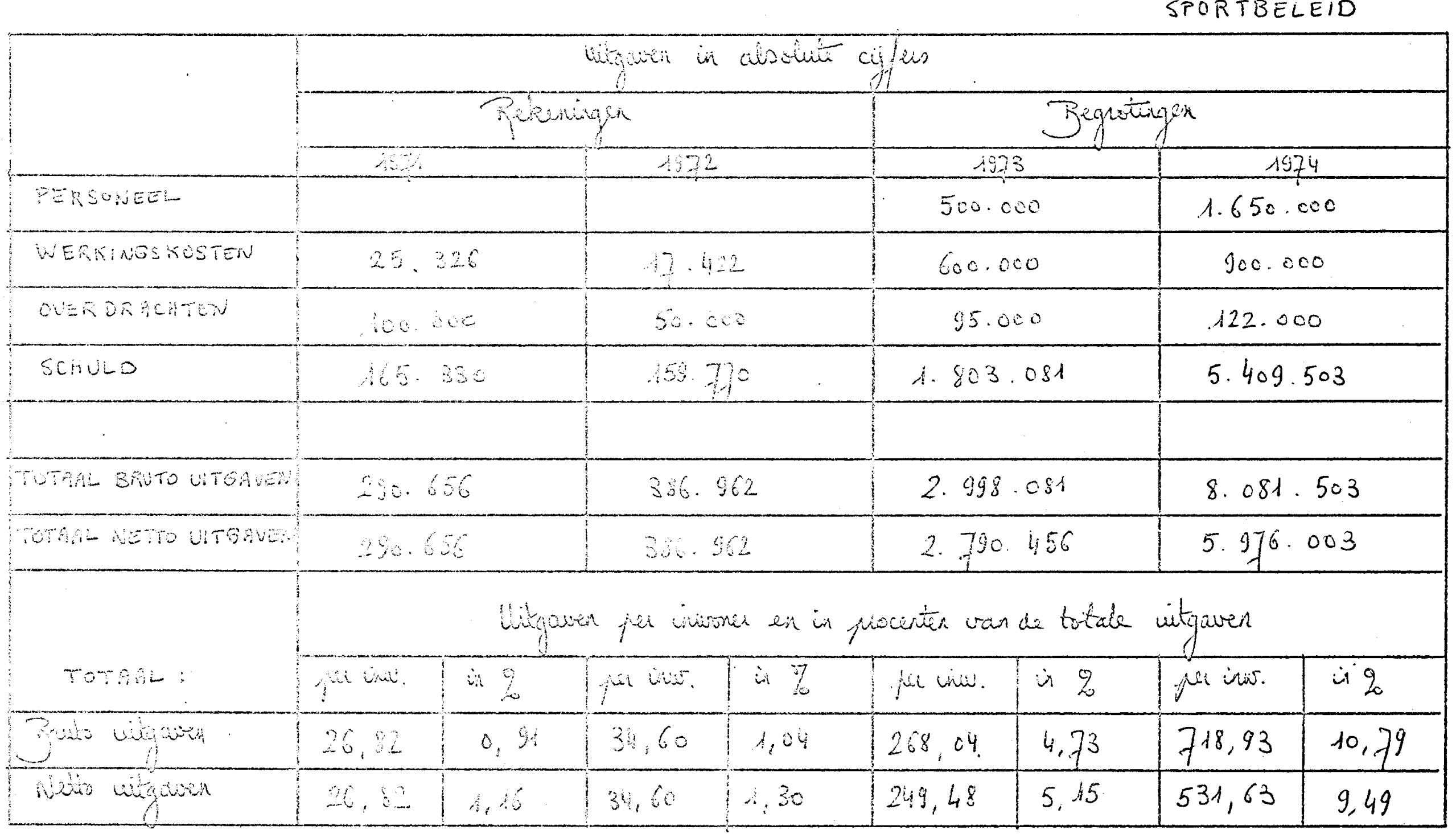




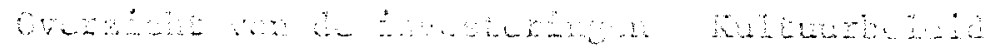

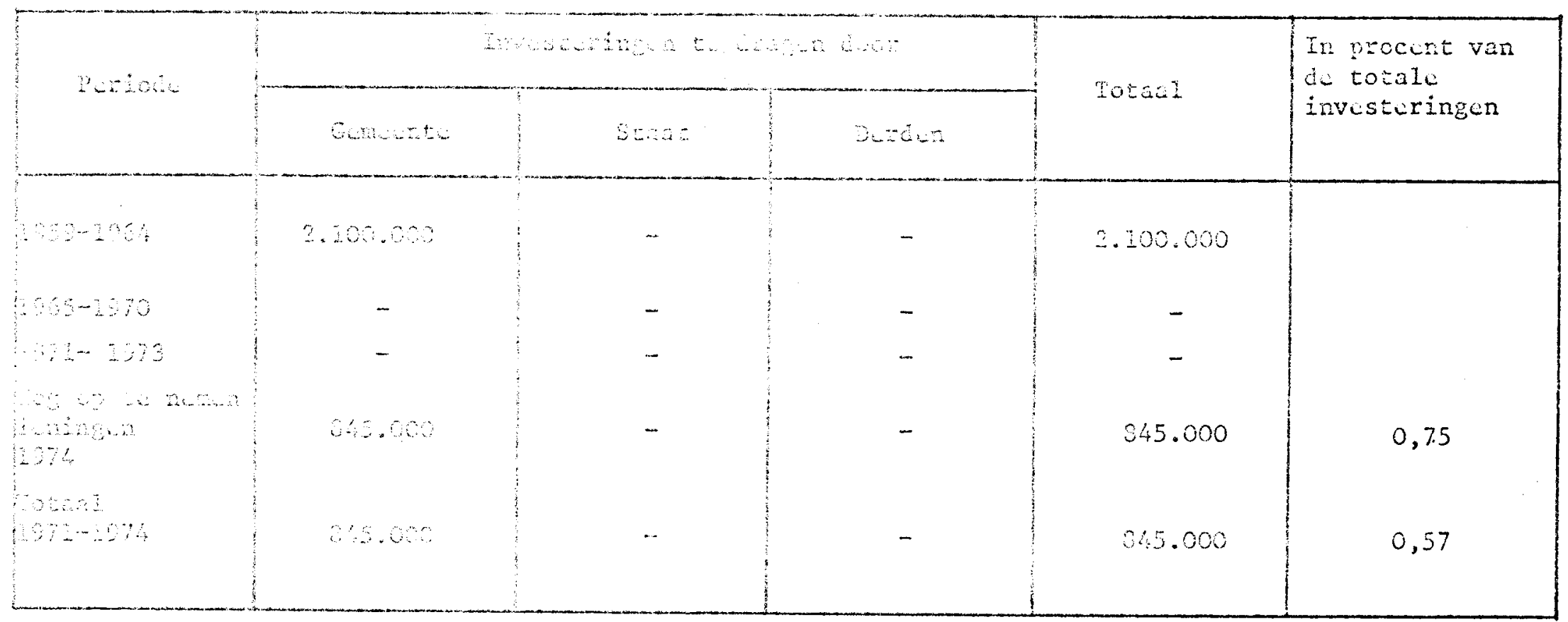

Restauratio O.L.Vr. Kerk 


\section{KULTUURBELEID}

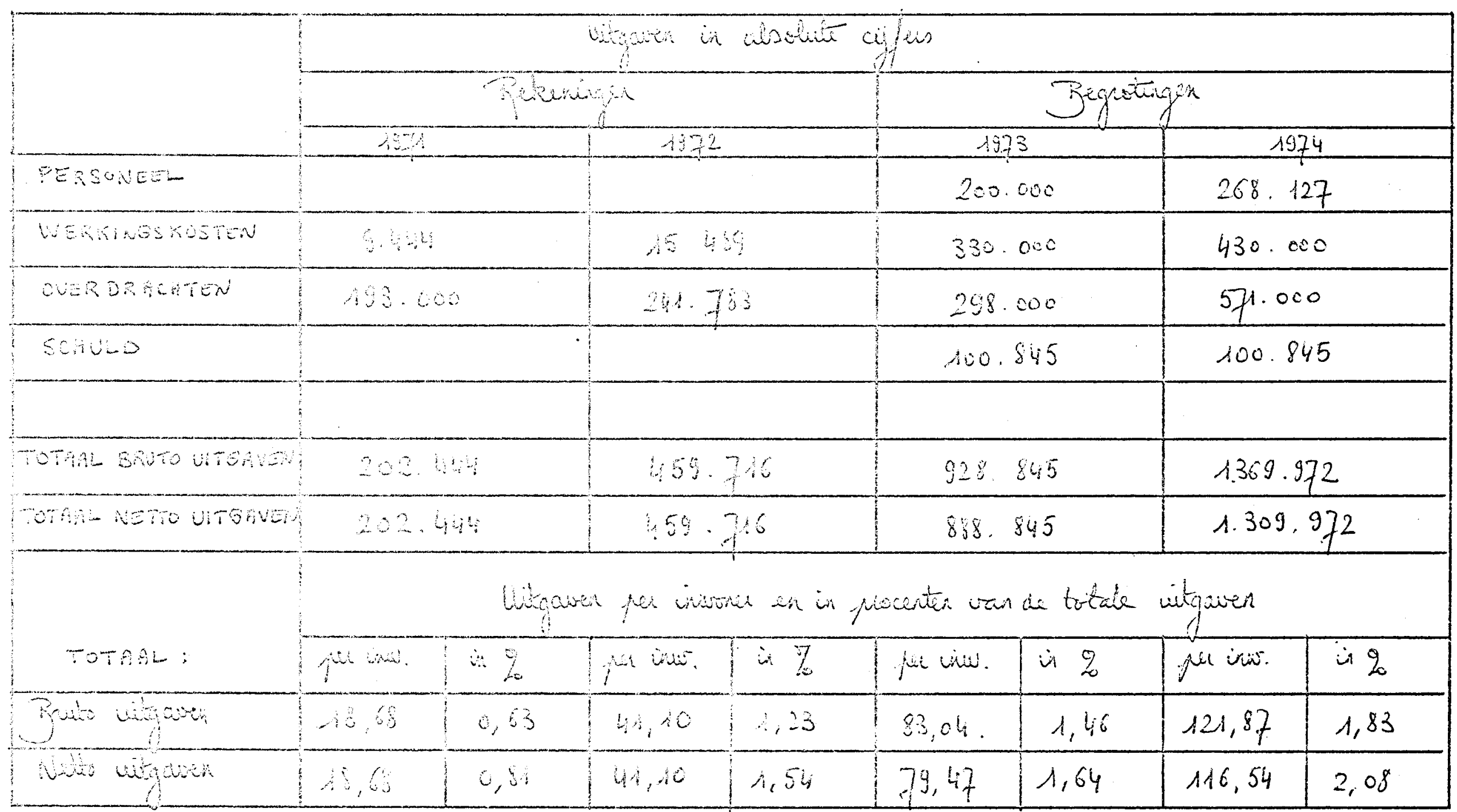




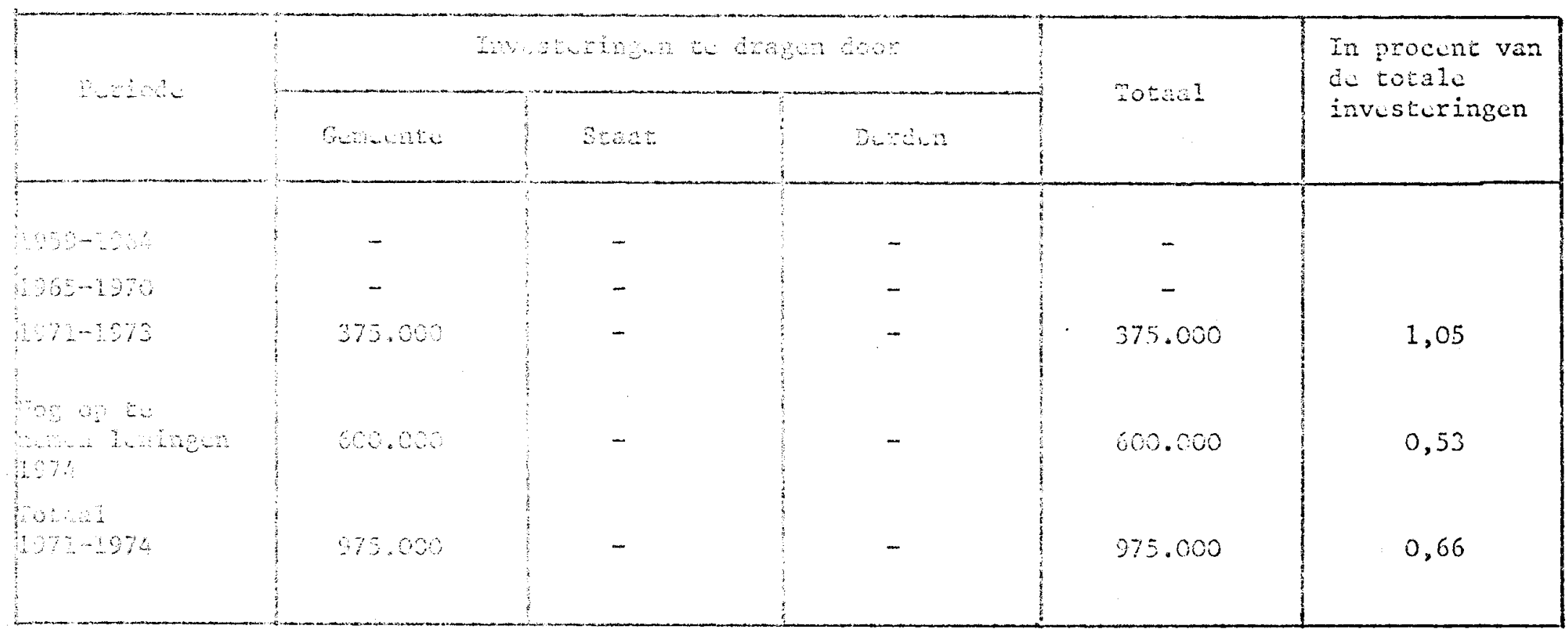

Aanleg spuelplein Rijweg

Aanleg spcelplein 
JEUGDBELEID

\begin{tabular}{|c|c|c|c|c|c|c|c|c|}
\hline & \multicolumn{8}{|c|}{ Witgaven in aibsoliti cijfess } \\
\hline & \multicolumn{4}{|c|}{ Rekeningen } & \multicolumn{4}{|c|}{ Begrotingen } \\
\hline & \multirow{2}{*}{\multicolumn{2}{|c|}{1971}} & \multicolumn{2}{|c|}{1972} & \multicolumn{2}{|c|}{1973} & \multicolumn{2}{|c|}{1974} \\
\hline \multicolumn{7}{|l|}{ PERSUNEEL } & & \\
\hline WERKINGS KOSTEN & \multicolumn{2}{|c|}{19.999} & \multicolumn{2}{|c|}{20.000} & \multicolumn{2}{|c|}{20.000} & \multicolumn{2}{|c|}{20.000} \\
\hline OVER DRALHTEN & \multicolumn{2}{|c|}{87.000} & \multicolumn{2}{|c|}{$60 \cdot 000$} & \multicolumn{2}{|c|}{$100 \cdot 000$} & \multicolumn{2}{|c|}{322.000} \\
\hline SCHULD & & & & & \multicolumn{2}{|c|}{93.375} & \multicolumn{2}{|c|}{242.775} \\
\hline TOTAAL BRUTO UITGAVEN & \multicolumn{2}{|c|}{106.999} & \multicolumn{2}{|c|}{80.000} & \multicolumn{2}{|c|}{213.375} & \multicolumn{2}{|c|}{$584.77^{5}$} \\
\hline TOTARL NETTO UITGAVEM & \multicolumn{2}{|c|}{106.999} & \multicolumn{2}{|c|}{80.000} & \multicolumn{2}{|c|}{213.375} & \multicolumn{2}{|c|}{584.775} \\
\hline \multirow[b]{2}{*}{ TOTAAL: } & \multicolumn{8}{|c|}{ Witgaven per viswores en in plocenten van de totale uitgaven } \\
\hline & per ins. & $\therefore 2$ & psi vines. & is $\%$ & per wilus. & $\dot{u} \%$ & per inis. & $\ddot{4} 2$ \\
\hline Bruto vitgaved & 9,87 & 0,34 & 7,15 & 0,21 & 19,08 & 0,34 & 52,02 & 0,78 \\
\hline Netto witg duren & 9,87 & 0,43 & 7.15 & 0,27 & 19,08 & 0,39 & 52,02 & 0,93 \\
\hline
\end{tabular}


HERENT Overzicht der investeringen: Vorkecr, Wegen, Watcrlopen en Rioleringen

\begin{tabular}{|c|c|c|c|c|c|}
\hline \multirow{2}{*}{ Puriode } & \multicolumn{3}{|c|}{ Investeringen te dragen door } & \multirow{2}{*}{ Totaal } & \multirow{2}{*}{$\begin{array}{l}\text { In procent van } \\
\text { de totale } \\
\text { investeringen }\end{array}$} \\
\hline & Gumicnte & Staat & Durden & & \\
\hline $1959-1964$ & 53.919 .000 & 16.398 .000 & - & 70.317 .000 & 76,51 \\
\hline $1965-1970$ & 9.481 .000 & - & - & 9.431 .000 & 64,67 \\
\hline 1971-1973 & 18.462 .000 & 5.505 .000 & - & 23.967 .000 & 67,26 \\
\hline $\begin{array}{l}\text { Nog op te } \\
\text { nemun leningen } \\
1974\end{array}$ & 33.011 .000 & 8.775 .000 & - & 41.786 .000 & 37,09 \\
\hline $\begin{array}{l}\text { Totaal } \\
1971-1974\end{array}$ & 51.473 .000 & 14.280 .000 & - & 65.753 .000 & 44,34 \\
\hline $\begin{array}{l}\text { Algemeen } \\
\text { totaal }\end{array}$ & 114.873 .000 & 30.678 .000 & - & 145.551 .000 & 57,11 \\
\hline
\end{tabular}

